DOUGLAS POLCARO NEGRÃO

\title{
ESTUDO DE ASFALTOS MODIFICADOS POR POLÍMEROS DO TIPO RET PARA APLICAÇÕES EM PAVIMENTOS
}

Dissertação apresentada à Escola Politécnica da Universidade de São Paulo para obtenção do Título de Mestre em Engenharia.

São Paulo

2006 


\section{DOUGLAS POLCARO NEGRÃO}

\section{EstUdo DE Asfaltos Modificados POR POLÍMEROS DO TIPO RET PARA APLICAÇÕES EM PAVIMENTOS}

Dissertação apresentada à Escola Politécnica da Universidade de São Paulo para obtenção do Título de Mestre em Engenharia.

Área de Concentração:

Engenharia de Transporte

Orientadora:

Profa. Dra. Liedi Légi Bariani. Bernucci

São Paulo

2006 


\section{FICHA CATALOGRÁFICA}

\section{Negrão, Douglas Polcaro}

Estudo de asfaltos modificados por polímeros do tipo RET para aplicações em pavimentos I D.P. Negrão. -- São Paulo, 2006.

$160 \mathrm{p}$.

Dissertação (Mestrado) - Escola Politécnica da Universidade de São Paulo. Departamento de Engenharia de Transportes.

1.Asfalto 2.Asfalto modificado por polímeros 3.Polímero RET I.Universidade de São Paulo. Escola Politécnica. Departamento de Engenharia de Transportes II.t. 
DEDICATÓRIA

A Andrea, paixão da minha vida, esposa amada e companheira. Aos meus pais, exemplo de vida e de companheirismo. Aos meus irmãos Adriano e Humberto. 


\section{AGRADECIMENTOS}

À Profa. Dra. Liedi Légi Bariani Bernucci pela confiança, orientação e tranqüilidade transmitidas sempre ao longo deste trabalho.

Aos professores do Curso de Pós-Graduação da Escola Politécnica da Universidade de São Paulo, pelos ensinamentos transmitidos e ao Edson Moura, pela ajuda imprescindível na realização dos ensaios.

À concessionária Autoban e a Engelog, que possibilitaram o desenvolvimento do estudo de caso, em especial à Engenheira Paula Moreira e ao Sr. Sales, pela complementação do banco de dados com informações preciosas relativas ao projeto e execução das obras.

Ao Dr. Ernesto Simões Preussler, pelo apoio e confiança depositados em mim ao longo destes quase dez anos de trabalho em conjunto.

Aos amigos da Dynatest que sempre me incentivaram, em especial ao André Felipe Vale, por ter ajudado a tornar este trabalho em realidade.

Aos amigos da DuPont, em especial ao Sr. Marcos Cantharino, à Sra. Florência Canale, ao Sr. Silvério Giesteira ao Sr. Marcelo Borges e a Sra. Maria Amelia Cerino. 


\section{RESUMO}

O presente trabalho avalia as alterações de propriedades dos asfaltos pela modificação por polímero do tipo RET (Reactive Elastomeric Terpolymer) e de comportamento de misturas asfálticas densas usinadas com estes asfaltos modificados. Para atingir este objetivo, são apresentados os resultados do monitoramento realizado no trecho experimental executado na SP-330, Rodovia Anhanguera, que empregou este tipo de asfalto modificado e estudo que compreende a modificação de ligantes do tipo CAP20 e CAP40 com $1,0 \%, 1,5 \%$ e $2 \%$, de polímero RET, com posterior dosagem de uma mistura na Faixa III do DERSA no teor considerado como o mais adequado. Para verificação das propriedades mecânicas desta mistura, foram realizados ensaios de Módulo se Resiliência, Resistência à Tração por Compressão Diametral e Resistência à Deformação Permanente em simulador do tipo LPC. 


\begin{abstract}
The present document presents the alterations of the properties of the polymer modified asphalts using the polymer RET (Reactive Elastomeric Terpolymer) and the behavior of dense asphaltic mixtures using these modified asphalts. To reach this objective, the monitoring results accomplished in the experimental tram executed in SP-330, Rodovia Anhanguera, that used this type of modified asphalt are presented. The study comprehends the modification of the CAP20 and CAP40 asphalts with $1,0 \%, 1,5 \%$ and $2,0 \%$ of RET polymer, with subsequent dosage of a mixture in the Grade III of DERSA applying the RET polymeric proportion considered more appropriate. For the verification of the mechanical properties of this mixtures, Resilience Module, Traction Resistance for Diametrical Compression and Permanent Deformation Resistance in a LPC type simulator were accomplished.
\end{abstract}




\section{SUMÁRIO}

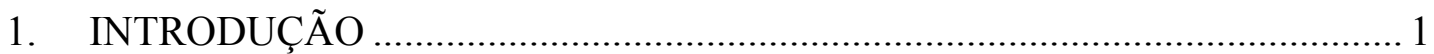

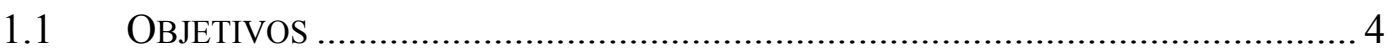

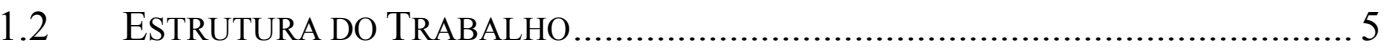

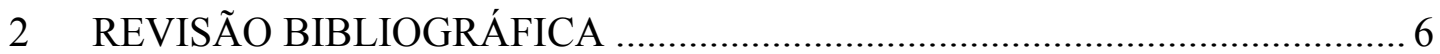

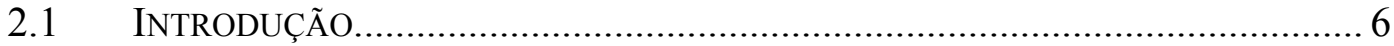

2.2 ASFALTO

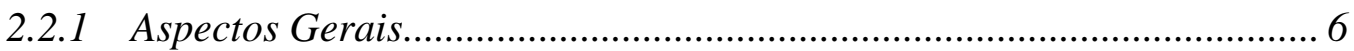

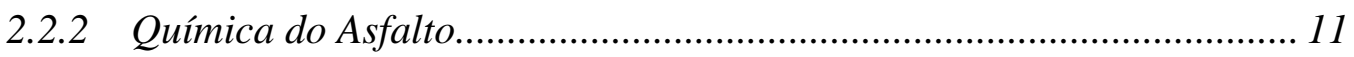

2.2.3 Reologia dos Asfaltos e Ensaios Reológicos........................................... 16

2.3 Polímeros ModificAdores de ASFALTO ................................................. 26

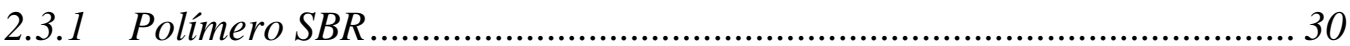

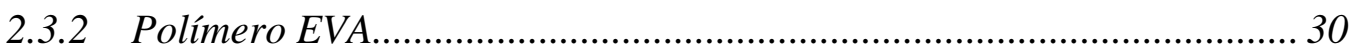

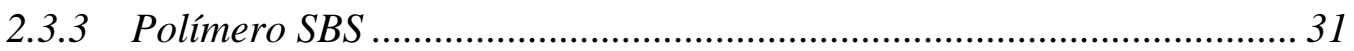

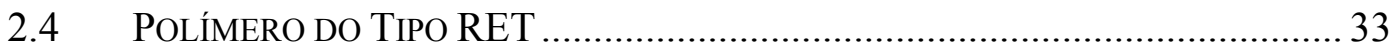

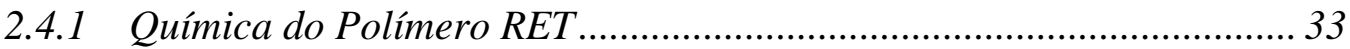

2.4.2 Características dos Asfaltos Modificados por Polímero do Tipo RET.. 35

2.4.3 Processo de Modificação do Asfalto com o Polímero do Tipo RET...... 36

2.4.4 Estudo da Federal Highway Administration com o Polímero RET........ 38

2.4.5 Experiências do Polímero do Tipo RET no Brasil.................................. 40

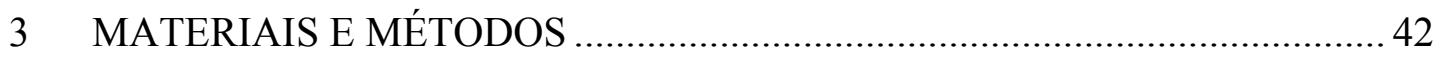

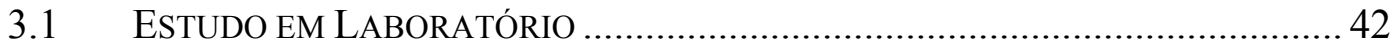




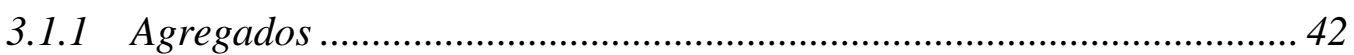

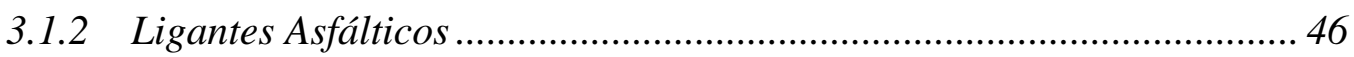

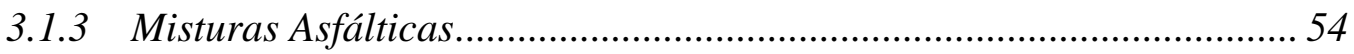

3.2 TRECHO EXPERIMENTAL DA Rodovia ANHENGUERA ................................ 60

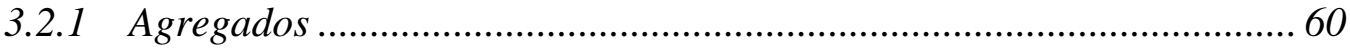

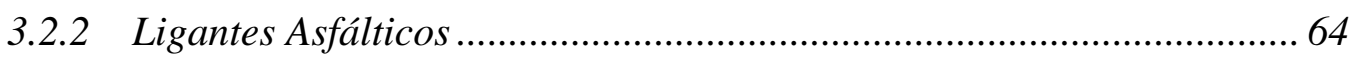

3.2.3 Monitoramento do Trecho Experimental .............................................. 65

$4 \quad$ ESTUDO DE CASO EM LABORATÓRIO …................................................. 78

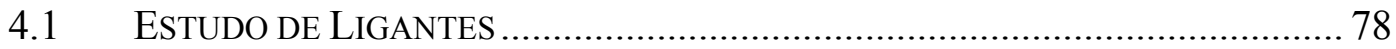

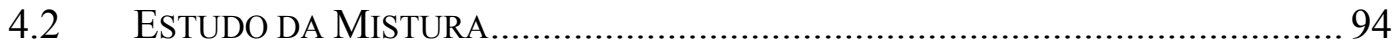

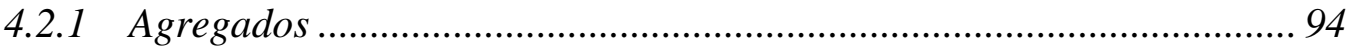

4.2.2 Granulometria de Dosagem dos Agregados ......................................... 95

4.2.3 Determinação do Teor Ótimo de Ligante Asfáltico ............................... 95

4.2.4 Temperaturas de Usinagem e Compactação ........................................ 104

4.2.5 Desempenho das Misturas Asfálticas ................................................ 104

5 ESTUDO DE CASO: TRECHO EXP. DA VIA ANHANGUERA ................. 111

5.1 CONDIÇÕES ORIGINAIS DO SEGMENTO................................................. 112

5.1.1 Geometria Histórico e Estrutura ......................................................... 112

5.1.2 Condição do Pavimento .................................................................... 113

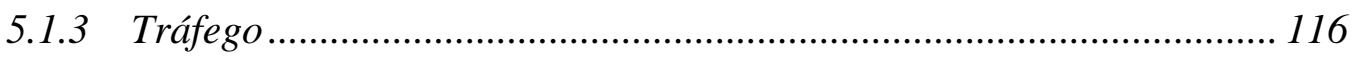

5.1.4 Análise Estrutural .......................................................................... 118

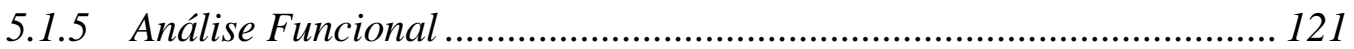

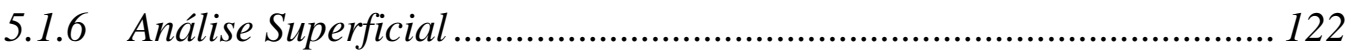


5.1.7 Soluções de Restauração Adotadas 123

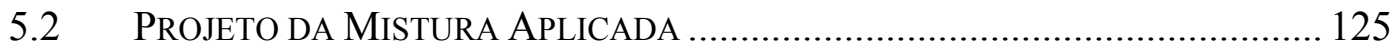

5.3 EXECUÇÃo E Controle de Qualidade da OBRA .................................. 127

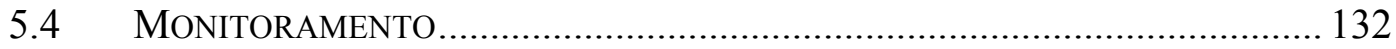

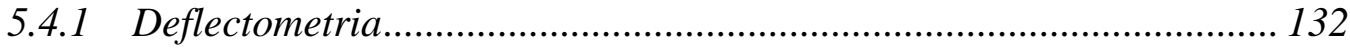

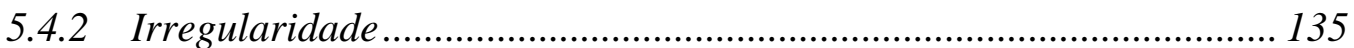

5.4.3 Inventário de Superfície .................................................................. 138

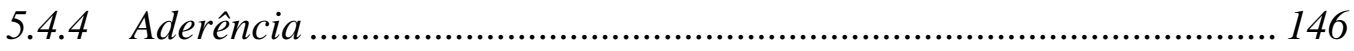

6 CONCLUSÕES E RECOMENDAÇÕES ..................................................... 148

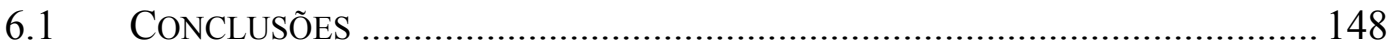

6.1.1 Estudo de Ligantes em Laboratório..................................................... 148

6.1.2 Estudo de Mistura Asfáltica em Laboratório....................................... 149

6.1.3 Estudo do Trecho Experimental....................................................... 150

6.2 RECOMENDAÇÕES E SUGESTÕES DE CONTINUIDADE DE PESQUISA............... 151 


\section{LISTA DE TABELAS}

Tabela 1.1 - A matriz de transporte do Brasil (Geipot, 2000)

Tabela 2.1 - Configuração dos polímeros

Tabela 2.2 - Segmentos Executados com Polímero do Tipo RET

Tabela 3.1 - Análise Granulométrica dos Agregados

Tabela 3.2: Características do Agregado Estudado

Tabela 3.3 - Analise Granulométrica dos Agregados

Tabela 3.4 - Especificações para Cimento Asfáltico de Petróleo - CAP

Tabela 3.5 - Análise Granulométrica dos Agregados

Tabela 3.6: Características do Agregado Estudado

Tabela 3.7 - Distribuição percentual dos agregados e curva de projeto

Tabela 3.8 - Classificação da condição da via a partir dos valores de VRD

Tabela 3.9 - Classificação da condição da via a partir da profundidade de areia

Tabela 4.1 - Ponto de Fulgor dos Ligantes Ensaiados

Tabela 4.2 - Viscosidade BrookField para diferentes Temperaturas (CAP20)

Tabela 4.3 - Viscosidade Brookfield para diferentes Temperaturas (CAP40)

Tabela 4.4 - Densidades dos Ligantes Estudados

Tabela 4.5 - Escolha do Tipo de Ligantes - Ensaios Realizados

Tabela 4.6: Características do Agregado Estudado

Tabela 4.7: Composição Granulométrica

Tabela 4.8 - Resumo do Projeto de Mistura para o CAP20+1,5\%RET $+0,22 \%$ CAT

Tabela 4.9 - Comparativo dos Resultados (CAP20+1,5\%RET+0,22\%CATxCAP20)

Tabela 4.10 - Resumo do Projeto de Mistura para o CAP40+1\%RET $+0,22 \% \mathrm{CAT}$ 
Tabela 4.11 - Comparativo dos Resultados (CAP40+1\%RET+0,22\%CATxCAP40)

Tabela 4.12 - Temperaturas de usinagem e compactação

Tabela 4.13 - Resultados Médios dos Ensaios de Módulo de Resiliência encontrados

Tabela 4.14 - Resultados Médios dos Ensaios de Resistência à Tração

Tabela 4.15 - Resultados do Ensaio de Deformação Permanente em Simulador LPC

Tabela 5.1 - Dados de deflexão do Projeto de Restauração (Faixa Externa)

Tabela 5.2 - Resumo dos defeitos cadastrados

Tabela 5.3 - VDM do Projeto Original

Tabela 5.4 - Dados de Tráfego do Projeto Original

Tabela 5.5 - Tipos de Solo (DNER-PRO 269/94)

Tabela 5.6 - Composição da Mistura Aplicada

Tabela 5.7 - Características das Misturas Dosadas (Fonte: Consórcio Construban)

Tabela 5.8 - Ensaios realizados nos Corpos de Prova (CAP40)

Tabela 5.9 - Ensaios realizados nos Corpos de Prova (CAP40+1,5\%Polímero)

Tabela 5.10 - Resultados Deflectométricos da SP-330

Tabela 5.11 - Nível de Trincamento entre 2002 e 2006

Tabela 5.12 - Valores de Resistência à Derrapagem (VRD) e de Profundidade Média de Mancha de Areia (HS) de Janeiro de 2006 


\section{LISTA DE FIGURAS}

Figura 1.1 - Condição da Malha Administrada pelo DNIT (DNIT, 2006)

Figura 2.1 - Esquema Simplificado da Produção de Asfalto (PINTO, 1998)

Figura 2.2 - Esquema Simplificado da Produção de Asfalto (2 Estágios de Destilação). (PINTO, 1998)

Figura 2.3 - Esquema Simplificado da Produção de Asfalto (3 Estágios de Destilação) (PINTO, 1998)

Figura 2.4 - Representação da estrutura coloidal de cimento asfáltico (YEN, 1984)

Figura 2.5 - Representação esquemática da análise da composição química de um ligante asfáltico (WHITEOAK,1990)

Figura 2.6 - Reômetro de Cisalhamento Dinâmico (Leite, 1999)

Figura 2.7 - Cálculo do Módulo Complexo de Cisalhamento G* e do Ângulo de fase $\delta$ (MOTTA et al., 1996)

Figura 2.8 - Esquema do Viscosímetro Rotacional (LEITE, 1999)

Figura 2.9 - Reômetro de fluência em viga (MOTTA et al, 1996)

Figura 2.10 - Esquema do Teste da Tração Direta (LEITE, 1999)

Figura 2.11 - Conformação planar das moléculas de EVA (LEITE, 1999)

Figura 2.12 - Representação do Polímero SBS (DNER, 1998)

Figura 2.13 - Polímero do tipo RET

Figura 2.14 - Representação do Polímero RET

Figura 2.15 - Reação do Asfalteno com Polímero do Tipo RET 
Figura 2.16 - Asfalto Modificado com polímero não reativo, por ser uma modificação mecânica existe a possibilidade de segregação

Figura 2.17 - O polímero RET se mistura fisicamente com o asfalto evitando futuras separações

Figura 2.18 - Tanque de Modificação Instalado em Obra

Figura 2.19 - Detalhe do Agitador dentro do Tanque

Figura 2.20 - Teste de Hamburgo

Figura 2.21- Gráfico da Deformação Permanente (Teste de Hamburgo)

Figura 2.22 - Tanques de Modificação de Asfalto no Brasil

Figura 3.1 - Curvas Granulométricas dos Agregados Empregados

Figura 3.2 - Comparativo entre a Curva de Projeto e a faixa III do DERSA

Figura 3.3 - Sensibilidade do CAP às variações da temperatura

Figura 3.4- Suscetibilidade Térmica em termos de penetração

Figura 3.5 - Misturadora

Figura 3.6 - Mesa Compactadora tipo LCPC

Figura 3.7 - Simulador LPC

Figura 3.8 - Curvas Granulométricas dos Agregados Empregados

Figura 3.9 - Comparativo entre a Curva de Projeto, EME 0/14 e faixa B do DNER.

Figura 3.10 - Tanque Adaptado para Modificação de Asfalto

Figura 3.11 - Bacia de deflexões medida com o FWD (DYNATEST INC, 1995)

Figura 3.12 - Pêndulo britânico

Figura 3.13 - Ensaio da Mancha de Areia

Figura 4.1 - Equipamento para Modificação em Laboratório 
Figura 4.2 - Valores de Penetração para o CAP20 e modificados

Figura 4.3 - Valores de Penetração para o CAP40 e modificados

Figura 4.4 - Valores de Penetração para o CAP40 e modificados

Figura 4.5 - Valores da Ductilidade para o CAP20 e Modificados

Figura 4.6 - Valores da Ductilidade para o CAP40 e Modificados

Figura 4.7 - Resultado dos Retornos Elásticos encontrados para os ligantes modificados testados

Figura 4.8 - Gráfico da variação da viscosidade em função da temperatura (CAP20)

Figura 4.9 - Gráfico da variação da viscosidade em função da temperatura (CAP40)

Figura 4.10 - Aumento da Viscosidade em função do teor de polímero $\left(135^{\circ} \mathrm{C}\right)$

Figura 4.11 - Variação da Massa após o ensaio do ECA

Figura 4.12 - Variação percentual da Penetração antes e depois do ECA

Figura 4.13 - IST dos ligantes Estudados

Figura 4.14 - Resultado do Ensaio de Compatibilidade entre o polímero RET e o CAP20

Figura 4.15 - Resultado do Ensaio de Compatibilidade entre o polímero RET e o CAP40

Figura 4.16 - Gráfico de Densidade Aparente Máxima x Teor do Asfalto $(\mathrm{CAP} 20+1,5 \% \mathrm{RET}+0,22 \% \mathrm{CAT})$

Figura 4.17 - Gráfico de Fluência x Teor do Asfalto (CAP20+1,5\%RET $+0,22 \%$ CAT)

Figura 4.18 - Gráfico de Vazios de Ar x Teor do Asfalto(CAP20+1,5\%RET $+0,22 \%$ CAT) 
Figura 4.19 - Gráfico de Resistência à Tração x Teor do Asfalto (CAP20+1,5\%RET $+0,22 \%$ CAT)

Figura 4.20 - Gráfico de Estabilidade x Teor do Asfalto (CAP20+1,5\%RET $+0,22 \%$ CAT)

Figura 4.21 - Gráfico de Relação Betume Vazios x Teor do Asfalto (CAP20+1,5\%RET $+0,22 \%$ CAT)

Figura 4.22 - Gráfico de Densidade Aparente Máxima x Teor do Asfalto $(\mathrm{CAP} 40+1 \% \mathrm{RET}+0,22 \% \mathrm{CAT})$

Figura 4.23 - Gráfico de Fluência x Teor do Asfalto (CAP40+1\%RET+0,22\%CAT)

Figura 4.24 - Gráfico de Vazio de Ar x Teor do Asfalto $(\mathrm{CAP} 40+1 \% \mathrm{RET}+0,22 \% \mathrm{CAT})$

Figura 4.25 - Gráfico de Resistência à Tração x Teor do Asfalto $(\mathrm{CAP} 40+1 \% \mathrm{RET}+0,22 \% \mathrm{CAT})$

Figura 4.26 - Gráfico de Estabilidade x Teor do Asfalto $(\mathrm{CAP} 40+1 \% \mathrm{RET}+0,22 \% \mathrm{CAT})$

Figura 4.27 - Gráfico de Relação Betume Vazios x Teor do Asfalto (CAP40+10\%RET $+0,22 \% \mathrm{CAT})$

Figura 4.28 - Ensaio de Deformação Permanente em Simulador do tipo LPC (CAP20/CAP20+1,5\%RET+0,22\%RET)

Figura 4.29 - Ensaio de Deformação Permanente em Simulador do tipo LPC (CAP40/CAP40+1\%RET+0,22\%RET)

Figura 4.30 - Placa ensaiada após 30.000 ciclos a $60^{\circ} \mathrm{C}-\mathrm{CAP} 20$

Figura 4.31 - Placa ensaiada após 30.000 ciclos a $60^{\circ} \mathrm{C}-$ CAP $20+1,5 \%$ RET $+0,22 \%$ CAT

Figura 4.32 - Placa ensaiada após 30.000 ciclos a $60^{\circ} \mathrm{C}$ - CAP40 
Figura 4.33 - Placa ensaiada após 30.000 ciclos a $60^{\circ} \mathrm{C}-$ CAP $40+1 \%$ RET $+0,22 \%$ CAT

Figura 5.1 - Ilustração da localização da via SP-330, local onde foi executado o trecho experimental

Figura 5.2 - Estrutura do Pavimento existente do km 79+500 ao km 81+500

Figura 5.3 - Irregularidade Longitudinal (QI em cont/km) antes da Restauração

Figura 5.4 - Espessuras de Reforço Dimensionadas

Figura 5.5 - Espessuras de Reforço Calculadas pela Norma DNER-PRO 159/85

Figura 5.6 - Soluções de Restauração Adotadas

Figura 5.7 - Vista geral do processo de compactação do trecho experimental

Figura 5.8 - Trecho Experimental sendo executado

Figura 5.9 - Aplicação do Concreto Asfáltico com Asfalto Modificado por Polímero RET

Figura 5.10 - Deflexões medidas antes da Restauração

Figura 5.11 - Comparativo entre a Deflexão Medida antes da restauração e após

Figura 5.12 - Comparativo - Deflexão Medida em Maio de 2004 e Janeiro de 2006

Figura 5.13 - Comparativo das Irregularidades Longitudinais - Faixa. Interna

Figura 5.14 - Comparativo das Irregularidades Longitudinais - Faixa.Intermediária

Figura 5.15 - Comparativo das Irregularidades Longitudinais - Faixa Externa

Figura 5.16 - LVD - Fevereiro de $2002-\mathrm{km} \mathrm{79+500} \mathrm{ao} \mathrm{km} \mathrm{80+000}$

Figura 5.17 - LVD - Janeiro de 2006 - km 79+500 ao km 80+000

Figura 5.18 - LVD - Fevereiro de 2002 - km 80+000 ao km 81+000 
Figura 5.19 - LVD - Janeiro de 2006 - km 80+000 ao km 81+000

Figura 5.20 - LVD - Fevereiro de $2002-\mathrm{km} \mathrm{81+000} \mathrm{ao} \mathrm{km} \mathrm{81+500}$

Figura 5.21 - LVD - Janeiro de 2006 - km 81+000 ao km 81+500 


\section{LISTA DE ABREVIATURAS}

\begin{tabular}{|c|c|}
\hline AASHTO & American Association of State Highway and Transportation Officials \\
\hline ABNT & Associação Brasileira de Normas Técnicas \\
\hline $\mathrm{ABPv}$ & Associação Brasileira de Pavimentação \\
\hline ASTM & American Society of Testing Materials \\
\hline BBR & Reômetro de fluência em viga \\
\hline CAP & Cimento asfáltico de petróleo \\
\hline CBUQ & Concreto betuminoso usinado a quente \\
\hline CNT & Confederação Nacional dos Transportes \\
\hline Dadm & Deflexão admissível \\
\hline DDT & Prensa de Tração Direta \\
\hline DDT & Prensa de Tração Direta \\
\hline $\mathrm{DER} / \mathrm{SP}$ & Departamento de Estradas de Rodagem do Estado de São Paulo \\
\hline DERSA & Desenvolvimento Rodoviário as \\
\hline DINAPAV & Dinâmica dos Pavimentos \\
\hline DNER & Departamento Nacional de Estradas de Rodagem \\
\hline DNIT & Departamento Nacional de Infra-estrutura de Transportes \\
\hline DSR & Reômetro de cisalhamento dinâmico \\
\hline EUA & Estados Unidos da América \\
\hline EVA & Etileno-vinil-acetato \\
\hline FC-1 & Trinca classe 1 \\
\hline $\mathrm{FC}-2$ & Trinca classe 2 \\
\hline FC-3 & Trinca classe 3 \\
\hline FHWA & Federal Highway Administration \\
\hline FWD & Falling Weight Deflectometer \\
\hline
\end{tabular}




\begin{tabular}{|c|c|}
\hline GEIPOT & Empresa Brasileira de Planejamento de Transportes \\
\hline Hef & Espessura efetiva de concreto betuminoso \\
\hline HR & Espessura de Reforço Calculada \\
\hline HS & Altura de areia, em mm \\
\hline HWD & Heavy Weight Deflectometer \\
\hline IBP & Istituto Brasileiro de Petróleo \\
\hline IRI & International Roughness Index \\
\hline LPC & Laboratoire Central dês Ponts et Chaussées \\
\hline LVD & Levantamento Visual Detalhado \\
\hline NDT & Ensaios não-destrutivos \\
\hline Número $\mathrm{N}$ & Número de operações equivalentes do eixo padrão rodoviário \\
\hline QI & Quociente de irregularidade \\
\hline RBV & Relação betume vazios \\
\hline RET & Reactive Elastomeric Terpolymer \\
\hline SBR & Estireno-butadieno \\
\hline SBS & Estireno-butadieno-estireno \\
\hline SHRP & Strategic Highway Research Program \\
\hline USACE & United States Corp of Engineers \\
\hline VAM & Vazios do agregado mineral \\
\hline VRD & Valor de resistência a derrapagem \\
\hline VTR & Viscosímetro rotacional \\
\hline VV & Volume de vazios \\
\hline
\end{tabular}




\section{LISTA DE SÍMBOLOS}

\begin{tabular}{|c|c|}
\hline $\mathrm{cm}$ & Centímetros \\
\hline $\operatorname{cont} / \mathrm{km}$ & Contagem por quilômetro \\
\hline d & Distância \\
\hline$\delta$ & Ângulo de Fase \\
\hline $\mathrm{Df}_{1}$ & Deflexão medida sob a ação da carga \\
\hline$\Delta \mathrm{t}$ & Tempo de Defasagem \\
\hline $\mathrm{G}^{*}$ & Módulo Complexo de Cisalhamento \\
\hline $\mathrm{g} / \mathrm{cm}^{3}$ & Gramas por centímetro cúbico \\
\hline$\gamma_{\max }$ & Máxima Deformação \\
\hline HP & Cavalo de força \\
\hline $\mathrm{kg}$ & Quilograma \\
\hline $\mathrm{kgf} / \mathrm{cm}^{2}$ & Quilograma força por metro quadrado \\
\hline $\mathrm{km}$ & Quilômetro \\
\hline $\mathrm{km} / \mathrm{h}$ & Quilômetros por hora \\
\hline $\mathrm{kN}$ & Quilonewton \\
\hline $\mathrm{kPa}$ & Quilopascal \\
\hline $\mathrm{Lb}$ & Libras \\
\hline $\mathrm{m}$ & Metros \\
\hline $\mathrm{m} / \mathrm{km}$ & Metro por quilômetro \\
\hline $\mathrm{m}^{2}$ & Metro quadrado \\
\hline $\mathrm{nm}$ & Milímetros \\
\hline
\end{tabular}




$\begin{array}{ll}\text { Mpa } & \text { Megapascal } \\ \mathrm{N} & \text { Número equivalente de operações do eixo padrão rodoviário } \\ { }^{\circ} \mathrm{C} & \text { Graus Celsius } \\ \mathrm{P} & \text { Poise } \\ \text { RPM } & \text { Rotações por minuto } \\ \mathrm{S} & \text { Segundos } \\ \mathrm{T} & \text { Tempo } \\ \tau_{\mathrm{max}} & \text { Máxima Tensão de Cisalhamento Aplicada } \\ \text { TR } & \text { Percentual da área que apresenta trincas com largura superior a 1mm } \\ & \\ \mathrm{V} & \text { Velocidade } \\ \omega & \text { Freqüência Angular }\end{array}$




\section{INTRODUÇÃO}

O transporte rodoviário no Brasil é a principal forma de escoamento da produção e de deslocamento de passageiros. Segundo dados do Geipot no ano de 2000 (Tabela 1.1) cerca de $95 \%$ dos passageiros (1,3 bilhão de pessoas) e $60 \%$ da carga foram transportados por nossas rodovias. A malha rodoviária é a segunda maior do mundo, com mais de 1,6 milhão de quilômetros, embora menos de 10\% esteja pavimentada.

Tabela 1.1 - A matriz de transporte do Brasil (Geipot, 2000)

\begin{tabular}{|c|c|c|c|c|c|}
\hline \multicolumn{7}{|c|}{ A matriz de transporte } \\
\hline \multicolumn{7}{|c|}{ Como a carga é levada (em \% por tonelada/km) } \\
\hline Meio de transporte & 1996 & 1997 & 1998 & 1999 & 2000 \\
\hline Aéreo & 0,33 & 0,26 & 0,31 & 0,31 & 0,33 \\
\hline Aquaviário & 11,47 & 11,56 & 12,69 & 13,19 & 13,86 \\
\hline Dutoviário & 3,78 & 4,55 & 4,44 & 4,61 & 4,46 \\
\hline Ferroviário & 20,74 & 20,72 & 19,99 & 19,60 & 20,86 \\
\hline Rodoviário & 63,68 & 62,91 & 62,57 & 62,29 & 60,49 \\
\hline Total & 100,00 & 100,00 & 100,00 & 100,00 & 100,00 \\
\hline
\end{tabular}

Em 1954 o Brasil registrava 1.200 quilômetros de rodovias pavimentadas, em 1970 este número atingiu 50.590 e em 1990 chegou a 148.121. Atualmente são pouco mais de 150.000 quilômetros sendo que a pavimentação de rodovias praticamente se estagnou na última década. (Ministério dos Transportes, 2005)

Em pesquisa realizada regularmente pela Confederação Nacional dos Transportes (CNT), constatou-se que, dos $45.294 \mathrm{~km}$ de rodovias federais avaliadas em 2004, 
$66,3 \%$ encontravam-se em condições "Deficientes", $2,2 \%$ em estado "Ruim" e $0,3 \%$ em estado "Péssimo". Apenas 2,9 \% da malha receberam a qualificação "Ótima" e 28,4\% foram consideradas "Boas" (CNT, 2005). Números ainda tímidos pela importância econômica do setor. Segundo estudos da Cepal, as rodovias em más condições estão causando prejuízos ao Brasil da ordem de $3 \%$ do valor do PIB (Ministério dos Transportes, 2005).

Segundo dados obtidos no site do DNIT (DNIT, 2006) apenas 37\% da malha administrada pelo órgão encontra-se em estado "Bom" ou "Excelente" e os outros 56\% encontram-se classificados como "Regular", "Mau" ou "Péssimo", 7\% da malha não foi considerada nesta estatística.

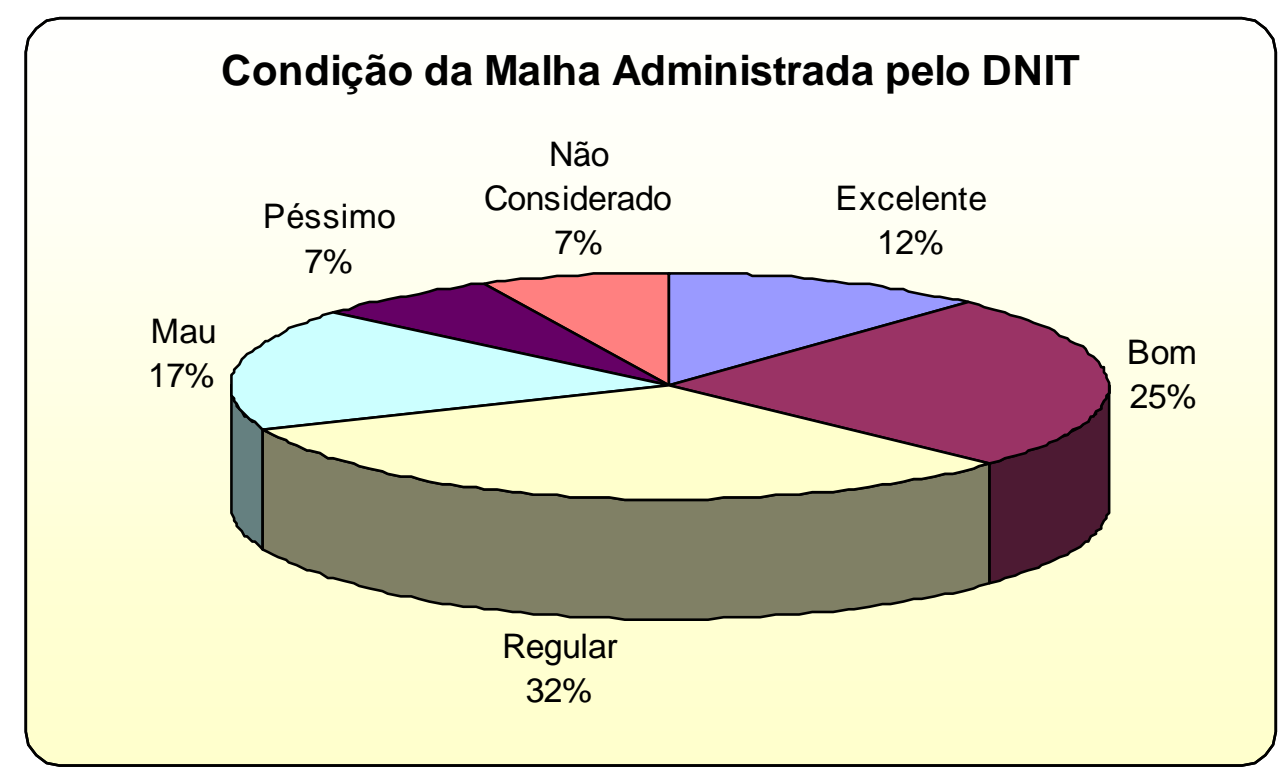

Figura 1.1 - Condição da Malha Administrada pelo DNIT (DNIT, 2006)

Informações do Geipot mostram que somente entre 1997 e 2000, nas rodovias federais pavimentadas 27.703 pessoas perderam a vida e 249.021 ficaram feridas, em 474.114 acidentes.

Sendo assim pode-se perceber a importância de uma política séria voltada à manutenção das rodovias existentes e a implantação de novos corredores rodoviários, fatores imprescindíveis para a redução do custo do transporte no país e melhoria das 
condições de segurança e conforto aos usuários. Neste contexto a utilização de novas tecnologias e a otimização dos processos existentes torna-se um fator imprescindível.

Embora muito preso à experiência de países mais desenvolvidos, de regiões de clima temperado e frio, os engenheiros rodoviários brasileiros têm realizado algumas adaptações e até observações originais sobre a avaliação e o desempenho de soluções adotadas na restauração e implantação de rodovias.

Como iniciativas de maior importância, destacam-se as recentes aplicações de novas tecnologias em rodovias sob regime de concessão, cujos resultados vem favorecendo a implementação de políticas de manutenção e recuperação dos pavimentos com maior ênfase nas restrições orçamentárias para tais atividades em nosso país.

Entre as novas tecnologias disponíveis hoje no mercado a utilização de ligantes asfálticos modificados por polímero têm ganhado um grande destaque.

Os asfaltos modificados por polímeros são obtidos a partir da incorporação do polímero ao cimento asfáltico, em unidade apropriada, podendo ou não envolver reação química. Os polímeros mais amplamente utilizados na modificação de ligantes asfálticos para fins de pavimentação no Brasil são: SBS (copolímero de estireno butadieno), SBR (borracha de butadieno estireno), EVA (copolímero de etileno acetato de vinila) e o RET (coluna de etileno com dois copolímeros acoplados).

O polímero RET, que em português quer dizer Terpolímero Elastomérico Reativo, é um polímero novo no Brasil, tendo sido projetado especificamente para a modificação de asfaltos. O desenvolvimento do produto se deu a partir de 1988, quando as companhias Chevron (petroleira) e DuPont (química) se uniram em um esforço conjunto para desenvolver um novo polímero modificador de asfalto que oferecesse as seguintes características: 
- Facilidade na incorporação no ligante asfáltico, a partir da agitação física em tanques apropriados durante curtos períodos de tempo (inferior a 5 horas);

- Possibilidade da incorporação do polímero ao ligante asfáltico ser realizada em usinas convencionais de produção de misturas asfálticas, possibilitando ajustes aos teores de polímero em função das heterogeneidades dos ligantes e reduzir possivelmente os custos do produto final;

- Obter produtos finais quimicamente modificados, com "estabilidade" dos componentes que dispensam a necessidade de agitação contínua durante o "estoque" dos produtos;

- Propriedades viscoelásticas equivalentes aos demais polímeros utilizados para pavimentação.

Estas características do polímero RET motivaram o desenvolvimento do presente trabalho, como contribuição à implementação desse processo de modificação nas obras brasileiras.

\subsection{ObJetivos}

O presente trabalho tem como objetivos avaliar as alterações das propriedades dos asfaltos pela modificação por polímeros RET (Reactive Elastomeric Terpolymer) e do comportamento de misturas asfálticas densas usinadas com estes asfaltos modificados..

Para atingir este objetivo, foi elaborado um estudo que compreende a modificação de ligantes asfálticos com diversos teores de polímero RET (1\%, 1,5\% e 2\%), com posterior dosagem de uma mistura na Faixa III do DERSA no teor considerado como mais adequado. Para verificação das propriedades mecânicas desta mistura, foram realizados ensaios de Módulo se Resiliência, Resistência à Tração por Compressão Diametral e Resistência à Deformação Permanente em simulador do tipo LPC. Além disso, são apresentados os resultados de monitoramento realizado no trecho experimental executado na SP-330 - Rodovia Anhanguera que empregou este tipo de asfalto modificado. 


\subsection{ESTRUTURA Do TrabalHo}

O presente estudo foi organizado em 6 capítulos que são descritos sucintamente a seguir:

O Capítulo 1 introduz o tema da dissertação no contexto do desenvolvimento tecnológico rodoviário, apresenta os objetivos e a organização do estudo.

O Capítulo 2 contém a revisão bibliográfica referente ao ligante asfáltico, sua química, características físicas e reológicas, bem como o seu comportamento quando modificado pelos principais modificadores utilizados no país (SBS, SBR, EVA e RET).

O Capítulo 3 consiste na apresentação dos materiais utilizados para 0 desenvolvimento do trabalho, bem como as metodologias seguidas na realização dos ensaios de laboratório e campo. Os ensaios de Deformação Permanente em trilha de roda com equipamento do tipo LPC, por se tratar de ensaio não rotineiro em nosso país, terá sua descrição mais detalhada.

O Capítulo 4 refere-se à apresentação e análise dos resultados encontrados em laboratório.

O Capítulo 5 apresenta um Estudo de Caso referente ao segmento experimental executado em Maio de 2002 na SP-330 (Rodovia Anhangüera). Durante os anos de 2002, 2003, 2004 e 2005 foram realizados ensaios de monitoramento das condições funcionais e estruturais dos pavimentos. Neste capítulo são abordados também os detalhes de aplicação.

No Capítulo 6 são apresentadas as conclusões obtidas através da análise dos resultados e as sugestões para as próximas pesquisas a serem realizadas sobre este assunto. 


\section{REVISÃO BIBLIOGRÁFICA}

\subsection{INTRODUÇÃo}

O asfalto é, sem dúvida, um dos mais antigos materiais utilizados pelo homem. Escavações arqueológicas revelam o seu emprego em épocas anteriores à nossa Era. Assim, na Mesopotâmia, o asfalto era usado como aglutinante em trabalhos de alvenaria e construção de estradas. Os reservatórios de água e as salas de banhos eram impermeabilizados com asfalto. Citações bíblicas revelam o seu emprego como impermeabilizante na Arca de Noé. Os egípcios utilizaram o asfalto em trabalho de mumificação. A história mostra que o asfalto tende a se perpetuar ao longo dos séculos (IBP, 1999).

A partir de 1909, iniciou-se o emprego de asfalto derivado de petróleo, o qual, pelas suas características de economia e pureza, em relação aos asfaltos naturais, constitui atualmente a principal fonte de suprimento (IBP, 1999).

\subsection{Asfalto}

\subsubsection{Aspectos Gerais}

Os asfaltos são materiais aglutinantes de consistência variável, cor pardo-escura ou negra e nos quais o constituinte predominante é o betume, podendo ocorrer na natureza em jazidas ou ser obtido pela destilação do petróleo. 
Segundo a NBR 7208 (1982) o betume é uma mistura de hidro-carbonetos de consistência sólida, líquida ou gasosa, de origem natural ou pirogênica, completamente solúvel em bissulfeto de carbono $\left(\mathrm{CS}_{2}\right)$, freqüentemente acompanhado de seus derivados não metálicos.

Os asfaltos naturais podem ocorrer em depressões da crosta terrestre, constituindo os lagos de asfaltos (Trinidad, Bermudas), ou aparecerem impregnando os poros de algumas rochas, formando as denominadas rochas asfálticas (gilsonita e asfaltita). Encontram-se também misturados com impurezas minerais (areias e argilas), em quantidades variáveis, sendo geralmente submetidos a processos de purificação para serem aplicados em pavimentação (IBP, 1999).

No início do século 20, a descoberta do asfalto refinado do óleo cru do petróleo e a popularidade do automóvel criaram uma indústria em expansão. $\mathrm{O}$ asfalto parecia ser uma fonte barata e inesgotável que seria usada em estradas modernas de rolamento suave e em numerosas outras aplicações (Instituto do Asfalto, 1989).

A produção do asfalto constitui-se como um dos produtos finais da destilação do petróleo cru, no qual as frações mais leves (gasolina, querosene, diesel) são separadas do asfalto por vaporização, fracionamento e condensação (IBP, 1999).

Segundo GUARÇONI (DNER, 1998), no Brasil a maioria das refinarias operam com os mais variados tipos de crus disponíveis, sendo que para isso deve-se empregar distintos processos nas unidades refinadoras:

- Se o rendimento em asfalto for alto (cru de base naftênica), basta o estágio de destilação a vácuo no processo de refinação;

- Se o rendimento em asfalto for médio (cru de base intermediária), o processo é o de destilação em dois estágios: pressão atmosférica e vácuo;

- Se o rendimento em asfalto for baixo (petróleos leves), além da destilação em dois estágios, inclui-se o processo de desasfaltação a propano. 
Nos dois últimos processamentos, obtém-se asfaltos muito duros, necessitando de adição de outras frações do próprio refino para transformá-lo num produto que atenda às especificações brasileiras no tocante às características físicas, o que não exclui uma variação na sua constituição química, devido ao sensível desequilíbrio da estabilidade coloidal do asfalto (DNER, 1998).

Segundo o IBP (1999), dos processos apresentados o mais utilizado é o da destilação em duas etapas, pois produz o asfalto normalmente sem a necessidade de instalações especiais e permite o uso de um maior número de tipos de petróleo, consistindo, basicamente, de uma separação física dos vários constituintes do petróleo pela diferença entre seus pontos de ebulição e de condensação.

São apresentados a seguir os esquemas simplificados da produção de asfalto pelos três métodos citados acima:

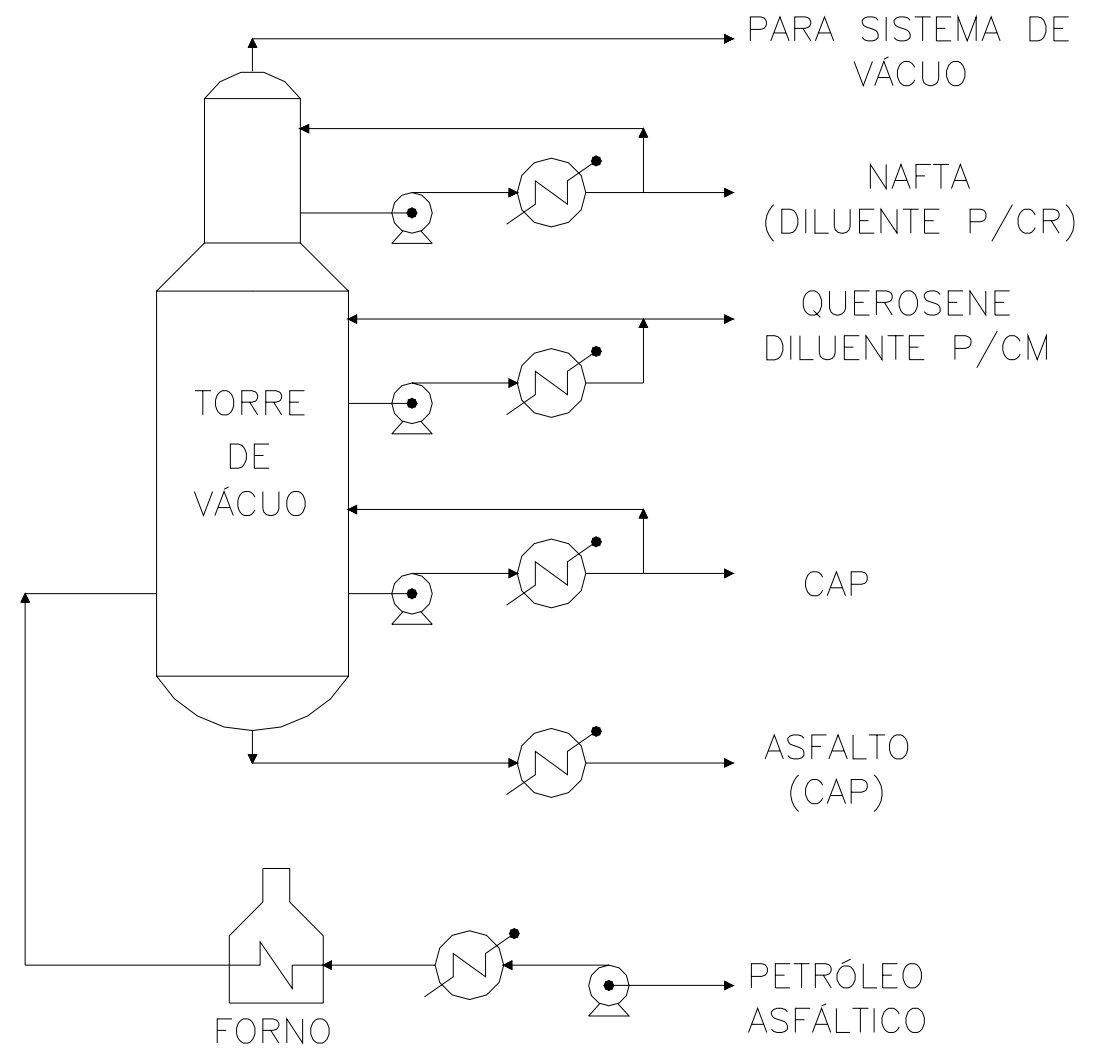

Figura 2.1 - Esquema Simplificado da Produção de Asfalto (PINTO, 1998) 


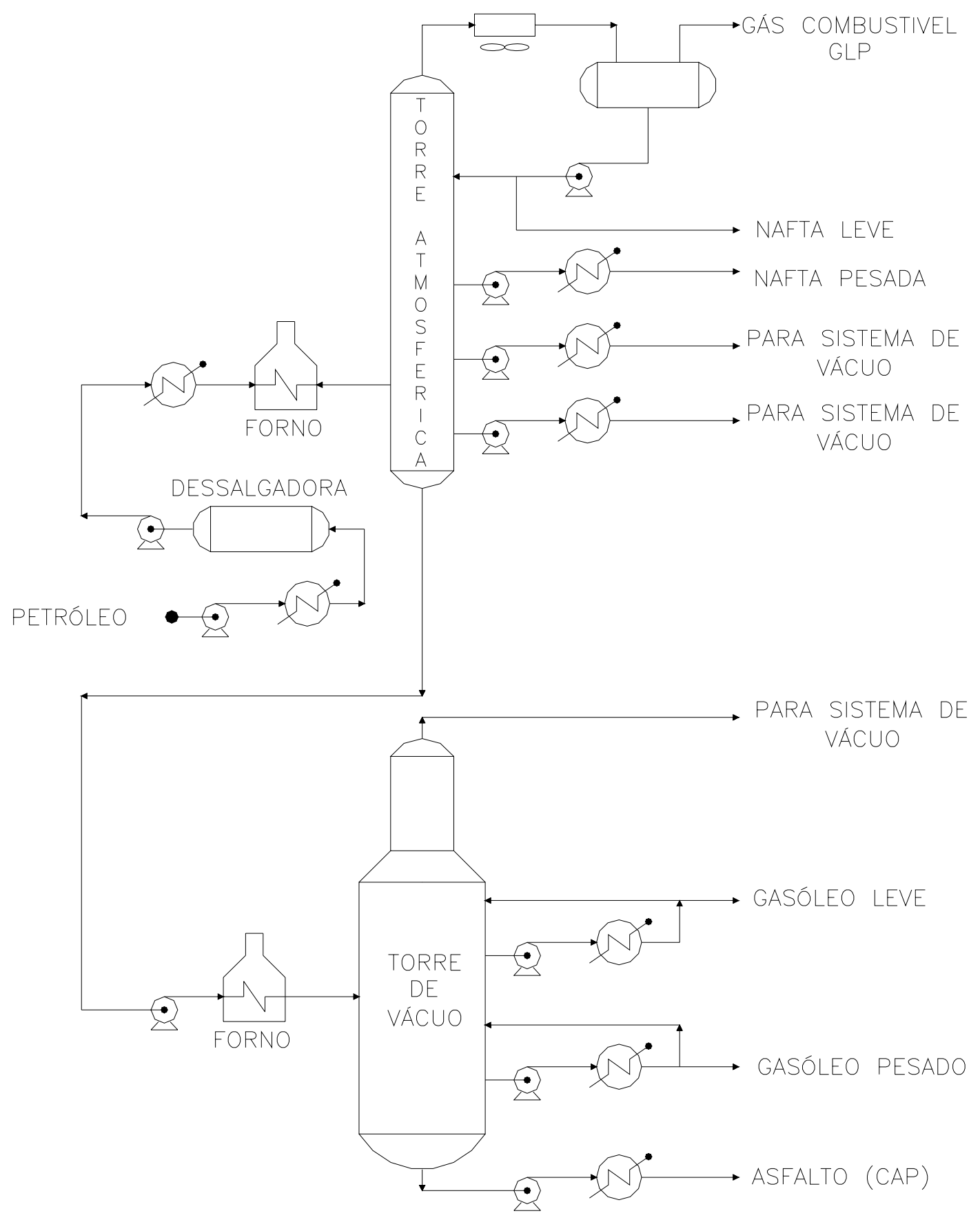

Figura 2.2 - Esquema Simplificado da Produção de Asfalto (2 Estágios de Destilação) (PINTO, 1998) 


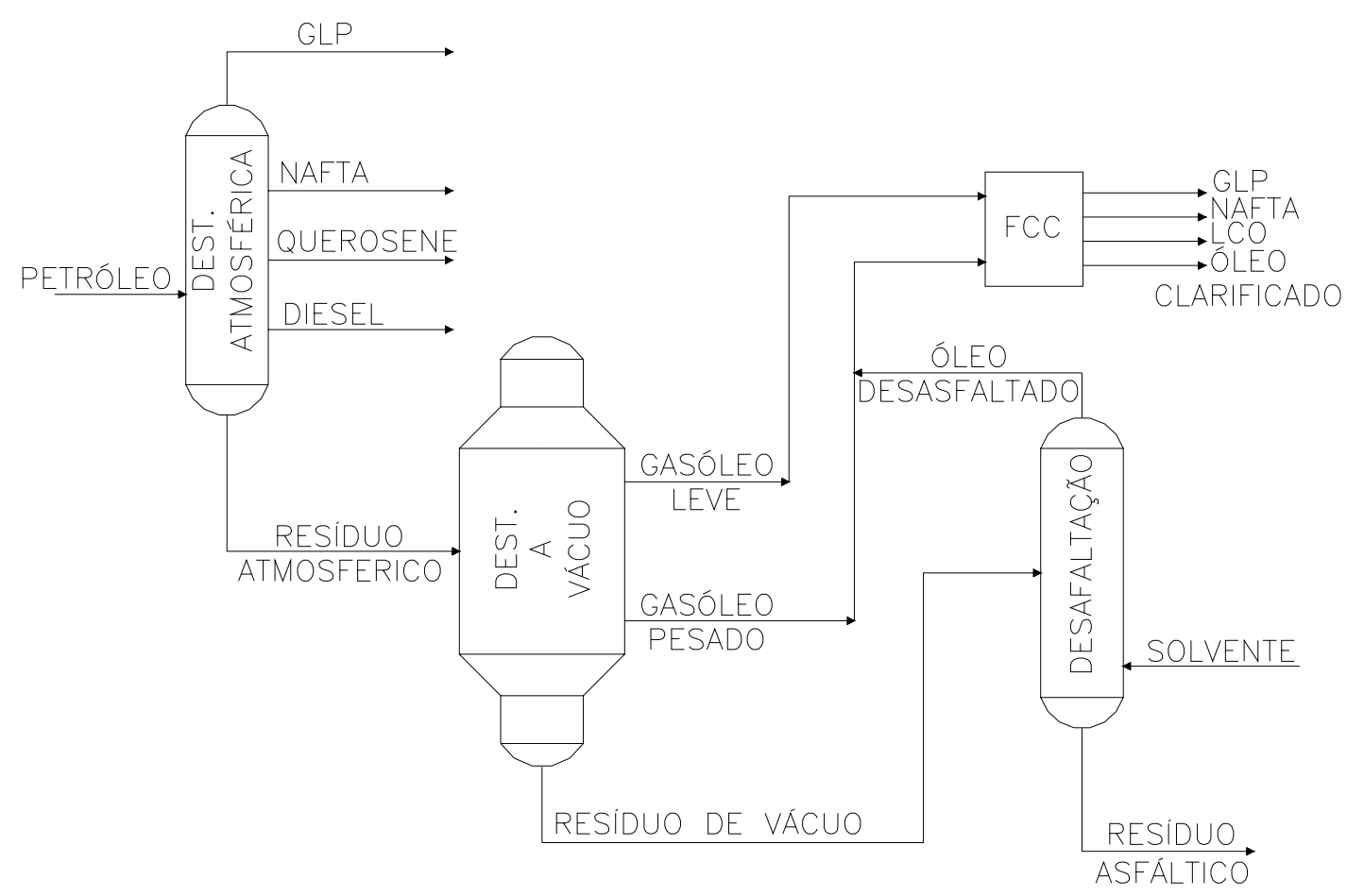

Figura 2.3 - Esquema Simplificado da Produção de Asfalto (3 Estágios de Destilação) (PINTO, 1998)

Segundo LEITE (1999) os tipos de asfalto existentes no mercado brasileiros são denominados:
a) Cimentos Asfálticos de Petróleo (CAP);
b) Asfaltos Diluídos;
c) Asfaltos Emulsionados;
d) Asfaltos Oxidados ou Soprados;
f) Agentes Rejuvenecedores.
g) Asfaltos Modificados.

\subsubsection{Cimentos Asfálticos de Petróleo (CAP)}

O cimento asfáltico é obtido especialmente para apresentar características adequadas para o uso na construção de pavimentos. Ele pode ser obtido por um dos três processos de destilação apresentados anteriormente e, sendo assim, receberá o nome 
de Cimento Asfáltico de Petróleo (CAP), ou ser obtido em Jazidas Naturais recebendo o nome de Cimento Asfáltico Natural (CAN). Estes materiais são semisólidos à temperatura ambiente, e necessitam de aquecimento para terem consistência apropriada ao envolvimento de agregados, possuem características de flexibilidade, durabilidade, aglutinação, impermeabilização e elevada resistência à maioria dos ácidos, sais e álcalis(SOUZA, 1995).

Os cimentos asfálticos de petróleo brasileiros são classificados pelo seu "grau de dureza" retratado no seu ensaio de penetração a $25^{\circ} \mathrm{C}$. O Instituto Brasileiro de Petróleo e o Departamento Nacional de Infraestrutura Terrestre (DNIT) especificam 4 tipos de CAP pela sua penetração: CAP 30-45, CAP 50-70, CAP 85-100 e CAP 150-200. Observa-se que a época da realização dos ensaios laboratoriais da presente pesquisa a classificação brasileira era realizada por viscosidade, sendo os CAP 30-45 e CAP 50-70 equivalentes aos CAP 20 e CAP 40 da antiga especificação.

\subsubsection{Asfaltos Modificados}

Para ampliar sua resistência, os cimentos asfálticos de petróleo podem ser modificados através de adições de asfaltos naturais como gilsonita (EUA), asfaltita (Argentina) e Asfalto de Trinidad ou ainda por adição de fíleres (cal, cimento, sílica etc), fibras (fibra de vidro, asbestos, fibras de celulose e fibras poliméricas) ou por enxofre elementar. A modificação mais empregada atualmente é através do uso de polímeros (SBR, SBS, EVA, RET, etc) e por borracha moída de pneu (LEITE, 1999).

O DNIT tem uma especificação de asfalto modificado por SBS feito em 1998. O IBP, pela sua Comissão de Asfalto, vem propondo especificações de asfalto e emulsão modificados por polímero, que se encontram em fase de aprovação.

\subsubsection{Química do Asfalto}


Quimicamente o asfalto é definido como um sistema coloidal constituído por micelas de asfaltenos dispersadas em um meio intermicelar oleoso, formado pela mistura de óleos aromáticos e saturados, chamado maltenos (BRULÉ, 1974).

Segundo Goodrich (1986, apud LEITE, 1999) os cimentos asfálticos de petróleo CAP - são constituídos de 90 a $95 \%$ de hidrocarbonetos e 5 a $10 \%$ de heteroátomos (oxigênio, enxofre, nitrogênio e metais - vanádio, níquel e ferro) através de ligações covalentes. A composição química é bastante complexa, sendo dependente do cru e do processo de refino, sendo que o número de átomos de carbono por molécula varia de 20 a 120. O CAP pode ser considerado uma dispersão coloidal de asfaltenos em saturados e aromáticos, circundados por resinas que agem como agentes peptizantes (YEN, 1984). A Figura 2.4 mostra um esquema dos componentes dos asfaltos.

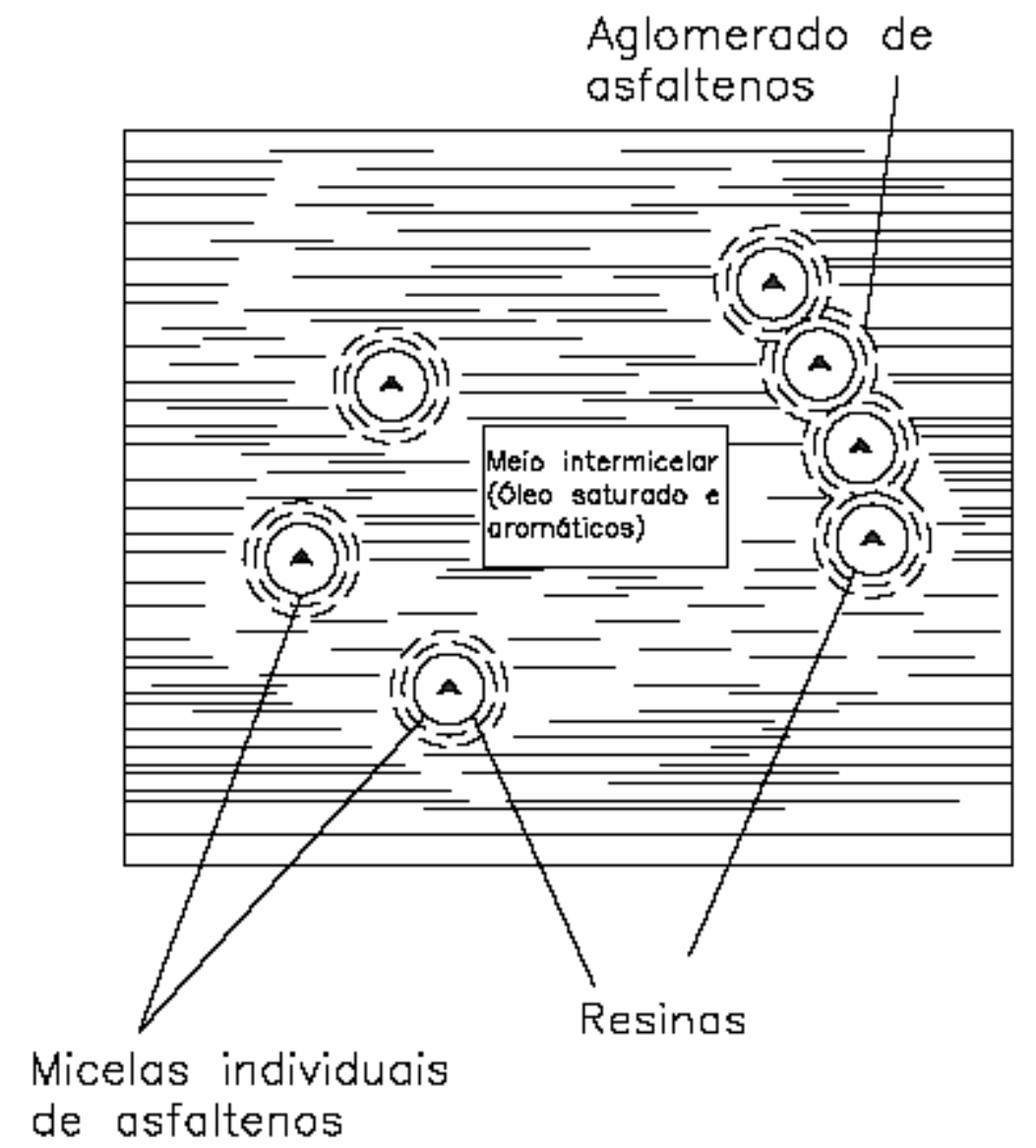

Figura 2.4 - Representação da estrutura coloidal de cimento asfáltico (YEN, 1984) 
Devido à dificuldade de se obter uma separação individual dos componentes do asfalto, vários pesquisadores desenvolveram metodologias de fracionamento químico baseadas no princípio da solubilidade, reatividade química e adsorção com a finalidade de separar conjuntos de substâncias semelhantes entre si (SOUZA et al., 1995).

Os métodos de separação do asfalto em frações têm um ponto comum: a separação da parte sólida do asfalto (os asfaltenos) pela adição de um solvente que dissolva os maltenos e não dissolva os asfaltenos. Isto é, a utilização de uma propriedade fundamental dos sistemas coloidais, que é a destruição de sua estabilidade pela eliminação da camada de proteção das micelas, que faz com que elas se associem e precipitem pela ação da gravidade. Como a estabilidade de uma micela é dada por uma camada de agente peptizante ou por camadas de solvatação, basta eliminar a proteção, que a micela sedimenta. Tal procedimento é realizado através da adição de um solvente que seja afim ao meio de dispersão e à camada de proteção, e que não tenha nenhuma afinidade pela micela (RAMOS, 1995).

Como as micelas são constituídas fundamentalmente por aromáticos, devido a sua alta relação $\mathrm{C} / \mathrm{H}$, sua separação se dá pela adição de um alcano leve. Uma vez separada a fase micelar (asfaltenos), a fase intermicelar (maltenos) fica solúvel no solvente usado, e pode então ser dividida em sub-grupos. Os sub-grupos são separados por diferentes métodos (DNER, 1998), a saber:

\section{a) Método de Schweyer e Traxler}

É o mais simples dos métodos. Baseia-se no fracionamento por solvente, com a utilização de duas etapas: na primeira, o malteno é separado do asfalto por solubilização em n-butanol, e na segunda, após a eliminação do butanol, o malteno é fracionado por acetona que após dissolver todo o óleo maltênico é resfriada, forçando a precipitação dos saturados separando-os da fração solúvel, constituído pelos cíclicos (aromáticos e resinas). Este método separa o asfalto em três frações: asfaltenos, cíclicos (resinas e aromáticos) e saturados. 
b) Método de Rostler e Sternberg

É considerado um método mais completo que o anterior, porém é também mais complexo. É padronizado pela ASTM sob o número D-2.006 e baseia-se na separação dos asfaltenos a partir da sua insolubilização em n-pentano e posterior separação das frações maltênicas por precipitação química, utilizando $\mathrm{H}_{2} \mathrm{SO}_{4}$ de densidades crescentes. Este método separa o asfalto em cinco frações: Asfaltenos, Bases Nitrogenadas, Acidafinas I, Acidafinas II e Saturados.

\section{c) Técnica da Cromatografia}

A cromatografia significa escrita de cores e foi descoberta em 1903 pelo botânico russo Tswett que, ao passar extrato de folha dissolvido em éter através de uma coluna de $\mathrm{CaCO}_{3}$ finamente dividido, observou que após a passagem do solvente haviam se formado duas zonas distintas dentro da coluna, uma verde e uma amarela, indicando que havia ocorrido separação de componentes (DNER, 1998).

Segundo AMARAL (2000), esta técnica pode ser definida como o procedimento físico-químico que permite separar os componentes de uma mistura através de suas interações com duas fases distintas, sendo uma a fase estacionária ou adsorvente e a outra a fase móvel ou solvente. Esta técnica levou ao surgimento do método da sílica-gel, também conhecido como método Rostler modificado, que baseia-se na separação dos asfaltenos pela solubilização dos maltenos em n-pentano, seguido da separação das frações maltênicas através de coluna cromatográfica, utilizando sílicagel e argila Attapulgus como fase estacionária adsorvente e, como fase móvel, solventes de polaridade crescente. Este método separa o asfalto em quatro frações: asfaltenos, resinas ou compostos polares, compostos aromáticos e saturados. A Figura 2.5 apresenta esquematicamente a análise de composição química de um ligante através desta técnica. 


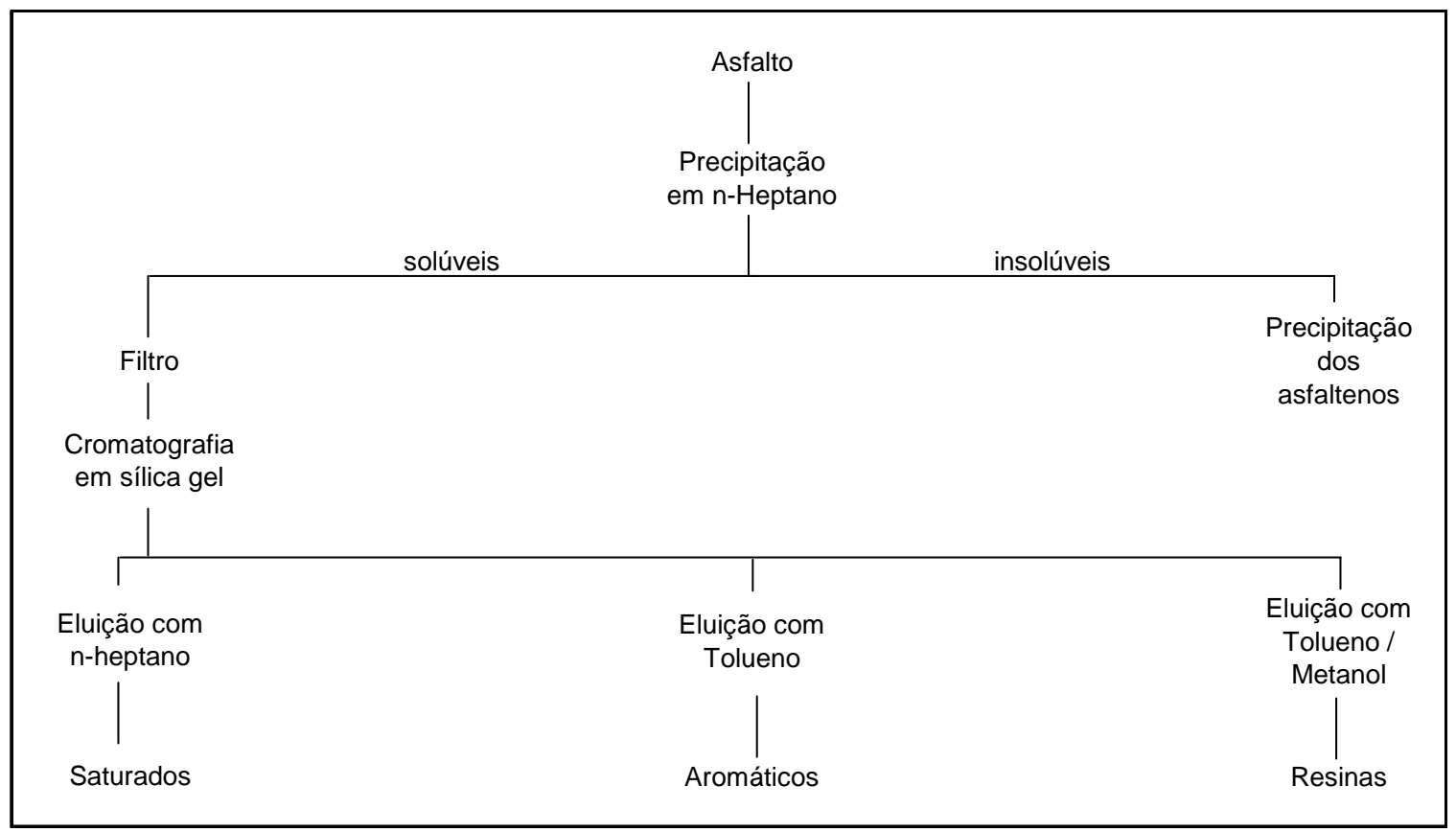

Figura 2.5 - Representação esquemática da análise da composição química de um ligante asfáltico (WHITEOAK, 1990)

d) Método de Colbert

É o método mais utilizado atualmente. Baseia-se na separação dos asfaltenos pela solubilização dos maltenos em n-heptano, seguido pela separação dos maltenos em frações de polaridades crescentes, usando como adsorvente sólido a alumina finamente dividida. Este método separa o asfalto em quatro frações: Asfaltenos, Aromáticos Polares, Aromáticos Naftênicos e Saturados.

Além destas metodologias apresentadas, existem outras mais sofisticadas tais como o SARA e a Ionização de Chama (Iatroscan), que por sua natureza utilizam equipamentos e tecnologias muito especializadas.

WHITEOAK (apud LEITE, 1999) cita que os componentes do CAP têm as seguintes propriedades:

- Saturados - têm influência negativa na suscetibilidade térmica. Em maior concentração amolecem o produto; 
- Aromáticos - agem como plastificantes, contribuindo para a melhoria de suas propriedades físicas;

- Resinas - têm influência negativa na suscetibilidade térmica, mas contribuem na melhoria da ductilidade e dispersão dos asfaltenos;

- Asfaltenos - contribuem para a melhoria da suscetibilidade térmica e aumento da viscosidade.

Embora a composição química e a estrutura coloidal sejam somente auxiliares na explicação de alguns fenômenos do comportamento do CAP como ligante rodoviário, os parâmetros reológicos de CAP obtidos através de viscosímetros e reômetros de cisalhamento dinâmico apresentam correlação com ensaios de desempenho de misturas betuminosas (LEITE, 1999).

\subsubsection{Reologia dos Asfaltos e Ensaios Reológicos}

Reologia é a ciência que estuda a deformação e fluxo dos materiais, seja nas formas de líquido, liquefeito ou sólido, em termos da elasticidade e da viscosidade do material. $\mathrm{O}$ asfalto é um material viso-elástico e pode exibir tanto um comportamento elástico como viscoso, ou uma combinação destes dois comportamentos, dependendo da temperatura e do tempo no qual o asfalto é observado (LU et al., 1999)

O estudo do comportamento reológico dos materiais betuminosos tem por objetivo principal encontrar a relação entre deformação, tensão, tempo de aplicação da carga e temperatura. A investigação dessas propriedades concorrem para compreensão do desempenho do CAP, quando submetido a tensões provenientes do tráfego e a tensões térmicas devido a variações da temperatura ambiente (PINTO, 1991).

Em temperaturas suficientemente baixas e/ou em altas taxas de carregamento (freqüência), o asfalto reage essencialmente como um sólido elástico. Quando a temperatura aumenta e/ou quando a taxa de carregamento reduz, a propriedade viscosidade do asfalto se torna mais evidente. Em temperaturas suficientemente altas e/ou em longo tempo de aplicação de cargas, o asfalto é essencialmente um líquido 
Newtoniano e pode ser descrito por um valor de viscosidade independente da taxa de aplicação de carga (LU et al., 1999).

As propriedades reológicas dos asfaltos podem influenciar significativamente no desempenho das misturas asfálticas durante a misturação, a compactação e em serviço. Por estas razões, vários tipos de testes reológicos são incluídos nas especificações dos asfaltos. As propriedades reológicas dos asfaltos são determinadas pelas interações moleculares (forças moleculares), que por sua vez dependem da composição química (LU et al., 1999).

Em princípio, as propriedades reológicas desejadas para o asfalto podem ser conseguidas mudando a composição química do asfalto usando um aditivo ou uma modificação através de reação química. A adição de polímero é uma alternativa versátil de modificar a reologia dos asfaltos. Muitos tipos de polímeros são aproveitáveis, entretanto, não há um polímero universal e uma seleção deveria ser feita de acordo com as necessidades (LU et al., 1999).

As propriedades reológicas dos cimentos asfálticos variam enormemente com a variação da temperatura, embora a forma dessa variação não guarde relação de simetria, já que ela varia de forma "personalizada" em cada CAP, por ser função de dependência direta da sua suscetibilidade térmica. Esta, por sua vez, depende diretamente da constituição química e da forma como as micelas e o meio intermicelar se arranjam para atingir o equilíbrio coloidal estável (DNER, 1998).

Como fator altamente complicador, aparece ainda o envelhecimento do CAP ao longo de sua vida útil. É sabido que o envelhecimento se dá pela oxidação de moléculas polarizáveis dos maltenos, que se tornam polares, e passam a fazer parte da fração asfalteno. Com isso, ao longo da vida do CAP no pavimento, ele vai gradativamente aumentando a quantidade de asfaltenos e na mesma proporção, diminuindo a quantidade de maltenos. Isto leva o CAP a um endurecimento gradativo, já que o equilíbrio coloidal está permanentemente se deslocando no sentido do aprofundamento das propriedades GEL, que aparece quando as cadeias 
estão suficientemente associadas para formar uma rede. Em conseqüência, o CAP vai perdendo as propriedades SOL (solução) e com a suscetibilidade térmica cada vez menor. Isto significa que um CAP pode apresentar uma suscetibilidade térmica dentro da faixa desejada, e logo após a usinagem (quando ocorre o maior grau de envelhecimento do CAP), ir para a pista com esta suscetibilidade completamente fora da faixa desejada. Por esta razão, torna-se necessário um profundo conhecimento da suscetibilidade térmica do CAP, e principalmente, a forma como ela se altera durante o processo de usinagem e ao longo da sua vida útil (DNER, 1998).

As especificações Superpave para ligantes asfálticos se baseiam em ensaios reológicos e têm demonstrado sua aplicabilidade na pesquisa de parâmetros que possam correlacionar as características do ligante ao desempenho das misturas asfálticas em serviço. São utilizados para esse fim os seguintes equipamentos:

- viscosímetro rotacional - VTR (ASTM D 4402);

- reômetro de cisalhamento dinâmico - DSR (ASTM P246);

- reômetro de fluência em viga-BBR (ASTM P 245);

- prensa de tração direta - DDT (ASTM P 252).

Na presente pesquisa, dentre os ensaios reológicos da especificação Superpave, serão apresentados apenas resultados de viscosidade determinados com o viscosímetro rotacional, único aparelho disponível dentre os recomendados pela especificação. Recomenda-se a complementação do estudo com a realização dos outros ensaios citados, os quais serão descritos adiante.

O reômetro de cisalhamento dinâmico (dynamical shear rheometer - DSR) é usado para caracterizar as propriedades viscoelásticas do ligante. Este mede o módulo complexo de cisalhamento $\left(\mathrm{G}^{*}\right)$ e o ângulo de fase $(\delta)$, submetendo uma pequena quantidade de ligante a tensões de cisalhamento oscilatórias, entre duas placas paralelas. O módulo $\mathrm{G}^{*}$ pode ser relacionado com a resistência do material em diferentes velocidades de cisalhamento e o ângulo $\delta$ fornece informações sobre a razão entre a resposta elástica e viscosa durante o processo de cisalhamento 
(MOTTA et al., 1996). A Figura 2.6 apresenta um esquema de um reômetro que consta das especificações SHRP.
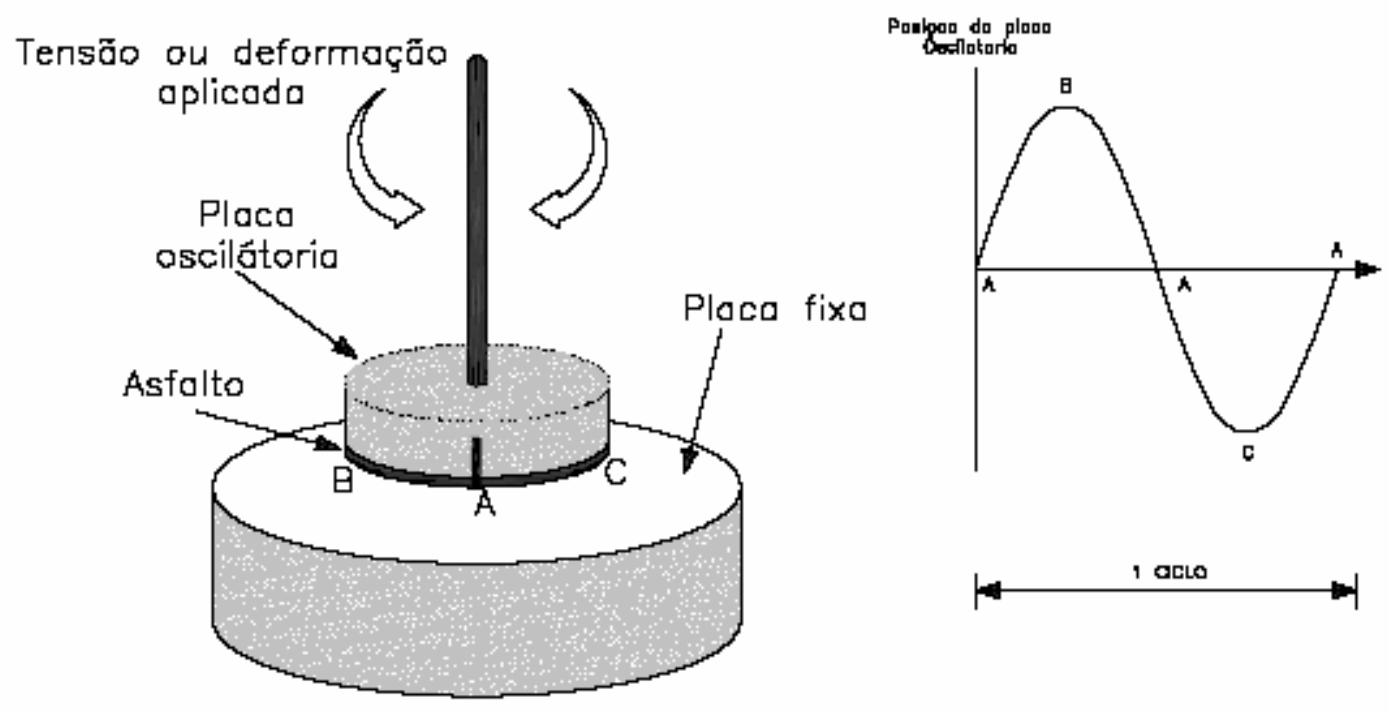

Figura 2.6 - Reômetro de Cisalhamento Dinâmico (Leite, 1999)

O módulo complexo pode ser definido como:

$$
G^{*}=\frac{\tau_{\text {máx }}}{\gamma_{\text {máx }}} \text { e } \delta=\omega \cdot(\Delta t)
$$

onde:

$\mathrm{G}^{*}=$ módulo complexo de cisalhamento;

$\tau_{\text {máx }}=$ máxima tensão de cisalhamento aplicada;

$\gamma_{\text {máx }}=$ máxima deformação devido a tensão de cisalhamento aplicada;

$\omega=$ freqüência angular;

$\Delta t \quad=$ tempo de defasagem.

A Figura 2.7 apresenta de forma esquemática os valores de $\mathrm{G}^{*}$ e $\delta$ medidos pelo DSR, como resposta a uma deformação cisalhante de uma amostra. Nesta ilustração, a resposta à deformação cisalhante de uma amostra de ligante está "defasada" em relação à tensão aplicada por um certo intervalo de tempo $\Delta t$. 


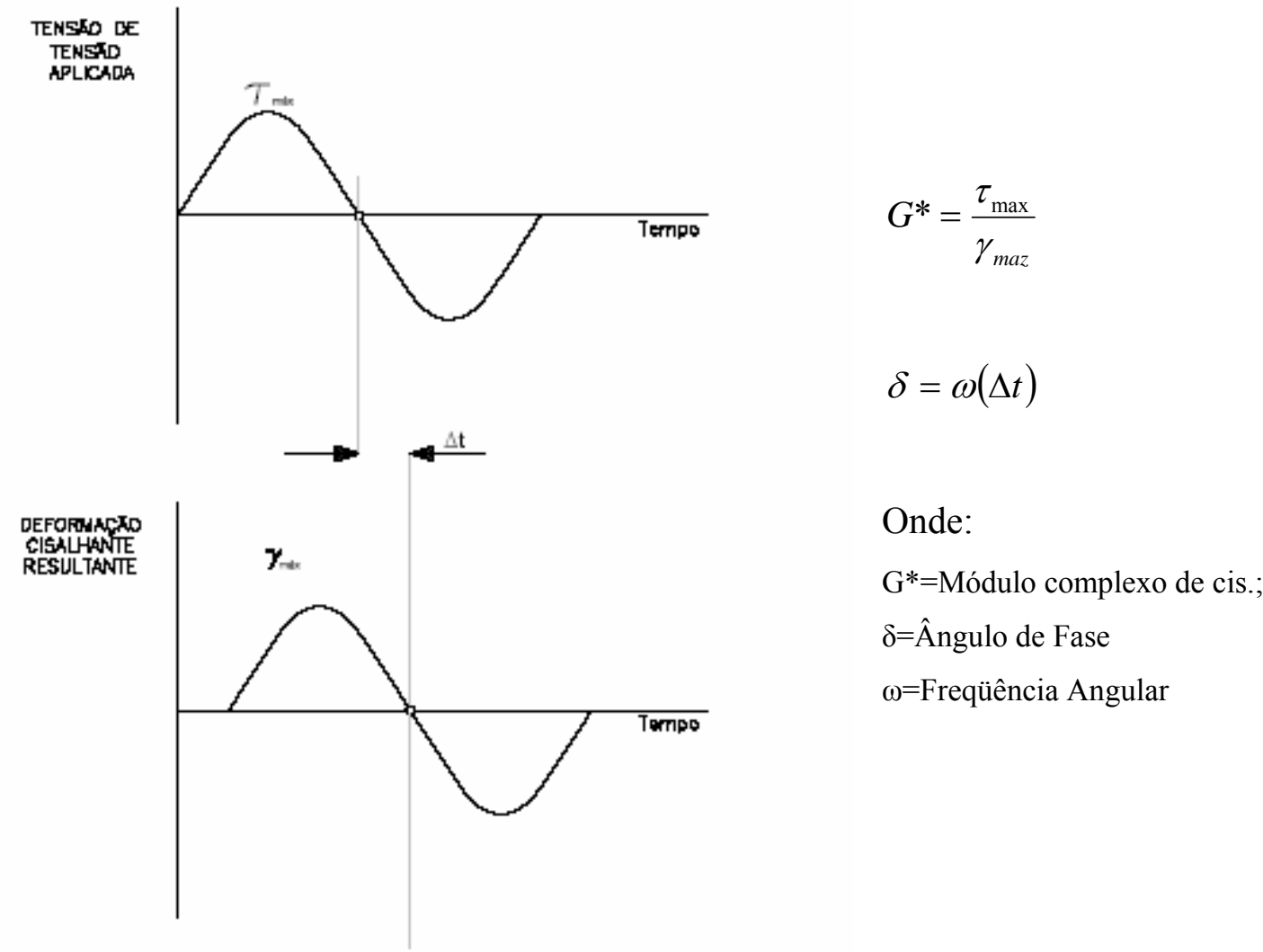

Figura 2.7 - Cálculo do Módulo Complexo de Cisalhamento $G^{*}$ e do Ângulo de fase $\delta$ (MOTTA et al., 1996)

Este intervalo de tempo representa o atraso na deformação obtida. A fase em atraso é expressa em medida angular como o tempo de atraso $(\Delta t)$ multiplicado pela freqüência angular $(\omega)$ para atingir o ângulo de fase $(\delta)$. Para materiais completamente elásticos, não existe atraso entre a tensão cisalhante aplicada e a deformação cisalhante obtida, sendo $\delta$ igual a $0^{\circ}$. Para materiais totalmente viscosos, a deformação obtida está completamente defasada e $\delta$ vale $90^{\circ}$. Materiais viscoelásticos, tais como ligantes asfálticos, possuem ângulo de fase variando entre $0^{\circ}$ e $90^{\circ}$, dependendo da temperatura. A altas temperaturas $\delta$ tende a $90^{\circ}$ e a baixas temperaturas $\delta$ tende a $0^{\circ}$. A especificação de ligante usa o parâmetro $\mathrm{G}^{*} / \operatorname{sen} \delta$ para temperaturas altas $\left(>46^{\circ} \mathrm{C}\right), \mathrm{G}^{*} \operatorname{sen}(\delta)$ para temperaturas intermediárias (entre $7^{\circ} \mathrm{C}$ e $34^{\circ} \mathrm{C}$ ) como forma de controlar a rigidez do asfalto (MOTTA et al., 1996). 
Controlando a rigidez a altas temperaturas, a especificação de ligante assegura que o asfalto forneça resistência ao cisalhamento global da mistura em termos de elasticidade a altas temperaturas. Da mesma forma, a especificação assegura que o ligante não contribua para o trincamento por fadiga controlando sua rigidez a temperaturas intermediárias (LEITE, 1999).

O viscosímetro rotacional (Rotational Viscometer - RTV) caracteriza a rigidez do asfalto a $135^{\circ} \mathrm{C}$, na qual age quase que inteiramente como um fluido viscoso. É um viscosímetro rotacional de cilindros coaxiais, que mede a viscosidade através do torque necessário para rodar um spindle imerso na amostra de asfalto quente (Figura 2.8), à velocidade constante. A especificação de ligante para o CAP 50-70, por exemplo, requer que este tenha uma viscosidade inferior a 3,5 Pa.s (3.500 cP) a $135^{\circ} \mathrm{C}$. Isto assegura que o ligante pode ser bombeado e facilmente usinado (LEITE, 1999).

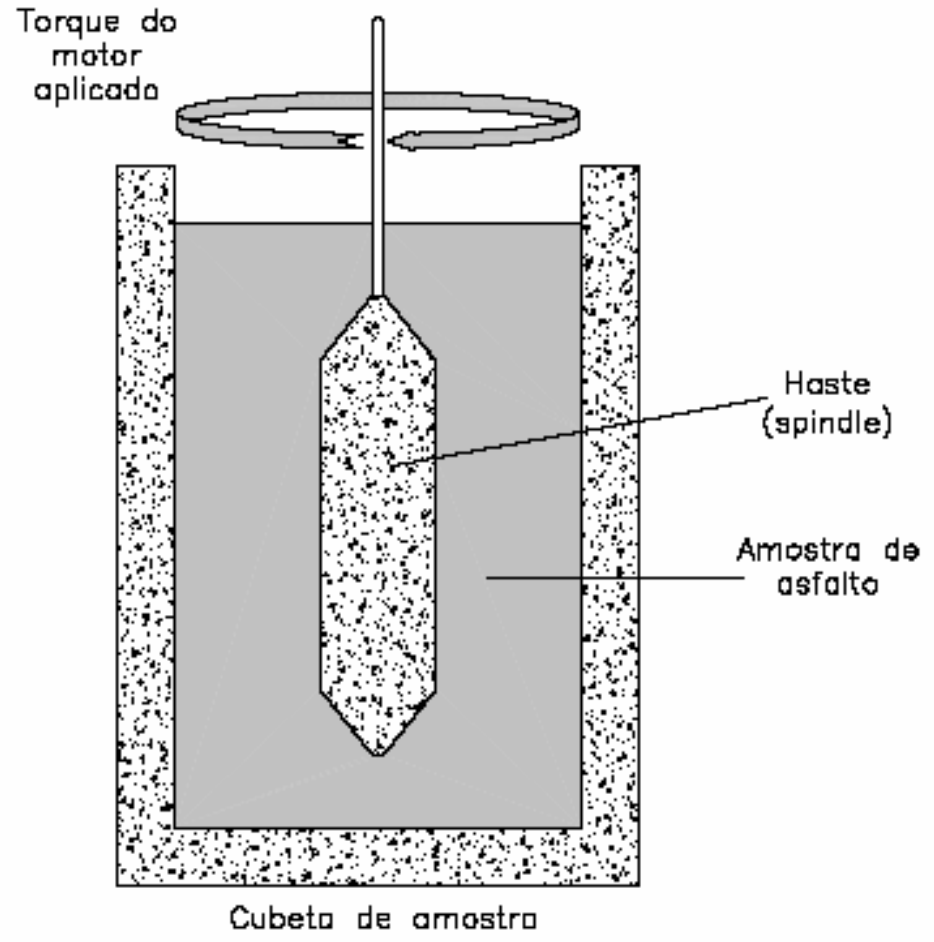

Figura 2.8 - Esquema do Viscosímetro Rotacional (LEITE, 1999) 
O reômetro de fluência de viga (Bending Beam Rheometer - BBR) é usado na caracterização da rigidez do ligante a baixa temperatura. Este mede a rigidez estática (S) e o logarítmo do módulo de relação $(\mathrm{m})$. Estas propriedades são determinadas a partir da resposta ao carregamento estático (creep) sobre uma vigota de ligante a baixas temperaturas (Figura 2.9). Conhecendo-se a carga aplicada sobre a vigota e medindo-se a deflexão ao longo do teste, a rigidez estática pode ser determinada, usando-se os fundamentos da mecânica. A especificação de ligante estabelece limites para $\mathbf{S}$ e $\mathbf{m}$ em função do clima onde o ligante será usado. Ligantes que possuam baixa rigidez estática não trincarão em clima frio. De igual forma, ligantes que possuam altos valores de $\mathbf{m}$, são mais eficientes na dissipação das tensões formadas durante a contração do ligante, quando a temperatura do pavimento cai abruptamente, minimizando a formação de trincas e fissuras (MOTTA et al., 1996).
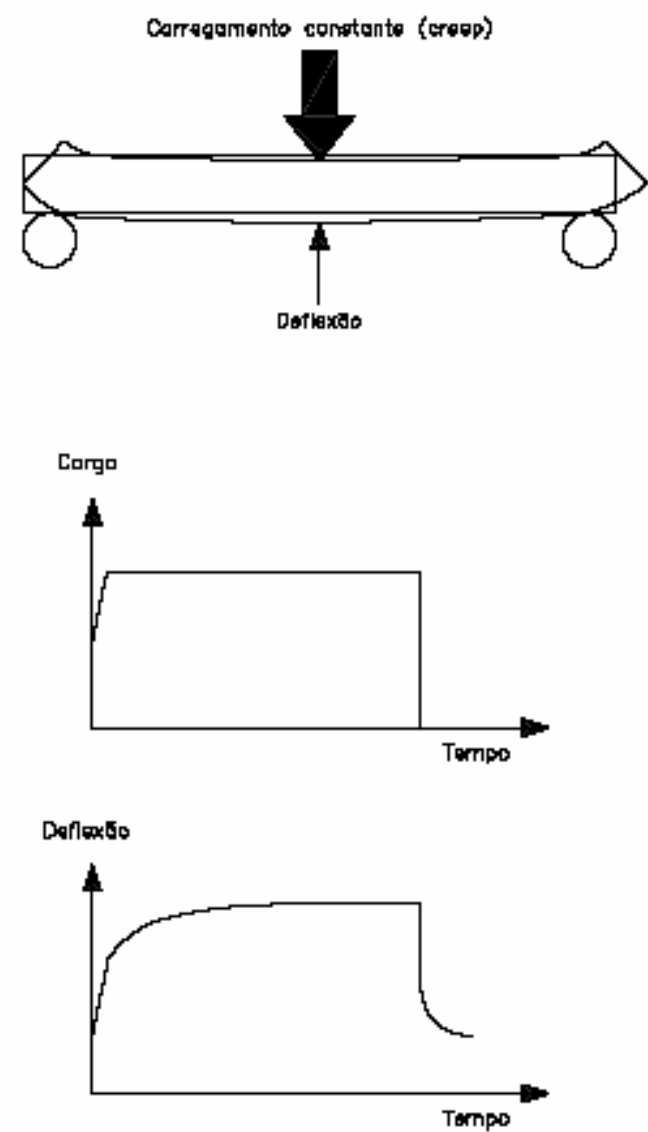

Figura 2.9 - Reômetro de fluência em viga (MOTTA et al, 1996) 
Alguns ligantes, particularmente alguns modificados com polímero, podem exibir uma rigidez estática a baixa temperatura maior do que o desejado. Entretanto, estes podem não trincar devido à capacidade de deformar sem romper a baixa temperatura do polímero. Desta forma, a especificação permite que o ligante possua uma rigidez maior, desde que se comprove, através do teste de tração direta (Direct Tension Test - DDT), que este possui ductilidade suficiente a baixas temperaturas. A resposta do DDT é a tensão de deformação na fratura, que é medido a partir do estiramento de uma amostra, com formato de gravatinha, a baixa temperatura, até que esta rompa (Figura 2.10). De modo semelhante ao BBR, o DDT assegura que a resistência à ruptura do ligante, a baixa temperatura, seja minimizada (LEITE, 1999).
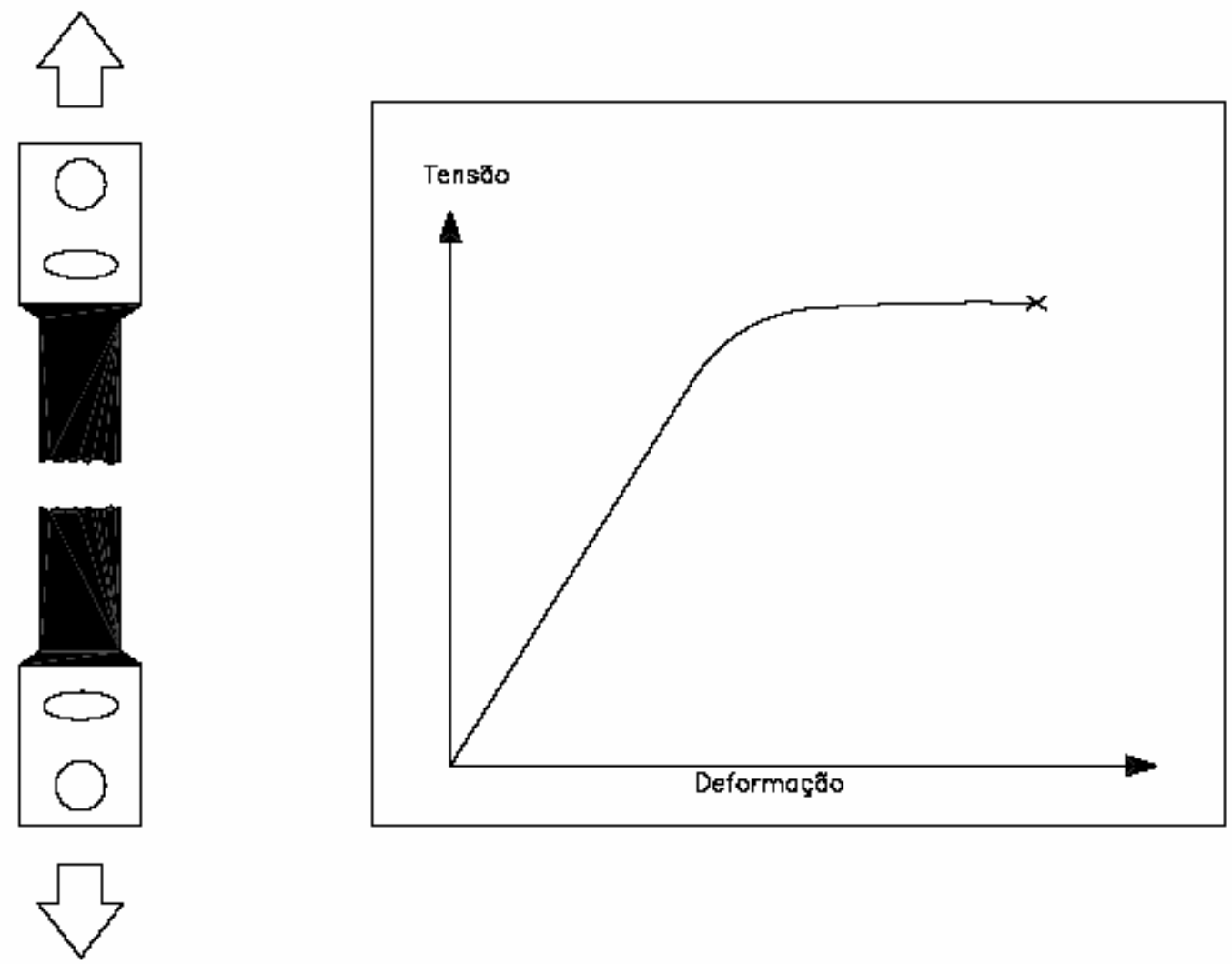

Figura 2.10 - Esquema do Teste da Tração Direta (LEITE, 1999)

O principal objetivo de se usar ensaios reológicos na especificação de ligantes é identificar correlações confiáveis entre as propriedades fundamentais dos ligantes asfálticos com o desempenho da mistura em serviço e, a partir desses ensaios, obter previsões da vida de fadiga, resistência à deformação permanente e resistência às 
trincas térmicas dos concretos asfálticos que são os defeitos estruturais predominantes nas pavimentações asfálticas.

$\mathrm{Na}$ especificação de ligantes baseada no desempenho (SHRP), o valor de $\mathrm{G}^{*} \operatorname{sen} \delta$ medido na faixa de viscoelasticidade linear, é usado para caracterizar o comportamento à fadiga do ligante. No entanto várias pesquisas em andamento têm criticado o uso desse parâmetro como um requisito para a previsão do desempenho das misturas em serviço (PLANCHE et al., 2003).

Hilde e Bernard (2000), pesquisadores do Nynas Petroleum, avaliaram um método para medir a resistência à fadiga de ligantes betuminosos utilizando o Reômetro de Cisalhamento Dinâmico - DSR. Foram realizados ensaios de fadiga a tensão controlada e a deformação controlada em ligantes originários de um mesmo cru, mas de diferentes consistência, além de asfaltos modificados por polímeros, com amostras virgens, com envelhecimento de curto prazo (após RTFOT) e com envelhecimento de longo prazo (RTFOT e PAV). Foi proposto um método que correlaciona o módulo complexo $\left(\mathrm{G}^{*}\right)$ e o tempo (número de ciclos), determinandose a vida de fadiga do ligante quando a rigidez $\left(\mathrm{G}^{*}\right)$ é reduzida em $50 \%$ de seu valor inicial. Todas as amostras foram ensaiadas com uma freqüência de $50 \mathrm{~Hz}$ e uma rigidez inicial de $20 \mathrm{MPa}$ para $\mathrm{G}^{*}$, sendo que as temperaturas foram adaptadas para cada ligante em função de sua consistência. Os asfaltos puros com diferentes valores de penetração apresentaram praticamente a mesma curva de fadiga, ensaiados com um mesmo valor do módulo complexo $G^{*}$. Não foi possível obter uma correlação aceitável com o parâmetro do SHRP para fadiga, $G^{*}$ sen $\delta$. Foi identificado uma boa correlação entre as curvas de fadiga dos ligantes puros e as curvas de fadiga das misturas ensaiadas sob as mesmas temperaturas, identificando-se um fator de 100 vezes entre as deformações do ligante e as deformações da mistura para uma mesma vida de fadiga assim como acontece entre as misturas ensaiadas em laboratório e as deformações reais em campo/serviço. No entanto são necessários estudos complementares de laboratório e validação de campo para demonstrar a acurácea destes ensaios medirem as propriedades relacionadas com o desempenho em serviço (VANELSTRAETE \& TEUGELS, 2003). 
A partir dos dados obtidos de uma pesquisa conjunta entre Nynas Bitumen e Belgian Road Research Centre desenvolvida com o objetivo de identificar um sistema de avaliação de desempenho para ligantes, várias parâmetros reológicos propostos na literatura foram estudados $\left(\delta, \mathrm{G}^{*}, 1 / \mathrm{G}^{*}, \mathrm{G}^{*} \operatorname{sen} \delta\right.$, $\tan \delta$, susceptibilidade ao cisalhamento da viscosidade e susceptibilidade ao cisalhamento do ângulo de fase) foram analisadas e nenhum destes parâmetros apresentou uma correlação aceitável com a fadiga da mistura (VANELSTRAETE \& TEUGELS, 2003).

Vários estudos têm mostrado a existência de boa correlação entre o parâmetro $\mathrm{G}^{*} / \operatorname{sen} \delta$ com a resistência à deformação permanente de misturas a altas temperaturas, com exceção para ligantes modificados por SBS que podem ter seu desempenho ao afundamento subestimados (DESMAZES et al., 2000). É importante salientar que a resistência a deformação permanente de uma dada mistura depende da composição total da mistura. Além do tipo e da quantidade do ligante, o esqueleto granular e a interação entre o ligante e o agregado são elementos importantes para a definição da resistência à deformação permanente, não sendo portanto suficiente apenas a indicação do comportamento do ligante (VANELSTRAETE \& TEUGELS, 2003).

Existem várias pesquisas em andamento que indicam outros critérios para especificar a resistência à deformação permanente como, por exemplo, a deformação acumulada e a viscosidade de cisalhamento zero podendo esta ser obtida a partir de ensaios de creep estático ou ensaios de compressão axial de carga repetida (HIR et al., 2003).

O ensaio com o reômetro de fluência em viga (BBR) é apropriado para a previsão do comportamento a baixas temperaturas, tanto para ligantes puros quanto para modificados por polímeros. A máxima temperatura resultante de $\mathrm{S}(\mathrm{s})=300 \mathrm{MPa}$ ou $\mathrm{m}(60 \mathrm{~s})=0,3$ pode ser usado como um indicador de desempenho adequado para este defeito (VANELSTRAETE \& TEUGELS, 2003). 


\subsection{Polímeros Modificadores de Asfalto}

Segundo Mano (1986), as moléculas que contém um número de átomos encadeados superior a uma centena são denominados macromoléculas. Tais moléculas adquirem características próprias que passam a predominar sobre as características inerentes a natureza dos átomos que as constituem. Essas propriedades decorrem de interações envolvendo segmentos da mesma macromolécula ou de outras.

O termo macromolécula definido anteriormente engloba os compostos de elevado peso molecular, considerando tanto os compostos que apresentam unidades químicas repetidas (polímeros), quanto os compostos de estruturas moleculares mais complexas (MANO, 1986).

Mano (1986) assinala que as propriedades especiais das macromoléculas, em geral, surgem a partir de um peso molecular entre 1000 e 1500, acentuando-as à medida que há crescimento deste valor.

“Os polímeros são substâncias macromoleculares, que podem ser produzidas pela natureza (madeira, óleo lubrificante, cortiça, etc) ou podem ser obtidos artificialmente pela união seqüenciada de pequenas moléculas, chamadas monômeros.

Os polímeros são classificados de inúmeras maneiras, de acordo com a finalidade classificatória. As principais são:

a) quanto à ocorrência: Naturais e Sintéticos;

b) quanto à preparação: Adição e Copolímeros;

c) quanto à cadeia: Homogêneos e Heterogêneos;

d) quanto à estrutura: Lineares ou Tridimensionais;

e) industrial: Elastômeros, Plásticos e Fibras.

Nos polímeros de adição (homopolímeros) apenas uma espécie de monômero é usado na polimerização. Na copolimerização (copolímero) são usados dois ou mais monômeros diferentes. Freqüentemente este tipo de produto apresenta melhores 
propriedades físicas e mecânicas, por esta razão, o completo domínio desta tecnologia foi um importante avanço na engenharia de construção.

Estruturalmente os polímeros são lineares (termo-sensíveis) e tridimensionais (termofixos). Monômeros bifuncionais geram polímeros lineares, enquanto os monômeros tri e tetrafuncionais geram os tridimensionais, caracterizado por uma estrutura espacial obtida pela interligação dessas unidades polifuncionais.

Quando as unidades químicas estão dispostas aleatoriamente na cadeia polimérica, têm-se os co-polímeros estatísticos. Em outro extremo, quando há um perfeito escalonamento entre os monômeros têm-se os copolímeros alternados. Os copolímeros em bloco alternam seqüências de unidades químicas iguais. Caso haja ramificações poliméricas na cadeia principal tem-se o copolímero enxertado ou grafitizado"(DNER, 1998). No caso do acoplamento de dois copolímeros em um terceiro existente tem-se o Terpolímero.

A Tabela 2.1 exemplifica as diversas configurações. 
Tabela 2.1 - Configuração dos polímeros

\begin{tabular}{|c|c|}
\hline Tipo & Configuração \\
\hline Monômero A & $\mathrm{A}$ \\
\hline Monômero B & $\mathrm{B}$ \\
\hline Monômero $\mathrm{C}$ & $\mathrm{C}$ \\
\hline Homopolímero & $\wedge^{\wedge \wedge \wedge} \mathrm{A}-\mathrm{A}-\mathrm{A}-\mathrm{A}-\mathrm{A}-\mathrm{A}-\mathrm{A}-\mathrm{A}-\mathrm{A}^{\wedge \wedge \wedge}$ \\
\hline Copolímero alternado & $\wedge^{\wedge \wedge \wedge} \mathrm{A}-\mathrm{B}-\mathrm{A}-\mathrm{B}-\mathrm{A}-\mathrm{B}-\mathrm{A}-\mathrm{B}-\mathrm{A}^{\wedge \wedge \wedge}$ \\
\hline Coplímero em Bloco & $\wedge^{\wedge \wedge \wedge} \mathrm{A}-\ldots-\mathrm{A}-\mathrm{B}-\ldots-\mathrm{B}-\mathrm{A}-\ldots-\mathrm{A}^{\wedge \wedge \wedge}$ \\
\hline Copolímero estatístico & $\wedge^{\wedge \wedge \wedge} \mathrm{A}-\mathrm{B}-\mathrm{B}-\mathrm{A}-\mathrm{A}-\mathrm{B}-\mathrm{A}-\mathrm{B}-\mathrm{A}^{\wedge \wedge \wedge}$ \\
\hline Copolímero Grafitizado & 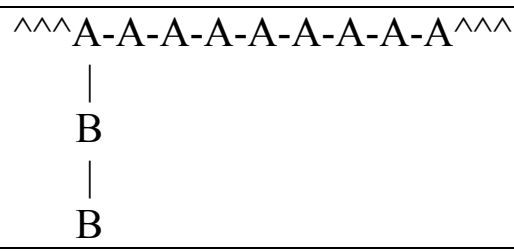 \\
\hline Terpolímero Grafitizado & $\begin{array}{cc}\wedge \wedge \wedge & \mathrm{A}-\mathrm{A}-\mathrm{A}-\mathrm{A}-\mathrm{A}-\mathrm{A}-\mathrm{A}-\mathrm{A}-\mathrm{A} \wedge \wedge \wedge \\
\mid & \mid \\
\mathrm{B} & \mathrm{C} \\
\mid & \mid \\
\mathrm{B} & \mathrm{C} \\
\end{array}$ \\
\hline
\end{tabular}

“Os polímeros termofixos ou termorrígidos não adquirem movimento plástico com o aumento da temperatura, mas podem perder resistência devido a ocorrência do fenômeno da degradação.

Já os polímeros termoplásticos, por apresentarem ligações intermoleculares fracas (Van der Waalls), que são facilmente superadas com a elevação da temperatura, permitem que a deformação ocorra por escorregamento nos pontos fracos das ligações entre as moléculas.

Um dos mais importantes efeitos do aumento da temperatura em um ligante asfáltico com polímero é o aumento da velocidade das reações químicas, como por exemplo, a ramificação e a reticulação. A temperatura na qual os polímeros ficam passíveis de sofrer reação química é aquela onde eles perdem sua resistência mecânica. Esta temperatura está sempre abaixo do ponto de fusão dos lineares e no começo da 
degradação dos tridimensionais (ou termofixos); por esta razão, os lineares podem ser reticulados.

Os polímeros termosensíveis se classificam industrialmente como : plásticos, fibras e elastômeros. Entretanto, no estudo da utilização de polímeros como melhoradores de asfalto, as classificações acadêmicas foram abandonadas e foi seguido um caminho mais objetivo, aparecendo classificações mais direcionadas ao meio rodoviário. A mais utilizada é a de Disnnem, que classifica os polímeros em quatro grupos distintos (DNER,1998):

a) Termorrígidos: são aqueles que não se fundem, degradam numa temperatura limite e endurecem irreversivelmente quando aquecidos a uma temperatura que depende de sua estrutura química. Cadeias moleculares formam rede tridimensional que resiste a qualquer mobilidade térmica (LEITE, 1999). Como exemplos, tem-se a resina epóxi, poliuretano, etc.

b) Termoplásticos: são aqueles que se fundem e se tornam maleáveis reversivelmente quando aquecidos. Normalmente consistem de cadeias lineares, mas podem ser também ramificadas. São incorporados aos asfaltos à alta temperatura (LEITE, 1999). Como exemplo, tem-se o polietileno, polipropileno atático e o policloreto de vinila.

c) Elastômeros: são aqueles que quando aquecidos se decompõem antes de amolecer, e apresentam propriedades elásticas que lembram a borracha. Como exemplo, tem-se o SBR, etc. (DNER, 1998)

d) Elastômero-termoplásticos: são aqueles que ao serem aquecidos se comportam como termoplásticos, mas em temperaturas mais baixas apresentam propriedades elásticas. Como exemplos, tem-se o SBS e o RET. (DNER, 1998) 


\subsubsection{Polímero SBR}

O polímero SBR é um copolímero aleatório de estireno e butadieno, obtido principalmente por processo de polimerização em emulsão. Apresentam propriedades elastoméricas de resiliência e boa compatibilidade com os betumes. Suas propriedades mecânicas são intrinsecamente baixas, porém podem ser grandemente melhoradas com a vulcanização, que é conseguida pela reação com enxofre ou peróxidos. O processo de preparação do SBR em emulsão produz um polímero finamente dividido, na forma de um látex, que facilita sua dispersão no asfalto. A técnica de dispersão do látex pode também ser utilizada a partir de borracha natural. (LEITE, 1999)

Atualmente no Brasil o polímero SBR tem sido muito utilizado para a fabricação de emulsões modificadas por polímeros.

\subsubsection{Polímero EVA}

O polímero EVA é um copolímero de etileno e acetato de vinila cuja composição pode variar de uns poucos por cento de acetato até cerca de $50 \%$. De acordo com esta proporção, as propriedades variam de um termoplástico muito semelhante ao polietileno de baixa densidade até um elastômero. Os segmentos de etileno são semicristalinos, enquanto os que contém os grupos acetato constituem a fase amorfa, conforme a Figura 2.11. Suas maiores vantagens são a resistência à flexão e a estabilidade térmica, aliadas a um custo razoável. (LEITE, 1999)

Nestes copolímeros a redução do teor de acetato de vinila acarreta aumento da cristalinidade e, em conseqüência, do módulo de rigidez, das temperaturas de amolecimento e de fusão e a diminuição da temperatura de fragilidade. É dito um termoplástico plastômero, ou seja, escoa irreversivelmente quando se aplica uma tensão cisalhante, pois não possui reticulação como SBR. O EVA se solubiliza nas frações saturadas devido a sua natureza alifática em virtude da existência de 
seqüências etilênicas de elevado peso molecular, modificando o escoamento do material (LEITE, 1999).

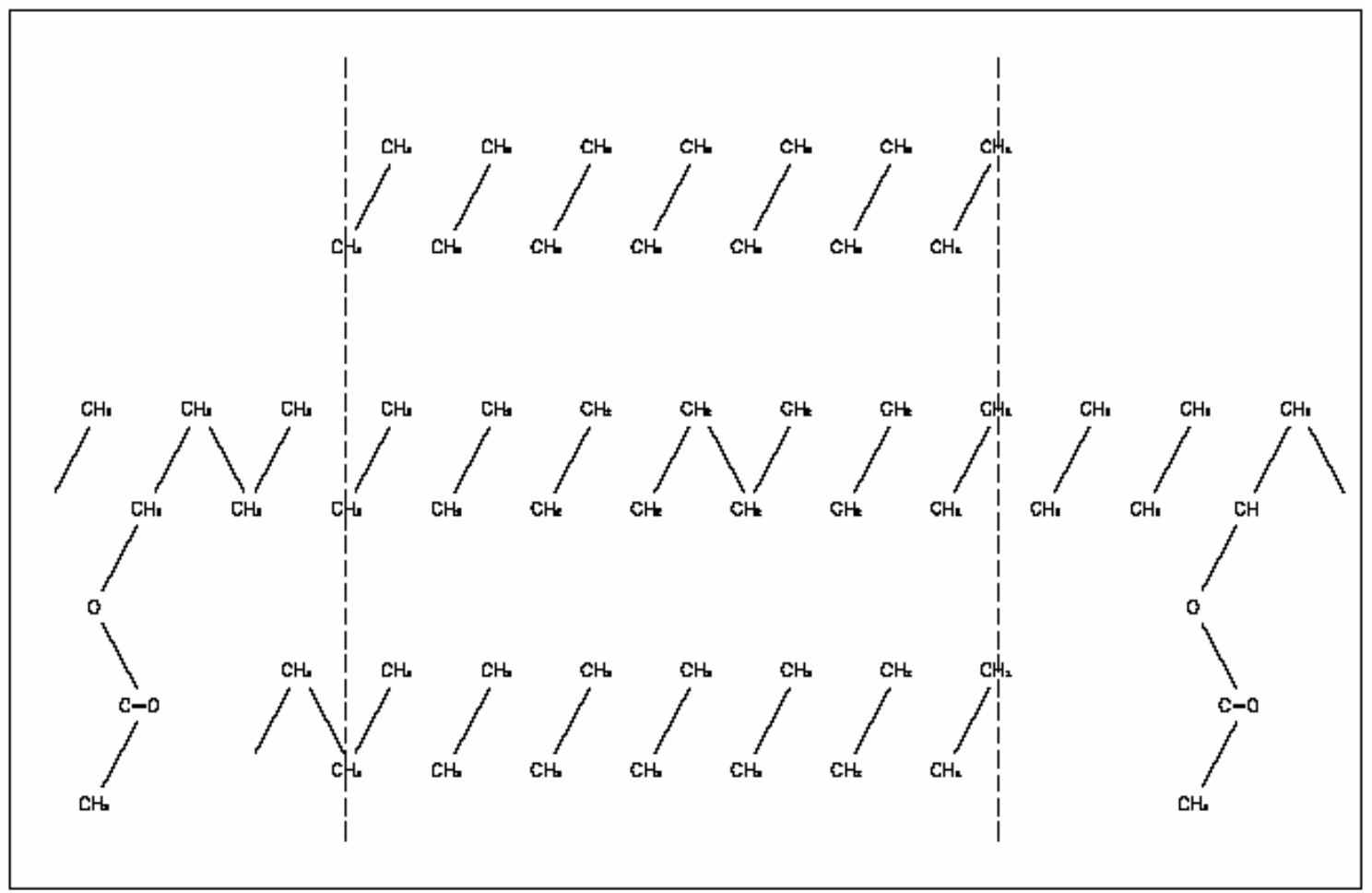

Figura 2.11 - Conformação planar das moléculas de EVA (LEITE, 1999)

Segundo Freitas (1996) o EVA como modificador de ligantes é muito utilizado em alguns países, destacando-se, por exemplo, a França e a Espanha.

\subsubsection{Polímero SBS}

O copolímero SBS pode ser obtido sob diferentes formas estruturais, dependendo da natureza dos co-monômeros e do tipo de associação entre eles, tais como: lineares e radiais. Os lineares podem ser obtidos de forma seqüencial distinta, como: estatístico, alternado e seqüenciado (RAMOS, 1995).

O tipo de SBS mais usado no mundo para modificação do asfalto é o seqüenciado, obtido pelo acoplamento de duas extremidades poliestirênicas e uma longa seqüência butadiênica. Como a seqüência butadiênica tem forma enovelada, o conjunto se 
apresenta na forma de verdadeiro "halteres" como visto na Figura 2.12 (DNER, 1998).

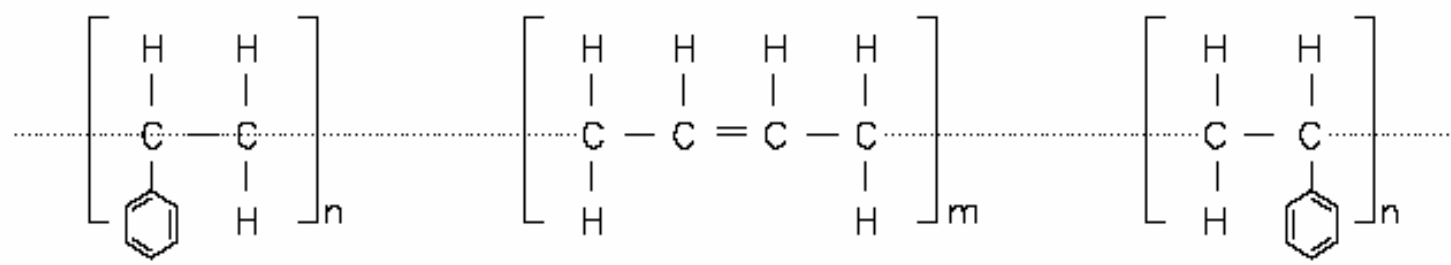

Figura 2.12 - Representação do Polímero SBS (DNER, 1998)

A molécula de SBS é dividida em regiões de natureza química completamente diferentes: nas duas extremidades as regiões são de caráter aromático e a longa cadeia butadiênica é de caráter alifático. Em virtude disso, os conjuntos de moléculas de SBS, para diminuírem a energia livre total, precisam evitar o contato aromáticoalifático, para o que se ligam pelas extremidades estirênicas, formando conjuntos que se comportam como verdadeiros “domínios” aromático e alifático (DNER, 1998).

A ligação das extremidades estirênicas formando os "domínios" aromáticos, funciona como uma verdadeira vulcanização, o que garante ao produto excelentes características mecânicas sem nenhum prejuízo de sua altíssima elasticidade entrópica de conformação. 


\subsection{Polímero do Tipo RET}

O polímero RET, que em português quer dizer Terpolímero Elastomérico Reativo, é relativamente novo e projetado especificamente para a modificação de asfaltos. $\mathrm{O}$ desenvolvimento do polímero se deu a partir de 1988 quando se buscou um modificador de asfalto que pudesse ser facilmente incorporado e cujas propriedades viscoelásticas fossem similares a de asfaltos com outros modificadores utilizados como os Copolímeros de Estireno Butadieno (NEGRÃO et al., 2005).

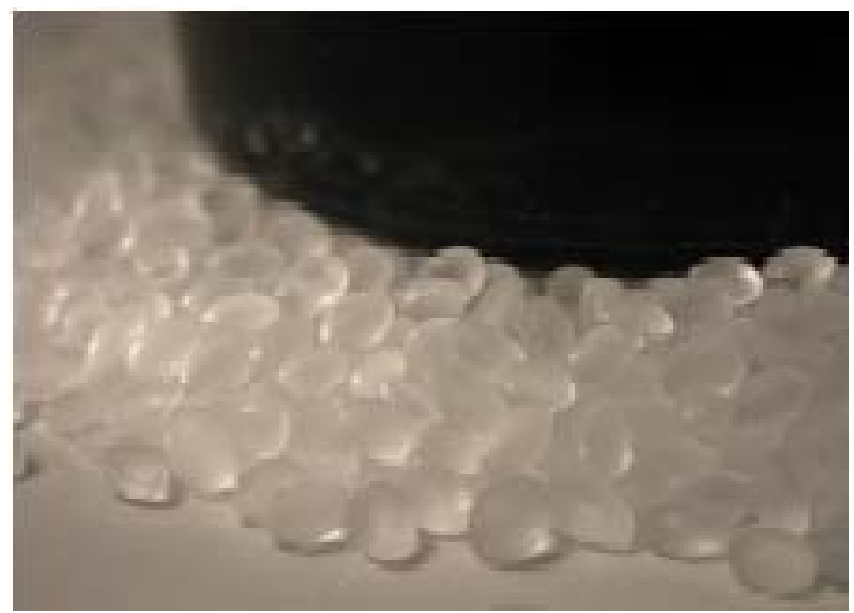

Figura 2.13 - Polímero do tipo RET

Em 1989 foi desenvolvido o primeiro polímero do tipo RET de reação lenta e a partir de 1991 inicia-se a pavimentação de trechos experimentais nos Estados Unidos. De 1994 até os dias de hoje, foram desenvolvidos vários tipos de polímeros RET, entre eles o de alta reação com catalisador, que atualmente se utiliza no Brasil (NEGRÃO et al., 2005).

\subsubsection{Química do Polímero RET}

O RET é um polímero cuja composição se diferencia dos elastômeros formados por blocos de estireno - butadieno. Como o próprio nome já diz, ele é um "Terpolímero", ou seja, é um polímero formado por três monômeros, sendo eles a coluna de Etileno, 
o n-Butil Acrilato e o Glicidil Metacrilato. Sua estrutura química é apresentada na Figura 2.14.

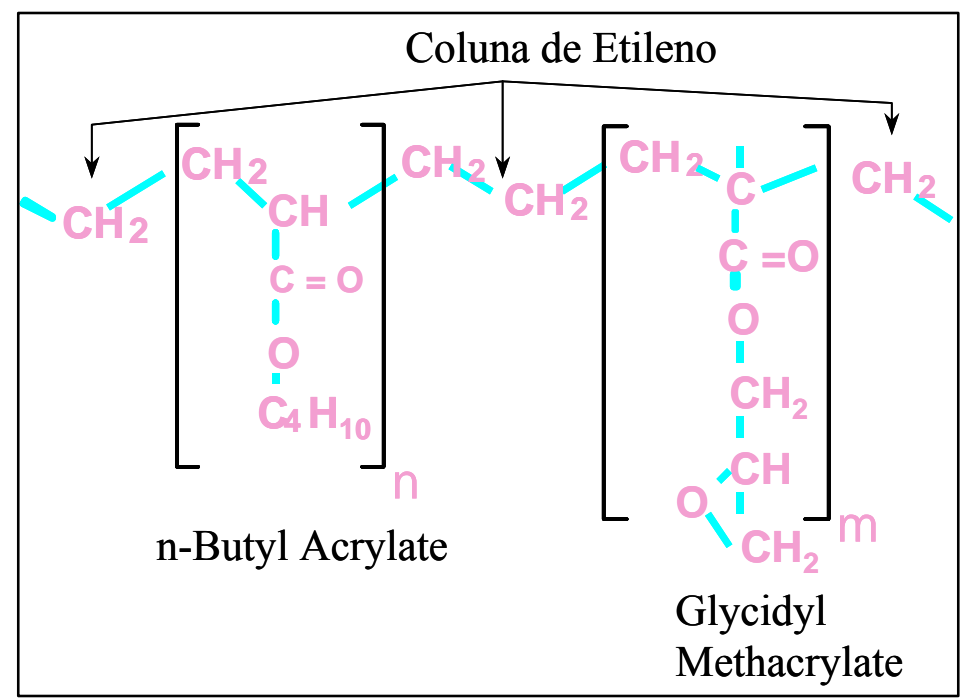

Figura 2.14 - Representação do Polímero RET ${ }^{1}$

No seu nome também temos a palavra "Reativo", pois sua distribuição química faz com que ele reaja quimicamente com os asfaltenos do asfalto para formar um composto inseparável. A reação entre o RET e o asfalteno é representada na Figura 2.15 .

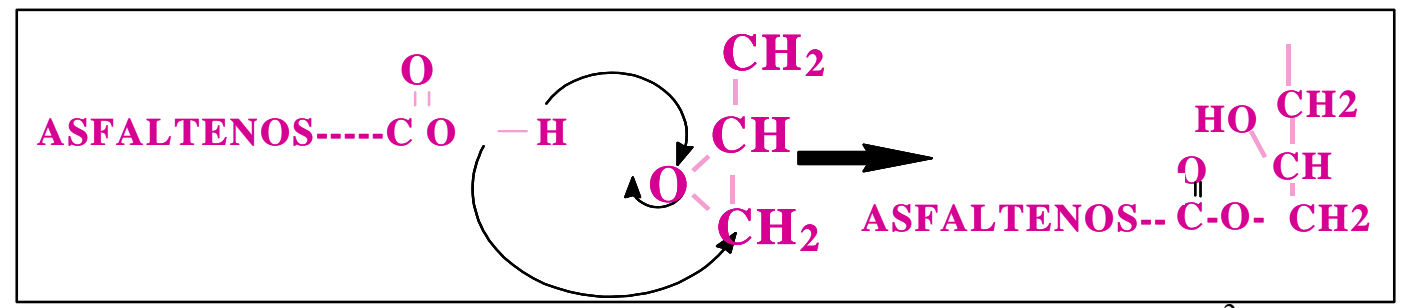

Figura 2.15 - Reação do Asfalteno com Polímero do Tipo RET ${ }^{2}$

Nota-se que a reação entre o polímero RET e o asfalteno se dá através do copolímero Glicidil Metacrilato e ainda que esta é uma reação de adição e, portanto, não gera sub-produtos como vapor d'água ou gases voláteis. As figuras 2.16 e 2.17 foram obtidas com um microscópio eletrônico, sendo que a primeira ilustra uma amostra de

\footnotetext{
${ }^{1}$ Apresentação da Du Pont, realizada em power point.

${ }^{2}$ Apresentação da Du Pont, realizada em power point.
} 
asfalto modificado com polímero não reativo e a segunda um asfalto modificado com polímero RET (NEGRÃO et al., 2005).

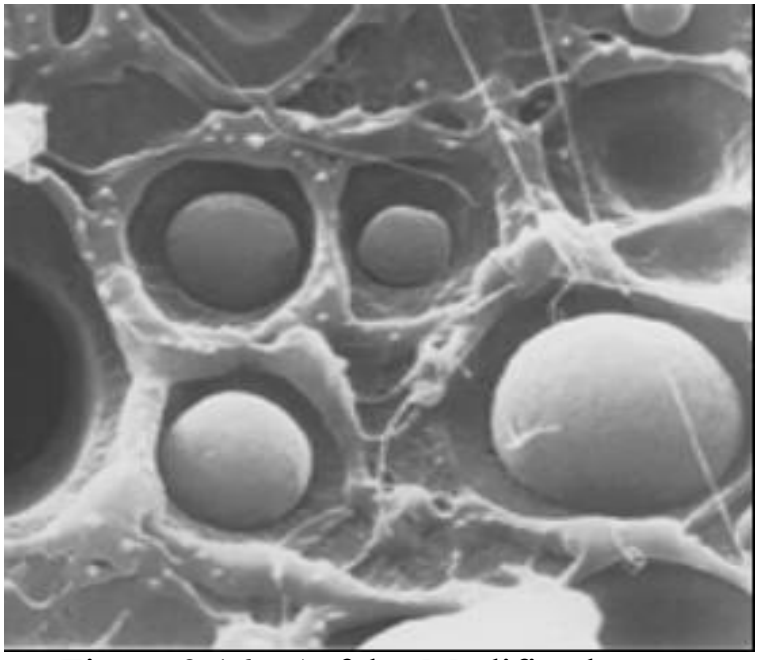

Figura 2.16 - Asfalto Modificado com polímero não reativo, por ser uma modificação mecânica existe a possibilidade de segregação

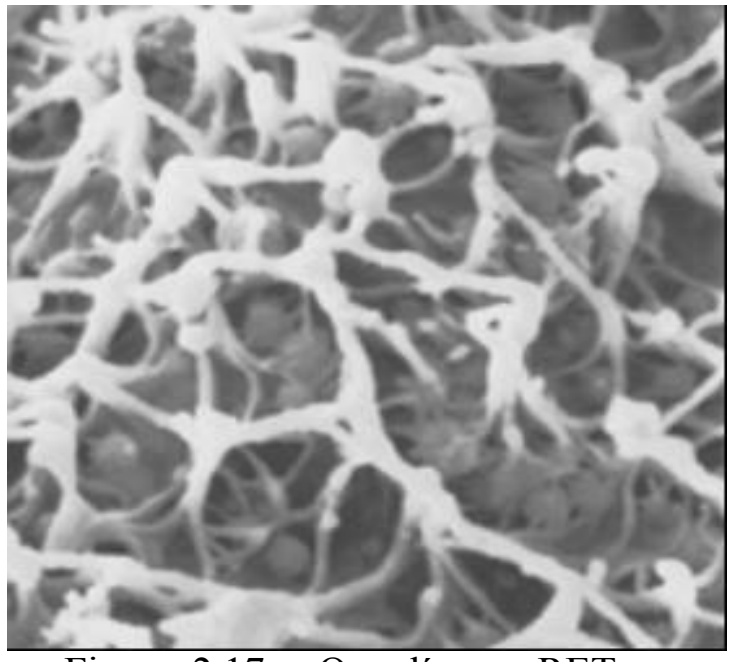

Figura 2.17 - O polímero RET se mistura fisicamente com o asfalto evitando futuras separações

\subsubsection{Características dos Asfaltos Modificados por Polímero do Tipo RET}

Segundo a Task Force 31 da AASTHO, o RET é classificado como polímero do TIPO I (Elastomérico) e a sua utilização, bem como a utilização de qualquer outro polímero do TIPO I na modificação de ligantes asfálticos, tem como objetivo a melhoria das seguintes características:

I. Diminuição da suscetibilidade térmica (a consistência do asfalto modificado permanece inalterada sob larga faixa de temperaturas. Em clima frio, seu caráter flexível aumenta a resistência às trincas e fissuras na superfície do revestimento. Em clima quente, o incremento do ponto de amolecimento e da viscosidade do ligante reduz o risco de exsudação, afundamentos em trilhas de roda e perda da macrotextura do revestimento);

II. Melhor característica adesiva e coesiva (aumenta a resistência à desagregação do pavimento. A resistência coesiva faz com que o ligante asfáltico mantenha 
os agregados unidos, quando sujeitos à ação das cargas de tráfego, em especial nas baixas temperaturas);

III. Maior resistência ao envelhecimento (aumenta a vida útil do ligante);

IV. Elevação do Ponto de Amolecimento - PA (diminui a deformação permanente);

V. Diminuição do Ponto de Ruptura Fraass - PF, temperatura em que o asfalto sofre trincas quando submetido à tensão (diminui as trincas térmicas);

VI. Aumento do intervalo de plasticidade, faixa de temperatura na qual o asfalto pode ser utilizado (conseqüência do Ponto de Amolecimento elevado e Ponto de Ruptura Fraass baixo);

VII. Maior resistência à deformação permanente (aumento da elasticidade);

VIII. Excelente comportamento reológico (a resistência à fluência e/ou boa recuperação elástica do ligante modificado sob tensões de tração mantém a integridade do revestimento, mesmo quando sujeito a níveis elevados de carga e deslocamento).

\subsubsection{Processo de Modificação do Asfalto com o Polímero do Tipo RET}

O processo de modificação do asfalto com o polímero RET é bastante simples e pode ser dividido em cinco etapas, a saber (NEGRÃO et al, 2005):

1. Aquecimento do asfalto (de 185 a $\left.195^{\circ} \mathrm{C}\right)$;

2. Adição do polímero (de $1 \%$ a $2 \%$ em peso do asfalto);

3. Homogeneização do polímero no asfalto (agitação por duas horas);

4. Adição do Catalisador $\mathrm{H}_{3} \mathrm{PO}_{4}(0,22 \%$ em peso do asfalto, independente da quantidade do polímero);

5. Finalização da reação (agitação por uma hora e meia). 
Observa-se que depois do passo 1 o processo tem a duração de quatro a cinco horas, dependendo da quantidade de asfalto a ser modificada e da reatividade do asfalto base. Para modificação em laboratório, os tempos de agitação são diferentes, conforme detalhado no capítulo do estudo realizado em laboratório.

Como a incorporação do polímero do Tipo RET depende, além dos insumos, apenas de aquecimento e de agitação simples a mesma pode ser realizada in loco na própria usina instalada para a produção da mistura asfáltica. Para tanto, deve-se adaptar um dos tanques de armazenamento de CAP da usina com dois funis para a adição do polímero e dois agitadores para a homogeneização da mistura (Figuras 2.18e 2.19).

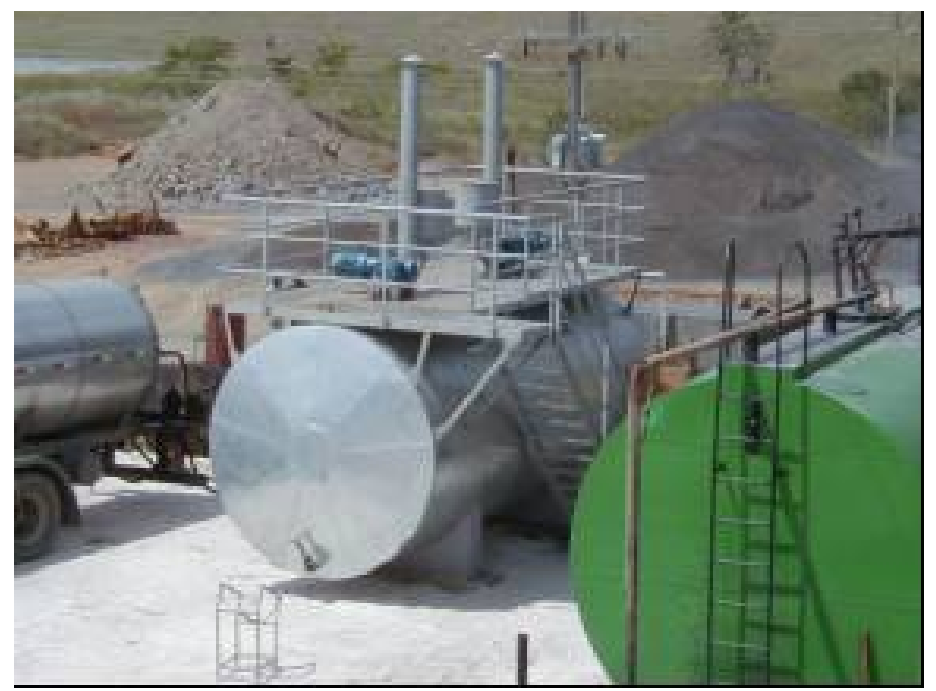

Figura 2.18 - Tanque de Modificação Instalado em Obra

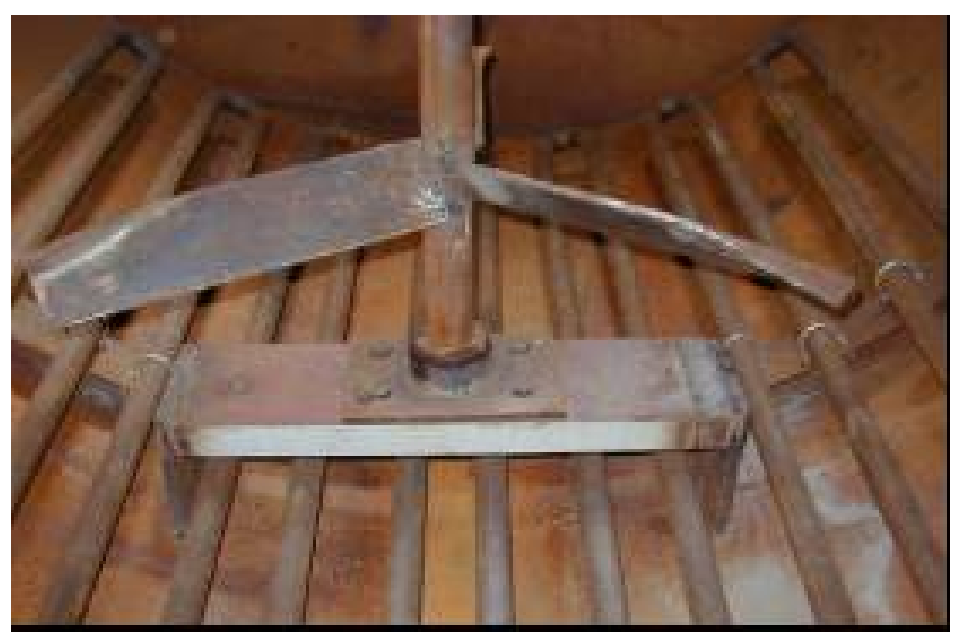

Figura 2.19 - Detalhe do Agitador dentro do Tanque

Uma vez modificado o asfalto não necessita de temperatura mínima e nem de agitação para manter-se armazenado ou transportado, visto que o polímero está 
quimicamente incorporado. Desta forma pode-se transferir o ligante modificado para outro tanque dando espaço para uma nova modificação (NEGRÃO et al., 2005).

\subsubsection{Estudo da Federal Highway Administration com o Polímero RET}

Segundo estudo realizado pela Federal Highway Administration nos Estados Unidos da América o polímero RET, comercializado pela DuPont sob o nome comercial de ELVALOY $^{\circledR}$, foi o que apresentou a maior resistência à deformação permanente e o melhor comportamento ao dano causado pela umidade quando comparado a diversos tipos de asfaltos estudados (modificados ou não). Os ligantes estudados foram os seguintes:

- PG64: Ligante sem modificação com características que se aproximam do CAP20 da especificação brasileira;

- ESI: ligante modificado com ethylene-styrene-interpolymer;

- EVA Grafted: ligante modificado por polímero Eva Grafitizado;

- SBS Linear: ligante modificado por polímero SBS Linear;

- EVA: ligante modificado por polímero EVA;

- SBS Radial Grafted: ligante modificado com polímero SBS Radial Grafitizado;

- SBS Grafted: ligante modificado por polímero SBS Grafitizado;

- PG70: Ligante sem modificação com características que se aproximam do CAP40 da especificação brasileira;

- CMCRA: ligante com borracha incorporada quimicamente;

- ELVALOY $^{\circledR}$ : ligante modificado por polímero do tipo RET (Elvaloy $\left.{ }^{\circledR}\right)$;

- Air Blown: asfalto soprado.

O ensaio utilizado para determinar a resistência à deformação permanente e verificar os danos causados pela umidade é conhecido como Teste de Hamburgo (Figuras 2.20 e 2.21). Este ensaio consiste em moldar uma amostra da mistura a ser ensaiada e, através de uma roda presa a um eixo, aplicar ciclos de carga na amostra. Ao longo 
dos ciclos deve-se medir a deformação causada na amostra em mm. Quando o objetivo é verificar a resistência da amostra na presença da umidade a amostra é ensaiada submersa em água.

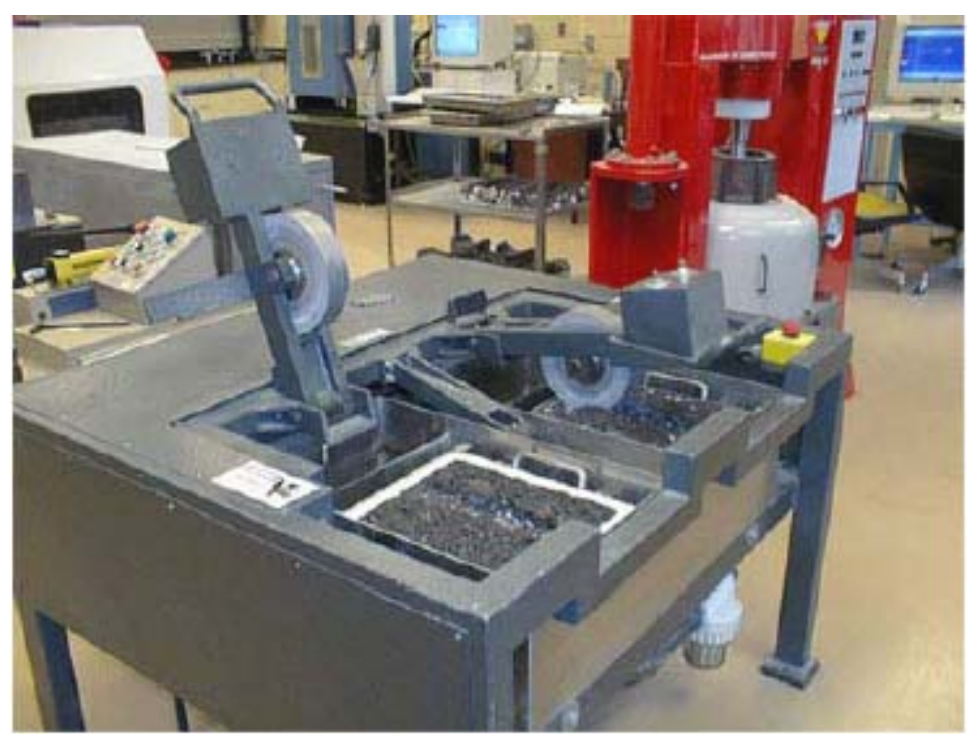

Figura 2.20- Teste de Hamburgo

O gráfico com o resultado encontrado no estudo é apresentado na figura 2.21.

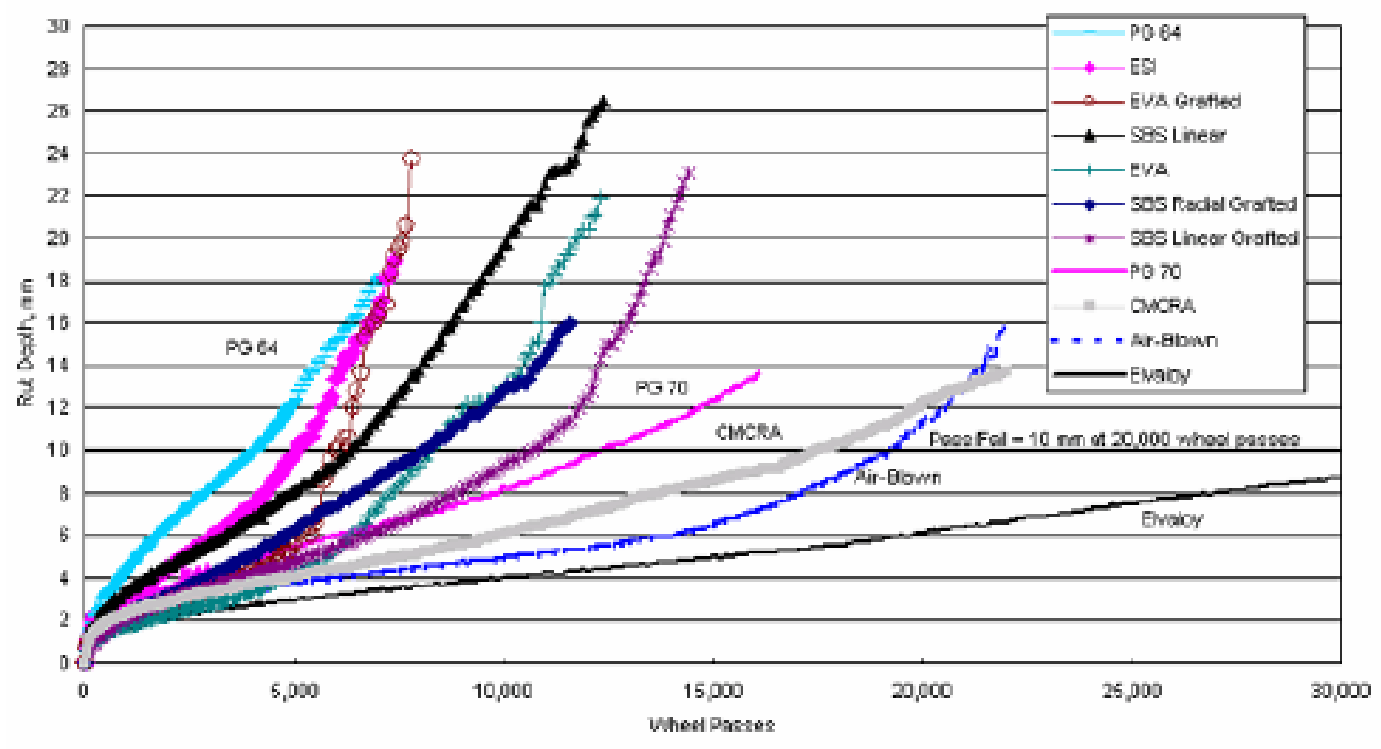

Figure 2. Dax cepth ve. whesl paeses fram the Hamburg WTD at $53 \cdot \mathrm{C}$.

Figura 2.21- Gráfico da Deformação Permanente (Teste de Hamburgo) 
As conclusões apresentadas pelo estudo foram as seguintes:

- Baseado no número de passadas do eixo necessárias para obter uma trilha de roda de $10 \mathrm{~mm}$, somente a mistura executada com polímero RET teve um desempenho significativamente superior à amostra de controle (PG 70-22) (FHWA, 2001);

- A mistura executada com polímero do tipo RET foi a única que não foi suscetível à umidade (FHWA, 2001);

\subsubsection{Experiências do Polímero do Tipo RET no Brasil}

O Polímero do tipo RET foi introduzido no mercado brasileiro no segundo semestre de 2002 e, nesta ocasião, foi executado em um segmento experimental na SP-330 Rodovia Anhanguera, a qual é administrada pela concessionária AutoBAn e é objeto de estudo mais detalhado apresentado no capítulo 5 desta dissertação.

Desde então foram executados uma série de segmentos rodoviários totalizando, aproximadamente, quatro milhões e quinhentos mil metros quadrados de misturas asfálticas aplicadas com asfalto modificado por polímero do tipo RET, sendo estes segmentos listados na Tabela 2.2.

Tabela 2.2 - Segmentos Executados com Polímero do Tipo RET

\begin{tabular}{|c|c|c|c|}
\hline Rodovia & Segmento & $\begin{array}{c}\text { Extensão } \\
\text { (km) }\end{array}$ & Tipo de Mistura Utilizada \\
\hline BR-153/GO & $\mathrm{Km} 605,8$ ao km 675,6 & 69,8 & BINDER / CBUQ Faixa"C" \\
\hline BR-116/CE & $\mathrm{Km} 314,6$ ao $\mathrm{km} \mathrm{418,0}$ & 103,4 & CBUQ Faixa "C" \\
\hline BR-101/BA & $\mathrm{Km} \mathrm{703,5} \mathrm{ao} \mathrm{km} \mathrm{785,5}$ & 82,0 & CBUQ Faixa "C" \\
\hline BR-116/CE & $\mathrm{km} 11,8$ ao km 26,8 & 15,0 & CPA \\
\hline BR-153/GO & $\mathrm{km} 0$ ao km 212,4 & 212,4 & CBUQ Faixa "C" \\
\hline BR-381/MG & $\mathrm{Km} \mathrm{224,0}$ ao km 244,0 & 20,0 & BINDER / SMA \\
\hline SP-300 & km 317 ao km 348 & 31,0 & CBUQ Faixa "C" \\
\hline
\end{tabular}


Conforme citado anteriormente o asfalto modificado por polímero do tipo RET é produzido na própria usina que confecciona a mistura asfáltica. O mapa da Figura 2.22 apresenta a localização dos tanques existentes no país capazes de modificar asfalto com este tipo de polímero no presente momento.

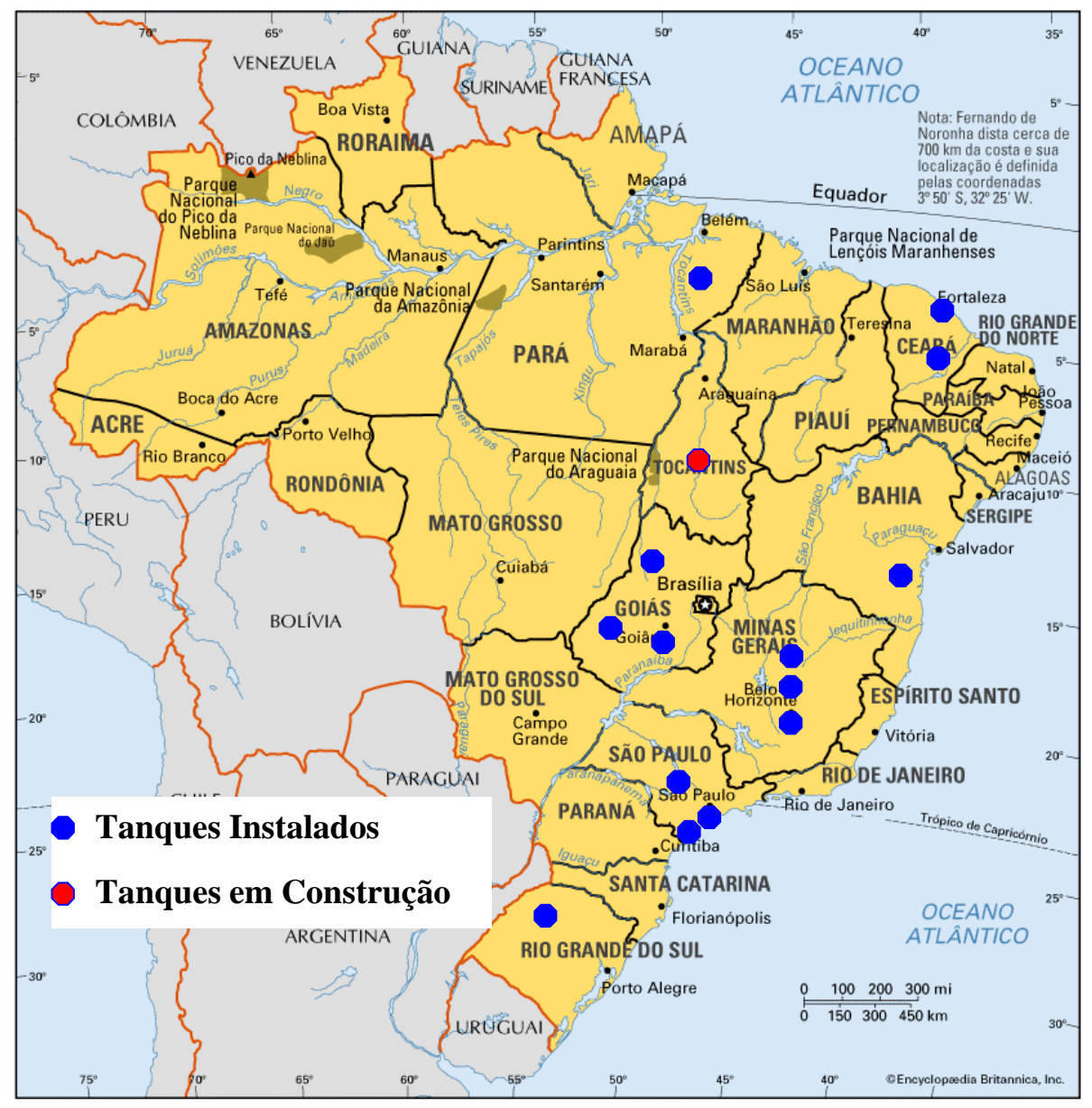

Figura 2.22- Tanques de Modificação de Asfalto no Brasil 


\section{MATERIAIS E MÉTODOS}

Este capítulo trata das características dos agregados e dos cimentos asfálticos selecionados para os ensaios laboratoriais e para a execução do trecho experimental da Rodovia Anhanguera, sendo apresentados métodos e procedimentos laboratoriais e de campo empregados durante a presente pesquisa.

\subsection{ESTUDO EM LABORATÓRIO}

\subsubsection{Agregados}

\subsubsection{Origem}

Neste estudo foram empregados agregados de natureza mineral basáltica, proveniente da Pedreira Basalto 5, localizada no km 2,3 da SP-101 em Hortolândia, estado de São Paulo. Por se tratar de um agregado de boas características físicas e mecânicas e de uso intensivo na região, este agregado foi escolhido para compor a presente pesquisa.

Os materiais britados foram coletados diretamente dos estoques da pedreira a partir de diversos pontos da pilha de modo a se obter uma amostra representativa do material (DNER-PRO 120/97). A redução das amostras em laboratório foi realizada com a utilização do separador mecânico (DNER-PRO 199/96).

\subsubsection{Análise Granulométrica}

Para composição da curva granulométrica do projeto foram selecionadas três frações: brita $1(19 \mathrm{~mm})$, pedrisco $(12,5 \mathrm{~mm})$, pó de pedra $(4,8 \mathrm{~mm})$. As características granulométricas dos agregados graúdos e miúdos são apresentadas na Tabela 3.1 e na Figura 3.1 
Tabela 3.1 - Análise Granulométrica dos Agregados

\begin{tabular}{|c|c|c|c|c|}
\hline \multicolumn{2}{|c|}{ PENEIRA } & BRITA 1 & PEDRISCO & PO DE PEDRA \\
\hline Abertura (mm) & Poleg./N & \multicolumn{3}{|c|}{ (\% que passa) } \\
\hline 19,0 & $3 / 4$ & 100,0 & - & - \\
12,5 & $1 / 2$ & 39,3 & 100,0 & - \\
9,52 & $3 / 8$ & 4,7 & 98,3 & 100,0 \\
4,80 & 4 & 1,1 & 20,5 & 98,4 \\
2,00 & 10 & 1,0 & 0,6 & 70,0 \\
0,42 & 40 & 0,9 & 0,3 & 34,4 \\
0,175 & 80 & 0,7 & 0,2 & 24,6 \\
0,075 & 200 & 0,5 & 0,2 & 13,9 \\
\hline
\end{tabular}

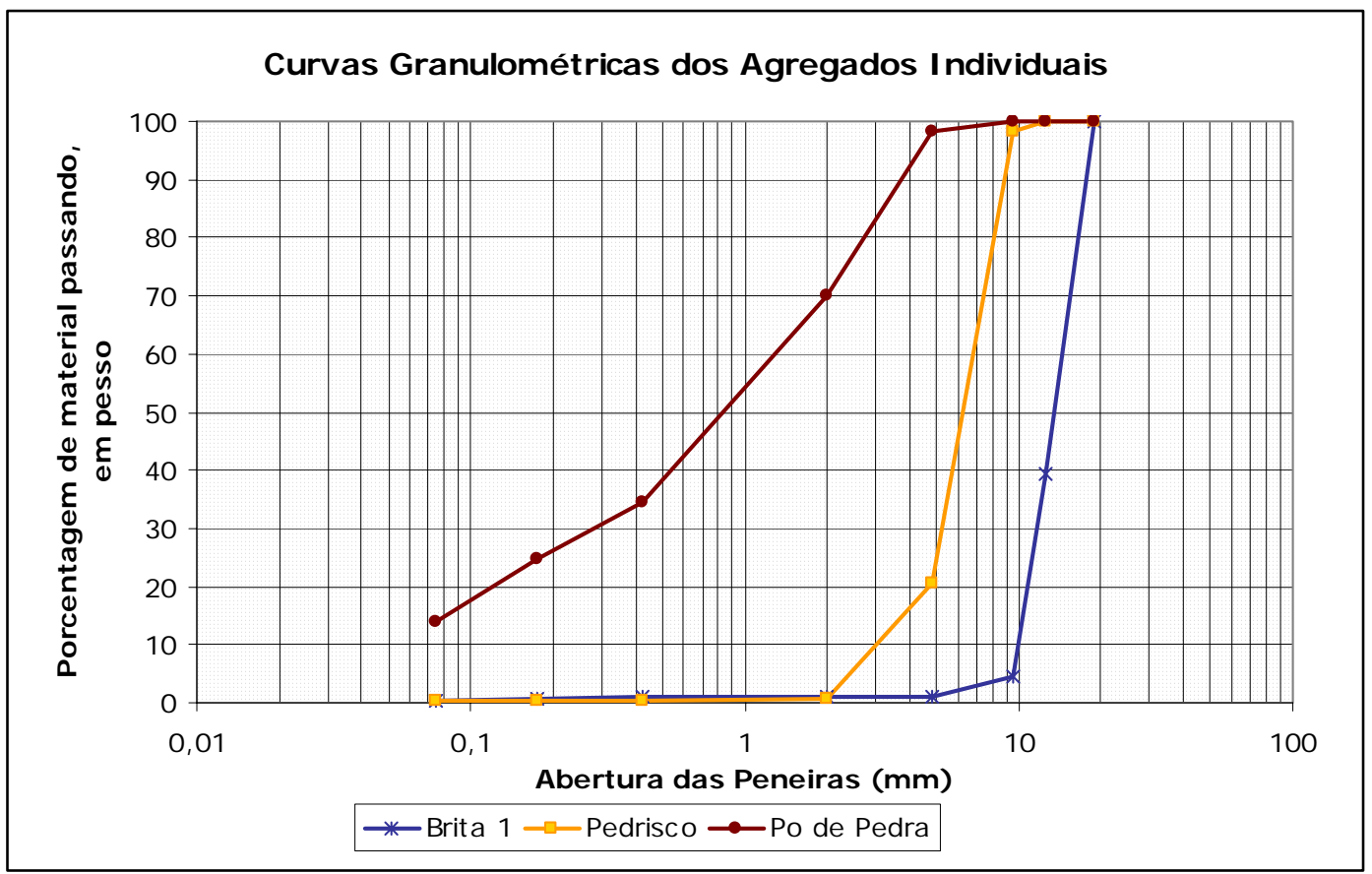

Figura 3.1 - Curvas Granulométricas dos Agregados Empregados

\subsubsection{Características dos Agregados}

Foram realizados ensaios físicos e mecânicos previstos nas especificações brasileiras de forma a garantir a completa caracterização dos agregados empregados na pesquisa. Os resultados encontrados classificam o material como de boa qualidade para aplicação em misturas asfálticas, tendo em vista seus baixos valores de Abrasão 
Los Angeles (em torno de 13\%) e praticamente inexistência de partículas planas e alongadas. O resumo dos resultados encontrados é apresentado na Tabela 3.2.

De modo geral os ensaios são de uso corrente e não apresentaram grandes dificuldades para sua realização conforme os procedimentos normatizados. Relaciona-se a seguir os ensaios $\mathrm{e}$ as respectivas normas empregadas na determinação das propriedades físicas e mecânicas dos agregados utilizados neste estudo:

a) Granulometria (DNER 083/94)

e) Abrasão Los Angeles (DNER ME 035/94)

f) Equivalente Areia (DNER ME 054/94)

g) Durabilidade Frente ao Sulfato de Sódio (DNER ME 089/94)

i) Índice de Forma (DNER ME 086/94)

j) Índice de Plasticidade (DNER ME 082/94)

h) Limite de Liquidez (DNER ME 122/94)

Tabela 3.2: Características do Agregado Estudado

\begin{tabular}{|l|c|c|c|}
\hline \multicolumn{1}{|c|}{ Ensaio } & \multicolumn{1}{|c|}{ Método } & Obtido & Especificado \\
\hline Abrasão Los Angeles & DNER ME 035/94 & $13 \%$ & $<50 \%$ \\
\hline $\begin{array}{l}\text { Equivalente de Areia (sem cal) } \\
\begin{array}{l}\text { Durabilidade Frente ao Sulfato de } \\
\text { Sódio (Brita 1 e Pedrisco) }\end{array}\end{array}$ & DNER ME 054/94 & $56,5 \%$ & $>55 \%$ \\
$\begin{array}{l}\text { Durabilidade Frente ao Sulfato de } \\
\text { Sódio (Pó de Pedra) }\end{array}$ & DNER ME 089/94 & $0,90 \%$ & $<18 \%$ \\
$\begin{array}{l}\text { Índice de Forma (Brita 1) } \\
\text { Índice de Plasticidade }\end{array}$ & DNER ME 086/94 & $0,73 \%$ & $>0,5 \%$ \\
\hline Limite de Liquidez & DNER ME 082/94 & NP & $<6,0 \%$ \\
\hline
\end{tabular}




\subsubsection{Escolha da Curva Granulométrica}

A curva granulométrica foi escolhida em função da mistura utilizada no trecho experimental da Rodovia Anhanguera que tem uso corrente pelas concessionárias de rodovias no estado de São Paulo. A curva selecionada enquadra-se na Faixa III do DERSA (Desenvolvimento Rodoviário AS). São apresentados na Tabela 3.3 e na Figura 3.2 os percentuais dos agregados, a curva granulométrica de projeto e a Faixa III do DERSA.

Tabela 3.3 - Analise Granulométrica dos Agregados

\begin{tabular}{|c|c|c|c|c|c|c|}
\hline \multicolumn{2}{|c|}{ PENEIRA } & \multirow{2}{*}{ BRITA 1} & \multirow{2}{*}{ PEDRISCO } & \multirow{2}{*}{$\begin{array}{l}\text { PO DE } \\
\text { PEDRA }\end{array}$} & \multirow{4}{*}{$\begin{array}{c}\text { GRANUL. } \\
\text { OBTIDA } \\
(\%)\end{array}$} & \multirow{4}{*}{$\begin{array}{l}\text { Especificação } \\
\text { DERSA ET- } \\
\text { P00/027FIII }\end{array}$} \\
\hline \multirow{3}{*}{$\begin{array}{c}\text { Abertura } \\
\mathrm{mm}\end{array}$} & \multirow{3}{*}{$\begin{array}{l}\text { Poleg./ } \\
\mathrm{N}\end{array}$} & & & & & \\
\hline & & $21,0 \%$ & $22,0 \%$ & $57,0 \%$ & & \\
\hline & & \multicolumn{3}{|c|}{ (\% que passa) } & & \\
\hline 19,0 & $3 / 4$ & 100,0 & - & - & 100,0 & 100 \\
\hline 12,5 & $1 / 2$ & 39,3 & 100,0 & - & 87,3 & $80-100$ \\
\hline 9,52 & $3 / 8$ & 4,7 & 98,3 & 100,0 & 79,6 & $70-90$ \\
\hline 4,80 & 4 & 1,1 & 20,5 & 98,4 & 60,8 & $50-70$ \\
\hline 2,00 & 10 & 1,0 & 0,6 & 70,0 & 40,2 & $33-48$ \\
\hline 0,42 & 40 & 0,9 & 0,3 & 34,4 & 19,8 & $15-25$ \\
\hline 0,175 & 80 & 0,7 & 0,2 & 24,6 & 14,2 & $8-17$ \\
\hline 0,075 & 200 & 0,5 & 0,2 & 13,9 & 8,1 & $4-10$ \\
\hline
\end{tabular}




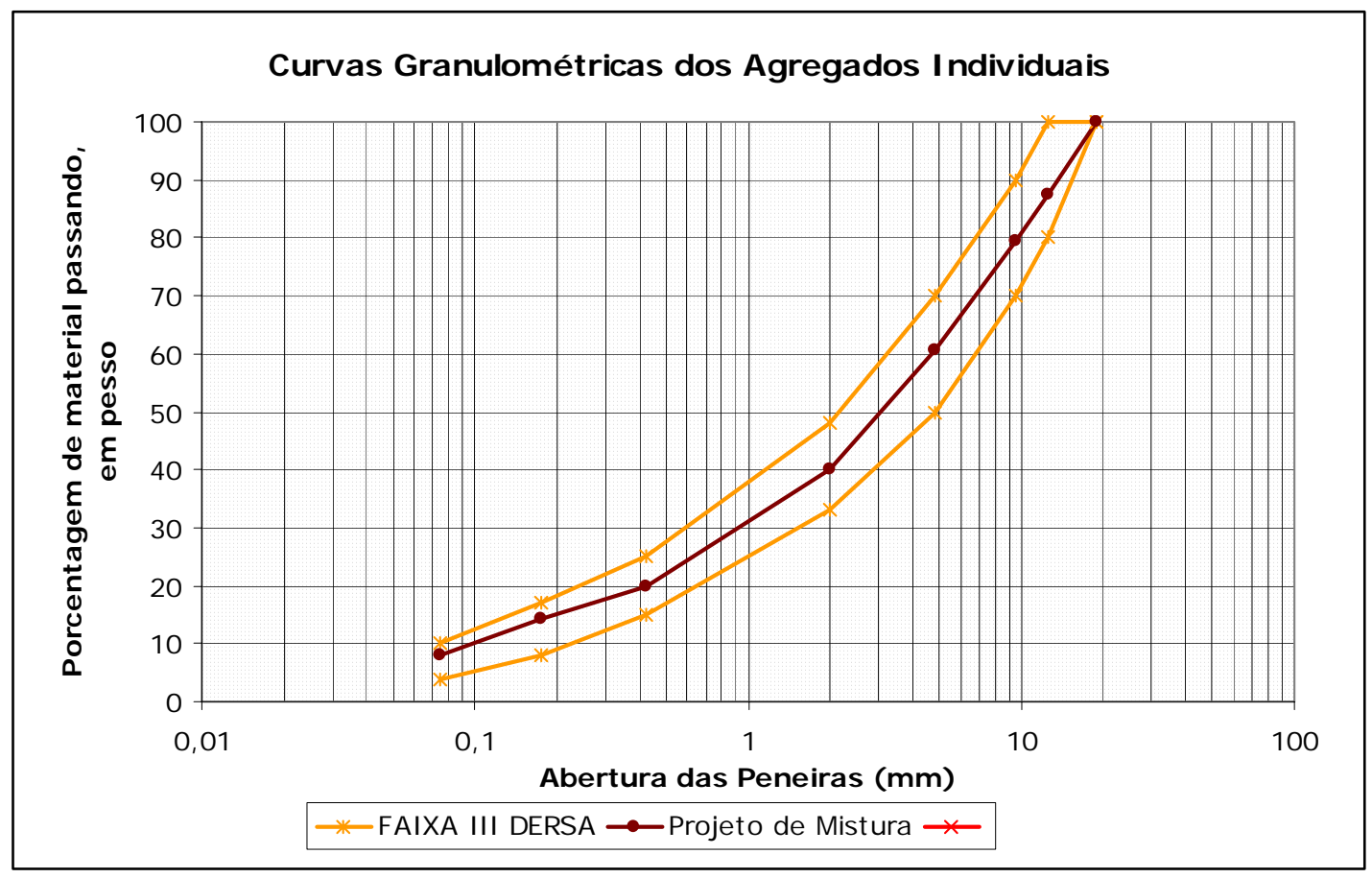

Figura 3.2- Comparativo entre a Curva de Projeto e a faixa III do DERSA

\subsubsection{Ligantes Asfálticos}

Para o desenvolvimento da pesquisa foram considerados oito diferentes tipos de ligantes, dois cimentos asfálticos convencionais, produzidos em escala industrial e seis ligantes modificados por polímero do tipo RET, sendo eles:

- CAP 20 - proveniente de destilação à vácuo, produzido na Refinaria Henrique Lage (REVAP), São José dos Campos;

- CAP $20+1,0 \%$ de Polímero RET $+0,22 \%$ de Catalizador $\mathrm{H}_{3} \mathrm{PO}_{4}$, produzido em laboratório com agitação simples e aquecimento;

- CAP $20+1,5 \%$ de Polímero RET + 0,22\% de Catalizador $\mathrm{H}_{3} \mathrm{PO}_{4}$, produzido em laboratório com agitação simples e aquecimento;

- CAP $20+2,0 \%$ de Polímero RET $+0,22 \%$ de Catalizador $\mathrm{H}_{3} \mathrm{PO}_{4}$, produzido em laboratório com agitação simples e aquecimento;

- CAP 40 - proveniente de destilação à vácuo, produzido na Refinaria Presidente Getúlio Vargas (REPAR), Araucária; 
- CAP $40+1,0 \%$ de Polímero RET + 0,22\% de Catalizador $\mathrm{H}_{3} \mathrm{PO}_{4}$, produzido em laboratório com agitação simples e aquecimento;

- CAP $40+1,5 \%$ de Polímero RET $+0,22 \%$ de Catalizador $\mathrm{H}_{3} \mathrm{PO}_{4}$, produzido em laboratório com agitação simples e aquecimento;

- CAP $40+2,0 \%$ de Polímero RET $+0,22 \%$ de Catalizador $\mathrm{H}_{3} \mathrm{PO}_{4}$, produzido em laboratório com agitação simples e aquecimento;

A Tabela 3.4 a seguir apresenta a especificação do DNIT para os ligantes asfálticos do tipo CAP 20 e CAP 40.

Observa-se que à época de realização dos ensaios laboratoriais e construção do trecho na Rodovia Anhanguera, a classificação dos asfaltos era realizada, na região Sudeste do país, pela viscosidade absoluta. A partir de julho de 2005, a classificação brasileira foi alterada com o emprego do ensaio de Penetração como classificatório, o CAP 20 empregado na pesquisa equivale ao CAP 50/70; o CAP 40, por sua vez, ao CAP 30/45.

Os ensaios de caracterização física foram efetuados no Laboratório da Ipiranga Asfaltos, em Paulínia. 
Tabela 3.4 - Especificações para Cimento Asfáltico de Petróleo - CAP

Classificação por Viscosidade (Portaria DNC 5/ 18.02.93) vigente até julho 2005

\begin{tabular}{|c|c|c|c|c|}
\hline \multirow{2}{*}{ Características } & \multirow{2}{*}{ Unid. } & \multicolumn{3}{|c|}{ Valores } \\
\hline & & CAP-7 & CAP-20 & CAP-40 \\
\hline Viscosidade a $60^{\circ} \mathrm{C}$ & $\mathrm{P}$ & 700 a 1500 & 2000 a 3500 & 4000 a 8000 \\
\hline $\begin{array}{l}\text { Viscosidade Saybolt Furol, } \\
135^{\circ} \mathrm{C} \text {, mín. }\end{array}$ & S & 100 & 120 & 170 \\
\hline Viscosidade Saybolt Furol, $177^{\circ} \mathrm{C}$ & $\mathrm{s}$ & 15 a 60 & 30 a 150 & 40 a 150 \\
\hline Ductilidade a $25^{\circ} \mathrm{C}$, mín. & $\mathrm{cm}$ & 50 & 20 & 10 \\
\hline $\begin{array}{c}\text { Índice de Susceptibilidade } \\
\text { Térmica }\end{array}$ & & $(-1,5)$ a $(+1)$ & $(-1,5)$ a $(+1)$ & $(-1,5)$ a $(+1)$ \\
\hline Penetração $\left(100 \mathrm{~g}, 5 \mathrm{~s}, 25^{\circ} \mathrm{C}\right)$, mín & $0,1 \mathrm{~mm}$ & 90 & 50 & 30 \\
\hline Ponto de Fulgor, mín. & ${ }^{\circ} \mathrm{C}$ & 220 & 235 & 235 \\
\hline $\begin{array}{l}\text { Solubilidade em tricloroetileno, } \\
\text { mín. }\end{array}$ & $\begin{array}{c}\% \\
\text { massa }\end{array}$ & 99,5 & 99,5 & 99,5 \\
\hline Densidade $\left(20 / 4^{\circ} \mathrm{C}\right)$ mínima & & 0,9990 & 0,9990 & 0,9990 \\
\hline \multicolumn{5}{|c|}{ Efeito do Calor e $\mathrm{Ar}, 163^{\circ} \mathrm{C}$ por $5 \mathrm{~h}$} \\
\hline Razão de Viscosidade, máx. & & 4,0 & 4,0 & 4,0 \\
\hline Variação de Massa, máx. & $\%$ & 1,0 & 1,0 & 1,0 \\
\hline
\end{tabular}

\subsubsection{Métodos de Caracterização dos Ligantes}

a) Penetração (DNER ME 003/94)

A consistência do cimento asfáltico (CAP) no estado semi-sólido pode ser avaliada indiretamente pelo ensaio de penetração. Este ensaio consiste em determinar a profundidade, em décimos de milímetro, que uma agulha padronizada (de 100g) penetra verticalmente, durante 5 segundos, em uma amostra de cimento asfáltico à temperatura de $25^{\circ} \mathrm{C}$. Tem-se que o grau de dureza do CAP é tanto maior quanto menor for o valor da penetração da agulha na amostra. 
Este ensaio isoladamente não caracteriza de forma apropriada a qualidade de um cimento asfáltico, contudo, dá uma indicação do seu grau de dureza, sendo utilizado em algumas especificações como parâmetro de classificação e também para avaliar indiretamente o envelhecimento do material betuminoso recuperado de um revestimento existente.

b) Ponto de Amolecimento (DNER ME 247/94)

Os asfaltos amolecem quando submetidos ao aquecimento e não possuem ponto de fusão bem definido. Com a finalidade de se ter uma referência semelhante ao ponto de fusão, vários métodos foram desenvolvidos para medir a temperatura na qual o asfalto possui determinada consistência. O Ponto de Amolecimento Anel e Bola, mundialmente conhecido, determina a temperatura na qual o asfalto amolece quando aquecido em condições padronizadas.

Nesse ensaio o ponto de amolecimento é a mais baixa temperatura na qual uma esfera metálica padronizada atravessa um anel também padronizado preenchido com o material betuminoso e percorre determinada distância, sob condições especificadas.

Ressalta-se que essa é uma medida empírica de consistência dos materiais betuminosos e corresponde, aproximadamente, à temperatura do ponto de fusão.

c) Ductilidade (DNER ME 167/94)

É a distância em centímetros que uma amostra de material betuminoso se rompe, em condições padronizadas, quando submetida a uma tração. A temperatura do ensaio é de $25^{\circ} \mathrm{C}$, podendo ser realizado em outras temperaturas, e a velocidade de deformação de $5 \mathrm{~cm} / \mathrm{min}$.

Essa propriedade caracteriza a capacidade de um material suportar grandes deformações (alongamentos) sem ruptura, representando a resistência à tração e a flexibilidade do CAP. Quanto mais dúctil, maior a flexibilidade do material. O ensaio consiste em moldar um corpo de prova e colocá-lo no aparelho denominado 
Ductilômetro que submete a amostra um alongamento horizontal até ser atingida a ruptura. O deslocamento, em centímetros, por ocasião da ruptura da amostra, é a medida da ductilidade.

A maioria dos CAPs para pavimentação têm ductilidade superior a $60 \mathrm{~cm}$. Deve-se observar que o valor exato da ductilidade não é tão importante como o fato do material betuminoso ter que ser dúctil, ou seja, um CAP com ductilidade $60 \mathrm{~cm}$ pode ser tão bom quanto um outro de ductilidade $150 \mathrm{~cm}$. Muitos pesquisadores são contrários as especificações indicarem "maior do que $100 \mathrm{~cm}$ " para alguns tipos de CAP e "maior do que $60 \mathrm{~cm}$ " para outros tipos. Evidentemente, um valor de ductilidade menor que $10 \mathrm{~cm}$ está associado a um ligante oxidado por um aquecimento muito elevado ou a um envelhecimento em serviço do revestimento antigo.

O importante é que a ductilidade muito baixa caracteriza uma grande fragilidade do material, enquanto que valores muito elevados podem até indicar maiores suscetibilidades à temperatura.

\section{d) Ponto de Fulgor (DNER ME 148/94)}

O ponto de fulgor é a menor temperatura na qual os vapores emanados durante o aquecimento do material betuminoso se inflamam quando sobre ele passa uma chama sob determinadas condições. Esse ensaio tem por finalidade evitar acidentes de trabalho e verificar possível contaminação do cimento asfáltico com asfalto diluído.

Alguns estudiosos acham que os CAP com elevado ponto de fulgor têm elevada durabilidade, embora não esteja ainda perfeitamente comprovado. De maneira geral os CAP's têm Ponto de Fulgor normalmente superior a $230^{\circ} \mathrm{C}$. Portanto, a sua contaminação com o asfalto diluído diminui sensivelmente a temperatura de inflamação do CAP e reflete-se também, na aptidão à compactação da mistura betuminosa. 
e) Retorno Elástico (DNER ME 382/99)

A recuperação elástica é a medida da capacidade de retorno do sistema asfaltopolímero após interrupção do esforço de tração mecânica especificado. A amostra é colocada em um molde, preparada, introduzida em um banho d'água e submetida a uma tração que produza um alongamento de 200mm (através do ductilômetro), quando o material é secionado, é verificado o seu retorno ou recuperação elástica após $60 \mathrm{~min}$ de repouso. Efetua-se o ensaio à temperatura de $25 \pm 0,5^{\circ} \mathrm{C}$ e à velocidade de $5 \pm 0,25 \mathrm{~cm} / \mathrm{min}$.

f) Compatibilidade ou Separação de Fases (DNER ME 384/99)

Um forma prática de ser verificar a compatibilidade de uma mistura asfalto/polímero é pela colocação de uma amostra em tubo cilíndrico de alumínio com uma das extremidades fechada, o qual é mantido na mesma posição vertical, à temperatura de cerca de $163^{\circ} \mathrm{C}$. Após cinco dias o tubo é retirado da estufa, resfriado e a análise do ponto de amolecimento é efetuada nas amostras do topo e do fundo do tubo. Quanto menor for a diferença entre estes resultados melhor é a compatibilidade entre o polímero e o asfalto.

Segundo a especificação brasileira para asfaltos modificados por polímeros DNER EM 396/99 a diferença entre o Ponto de Amolecimento da amostra coletada no topo e no fundo não deve ser superior a $4^{\circ} \mathrm{C}$.

g) Viscosidade Brookfield (NBR 15184)

É utilizado para avaliar a viscosidade aparente do asfalto nas temperaturas de transporte, usinagem e compactação de forma a assegurar adequada trabalhabilidade. 
h) Densidade a 20/4 C (DNER ME 193/96)

A densidade a $20 / 4^{\circ} \mathrm{C}$ é a relação entre a massa do CAP a $20^{\circ} \mathrm{C}$ e a massa de igual volume de água a $4^{\circ} \mathrm{C}$, caracterizando a natureza do material. Esse ensaio tem por finalidade a transformação de unidades gravimétricas em volumétricas e é utilizada no cálculo do volume de vazios de misturas asfálticas.

Considerando a massa específica da água igual a $1,0 \mathrm{~g} / \mathrm{cm}^{3}$ a $4^{\circ} \mathrm{C}$, o número representativo da densidade do CAP é, portanto, adimensional. No procedimento para sua determinação são utilizados os chamados picnômetros de Hubbard e balanças analíticas de grande sensibilidade.

i) Efeito do Calor e Ar (ABNT MB-425)

Os resultados obtidos neste teste permitem avaliar a presença de frações de óleos mais leves e/ou a oxidação que ocorre durante o aquecimento de uma amostra de $50 \mathrm{~g}$ a $163^{\circ} \mathrm{C}$ durante 5 horas. Tenta-se, assim, simular as condições de usinagem de asfalto. Após este período, é medida a variação de massa que o material betuminoso sofreu.

Ressalta-se que após este procedimento é também usual submeter o material resultante aos ensaios de Penetração, Ponto de Amolecimento, Ductilidade e Recuperação Elástica, condicionando-se os resultados a novas exigências de aceitação. A metodologia para esses ensaios é a mesma citada anteriormente.

j) Índice de Susceptibilidade Térmica

Estudos de laboratório têm mostrado que, quando a temperatura (t) aumenta, o asfalto amolece e conseqüentemente a penetração $(\mathrm{P})$ aumenta. A curva do gráfico abaixo caracteriza a sensibilidade do CAP às variações da temperatura. 


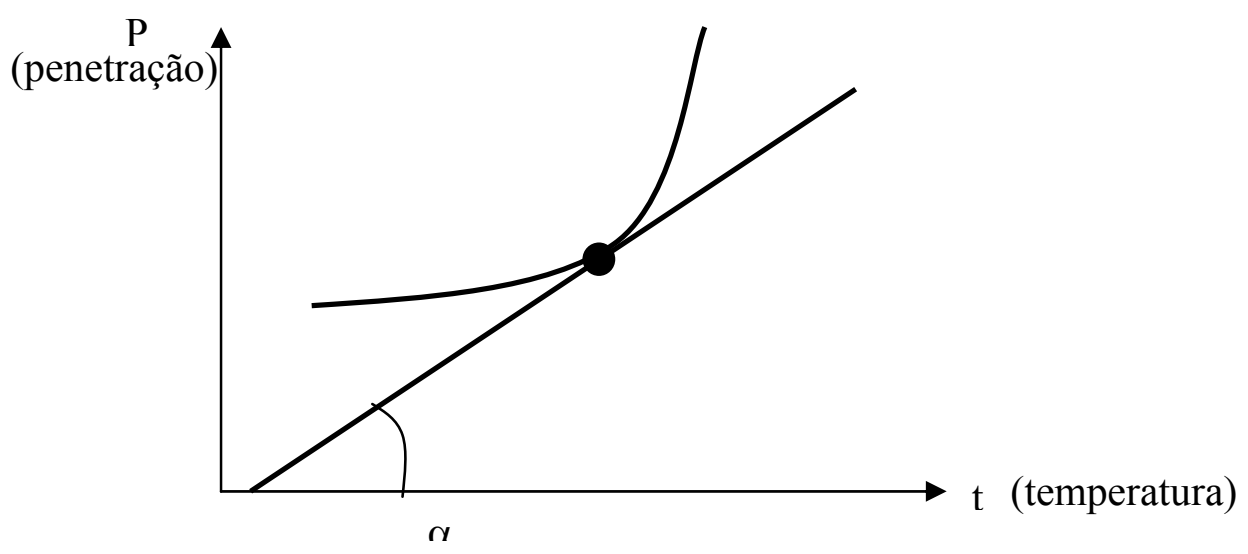

Figura 3.3- Sensibilidade do CAP às variações da temperatura

$$
\operatorname{tg} \alpha=\frac{d P}{d t}
$$

Esses estudos têm também evidenciado que a variação da penetração com a temperatura em um sistema $\log (\mathrm{P})$ versus t é uma linha reta cujo coeficiente angular traduz a suscetibilidade térmica do CAP.

Tendo em vista que a penetração é muito próxima a $800(0,1 \mathrm{~mm})$ na temperatura do ponto de amolecimento (PA), é possível, portanto, definir a suscetibilidade térmica em termos de penetração a partir do gráfico abaixo:

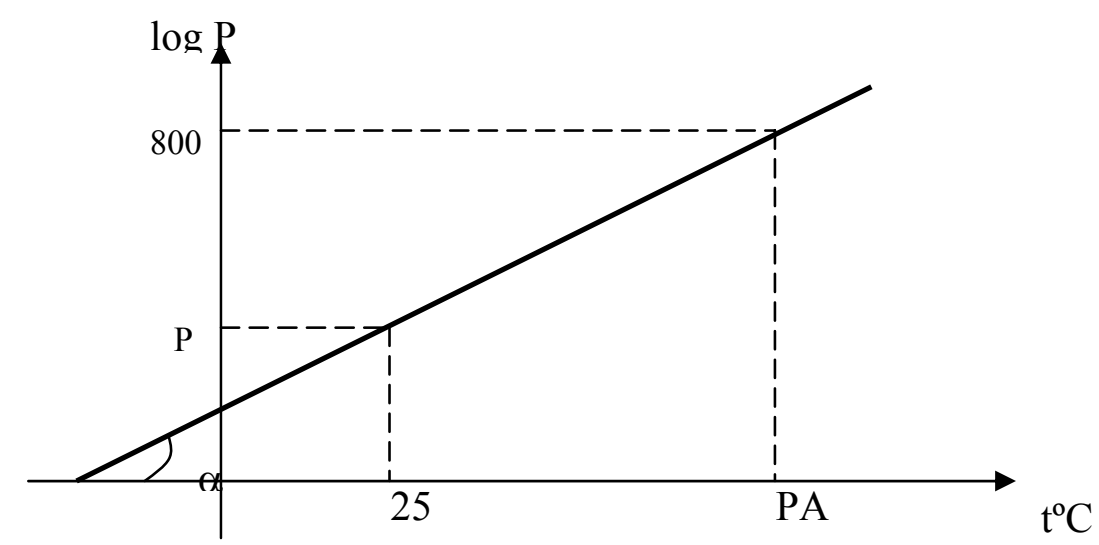

Figura 3.4- Suscetibilidade Térmica em termos de penetração

$$
\operatorname{tg} \alpha=\frac{\log 800-\log P}{P A-25}
$$


Pfeiffer e Van Doormaal definiram uma equação onde a suscetibilidade térmica tem um valor próximo a zero para os asfaltos usados em pavimentação, introduzindo o chamado Índice de Penetração (IP) sob a forma:

$$
\frac{d \log P}{d t}=0,02 \frac{20-I S T}{10+I S T}
$$

Confrontando as duas expressões apresentadas anteriormente, tem-se:

$$
I S T=\frac{500 \log P+20 P A-1951}{120-50 \log P+P A}
$$

O IST é o índice de suscetibilidade térmica de Pfeiffer e Vann Doormaal que nas especificações brasileiras para asfaltos convencionais pode variar de $(-1,5)$ a $(+1)$ até julho de 2005, e que a partir desta data está limitado entre $(-1,5)$ a $(+0,7)$. Valores superiores a $(+1)$ indicam, em geral, asfaltos oxidados, ou seja, pouco sensíveis a elevadas temperaturas e quebradiços, ou frágeis, quando a temperatura é baixa; já os valores inferiores a (-2) indicam, em geral, asfaltos muito sensíveis a altas temperaturas, ou seja, que amolecem rapidamente.

\subsubsection{Misturas Asfálticas}

\subsubsection{Misturas Empregadas}

Para elaboração do estudo foram escolhidas as taxas de polímero RET consideradas mais apropriadas para a modificação dos cimentos asfálticos convencionais dos tipos CAP 20 e CAP 40. Na seqüência, para a determinação do teor ótimo de ligante, foram elaborados projetos de mistura na Faixa III do DERSA através da metodologia Marshall (DNER ME 043/95), com os seguintes asfaltos:

- CAP $20+1,5 \%$ de Polímero RET + 0,22\% de Catalizador $\mathrm{H}_{3} \mathrm{PO}_{4}$, produzido em laboratório com agitação simples e aquecimento;

- CAP $40+1,0 \%$ de Polímero RET + 0,22\% de Catalizador $\mathrm{H}_{3} \mathrm{PO}_{4}$, produzido em laboratório com agitação simples e aquecimento; 
Após a elaboração dos projetos de mistura com os asfaltos modificados foram moldados, para cada um dos asfaltos convencionais (CAP 20 e CAP 40), oito corpos de prova e realizada a verificação do teor ótimo da mistura para a utilização dos ligantes convencionais.

Os corpos de prova foram moldados segundo a metodologia Marshall com 75 golpes em cada face, em diferentes teores de ligantes. Buscou-se obter corpos-de-prova com as mesmas características de homogeneidade obtida na usina, ou seja, as diversas frações (brita 0 , brita 1 e pó de pedra) eram quarteadas e em seguida misturadas de forma a se obter uma granulometria uniforme para todos corpos-de-prova.

\subsubsection{Métodos de Caracterização das Misturas}

a) Moldagem com Compactador Marshall

Foram moldados corpos-de-prova (cps) no compactador Marshall para realização de ensaios de módulo de resiliência e resistência à tração. Preparou-se um traço da mistura com aproximadamente $1.200 \mathrm{~g}$ de material para confecção de cada corpo-deprova. O ensaio consiste em aquecer o ligante e os agregados nas temperaturas prédefinidas em função da curva de viscosidade do ligante.

Misturou-se o ligante aos agregados e fíler durante dois a três minutos na temperatura de usinagem e, em seguida, preencheu-se o molde para compactação com 75 golpes em cada uma das faces do corpo-de-prova. Após a mistura dos materiais, o recipiente com a mistura permaneceu em estufa, na temperatura de compactação, pelo período de duas horas para simular o efeito do condicionamento de curto prazo equivalente ao período de usinagem e transporte entre a usina e a pista. Em seguida, a amostra foi levada à compactação.

b) Densidade Aparente (DNER-ME 117/94)

Após o desmolde do corpo-de-prova cilíndrico são efetuadas quatro medidas de altura e diâmetro para obter um valor médio das dimensões dos corpos de prova. 
A densidade aparente foi estimada, pesando-se os corpos-de-prova primeiramente secos e depois submersos, e empregando o peso específico da água.

c) Densidade Máxima Medida (ASTM D 2041/00 - Método Rice)

Este método permite determinar a massa específica máxima medida e a densidade da mistura asfáltica não compactada a $25^{\circ} \mathrm{C}(\mathrm{Gmm})$. A massa específica máxima é usada no cálculo dos vazios com ar na mistura asfáltica compactada, no cálculo da quantidade de ligante absorvido pelo agregado, além de fornecer valores de projeto para compactação das misturas asfálticas. O ensaio consiste em colocar uma amostra de mistura asfáltica, em condição solta em um recipiente com água $\left(25^{\circ} \mathrm{C}\right)$ até submersão total da amostra. Em seguida aplica-se gradualmente vácuo para reduzir a pressão residual dentro do recipiente para $30 \mathrm{mmHg}$ ou menos que será mantido por dois minutos sob agitação mecânica. Ao fim deste período de tempo, o vácuo é gradualmente eliminado. $\mathrm{O}$ volume da amostra da mistura é obtido complementando o nível do recipiente com água e pesando-se ao ar. A massa e a temperatura são anotadas. A partir das medidas de massa, calcula-se a massa específica ou densidade real da mistura corrigindo-a para a temperatura de $25^{\circ} \mathrm{C}$.

d) Resistência à Tração Indireta Estática (DNER-ME 138/94)

O ensaio de compressão diametral ou tração indireta, conhecido internacionalmente como "ensaio brasileiro", foi desenvolvido pelo Professor Fernando Luiz Lobo Carneiro para determinar a resistência à tração de corpos de prova de concreto através de carregamento estático. O corpo de prova cilíndrico é posicionado diametralmente em relação à direção da compressão, resultando numa tração, agindo perpendicularmente ao longo do plano diametral que promove a ruptura do corpo nesta direção. É realizado numa prensa Marshall, sendo o corpo de prova apoiado ao longo de suas geratrizes por dois frisos de carga posicionados na parte superior e inferior do corpo-de-prova, devidamente padronizados. 
e) Módulo de Resiliência por Compressão Diametral (DNER-ME 133/94)

O Módulo de Resiliência é definido como sendo a relação da tensão de tração gerada no corpo de prova com a deformação de tração recuperável correspondente. Este ensaio consiste em solicitar o corpo-de-prova por uma carga repetida de compressão diametral distribuída ao longo de duas geratrizes opostas e medir a deformação resiliente ao longo do diâmetro horizontal, perpendicular à carga aplicada. A duração da carga de compressão usual é de 0,1 segundos, com repouso de 0,9 segundos.

f) Ensaio de Deformação Permanente no Simulador de Tráfego Tipo LPC Laboratoire Central des Ponts et Chaussées

O ensaio de deformação permanente é realizado para verificar a resistência da mistura estudada à ação do tráfego em relação à deformação da trilha de roda. Este ensaio é composto por três partes distintas, sendo estas descritas a seguir.

\section{ఐ Misturação}

O processo de usinagem da mistura asfáltica segue este procedimento: pesagem do material já pré-aquecido em estufa na quantidade exata do traço; quando os agregados atingem a temperatura de usinagem, são colocados dentro do tacho da misturadora, (tacho já aquecido previamente) e, após a homogeneização dessas partes, adiciona-se o ligante asfáltico na temperatura de usinagem, conforme o projeto descrito anteriormente.

Misturam-se esses materiais até homogeneização visual. Todo esse processo decorre no período de 5 a 8 minutos. A Figura 3.5 abaixo mostra a misturadora desenvolvida para esta finalidade. 


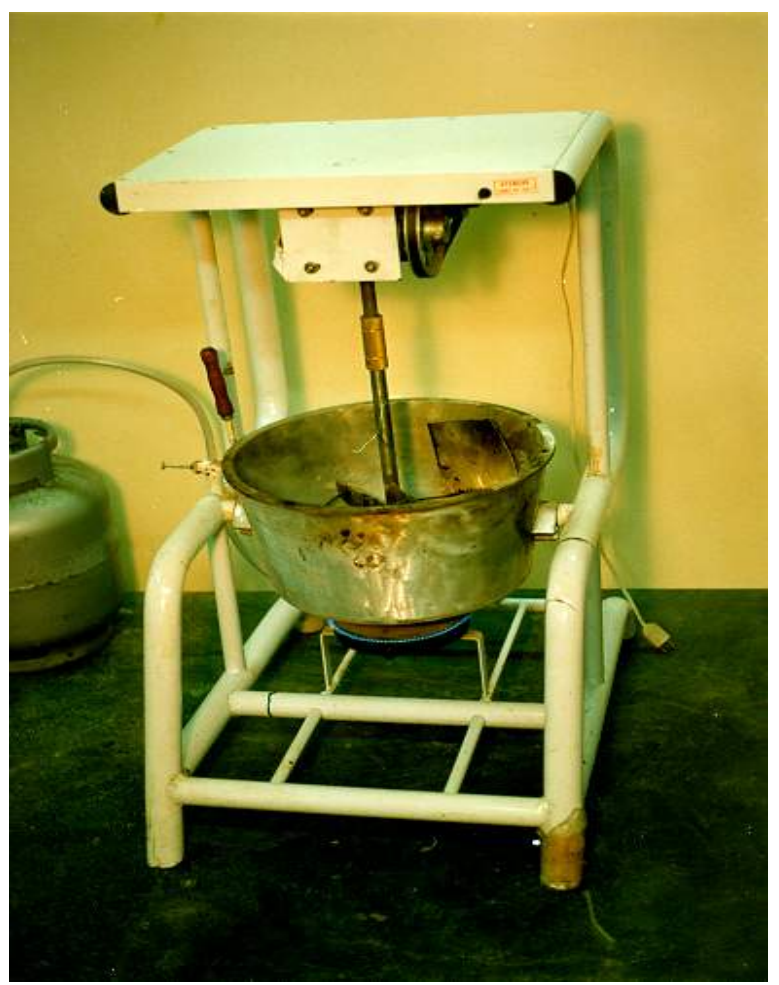

Figura 3.5 - Misturadora

Transfere-se a mistura asfáltica do tacho da misturadora para uma bandeja, mede-se a temperatura que a mistura apresenta imediatamente após a usinagem, em seguida é colocada dentro de uma estufa regulada com temperatura para moldagem (temperatura correspondente à compactação).

\section{$\square$ Compactação das Placas}

As placas de misturas asfálticas do tipo CBUQ foram compactadas por amassamento, simulando a compactação de campo, por meio de um equipamento denominado "mesa compactadora tipo LCPC francês (Laboratoire Central des Ponts et Chaussées) - Foto 3.6, conforme especificação francesa NF P 98-250-2 Preparation dês Mélanges Hydrocarbonés. As placas possuem as dimensões de $500 \mathrm{~mm}$ de comprimento x $180 \mathrm{~mm}$ de largura por $50 \mathrm{~mm}$ de espessura. 


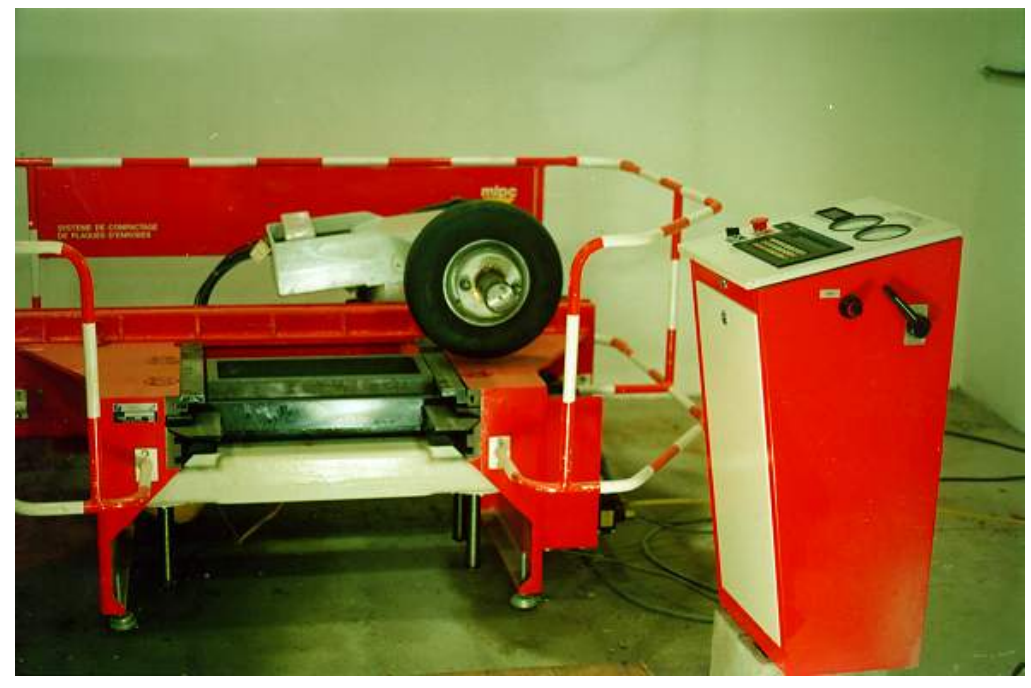

Figura 3.6 - Mesa Compactadora tipo LCPC

Foram usinadas quantidades exatas de misturas asfálticas segundo o projeto Marshall, e quando compactadas ocuparam todo o volume do molde, obtendo assim a densidade desejada. As temperaturas de compactação são as apresentadas no projeto.

\section{$\square$ Deformação Permanente nas Trilhas de Roda}

Os ensaios de Deformação Permanente nas trilhas de roda foram realizados em simulador de tráfego tipo LPC francês (Laboratoire des Ponts et Chaussées). A Figura 3.7 mostra sendo testadas duas placas de cada vez. Os ensaios foram realizados conforme especificação francesa NF P 98-253-1 Déformation Permanente des Mélanges Hydrocarbonés.

Os ensaios de deformação permanente em trilhas de roda foram conduzidos a $60^{\circ} \mathrm{C}$, até 30.000 ciclos, como especificado na norma francesa anteriormente mencionada. Foram realizadas medidas intermediárias de afundamentos em trilha de roda, conforme preconizado na norma. As medidas de afundamentos na superfície são realizadas em cinco diferentes seções transversais da placa, com três leituras ao longo de cada seção, totalizando quinze pontos medidos em cada etapa de ciclos. $\mathrm{O}$ afundamento medido em cada determinado número de ciclos refere-se à média destes quinze pontos medidos, referenciados à primeira leitura. 


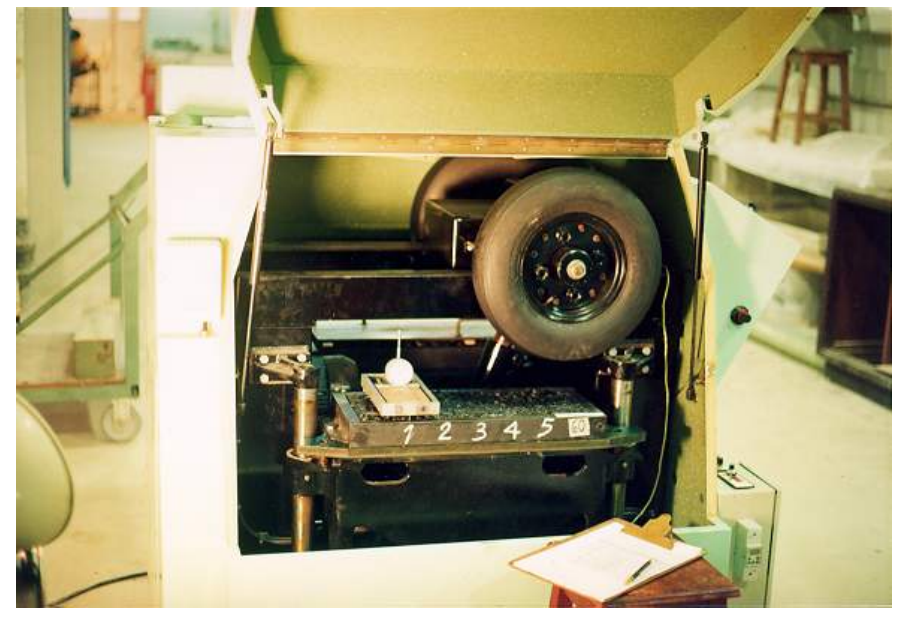

Figura 3.7 - Simulador LPC

\subsection{Trecho Experimental da Rodovia Anhenguera}

\subsubsection{Agregados}

\subsubsection{Origem}

No trecho experimental executado foram empregados agregados de natureza mineral granítica, proveniente da Pedreira Basalto 6, localizada na Estrada Velha de Indaiatuba em Campinas, estado de São Paulo. Este material foi escolhido por ser um agregado de boas características físicas e mecânicas e próximo ao segmento restaurado.

\subsubsection{Análise Granulométrica}

Para composição da curva granulométrica do projeto foram selecionadas quatro frações: brita $1(19 \mathrm{~mm})$, pedrisco $(12,5 \mathrm{~mm})$, pó de pedra $(4,8 \mathrm{~mm})$ e fíler (Cal CH1). As características granulométricas dos agregados graúdos e miúdos são apresentadas na Tabela 3.5 e na Figura 3.8. 
Tabela 3.5 - Análise Granulométrica dos Agregados

\begin{tabular}{|c|c|c|c|c|c|}
\hline \multicolumn{2}{|c|}{ PENEIRA } & BRITA 1 & PEDRISCO & PO DE PEDRA & CAL CH I \\
\hline Abertura (mm) & Poleg./N & \multicolumn{4}{|c|}{ (\% que passa) } \\
\hline 19,0 & $3 / 4$ & 100,0 & - & - & - \\
12,5 & $1 / 2$ & 44,0 & 100,0 & - & - \\
9,52 & $3 / 8$ & 16,0 & 99,0 & 100,0 & - \\
4,80 & 4 & 1,0 & 13,0 & 98,0 & - \\
2,00 & 10 & 0,5 & 2,0 & 63,0 & - \\
0,42 & 40 & 0,1 & 1,5 & 27,0 & 100,0 \\
0,175 & 80 & - & 1,0 & 18,0 & 98,0 \\
0,075 & 200 & - & 0,5 & 10,0 & 95,0 \\
\hline
\end{tabular}

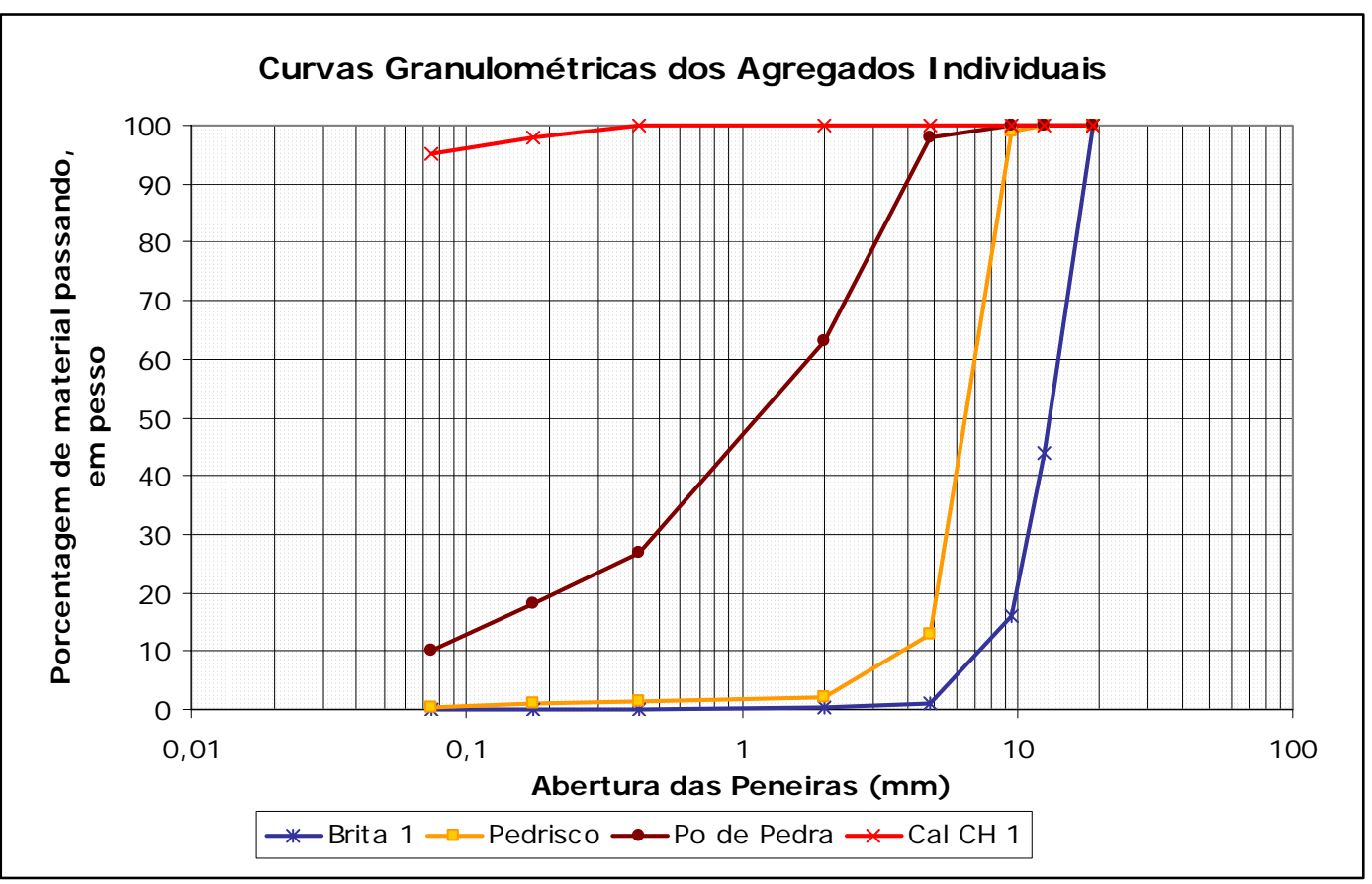

Figura 3.8 - Curvas Granulométricas dos Agregados Empregados 


\subsubsection{Características dos Agregados}

Durante a elaboração do projeto de mistura foram executados ensaios de caracterização do material pétreo pelo Consórcio Construban, responsável pela qualidade dos serviços executados no sistema administrado pela Empresa Autoban.

Os ensaios realizados seguiram as metodologias e ensaios apresentados a seguir.

a) Granulometria (DNER 083/94)

e) Abrasão Los Angeles (DNER ME 035/94)

f) Equivalente Areia (DNER ME 054/94)

g) Durabilidade Frente ai Sulfato de Sódio (DNER ME 089/94)

i) Índice de Forma (DNER ME 086/94)

j) Índice de Plasticidade (DNER ME 082/94)

h) Limite de Liquidez (DNER ME 122/94)

A Tabela 3.6 apresenta as características do agregado estudado.

Tabela 3.6: Características do Agregado Estudado

\begin{tabular}{|c|c|c|c|}
\hline Ensaio & Método & Obtido & Especificado \\
\hline Abrasão Los Angeles & DNER ME 035/94 & $16 \%$ & $<50 \%$ \\
\hline Equivalente de Areia (sem cal) & DNER ME 054/94 & $79,9 \%$ & $>55 \%$ \\
\hline $\begin{array}{l}\text { Durabilidade Frente ao Sulfato de } \\
\text { Sódio (Brita } 1 \text { e Pedrisco) }\end{array}$ & DNER ME 089/94 & $0,10 \%$ & $<15 \%$ \\
\hline $\begin{array}{l}\text { Durabilidade Frente ao Sulfato de } \\
\text { Sódio (Pó de Pedra) }\end{array}$ & DNER ME 089/94 & $0,40 \%$ & $<18 \%$ \\
\hline Índice de Forma (Brita 1) & DNER ME 086/94 & $0,79 \%$ & $>0,5 \%$ \\
\hline Índice de Plasticidade & DNER ME 082/94 & NP & $<6,0 \%$ \\
\hline Limite de Liquidez & DNER ME 122/94 & NP & $<25 \%$ \\
\hline
\end{tabular}




\subsubsection{Escolha da Curva Granulométrica}

A curva utilizada foi escolhida pelo Consórcio Construban, que optou pela utilização da Faixa III do DERSA. Esta faixa tem sido utilizada ao longo dos últimos anos nas restaurações das rodovias Anhanguera e Bandeirantes. São apresentados na Tabela 3.7 e na Figura 3.9 os percentuais dos agregados e a curva granulométrica de projeto.

Tabela 3.7 - Distribuição percentual dos agregados e curva de projeto

\begin{tabular}{|c|c|c|c|c|c|c|c|}
\hline \multicolumn{2}{|c|}{ PENEIRA } & \multirow{2}{*}{ BRITA 1} & \multirow{2}{*}{ PEDRISCO } & \multirow{2}{*}{$\begin{array}{l}\text { PO DE } \\
\text { PEDRA }\end{array}$} & \multirow{2}{*}{ CAL CH1 } & \multirow{4}{*}{$\begin{array}{c}\text { GRANUL. } \\
\text { OBTIDA } \\
(\%)\end{array}$} & \multirow{4}{*}{$\begin{array}{l}\text { Especificaçã } \\
\text { o DERSA } \\
\text { ET- } \\
\text { P00/027FIII }\end{array}$} \\
\hline \multirow{3}{*}{$\begin{array}{c}\text { Abertura } \\
\mathrm{mm}\end{array}$} & \multirow{3}{*}{$\begin{array}{l}\text { Poleg. } \\
\text { /N }\end{array}$} & & & & & & \\
\hline & & $20,0 \%$ & $17,5 \%$ & $61,0 \%$ & $1,5 \% \%$ & & \\
\hline & & \multicolumn{4}{|c|}{ (\% que passa) } & & \\
\hline 19,0 & $3 / 4$ & 100,0 & - & - & - & 100,0 & 100 \\
\hline 12,5 & $1 / 2$ & 44,0 & 100,0 & - & - & 88,8 & $80-100$ \\
\hline 9,52 & $3 / 8$ & 16,0 & 99,0 & 100,0 & - & 83,0 & $70-90$ \\
\hline 4,80 & 4 & 1,0 & 13,0 & 98,0 & - & 63,8 & $50-70$ \\
\hline 2,00 & 10 & 0,5 & 2,0 & 63,0 & - & 40,4 & $33-48$ \\
\hline 0,42 & 40 & 0,1 & 1,5 & 27,0 & 100,0 & 18,3 & $15-25$ \\
\hline 0,175 & 80 & - & 1,0 & 18,0 & 98,0 & 12,6 & $8-17$ \\
\hline 0,075 & 200 & - & 0,5 & 10,0 & 95,0 & 7,6 & $4-10$ \\
\hline
\end{tabular}




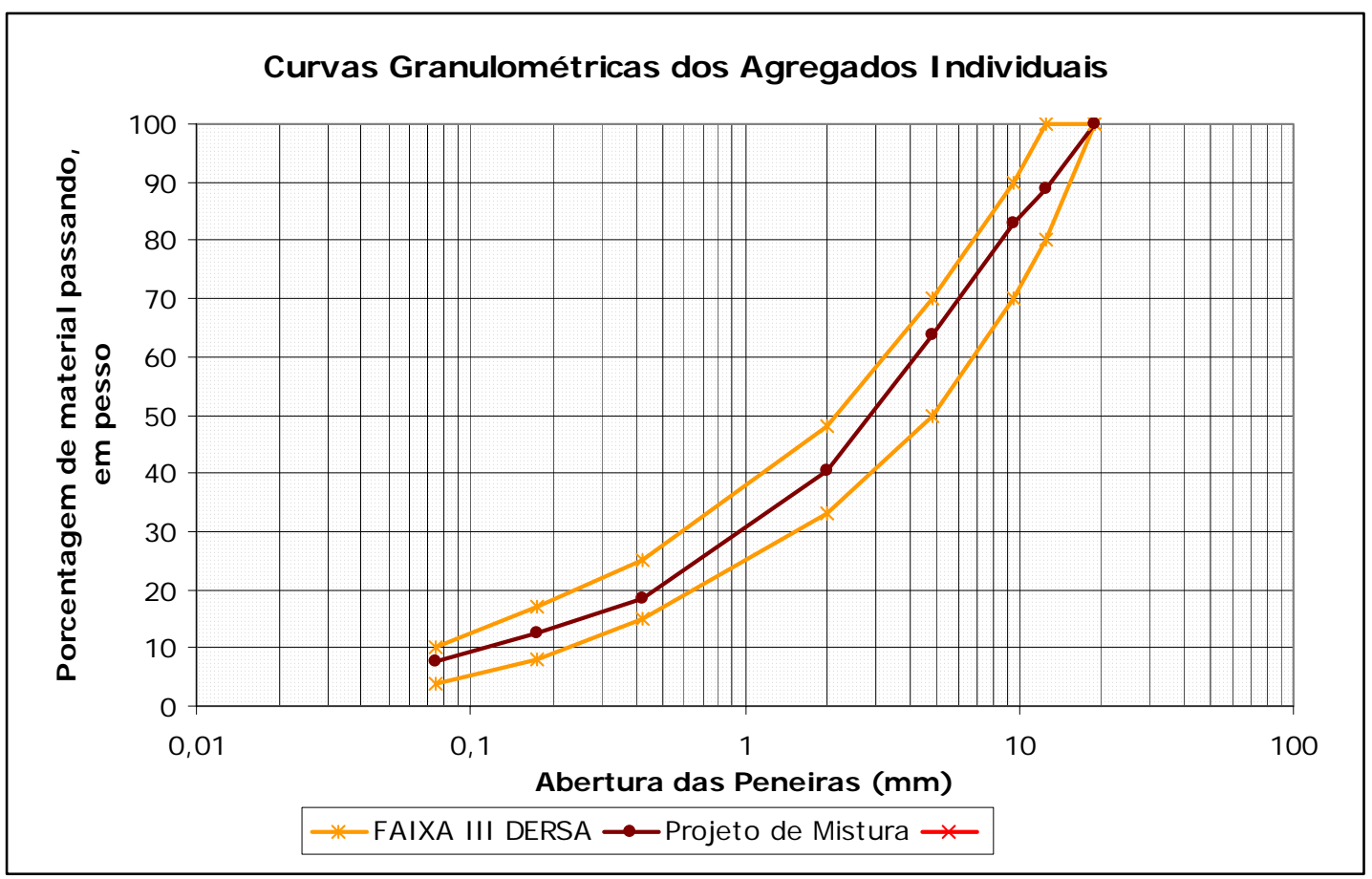

Figura 3.9- Comparativo entre a Curva de Projeto, EME 0/14 e faixa B do DNER.

\subsubsection{Ligantes Asfálticos}

Na restauração do Trecho Experimental foram utilizados dois tipos de ligantes, um cimento modificado por polímero do tipo RET e um asfalto convencional, utilizado como trecho de referência para comparar o desempenho das duas misturas:

- CAP 40 - proveniente de destilação à vácuo, produzido na Refinaria Presidente Getúlio Vargas (REPAR), Araucária;

- CAP $40+1,5 \%$ de Polímero RET $+0,22 \%$ de Catalizador $\mathrm{H}_{3} \mathrm{PO}_{4}$, produzido na Usina de Asfalto instalada na pedreira Basalto 6, por agitação simples e aquecimento. 
A modificação do asfalto com $1,5 \%$ de polímero RET e $0,22 \%$ de Catalizador $\mathrm{H}_{3} \mathrm{PO}_{4}$ foi realizada em um dos tanques de armazenamento de ligante da Usina utilizada na fabricação da mistura asfáltica. O tanque utilizado na modificação foi adaptado com a colocação de dois funis para a adição do polímero e dois conjuntos de agitadores, cada um composto por um eixo maciço com diâmetro de 3 polegadas, dois conjuntos de hélice com três paletas cada e um conjunto moto redutor com potência de $15 \mathrm{Cv}$ e rotação final de 115RPM - Figura 3.10.

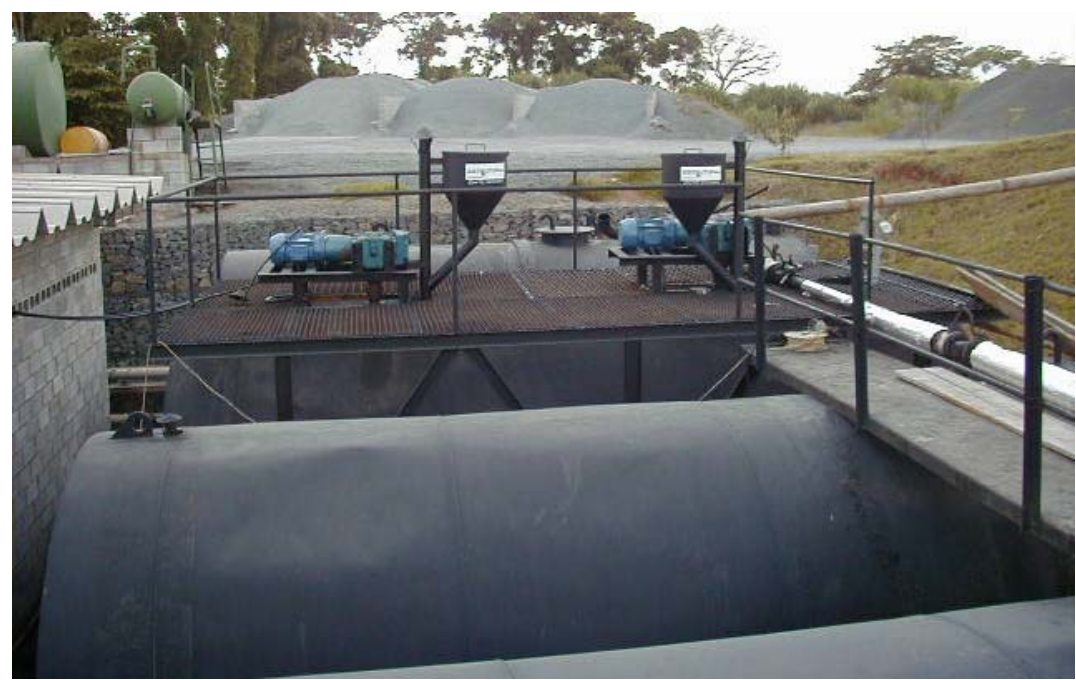

Figura 3.10 - Tanque Adaptado para Modificação de Asfalto

\subsubsection{Monitoramento do Trecho Experimental}

Com o objetivo de se possibilitar a análise objetiva do desempenho do revestimento executado, realizou-se o monitoramento periódico das condições estruturais, superficiais, funcionais e de segurança do pavimento, através da realização de ensaios não destrutivos in situ, conforme detalhado a seguir.

- Deflectometria: medidas de deflexões recuperáveis com o Falling Weight Deflectometer (FWD), de forma periódica, para verificação da evolução da condição da estrutura face à solicitação de cargas; 
- Irregularidade: medidas periódicas do Quociente de Irregularidade (QI), com equipamento tipo resposta, para verificação da condição de conforto ao rolamento no referido trecho;

- Inventário de Superfície: Levantamento Visual Detalhado (LVD) para o cadastro com a localização, dimensão e descrição dos defeitos existentes;

- Aderência: avaliação do coeficiente de atrito com medidas pontuais em unidades de amostragem aleatórias, empregando-se o "Pêndulo Britânico" e ensaios de mancha de areia, para a verificação das condições de segurança dos usuários caracterizando-se a microtextura e a macrotextura da superfície após três anos da execução do segmento.

\subsubsection{Deflectometria}

Desde a percepção de que o problema de capacidade de carga de pavimentos deve-se também a deformabilidade elástica das camadas, a determinação desta característica por ensaios não-destrutivos vem desempenhando papel preponderante na busca da racionalização da análise e projeto dessas estruturas.

Entre os ensaios não-destrutivos (NDT) estão incluídos os deflectométricos que consistem em medições dos deslocamentos verticais recuperáveis na superfície do pavimento quando submetido à aplicação de cargas transientes auxiliando, quando adequadamente interpretados, na avaliação da capacidade das camadas do pavimento em resistir os efeitos decorrentes das cargas de tráfego (SCULLION, 1999).

i.

Os deflectômetros do impacto do tipo Falling Weight Deflectomenter (FWD), incorporados ao meio rodoviário no início da década de 80 , tem utilização crescente no mundo. Representam uma nova fase de ensaios não destrutivos para avaliação estrutural de pavimentos asfálticos e de concreto, de pistas de aeroportos e de 
rodovias, pois representa uma evolução dos procedimentos de prova de carga quase estáticos (viga Benkelman) para ensaios dinâmicos através de impacto que procuram simular um pulso de carga semelhante à passagem de veículo com velocidade entre 60 e $80 \mathrm{~km} / \mathrm{h}$ num ponto na superfície do pavimento (MACÊDO, 1996).

No Brasil conta-se com este equipamento desde 1988, sendo que no ano 2000 existiam no País nove equipamentos tipo FWD; sendo sete de fabricação Dynatest, versão norte-americana, e dois do tipo KUAB, versão Sueca.

O equipamento utilizado para a determinação das deflexões recuperáveis foi o FWD Dynatest Modelo 8000E, que é um deflectômetro de impacto desenvolvido na Dinamarca e aperfeiçoado nos EUA.

O FWD Dynatest é montado num trailer que pode ser rebocado por qualquer veículo devidamente equipado, de capacidade média de carga. O pulso de carga transiente é gerado pela queda de um conjunto de massas metálicas sobre um sistema de colchões amortecedores de borracha, que transmite a carga ao pavimento através de uma placa apoiada sobre uma membrana de borracha. A operação de elevação e queda do conjunto de massas sobre os amortecedores de borracha é controlada por um sistema eletro-hidráulico (PITTA, 1998).

Acompanha o aparelho uma placa com $300 \mathrm{~mm}$ de diâmetro, que foi empregada para permitir uma área de contato semelhante à do eixo padrão rodoviário brasileiro, e outra de $450 \mathrm{~mm}$. Ambas podem inclinar-se em até seis graus em relação a horizontal para facilitar o ajuste à superfície do pavimento.

A força aplicada ao pavimento pode variar entre 7 a $111 \mathrm{kN}$ pela modificação da altura de queda e/ou pela alteração da configuração do conjunto de massas utilizado. $\mathrm{Na}$ placa circular existe uma célula de carga que mede a carga do impacto proveniente da queda do conjunto de massas.

Nos estudos em questão empregou-se uma força de 4,1 tf, equivalente ao semi-eixo padrão rodoviário brasileiro, aplicada em uma área circular com $30 \mathrm{~cm}$ de diâmetro. 
Os deslocamentos gerados na superfície do pavimento (deflexões) são medidos por sete geofones (com capacidade máxima de medição de $2 \mathrm{~mm}$ ) instalados na placa de carga e ao longo de uma barra metálica de 2,25m de comprimento, a qual é abaixada automaticamente com a placa de carga (DYNATEST INC, 1995).

Não somente neste equipamento, mas também em todos seus congêneres, a distância de cada geofone ao centro da placa de carga deve ser fixada visando maximizar a acurácia, em função da estrutura do pavimento ensaiado, procurando posicioná-los de forma que as deflexões neles registradas reflitam a contribuição das diversas camadas na deformabilidade do pavimento e que o último seja instalado numa distância tal que a geometria da bacia fique completamente definida.

A diferença na geometria das bacias devido à rigidez dos diversos tipos de pavimento é mais significativa até $60-90 \mathrm{~cm}$ da placa de carga, e recomenda-se uma configuração de sensores nas seguintes distâncias em relação ao local de aplicação da carga: $0,20,30,45,60,90$ e $150 \mathrm{~cm}$ para pavimentos flexíveis e rígidos (SHRP, 1989).

Entretanto, nos estudos de caso em questão, o sétimo geofone foi posicionado a 120 cm do ponto de aplicação da carga. Este tipo de ajuste deve ser realizado caso a caso, conforme previsto na norma DNER-PRO 273/96.

No presente estudo a altura de queda foi ajustada, em todos os levantamentos, de forma a permitir que a carga final igual à de um semi-eixo padrão rodoviário, ou seja, 4,1 tf.

As informações dos sete geofones, da célula de carga e os sinais de controle são enviadas ao processador de sinais através de um cabo de sinais múltiplos. Este processador transforma cada sinal analógico em digital e as transmite ao computador que grava as informações obtidas e controla toda operação do ensaio. Pela tela do 
computador pode-se observar a variação ao longo do tempo das deflexões lidas nos geofones, além da forma do pulso de carga aplicado (figura 3.11). Verifica-se que o pulso de carga tem duração de cerca de $30 \mathrm{~ms}$, o que equivale aproximadamente a um veículo em movimento a $70 \mathrm{~km} / \mathrm{h}$. Verifica-se também que o pico das deflexões apresenta uma defasagem em relação à carga e que é tanto maior quanto mais afastado se encontra o geofone do centro da placa de carregamento. Este efeito é significativo até mesmo em pavimentos rígidos onde o atraso de fase é bem menor que nos pavimentos flexíveis e, provavelmente, caracteriza o comportamento viscoelástico dos materiais da estrutura analisada (MACÊDO, 1996).

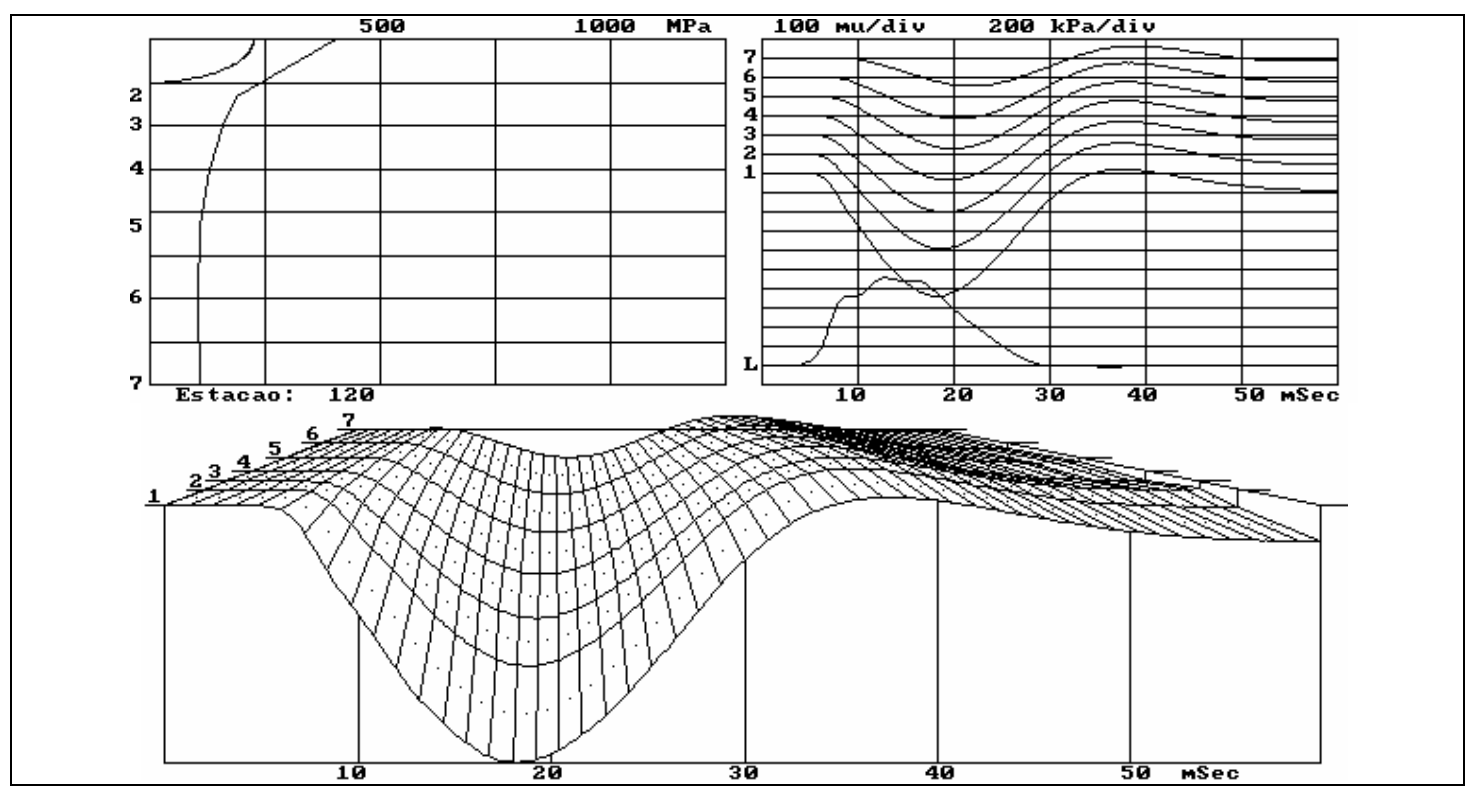

Figura 3.11 - Bacia de deflexões medida com o FWD (DYNATEST INC, 1995)

O conjunto de dados medidos (valores de pico das respostas) é mostrado no monitor do computador para inspeção, sendo em seguida armazenado em disco magnético e/ou enviado para a impressora com as identificações necessárias. O equipamento também registra a posição do ensaio e as temperaturas da superfície do pavimento e do ambiente.

A parte esquerda superior da figura anterior mostra a "rigidez total" do pavimento através de um módulo equivalente calculado como se o pavimento fosse um semiespaço elástico homogêneo, em termos de deflexão. Este módulo é calculado sob cada geofone pela formulação da teoria da elasticidade: 


$$
E=\frac{\sigma \cdot\left(1-\mu^{2}\right) a^{2}}{r \cdot d(r)}
$$

Onde:

$\sigma$ - pressão aplicada, em $\mathrm{kgf} / \mathrm{cm}^{2}$;

a - raio da área carregada, em cm;

r - distância radial, em cm;

$\mu$ - coeficiente de Poisson, adimensional;

d(r) - deflexão, na distância r, em cm

Este gráfico permite detectar rapidamente, após análise qualitativa ainda em campo, alguma anomalia na bacia de deflexões, caso em que se pode repetir o ensaio ou anotar alguma observação julgada pertinente à situação encontrada.

O procedimento de ensaio é realizado na seguinte seqüência:

i. Move-se o trailer para o local do ensaio, e posiciona-se o FWD na estação desejada, geralmente na trilha de roda externa;

ii. Liga-se o microcomputador e o processador que ficam na cabine do veículo rebocador;

iii. Seleciona-se a configuração de massas a ser utilizada na campanha de ensaios, fixando-a nos locais apropriados;

iv. Aciona-se no microcomputador o programa de campo, que permite, definido o tipo de ensaio desejado, realizar todas operações, incluindo abaixamento da placa de carga e da barra de geofones, elevação dos pesos para altura de queda pré-determinada, liberação dos pesos para a queda e, finalmente, a elevação da placa conjuntamente com a barra de sensores para $o$ deslocamento do equipamento em direção ao próximo ponto de medida. A operação completa pode ser controlada por uma pessoa situada no veículo rebocador e uma seqüência de ensaio dura 45 segundos em média.

v. A cada golpe programado e aplicado vão sendo exibidos em tela, na linha relativa a altura de queda, o pico de pressão na placa, a força correspondente 
e os picos de deflexão registrados em cada geofone. Concluída a seqüência de golpes, a placa e os sensores são suspensos hidraulicamente e o sistema emite um sinal sonoro ("beep") indicando que o trailer pode ser deslocado para a próxima estação de ensaio.

\subsubsection{Irregularidade Longitudinal}

As condições de conforto são avaliadas através da medição da irregularidade associada à via. Irregularidade é definida como sendo "o desvio da superfície da rodovia em relação a um plano de referência, que afeta a dinâmica dos veículos, a qualidade de rolamento e as cargas dinâmicas sobre a via" (DNER-PRO 182/94, 1994).

Adota-se como escala padrão de irregularidade no Brasil o Quociente de Irregularidade (QI), expresso em contagens por quilômetro, sendo esta medida, de acordo com PATERSON (1987) correlacionada com o International Roughness Index (IRI), expresso em metros por quilômetro, através da seguinte equação:

$$
I R I=\frac{Q I}{13}
$$

Para as determinações da irregularidade, ou do quociente de irregularidade, no trecho em questão, empregou-se medidor do tipo resposta instalado em um veículo que, ao deslocar-se sobre a via, fornece uma série de leituras que representam o somatório dos deslocamentos verticais retificados (isto é, em valores absolutos) do eixo traseiro do veículo em relação à carroçaria do mesmo (DNER-PRO 182/94, 1994).

Em todas as campanhas de avaliação foram empregados medidores totalmente informatizados, ligado ao hodômetro digital devidamente calibrado, que lhe permite registrar, além da distância percorrida, as velocidades média e instantânea do 
veículo-teste, contribuindo para que o operador tenha maior controle sobre o levantamento.

À medida que o levantamento é realizado, informações como distância percorrida, velocidade média e leituras são automaticamente gravadas em um arquivo no disco rígido do computador que controla todo o sistema, sem a interferência do operador.

O procedimento metodológico da avaliação passa pelas seguintes etapas:

- Posicionamento do veículo-teste na faixa de tráfego a ser avaliada, acerca de quinhentos metros do início do trecho;

- Liga-se o veículo-teste e, a duzentos metros de início do trecho, faz-se com que ele adquira velocidade constante;

- Quando o veículo-teste passa pelo ponto de início do trecho, aciona-se o dispositivo medidor;

- Os registros são realizados em intervalos pré-determinados, de acordo com a calibração realizada;

- Desliga-se o medidor na posição final.

Destaca-se que, durante a execução do levantamento, a pista deve estar livre e as rodas do lado direito do veículo-teste devem estar posicionadas na trilha de roda. Convém ressaltar que pode haver a necessidade de mudança de velocidade de percurso de acordo com a variação do fluxo de tráfego, entretanto a velocidade com que foi realizada a medição é devidamente registrada.

A velocidade de operação pode ser estabelecida de acordo com as condições de tráfego e superfície, havendo para cada velocidade, uma equação de calibração. No presente estudo, sempre que possível, as avaliações foram procedidas a $80 \mathrm{~km} / \mathrm{h}$, velocidade para a qual o equipamento e os modelos foram concebidos.

Por se tratar de um equipamento do tipo resposta, faz-se necessário o conhecimento das curvas de calibração nas possíveis velocidades de levantamento, de forma a permitir o cálculo do Quociente de Irregularidade (QI) de cada trecho. 
O procedimento de calibração consiste na realização de cinco passagens sobre trechos de referência, ou seja, segmentos rodoviários cujo QI foi determinado preliminarmente pelo Método de Nível e Mira, de forma a estabelecer a equação de regressão baseada nos valores de irregularidade (QI) e nas leituras médias conhecidas (L) para cada uma das velocidades pré-estabelecidas. Dessa forma, para cada velocidade de operação, têm-se determinadas as constantes da equação genérica:

$$
\mathrm{QI}=\mathrm{a}+\mathrm{bL}+\mathrm{c} \mathrm{L}^{2}
$$

Pode-se, através desta equação, ser calculada a irregularidade do pavimento a partir das leituras avaliadas com o equipamento tipo resposta (DNER-PRO 164/94, 1994).

\subsubsection{Inventário de Superfície}

Para realização do Inventário de Superfície foi realizado o Levantamento Visual Detalhado (LVD). Este levantamento tem o objetivo de analisar a condição de superfície dos pavimentos (pista de rolamento e acostamento) de maneira detalhada, sendo realizado por técnicos que locam e caracterizam os defeitos existentes no pavimento da pista e do acostamento em ficha específica, determinando as áreas com presença de trincamentos, remendos, panelas, erosões, afundamentos, etc., ou seja, cadastrando as áreas em que há necessidade de intervenção, subsidiando a definição de soluções de recuperação e manutenção.

As áreas críticas (com defeitos) são identificadas em uma ficha que contém o croqui representativo de um segmento de 1000 metros, com subdivisões de $100 \mathrm{~m}$. Nesta ficha tem-se também uma planilha onde são apontados os defeitos, suas localizações e dimensões, bem como observações e comentários julgados necessários para a avaliação e diagnóstico do segmento correspondente.

\subsubsection{Aderência}


A segurança em uma rodovia está associada a muitos fatores tais como sinalização horizontal e vertical, traçado, existência de objetos na pista, etc. Porém, no que diz respeito ao pavimento, a segurança, basicamente, trata da interação entre o pneu e o revestimento, que é definida pela resistência à derrapagem, representada pelos níveis de atrito da pista.

A avaliação de segurança de um pavimento refere-se à determinação de sua condição de aderência, quantificando e qualificando, através de ensaios e metodologia apropriada e reconhecida internacionalmente, a micro e a macrotextura do pavimento, parâmetros que influem diretamente na aderência entre pneu e pavimento (DNER, 1998).

A resistência à derrapagem entre as superfícies de um pneumático e de um revestimento de pavimento é uma grandeza que interfere diretamente na segurança dos usuários de veículos e pedestres, uma vez que determina a distância necessária para a parada do veículo durante a frenagem, ou sua permanência na trajetória em curvas horizontais.

A aderência entre pneu e pavimento é determinada pelo coeficiente de atrito característico do contato entre as duas superfícies. O coeficiente de atrito é função da força normal atuando no contato e da aspereza das superfícies dos pneumáticos e dos pavimentos.

A avaliação da aderência foi realizada com base na medida do coeficiente de atrito pelo Pêndulo Britânico, atendendo-se à especificação da ASTM E 303 -93, e pelo ensaio de mancha de areia. As medidas realizadas por estes dois ensaios foram feitas no final do estudo do trecho; não há informações referentes às condição de aderência previamente à restauração da via.

O princípio de medição do coeficiente de atrito pelo Pêndulo Britânico consiste em liberar-se o braço do pêndulo de uma determinada altura. Dessa maneira, a sapata revestida de borracha, localizada no final do braço, desliza sobre a superfície 
previamente molhada do pavimento, simulando assim a passagem do pneu de um veículo a $50 \mathrm{~km} / \mathrm{h}$. Mede-se então, na escala existente no equipamento, a altura máxima a qual chega o braço, após a sapata deslizar sobre a pista (ASTM E 303-93, 1998). A figura 3.12 ilustra o Pêndulo Britânico (ASTM E 3003-93, 1998).

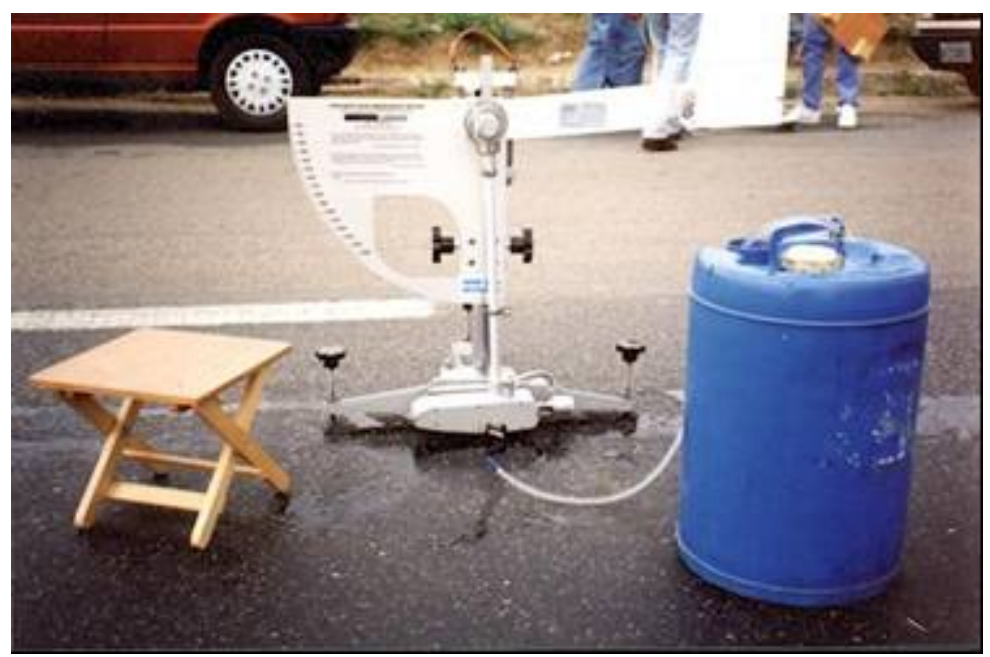

Figura 3.12 - Pêndulo britânico

Ressalta-se que a superfície é molhada antes de se executar o ensaio e os resultados são corrigidos em função da temperatura do pavimento molhado, a fim de se simular a situação crítica quanto à aderência e de se evitar erros no resultado, respectivamente.

Os ensaios de Mancha de Areia (Figura 3.13) consistem na distribuição de quantidade de $25.000 \mathrm{~mm}^{3}$ de areia padronizada quanto à graduação na superfície do pavimento com movimentos circulares, até que o material recubra a maior área possível do revestimento de modo que fiquem expostos somente as extremidades superiores dos agregados que mais se sobressaem. A medição do diâmetro deste círculo permite a determinação da espessura de areia existente nos "canais" formados entre agregados expostos, visto que o volume despejado é conhecido. Relaciona-se a espessura ou altura média de mancha de areia com a macrotextura superficial (DNER, 1998).

O cálculo da altura média HS de mancha de areia em mm é feita pela expressão: 


$$
H S=\frac{25.000}{\frac{\pi D^{2}}{4}}
$$

Onde:

$$
\begin{aligned}
& \mathrm{HS}=\text { profundidade Média de Areia }(\mathrm{mm}) \\
& \mathrm{D}=\text { diâmetro da mancha }(\mathrm{mm}) ;
\end{aligned}
$$

A avaliação das condições de segurança pela medida do Pêndulo Britânico em termos de aderência pneu-pavimento, ou resistência à derrapagem, estão resumidas na Tabela 3.8.

Tabela 3.8 - Classificação da condição da via a partir dos valores de VRD

\begin{tabular}{|c|c|}
\hline $\begin{array}{c}\text { Valores de Resistência à Derrapagem } \\
\text { (VRD) }\end{array}$ & Classe da Pista \\
\hline$<25$ & Perigosa (Extremamente Lisa) \\
$25-31$ & Muito Lisa \\
$32-39$ & Lisa \\
$40-46$ & Insuficientemente Rugosa \\
$47-54$ & Medianamente Rugosa \\
$55-75$ & Rugosa (Áspero) \\
$>75$ & Muito Rugosa (Muito Áspero) \\
\hline
\end{tabular}

Já os conceitos de macrotextura podem ser definidos a partir da profundidade média de areia, conforme a tabela 3.9. 


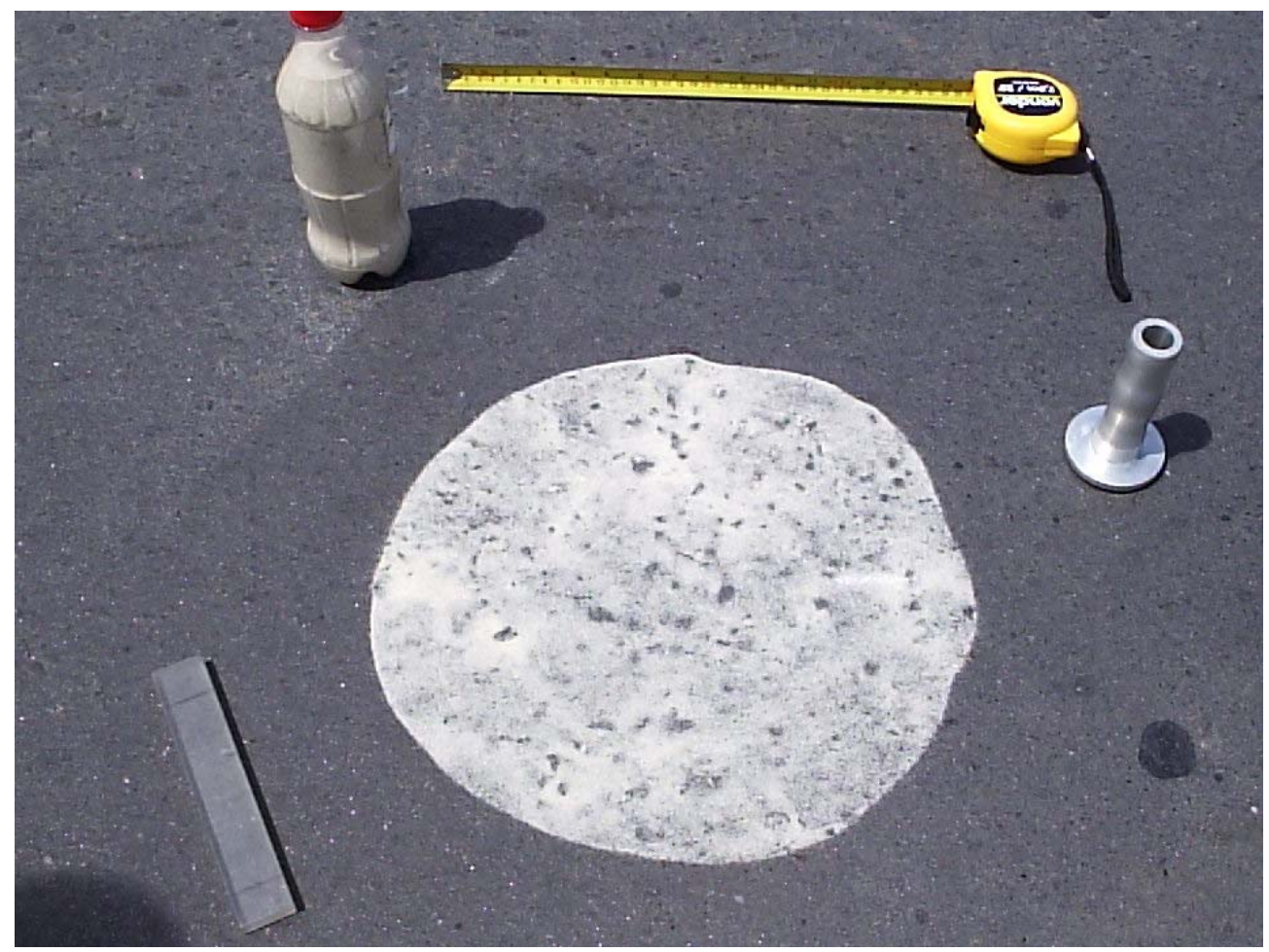

Figura 3.13 - Ensaio da Mancha de Areia

Tabela 3.9 - Classificação da condição da via a partir da profundidade de areia

\begin{tabular}{|c|c|}
\hline Profundidade Média de Areia - HS (mm) & Classe da Pista \\
\hline $\mathrm{HS} \leq 0,20 \mathrm{~mm}$ & Muito Fina ou Muito Fechada \\
$0,20 \mathrm{~mm}<\mathrm{HS} \leq 0,40 \mathrm{~mm}$ & Fina ou Fechada \\
$0,40 \mathrm{~mm}<\mathrm{HS} \leq 0,80 \mathrm{~mm}$ & Média \\
$0,80 \mathrm{~mm}<\mathrm{HS} \leq 1,20 \mathrm{~mm}$ & Grosseira ou Aberta \\
$\mathrm{HS}>1,20 \mathrm{~mm}$ & Muito Grosseira ou Muito Aberta \\
\hline
\end{tabular}




\section{ESTUDO DE CASO EM LABORATÓRIO}

Para a elaboração do estudo de caso em laboratório foram realizadas diversas modificações de ligantes asfálticos dos tipos CAP20 e CAP40 com distintos teores de polímero RET ( $1 \%, 1,5 \%$ e $2 \%$ - em peso do CAP) com posterior dosagem de uma mistura na Faixa III do DERSA no teor de RET considerado como mais adequado para cada um dos tipos de ligante estudados.

\subsection{ESTUdO DE LigANTES}

Para o presente estudo foram utilizados os ligantes asfálticos dos tipos CAP $20^{1}$ e CAP $40^{2}$ provenientes, respectivamente, das refinarias do Vale do Paraíba (REVAP em São José dos Campos) e do Paraná (REPAR em Araucária). As modificações realizadas em laboratório encontram-se listadas abaixo:

- CAP $20+1,0 \%$ de Polímero RET + 0,22\% de Catalizador $\mathrm{H}_{3} \mathrm{PO}_{4}$;

- CAP $20+1,5 \%$ de Polímero RET + 0,22\% de Catalizador $\mathrm{H}_{3} \mathrm{PO}_{4}$;

- CAP $20+2,0 \%$ de Polímero RET + 0,22\% de Catalizador $\mathrm{H}_{3} \mathrm{PO}_{4}$;

- CAP $40+1,0 \%$ de Polímero RET + 0,22\% de Catalizador $\mathrm{H}_{3} \mathrm{PO}_{4}$;

- CAP $40+1,5 \%$ de Polímero RET + 0,22\% de Catalizador $\mathrm{H}_{3} \mathrm{PO}_{4}$;

- CAP $40+2,0 \%$ de Polímero RET + 0,22\% de Catalizador $\mathrm{H}_{3} \mathrm{PO}_{4}$;

Os passos para a modificação do ligante asfáltico em laboratório são bastante simples sendo necessários, para tanto, o aquecimento e a agitação direta conforme detalhado nos nove passos a seguir:

\footnotetext{
${ }^{1}$ Atualmente pela classificação dos ligantes asfálticos, em vigor a partir de julho de 2005, o CAP 20 corresponderia ao CAP 50/70.

${ }^{2}$ Atualmente pela classificação dos ligantes asfálticos, em vigor a partir de julho de 2005, o CAP 40 corresponderia ao CAP 30/45.
} 
1. Aquecer cuidadosamente a amostra de asfalto até que a mesma se encontre suficientemente fluida para poder ser trabalhada (geralmente à $175^{\circ} \mathrm{C}$ );

2. Agitar a amostra até que a mesma se torne homogênea;

3. Vertê-la dentro de um recipiente adequado para a mistura;

4. Inserir o recipiente de asfalto em um agitador e elevar a temperatura entre $185^{\circ} \mathrm{C}$ e $190^{\circ} \mathrm{C}$

5. Agitar a amostra de forma rápida o suficiente para formar um pequeno vórtice, sem permitir a entrada excessiva de ar na amostra;

6. Adicionar lentamente o polímero RET (aproximadamente $10 \mathrm{~g} /$ minuto), no teor desejado;

7. Agitar a amostra durante 1 hora, mantendo a temperatura entre $185^{\circ} \mathrm{C}$ e $190^{\circ} \mathrm{C}$. (Para manter o nível adequado de agitação a velocidade do agitador deve ser aumentada em função da variação da viscosidade do ligante asfáltico);

8. Adicionar $0,22 \%$ (porcentagem em peso de asfalto) do Catalisador $\mathrm{H}_{3} \mathrm{PO}_{4}$ Ácido Polifosfórico à mistura, tomando cuidado de adicionar o ácido depois que se tenha dissolvido todo o polímero, caso contrário o mesmo não se dissolverá mais no asfalto e podem se formar grumos.

9. Agitar por 30 minutos adicionais a mistura de cimento asfáltico, RET e o catalisador.

O equipamento utilizado para a produção das amostras dos ligantes asfálticos empregados na presente pesquisa foram um termômetro, uma furadeira com controle de velocidade de rotação, um hélice adaptada à furadeira para promover a mistura, um suporte e um recipiente metálico, apresentados na Figura 4.1. 


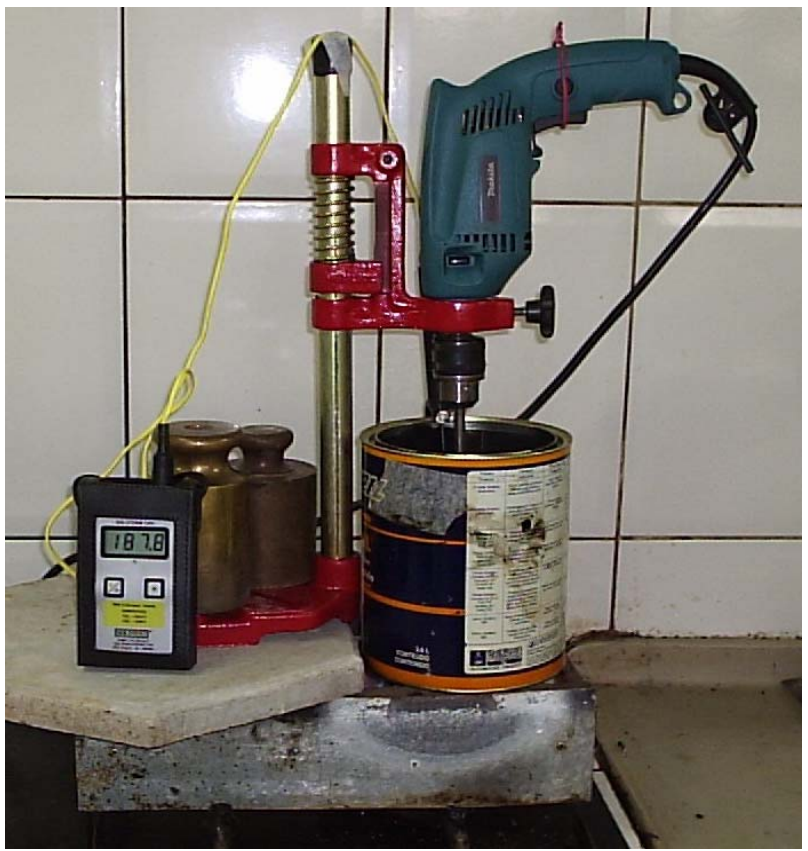

Figura 4.1 - Equipamento para Modificação em Laboratório

Após a sua modificação com polímero, os ligantes asfálticos foram caracterizados fisicamente, sendo os resultados detalhados na seqüência para cada tipo de ensaio empregado.

\section{- Penetração}

O ensaio de Penetração isoladamente não caracteriza perfeitamente a qualidade de um cimento asfáltico, contudo, constitui uma indicação do seu grau de dureza, sendo utilizado em algumas especificações como parâmetro de classificação. No CAP 20, com a adição de $1 \%$ de polímero RET a penetração foi de $60 \times 0,1 \mathrm{~mm}$ (ligante puro) para 49x0,1mm (ligante modificado com 1\% de RET) e nas modificações subseqüentes com $1,5 \%$ e $2 \%$ a redução foi menos significativa, com valores de $47 \times 0,1 \mathrm{~mm}$ e $42 \times 0,1 \mathrm{~mm}$, respectivamente.

Para o CAP 40, a adição de $1,0 \%$ de RET não alterou significativamente a Penetração; já as modificações com 1,5\% e 2,0\% representaram uma redução de $32 \times 0,1 \mathrm{~mm}$ para $17 \mathrm{x} 0,1 \mathrm{~mm}$ e $25 \times 0,1 \mathrm{~mm}$, respectivamente. 
Os valores encontrados para a Penetração dos ligantes ensaiados são apresentados nas Figuras 4.2 e 4.3.

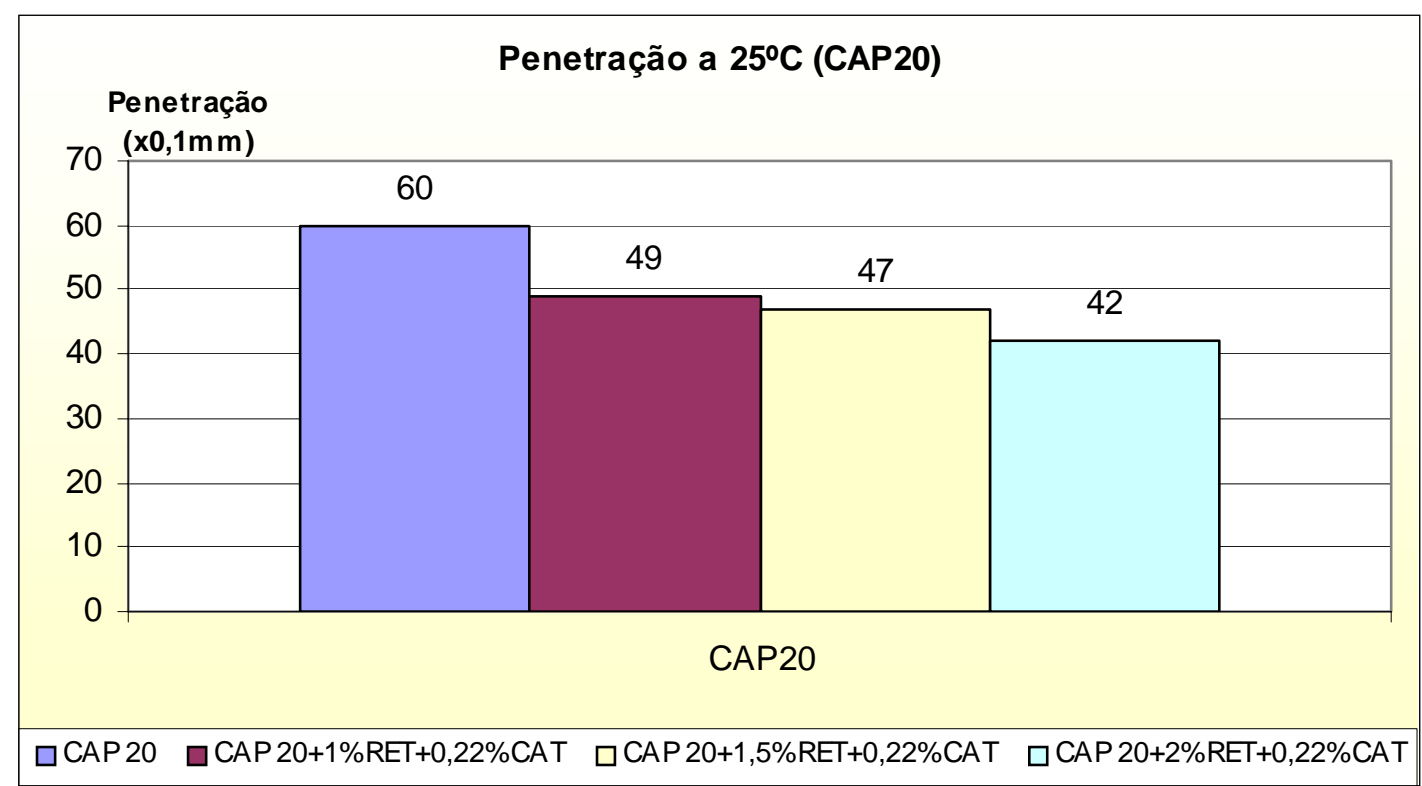

Figura 4.2 - Valores de Penetração para o CAP20 e modificados

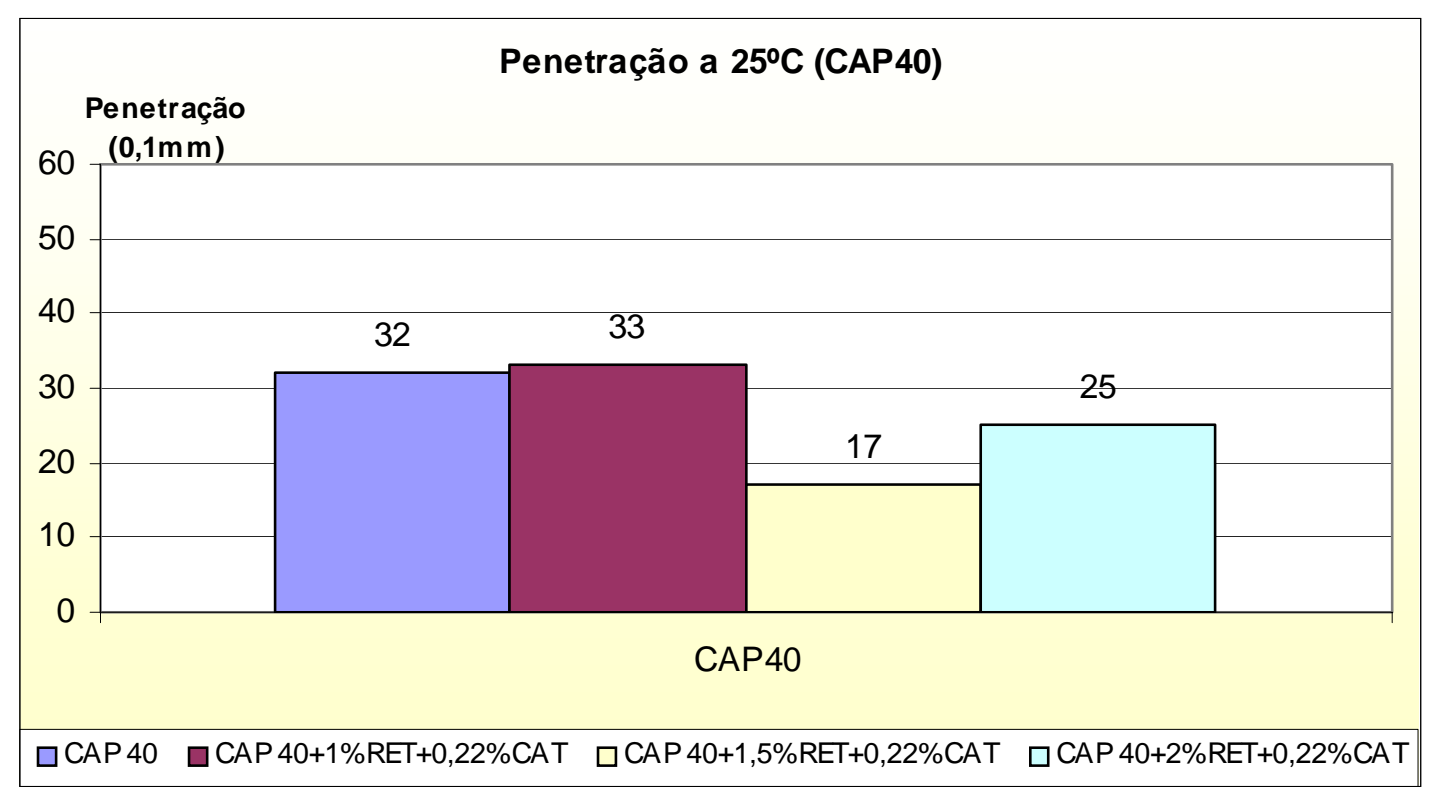

Figura 4.3 - Valores de Penetração para o CAP40 e modificados

\section{- Ponto de Amolecimento}

Os valores encontrados para o Ponto de Amolecimento dos ligantes ensaiados são apresentados na Figura 4.4. 


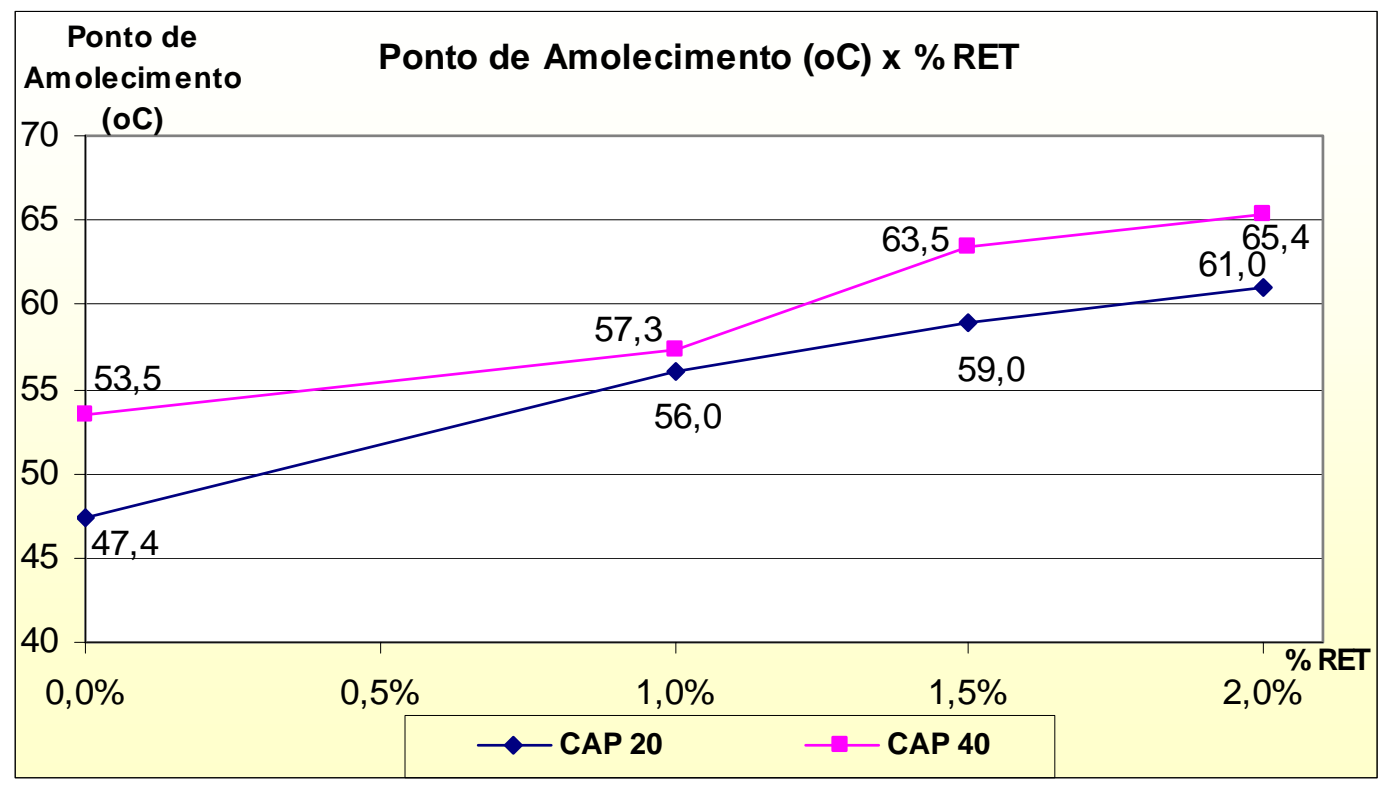

Figura 4.4 - Valores de Penetração para o CAP40 e modificados

Em ambos os asfaltos estudados (CAP 20 e CAP 40) quanto maior foi o teor de polímero adicionado, maior foi o Ponto de Amolecimento encontrado. Estes resultados são positivos no sentido de que quanto maior o Ponto de Amolecimento, maior a resistência à deformação permanente.

Além disso, observa-se que para o CAP 40 o acréscimo no ponto de amolecimento, quando o teor de polímero foi elevado de $1,5 \%$ para $2 \%$ foi muito pequeno, de $63,5 \%$ para $65,4 \%$, indicando uma tendência de estabilização deste parâmetro para teores de polímero mais elevados.

\section{- Ductilidade}

Todos os asfaltos modificados por polímero do Tipo RET tiveram uma redução no valor da Ductilidade quando comparados com os asfaltos convencionais. Para o CAP 20 houve uma redução significativa desta propriedade quando foi adicionado 1,5\%. Nas modificações subseqüentes as reduções foram menos significativas, sendo que o valor permaneceu quase estável quando se compara os ligantes modificados com 1,5 e $2,0 \%$ (ductilidades de $54 \mathrm{~cm}$ e $51 \mathrm{~cm}$, respectivamente). 
Para o CAP 40, a maior redução ocorreu quando se compara a modificação com $1,0 \%$ e $1,5 \%$ (queda na ductilidade de $96 \mathrm{~cm}$ para $36 \mathrm{~cm}$ ).

A maioria dos ligantes para pavimentação têm ductilidade superior a $50 \mathrm{~cm}$. Deve-se observar que o valor exato da ductilidade não é tão importante como o fato do material betuminoso ter que ser dúctil, ou seja, um asfalto com ductilidade $50 \mathrm{~cm}$ pode ser tão bom quanto um outro de ductilidade $150 \mathrm{~cm}$.

Evidentemente um valor de ductilidade menor que $10 \mathrm{~cm}$ está associado a um ligante oxidado por um aquecimento muito elevado ou a um envelhecimento em serviço do revestimento antigo.

Os valores encontrados para a Ductilidade a $25^{\circ} \mathrm{C}$ dos ligantes ensaiados são apresentados nas Figuras 4.5 e 4.6 .

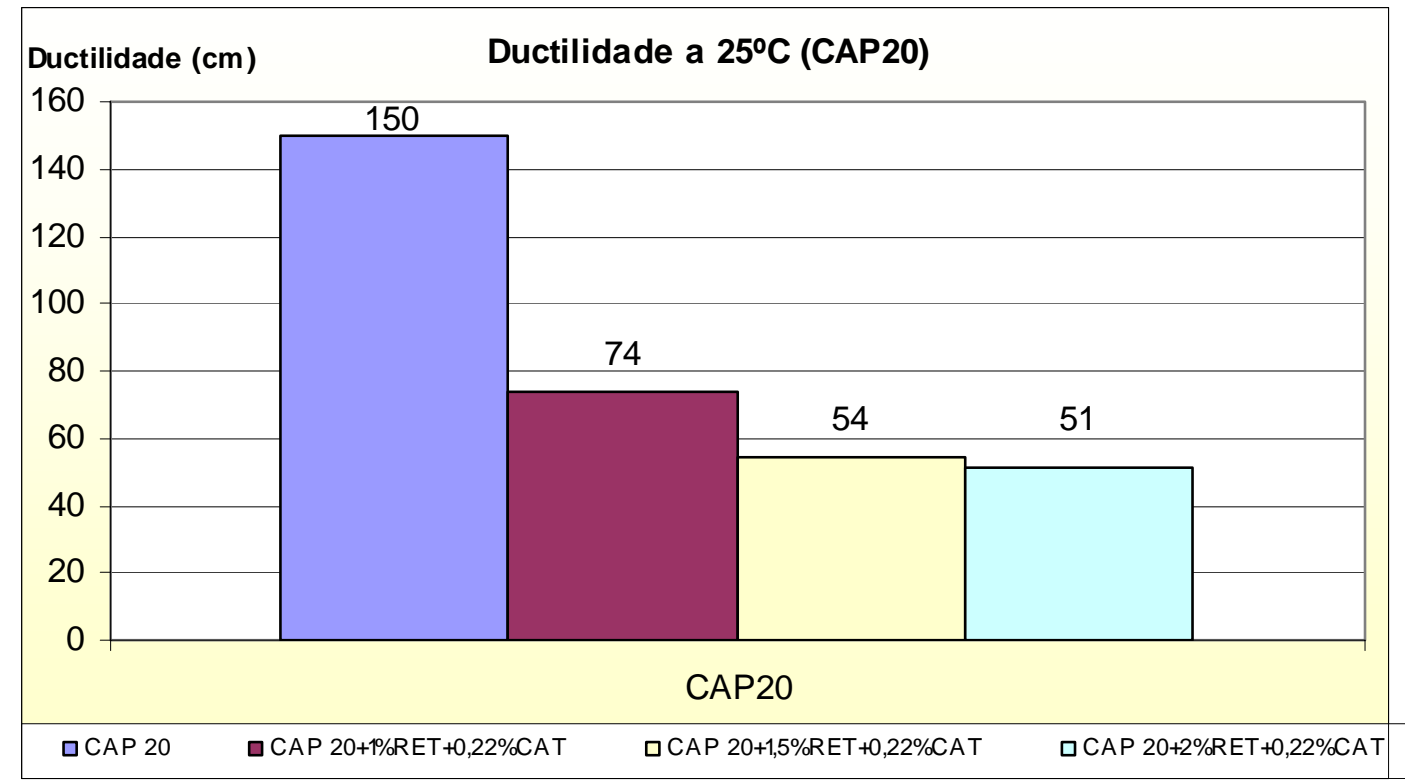

Figura 4.5 - Valores da Ductilidade para o CAP20 e Modificados 


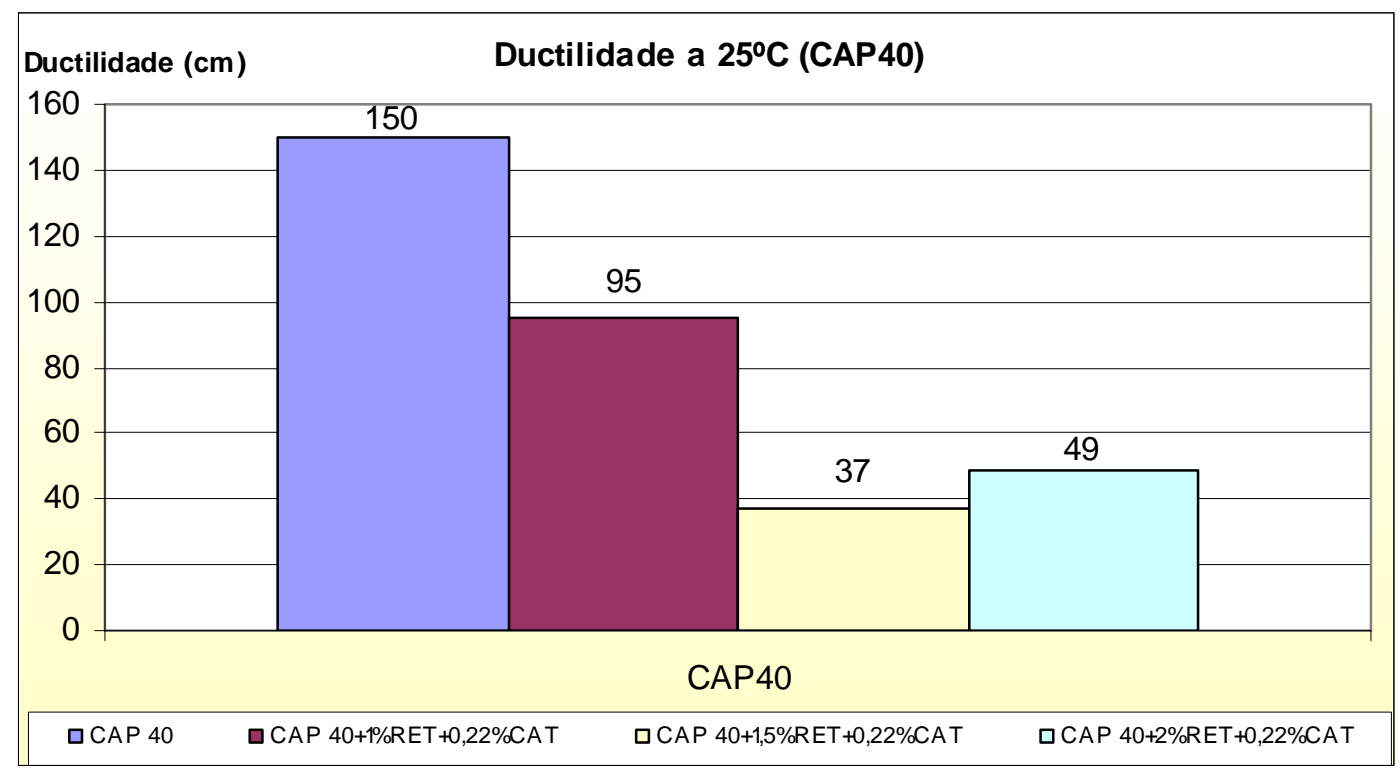

Figura 4.6 - Valores da Ductilidade para o CAP40 e Modificados

\section{- Ponto de Fulgor}

Os valores encontrados para o Ponto de Fulgor dos ligantes ensaiados são apresentados na Tabela 4.1.

Tabela 4.1 - Ponto de Fulgor dos Ligantes Ensaiados

\begin{tabular}{|c|c|c|c|}
\hline Ligante & $\begin{array}{c}\text { Ponto de } \\
\text { Fulgor } \\
(\text { oC) }\end{array}$ & Ligante & $\begin{array}{c}\text { Ponto de } \\
\text { Fulgor } \\
\text { (oC) }\end{array}$ \\
\hline CAP 20 & 260 & CAP40 & 275 \\
\hline CAP $20+1 \%$ RET $+0,22 \%$ CAT & 275 & CAP $40+1 \%$ RET $+0,22 \%$ CAT & 275 \\
\hline CAP $20+1,5 \%$ RET $+0,22 \%$ CAT & 280 & CAP $40+1,5 \%$ RET $+0,22 \%$ CAT & 280 \\
\hline CAP $20+2 \%$ RET $+0,22 \%$ CAT & 270 & CAP $40+2 \%$ RET $+0,22 \%$ CAT & 280 \\
\hline
\end{tabular}

O Ponto de Fulgor de qualquer um dos asfaltos estudados é superior a $240^{\circ} \mathrm{C}$, ou seja, todos eles apresentam características adequadas de segurança em termos de aquecimento a que este asfalto deve ser submetido em seu manuseio. Pode-se observar que, salvo o CAP 40 com 1\% de RET, os asfaltos modificados apresentam maior Ponto de Fulgor em comparação ao asfalto puro. Segundo Pinto (1998), alguns 
estudiosos acreditam que os ligantes com elevado ponto de fulgor têm elevada durabilidade, embora esta afirmação não esteja ainda comprovada.

\section{- Retorno Elástico}

Os valores encontrados para o Retorno Elástico, medido com o Ductilômetro a $25^{\circ} \mathrm{C}$ para os ligantes ensaiados são apresentados na Figura 4.7.

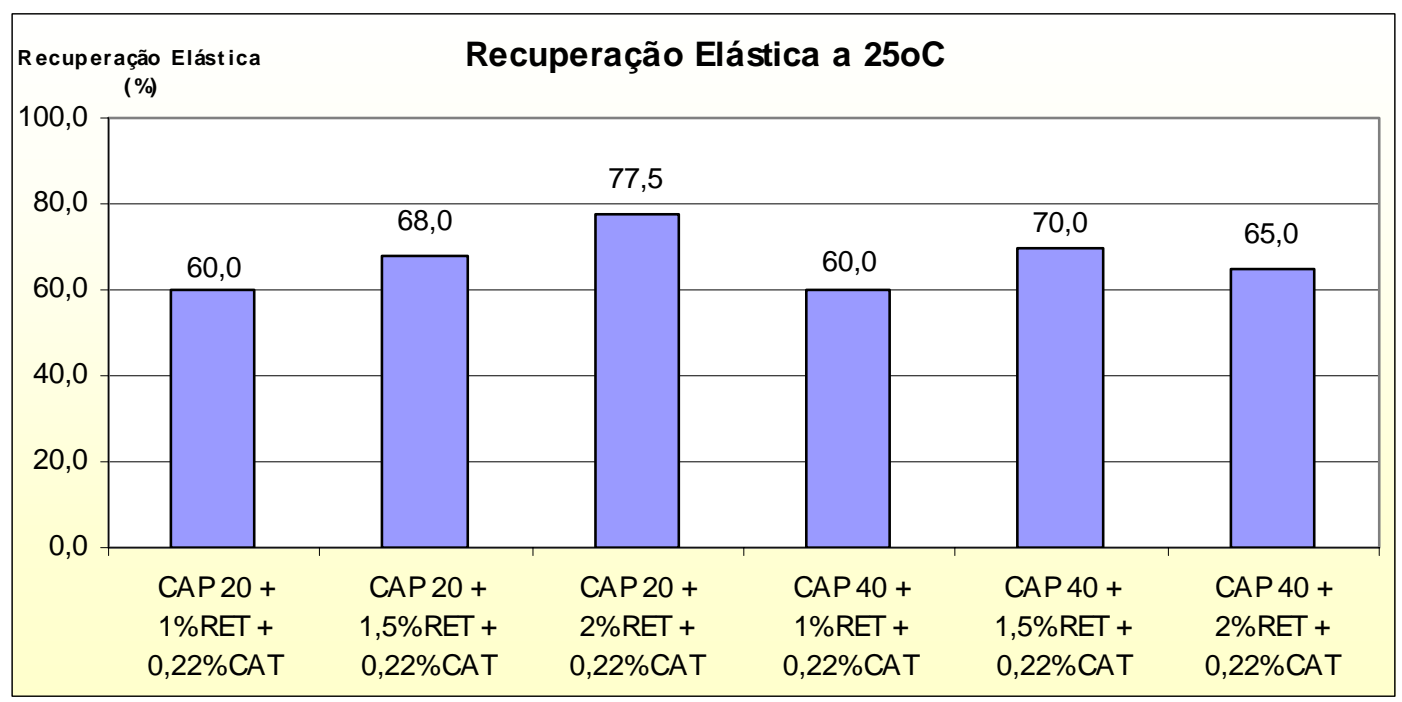

Figura 4.7 - Resultado dos Retornos Elásticos encontrados para os ligantes modificados testados

O Retorno Elástico encontrado para os asfaltos modificados oscilou entre 60 e $80 \%$, dependendo da quantidade e do tipo de asfalto estudado. Estes resultados representam uma melhora no comportamento reológico com relação ao ligante convencional, que apresenta Retorno Elástico desprezível (próximo de zero), indicando uma melhora da flexibilidade e da elasticidade dos asfaltos estudados.

Verifica-se que, mesmo com o aumento do teor de polímero no CAP 40 de 1,5\% para $2,0 \%$ houve uma redução no valor do retorno elástico de $70 \%$ para $65 \%$. Esta redução pode ser devido à saturação dos asfaltenos disponíveis para reagir quimicamente com o polímero RET. 
Quando ocorre esta saturação a adição de mais polímero acarreta em alteração de algumas propriedades do ligante como aumento de viscosidade ou do ponto de amolecimento, mas não melhora em termos elásticos, já que esta propriedade é diretamente influenciada pela ligação química entre o RET e o asfalto.

\section{- Viscosidade BrookField}

As Tabelas 4.2 e 4.3 e a representação gráfica dos valores nos resultados encontrados (Figura 4.8 e Figura 4.9) para as viscosidades medidas com o Viscosímetro Brookfield para diferentes temperaturas.

Tabela 4.2 - Viscosidade BrookField para diferentes Temperaturas (CAP20)

\begin{tabular}{|c|c|c|c|c|}
\hline \multirow{2}{*}{$\begin{array}{c}\text { Temperatura } \\
\left({ }^{\circ} \mathrm{C}\right)\end{array}$} & \multicolumn{4}{|l|}{ Viscosidade BrookField (cP) } \\
\cline { 2 - 5 } & CAP 20 & $\begin{array}{c}\text { CAP 20+1\%RET } \\
+0,22 \% \text { CAT }\end{array}$ & $\begin{array}{c}\text { CAP20+1,5\%RET } \\
+0,22 \% \text { CAT }\end{array}$ & $\begin{array}{c}\text { CAP20+2\%RET } \\
+0,22 \% \text { CAT }\end{array}$ \\
\hline 135 & 408 & 920 & 1.346 & 2.215 \\
145 & 250 & 542 & 768 & 1.220 \\
175 & 80 & 150 & 198 & 285 \\
\hline
\end{tabular}

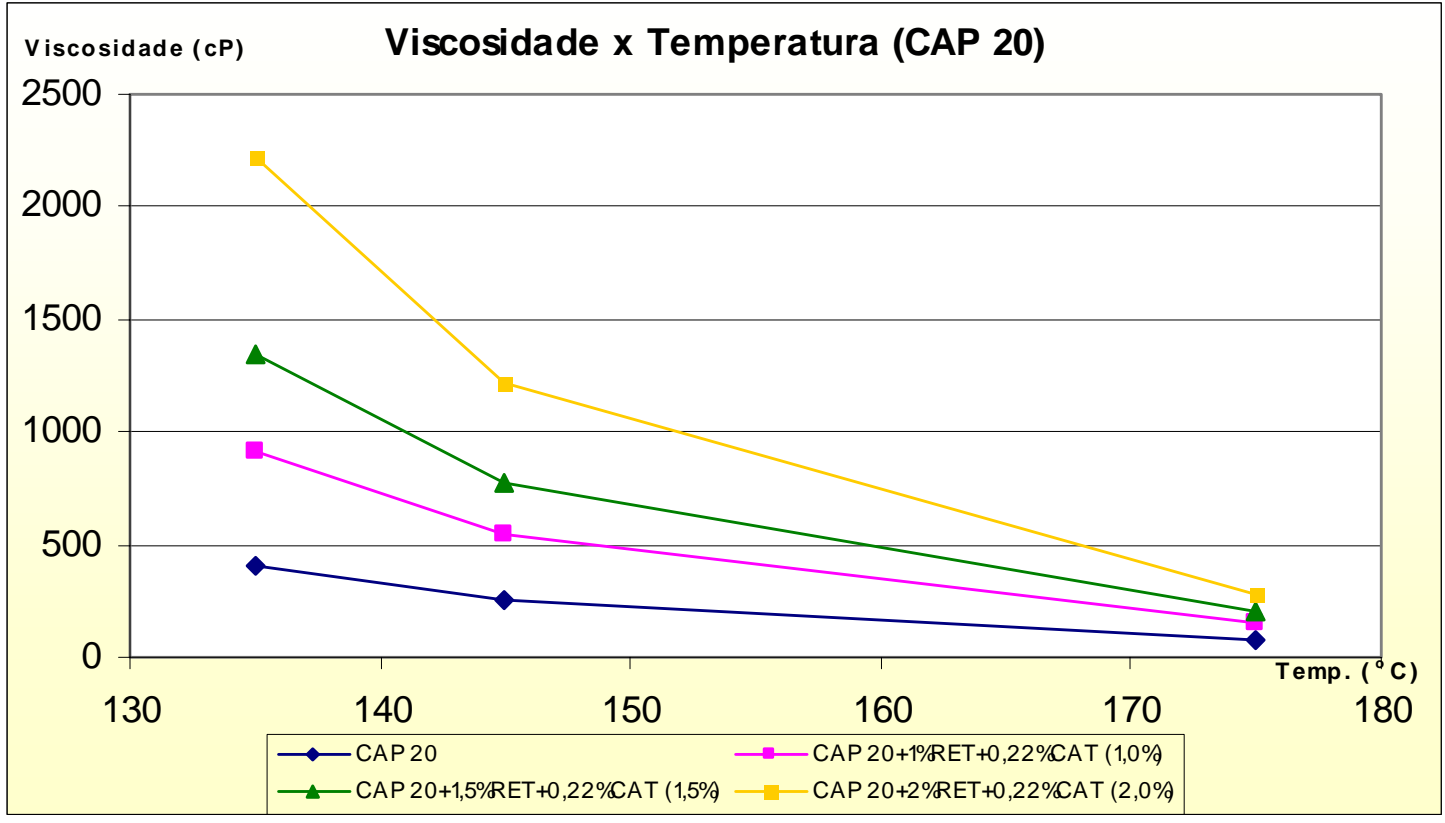

Figura 4.8 - Gráfico da variação da viscosidade em função da temperatura (CAP20) 
Tabela 4.3 - Viscosidade Brookfield para diferentes Temperaturas (CAP40)

\begin{tabular}{|c|c|c|c|c|}
\hline \multirow{2}{*}{$\begin{array}{c}\text { Temperatura } \\
\left({ }^{\circ} \mathrm{C}\right)\end{array}$} & \multicolumn{4}{|l|}{ Viscosidade BrookField (cP) } \\
\cline { 2 - 5 } & CAP 40 & $\begin{array}{c}\text { CAP 40+1\%RET } \\
+0,22 \% \text { CAT }\end{array}$ & $\begin{array}{c}\text { CAP40+1,5\%RET } \\
+0,22 \% \text { CAT }\end{array}$ & $\begin{array}{c}\text { CAP40+2\%RET } \\
+0,22 \% \text { CAT }\end{array}$ \\
\hline 135 & 458 & 860 & 1.730 & 1.987 \\
145 & 276 & 502 & 980 & 1.128 \\
175 & 82 & 140 & 244 & 282 \\
\hline
\end{tabular}

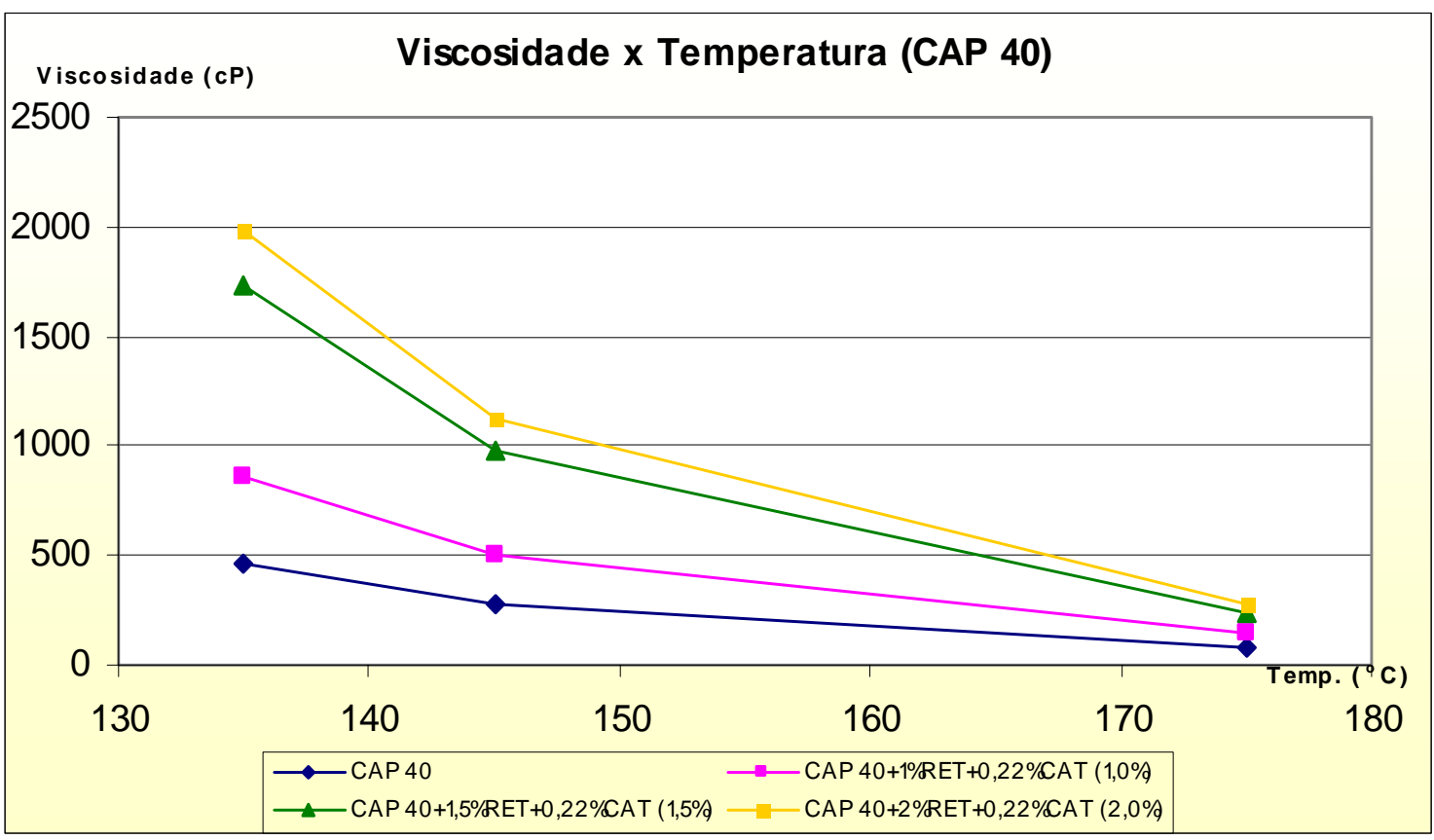

Figura 4.9 - Gráfico da variação da viscosidade em função da temperatura (CAP40)

Observa-se que os ligantes estudados sofreram uma alteração significativa em sua viscosidade com a adição do polímero RET, principalmente para temperaturas mais baixas. No caso do CAP 20, a viscosidade a $135^{\circ} \mathrm{C}$ passou de $408 \mathrm{cP}$ para $920 \mathrm{cP}$, ou seja, um aumento superior a $100 \%$, com a adição de apenas $1 \%$ de polímero. No CAP 40 , com o mesmo $1 \%$, o acréscimo foi de quase $90 \%$, com a viscosidade passando de $458 \mathrm{cP}$ para $860 \mathrm{cP}$.

Pela Figura 4.10 pode-se observar que quanto maior foi o teor de polímero utilizado, maiores foram as viscosidades aferidas numa dada temperatura. Destaca-se que, para 
o CAP 40, houve um aumento significativo de viscosidade quando o teor de polímero foi de $1 \%$ para $1,5 \%$ e um acréscimo não tão significativo quando o teor foi de $1,5 \%$ para $2 \%$. Já para o CAP20 a tendência de aumento da viscosidade com o aumento do teor de polímero foi progressiva.

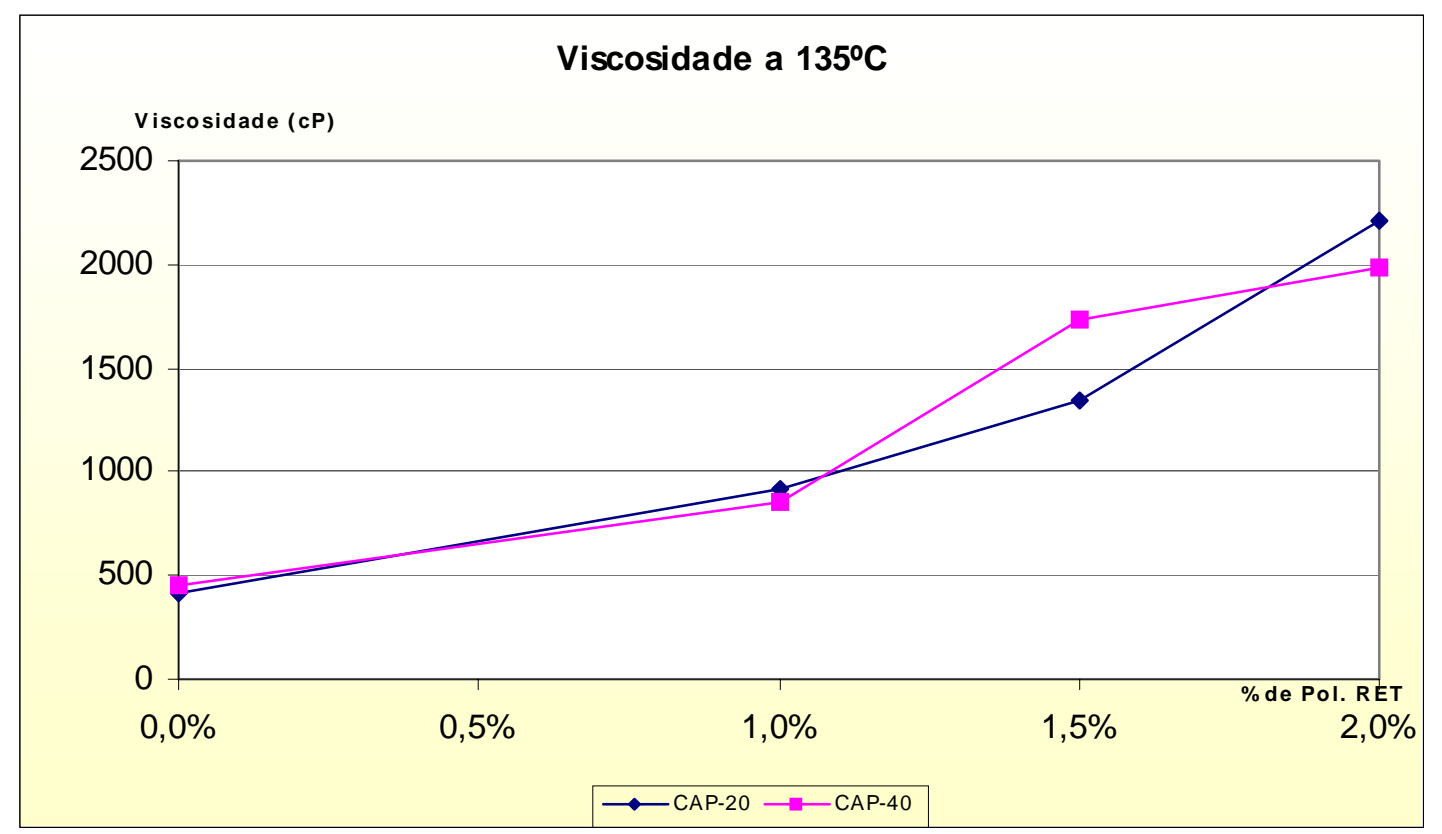

Figura 4.10 - Aumento da Viscosidade em função do teor de polímero $\left(135^{\circ} \mathrm{C}\right)$

\section{- Densidade}

A Tabela 4.4 apresenta os valores encontrados para as densidades nos diferentes tipos de ligantes. 
Tabela 4.4 - Densidades dos Ligantes Estudados

\begin{tabular}{|c|c|}
\hline Ligante & $\begin{array}{c}\text { Densidade a 20/4 } \\
\mathbf{( g / \mathbf { c m } ^ { \mathbf { } } \mathbf { C }}\end{array}$ \\
\hline CAP 20 & 1,017 \\
\hline CAP $20+1 \%$ RET $+0,22 \%$ CAT & 1,019 \\
\hline CAP $20+1,5 \%$ RET $+0,22 \%$ CAT & 1,018 \\
\hline CAP $20+2 \%$ RET $+0,22 \%$ CAT & 1,018 \\
\hline CAP 40 & 1,018 \\
\hline CAP $40+1 \%$ RET $+0,22 \%$ CAT & 1,018 \\
\hline CAP $40+1,5 \%$ RET $+0,22 \%$ CAT & 1,019 \\
\hline CAP $40+2 \%$ RET $+0,22 \%$ CAT & 1,019 \\
\hline
\end{tabular}

Observa-se que a densidade do asfalto não sofre alteração significativa com a adição do polímero em qualquer um dos teores estudados.

\section{- Efeito do Calor e do Ar}

Segundo a especificação ASTM D 1754 a variação máxima de massa que a amostra ensaiada pode sofrer no ensaio que simula o efeito do calor e do ar (ECA) é de 1\%, ou seja, $0,25 \mathrm{~g}$, e a relação entre a Penetração das amostras antes e após o ensaio do ECA deve ser superior a 50\%. As Figuras 4.11 e 4.12 apresentam os valores encontrados. 


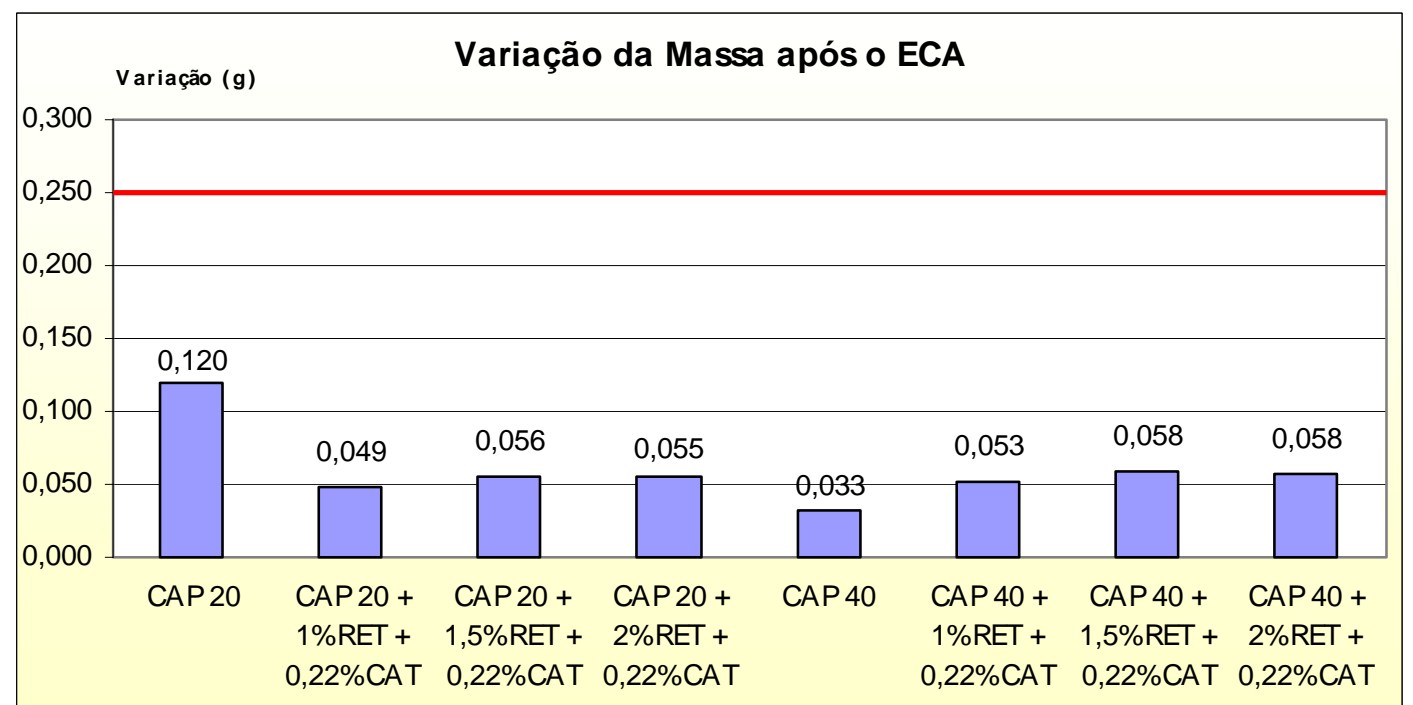

Figura 4.11 - Variação da Massa após o ensaio do ECA

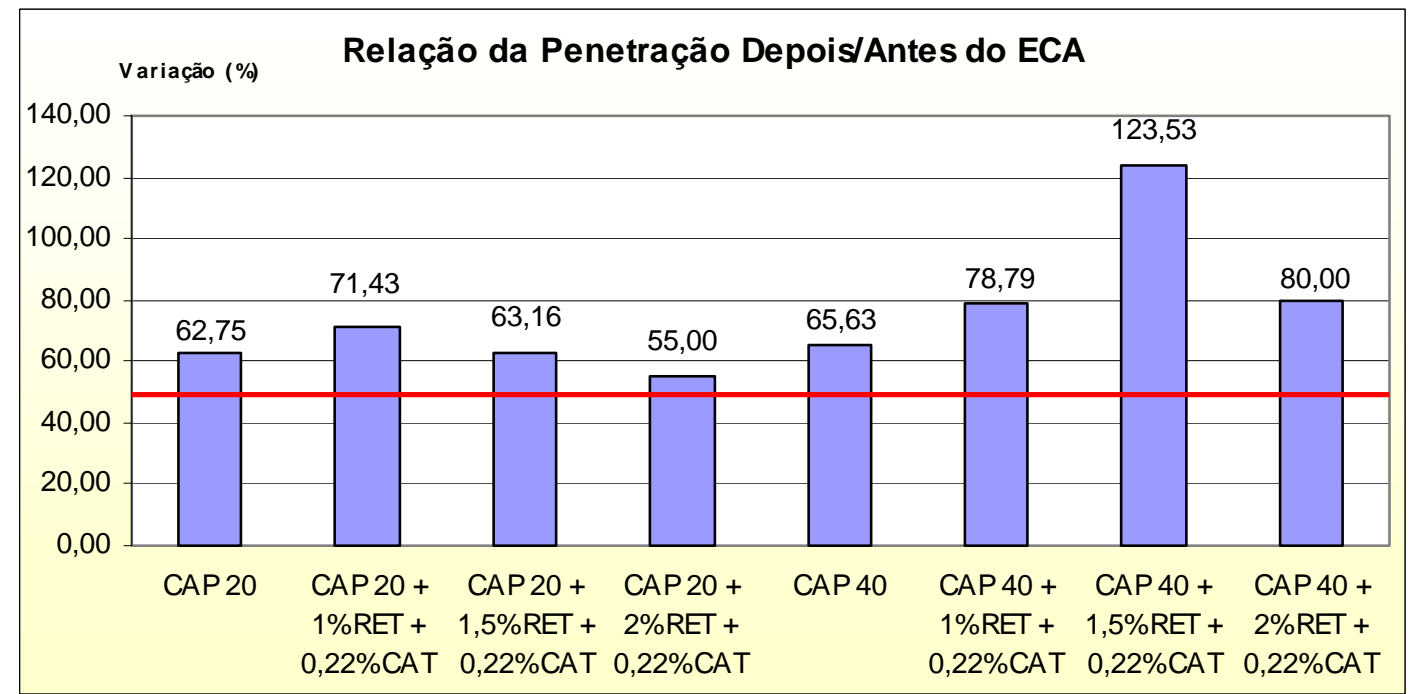

Figura 4.12 - Variação percentual da Penetração antes e depois do ECA

De acordo com os resultados apresentados todos os ligantes estudados apresentaram valores adequados de perda de massa e variação da penetração durante o ensaio que simula o efeito do calor e do ar no processo de usinagem da mistura asfáltica. 


\section{- Índice de Susceptibilidade Térmica (IST)}

O IST é o índice de suscetibilidade térmica de Pfeiffer e Vann Doormaal que nas especificações brasileiras para asfaltos convencionais pode variar de $(-1,5)$ a $(+1)$ até julho de 2005 , e que a partir desta data está limitado entre $(-1,5)$ a $(+0,7)$. Valores superiores a $(+1)$ indicam, em geral, asfaltos oxidados, ou seja, pouco sensíveis a elevadas temperaturas e quebradiços, ou frágeis, quando a temperatura é baixa; já os valores inferiores a (-2) indicam, em geral, asfaltos muito sensíveis a altas temperaturas, ou seja, que amolecem rapidamente. Os valores encontrados para o IST dos ligantes estudados são apresentados na Figura 4.13.

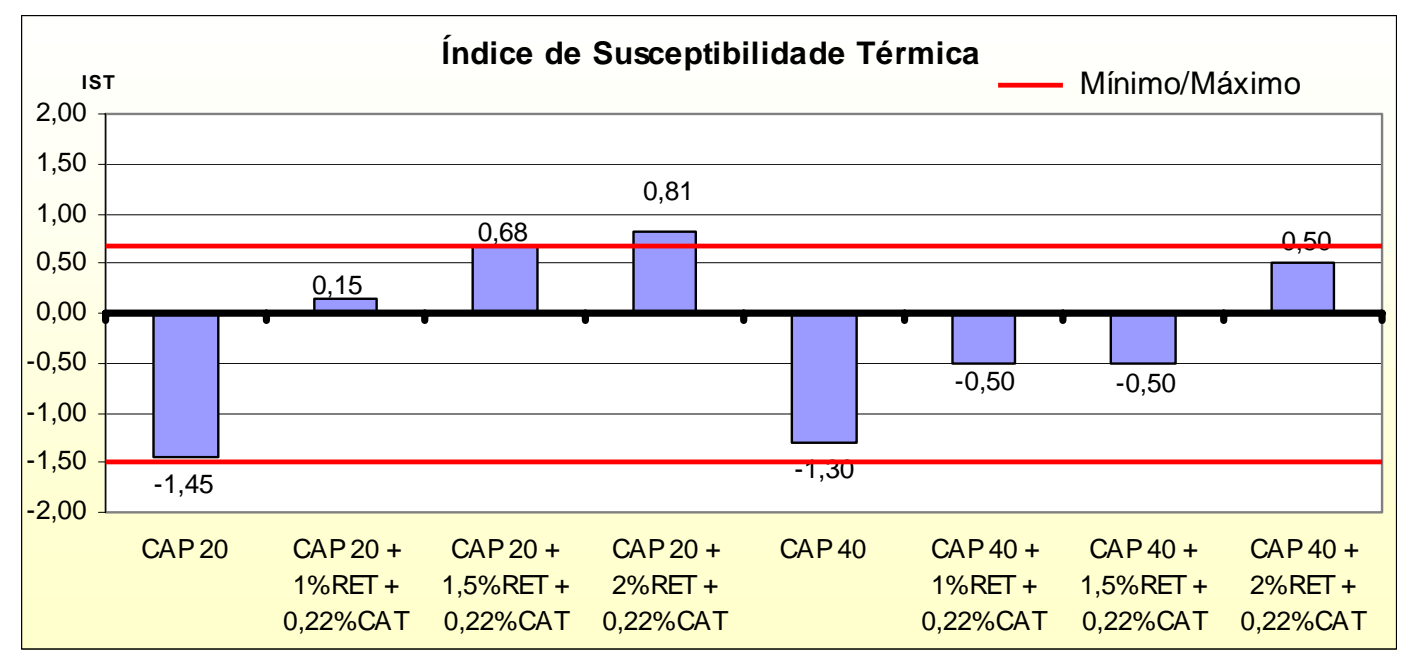

Figura 4.13 - IST dos ligantes Estudados

Observa-se que os valores do IST de todos os ligantes estudados, exceto para o CAP $20+2 \%$ RET $+0,22 \%$ CAT, ficaram dentro dos limites estabelecidos para asfaltos convencionais. Ressalta-se que os asfaltos modificados por polímero do Tipo RET são menos sensíveis a elevadas temperaturas (IST mais altos) do que os asfaltos convencionais e que, valores superiores 0,7 de IST para os asfaltos modificados, mesmo estando acima do recomendado para os asfaltos convencionais, não representam um problema, já que estes asfaltos são menos sensíveis a elevadas temperaturas sem serem quebradiços quando a baixas temperaturas. 


\section{- Escolha do Teor Ótimo de RET para elaboração das Misturas}

A determinação do Teor ótimo de Polímero RET para a elaboração da pesquisa em laboratório com as misturas asfálticas foi baseada nos resultados encontrados a partir ensaios de caracterização dos ligantes. Como não existe especificação brasileira que indique valores mínimos e/ou máximos para os parâmetros estudados no caso da utilização de polímero do tipo RET, procurou-se escolher o teor de polímero que melhor se adequasse com as características dos asfaltos modificados por polímero SBS contidas na especificação do DNER EM 396/99, levando-se em consideração, principalmente, os resultados de Viscosidade e Penetração. A Tabela 4.5 apresenta os resultados dos ensaios para os ligantes considerados como os mais adequados.

Tabela 4.5 - Escolha do Tipo de Ligantes - Ensaios Realizados

\begin{tabular}{|c|c|c|c|}
\hline Ensaio & $\begin{array}{c}\text { DNER EM } \\
396 / 99\end{array}$ & $\begin{array}{c}\text { CAP20 } \\
+1,5 \% \mathrm{RET} \\
+0,22 \% \mathrm{CAT}\end{array}$ & $\begin{array}{c}\text { CAP40 } \\
+1 \% \text { RET } \\
+0,22 \% \mathrm{CAT}\end{array}$ \\
\hline Viscosidade a $135^{\circ} \mathrm{C}(\mathrm{cP})$ & $>850$ & 1.346 & 860 \\
Penetração a $25^{\circ} \mathrm{C}(\mathrm{x} 0,1 \mathrm{~mm})$ & $>45$ & 47 & 33 \\
\hline
\end{tabular}

Para o CAP 40 o valor da Penetração ficou inferior ao especificado mesmo com o ligante convencional $(32 \times 0,1 \mathrm{~mm})$ e para um teor de polímero de $1,5 \%$ o valor caiu para $17 \times 0,1 \mathrm{~mm}$, ou seja, uma penetração muito baixa que poderia dificultar a trabalhabilidade da mistura confeccionada com este ligante.

Desta forma adotou-se como sendo o Teor Ötimo de polímero para os ligantes CAP 20 e CAP $40,1,5 \%$ e $1,0 \%$ de RET, em peso do asfalto, respectivamente.

\section{- Compatibilidade}

Os valores encontrados para a Compatibilidade entre o polímero RET e os ligantes CAP 20 e CAP 40 são apresentados nas Figura 4.14 e 4.15. 


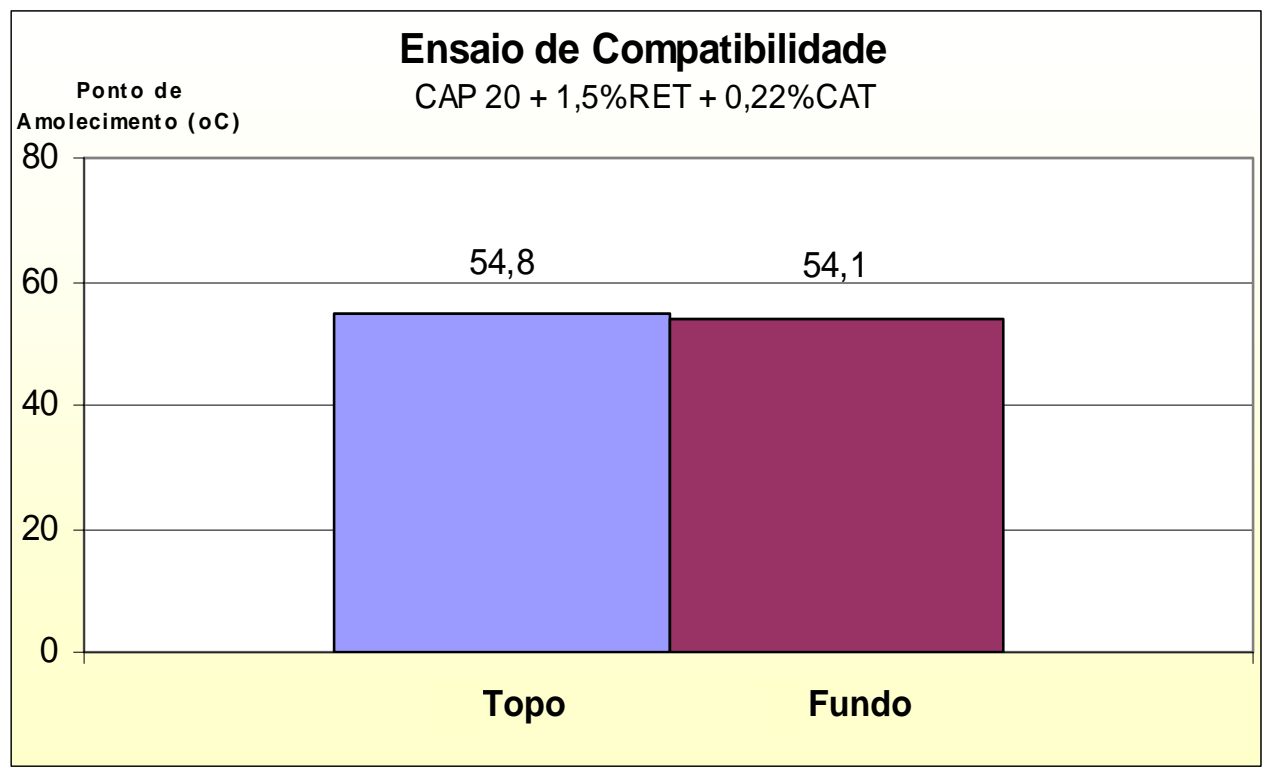

Figura 4.14 - Resultado do Ensaio de Compatibilidade entre o polímero RET e o CAP20

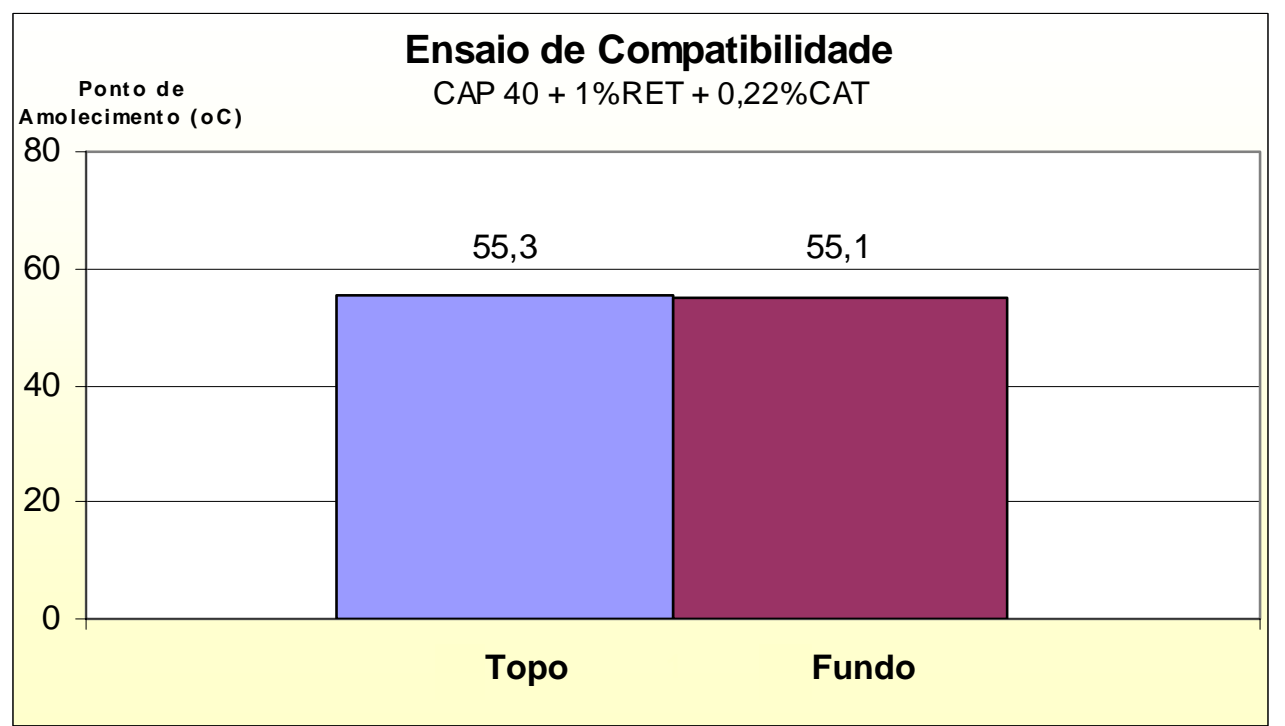

Figura 4.15 - Resultado do Ensaio de Compatibilidade entre o polímero RET e o CAP40

Segundo a especificação brasileira para asfaltos modificados por polímeros DNER EM 396/99 a diferença entre o Ponto de Amolecimento da amostra coletada no topo e no fundo não deve ser superior a $4^{\circ} \mathrm{C}$. 
Desta forma, os dois ligantes ensaiados apresentaram um comportamento excelente visto que as diferenças entre os ensaios do topo e do fundo são inferiores a $1{ }^{\circ} \mathrm{C}$.

\subsection{ESTUdO DA MisturA}

O projeto consiste na seleção e na caracterização dos agregados para confecção de misturas asfálticas e preparação das mesmas contemplando os diferentes ligantes e agregados, em conformidade com o método Marshall de dosagem, amplamente utilizado no Brasil.

Por se tratar de uma etapa posterior à de desenvolvimento, foram selecionados os teores de $1,5 \%$ de RET para o CAP20 e 1,0\% para o CAP40 para a análise.

\subsubsection{Agregados}

Os agregados utilizados nos estudos são de origem basáltica explorados pela pedreira Basalto 5 situada nas proximidades do $\mathrm{km}$ 2,3 da Rodovia SP-101 Campinas/Hortolândia-SP. Após diversos ensaios, concluiu-se que os materiais estudados são adequados para a elaboração das misturas, atendendo todos os requisitos para serem utilizados como agregados pétreos para misturas asfálticas. Os resultados dos ensaios encontram-se na tabela 4.6.

Tabela 4.6: Características do Agregado Estudado

\begin{tabular}{|l|c|c|c|}
\hline \multicolumn{1}{|c|}{ Ensaio } & Método & Obtido & Especificado \\
\hline Abrasão Los Angeles & DNER ME 035/94 & $13 \%$ & $<50 \%$ \\
\hline $\begin{array}{l}\text { Equivalente de Areia (sem cal) } \\
\begin{array}{l}\text { Durabilidade Frente ao Sulfato de } \\
\text { Sódio (Brita 1 e Pedrisco) }\end{array}\end{array}$ & DNER ME 054/94 & $56,5 \%$ & $>55 \%$ \\
\hline $\begin{array}{l}\text { Durabilidade Frente ao Sulfato de } \\
\text { Sódio (Pó de Pedra) }\end{array}$ & DNER ME 089/94 & $0,90 \%$ & $<18 \%$ \\
\hline Índice de Forma (Brita 1) & DNER ME 086/94 & $0,73 \%$ & $>0,5 \%$ \\
\hline $\begin{array}{l}\text { Índice de Plasticidade } \\
\text { Limite de Liquidez }\end{array}$ & DNER ME 082/94 & NP & $<6,0 \%$ \\
\hline
\end{tabular}




\subsubsection{Granulometria de Dosagem dos Agregados}

Após granulometrias individuais realizadas com os agregados, obteve-se uma combinação com o propósito de atender a faixa granulométrica especificada para os revestimentos asfálticos, conforme Tabela 4.7.

Tabela 4.7: Composição Granulométrica

\begin{tabular}{|c|c|c|c|c|c|c|c|c|c|}
\hline \multicolumn{2}{|c|}{ PENEIRA } & \multicolumn{2}{|c|}{ BRITA 1} & \multicolumn{2}{|c|}{ PEDRISCO } & \multicolumn{2}{|c|}{ PÓ DE PEDRA } & \multirow{2}{*}{$\begin{array}{c}\text { GRANUL. } \\
\text { OBTIDA } \\
(\%)\end{array}$} & \multirow{2}{*}{$\begin{array}{l}\text { ESPECIFICAÇ } \\
\text { ÂO }(\%) \\
\text { DERSA } \\
\text { ET- } \\
\text { P00/027FIII }\end{array}$} \\
\hline $\begin{array}{c}\text { Abertura } \\
\mathrm{mm}\end{array}$ & Poleg./N & \multicolumn{2}{|c|}{$21,0 \%$} & \multicolumn{2}{|c|}{$22,0 \%$} & \multicolumn{2}{|c|}{$57,0 \%$} & & \\
\hline 19,0 & $3 / 4 "$ & 100,0 & 21,0 & - & - & - & - & 100,0 & 100 \\
\hline 12,5 & $1 / 2 "$ & 39,3 & 8,3 & 100,0 & 22,0 & - & - & 87,3 & $80-100$ \\
\hline 9,52 & $3 / 8^{\prime \prime}$ & 4,7 & 1,0 & 98,3 & 21,6 & 100,0 & 57,0 & 79,6 & $70-90$ \\
\hline 4,80 & $\mathrm{~N}^{\mathrm{o}} 4$ & 1,1 & 0,2 & 20,5 & 4,5 & 98,4 & 56,1 & 60,8 & $50-70$ \\
\hline 2,00 & $\mathrm{~N}^{\mathrm{o}} 10$ & 1,0 & 0,2 & 0,6 & 0,1 & 70,0 & 39,9 & 40,2 & $33-48$ \\
\hline 0,42 & $\mathrm{~N}^{\circ} 40$ & 0,9 & 0,2 & 0,3 & 0,1 & 34,4 & 19,6 & 19,8 & $15-25$ \\
\hline 0,175 & $\mathrm{~N}^{\mathrm{o}} 80$ & 0,7 & 0,1 & 0,2 & 0,1 & 24,6 & 14,0 & 14,2 & $8-17$ \\
\hline 0,075 & $\mathrm{~N}^{\mathrm{o}} 200$ & 0,5 & 0,1 & 0,2 & 0,0 & 13,9 & 7,9 & 8,1 & $4-10$ \\
\hline
\end{tabular}

\subsubsection{Determinação do Teor Ótimo de Ligante Asfáltico}

Foram elaborados dois projetos de mistura baseados na especificação da DERSA ETP00/027 - FAIXA III. Os ligantes utilizados foram o CAP20+1,5\%RET+0,22\%CAT e CAP40+1\%RET+0,22\%CAT. Após a determinação dos teores ótimos, foram moldados corpos de prova com os ligantes CAP20 e CAP40, e checadas as características MARSHALL para verificação do teor para os novos ligantes. Para a determinação dos teores ótimos foram plotados os seguintes gráficos:

- Densidade Aparente Máxima x Teor de Asfalto;

- Fluência x Teor de Asfalto;

- Vazios de Ar x Teor de Asfalto;

- Resistência à Tração x Teor de Asfalto;

- Estabilidade x Teor de Asfalto;

- Relação Betume Vazios x Teor de Asfalto. 
As Figuras 4.16, 4.17, 4.18, 4.19, 4.20, e 4.21 apresentam os gráficos utilizados para a determinação do teor ótimo para o ligante do tipo CAP20+1,5\%RET+0,22\%CAT. Ressalta-se que as linhas tracejadas indicam o teor ótimo encontrado e a linhas contínuas os limites máximos e/ou mínimos da especificação da DERSA.

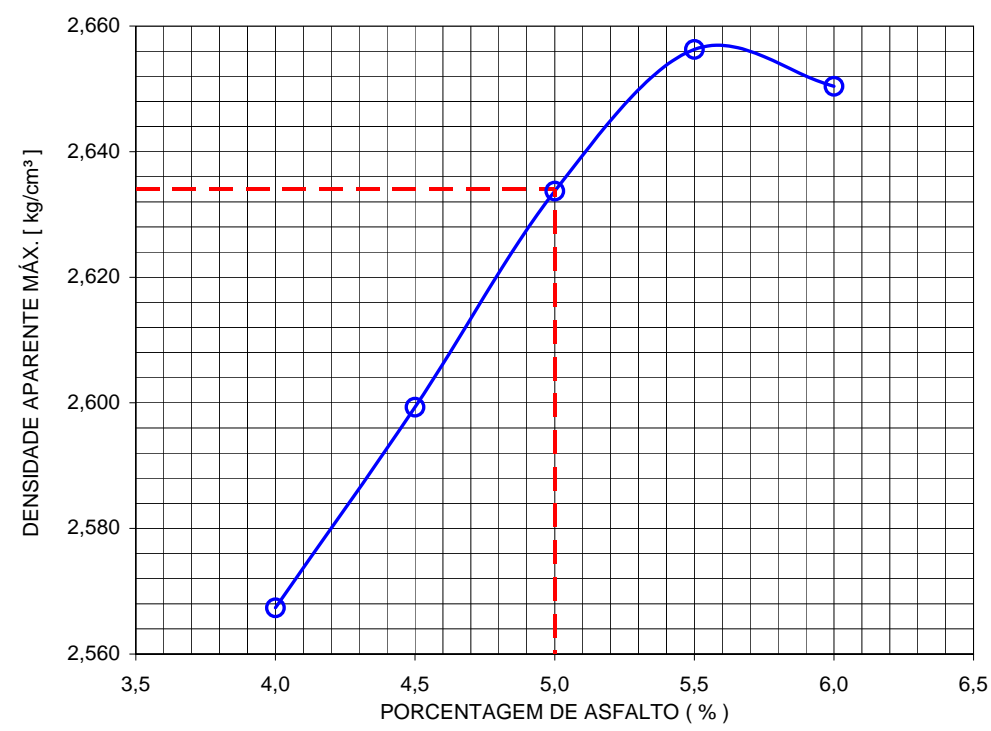

Figura 4.16 - Gráfico de Densidade Aparente Máxima x Teor do Asfalto (CAP20+1,5\%RET $+0,22 \%$ CAT)

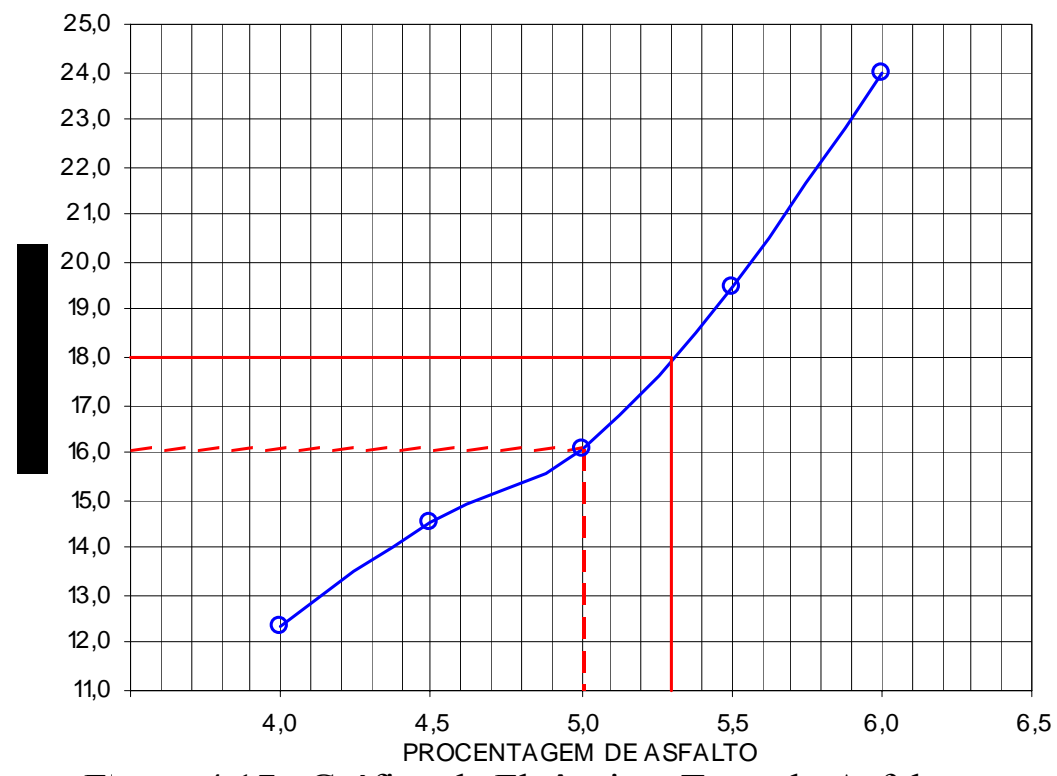

Figuı 4 4.17- Gráfico de Fluência x Teor do Asfalto (CAP20+1,5\%RET $+0,22 \%$ CAT) 


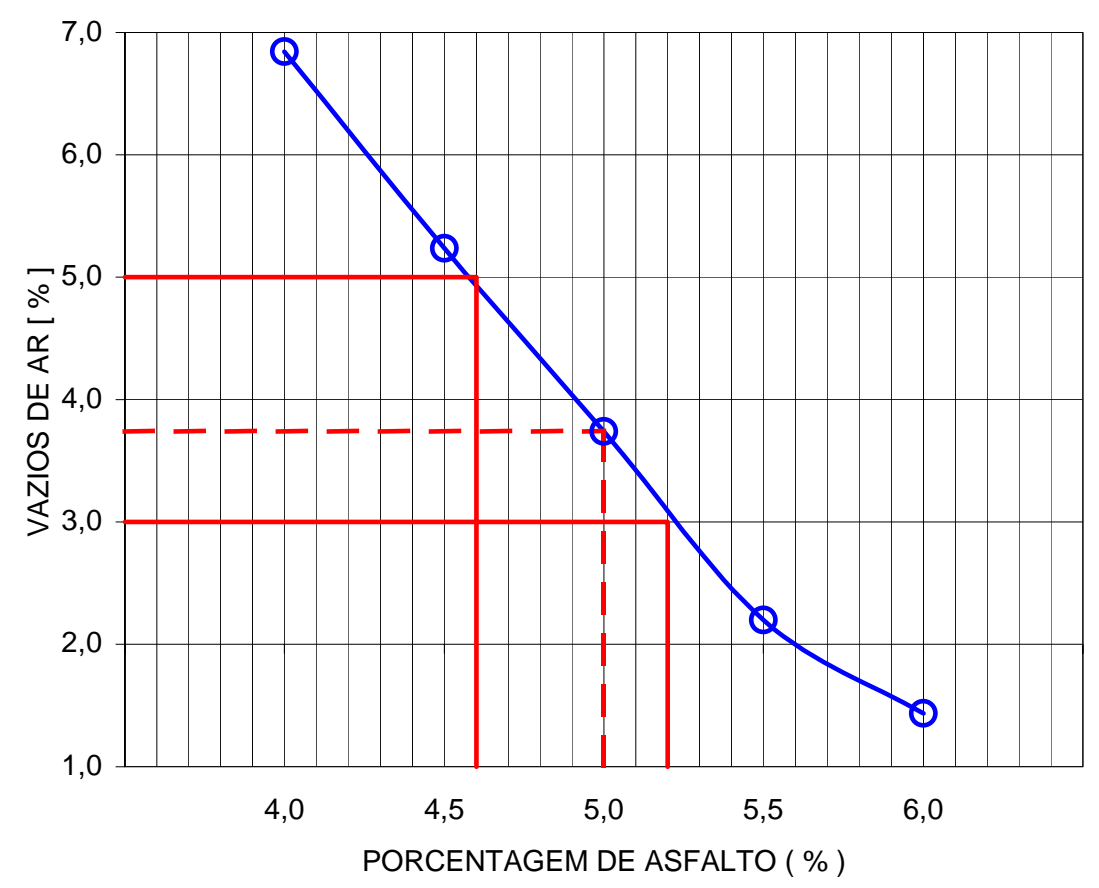

Figura 4.18 - Gráfico de Vazios de Ar x Teor do Asfalto(CAP20+1,5\%RET $+0,22 \%$ CAT)

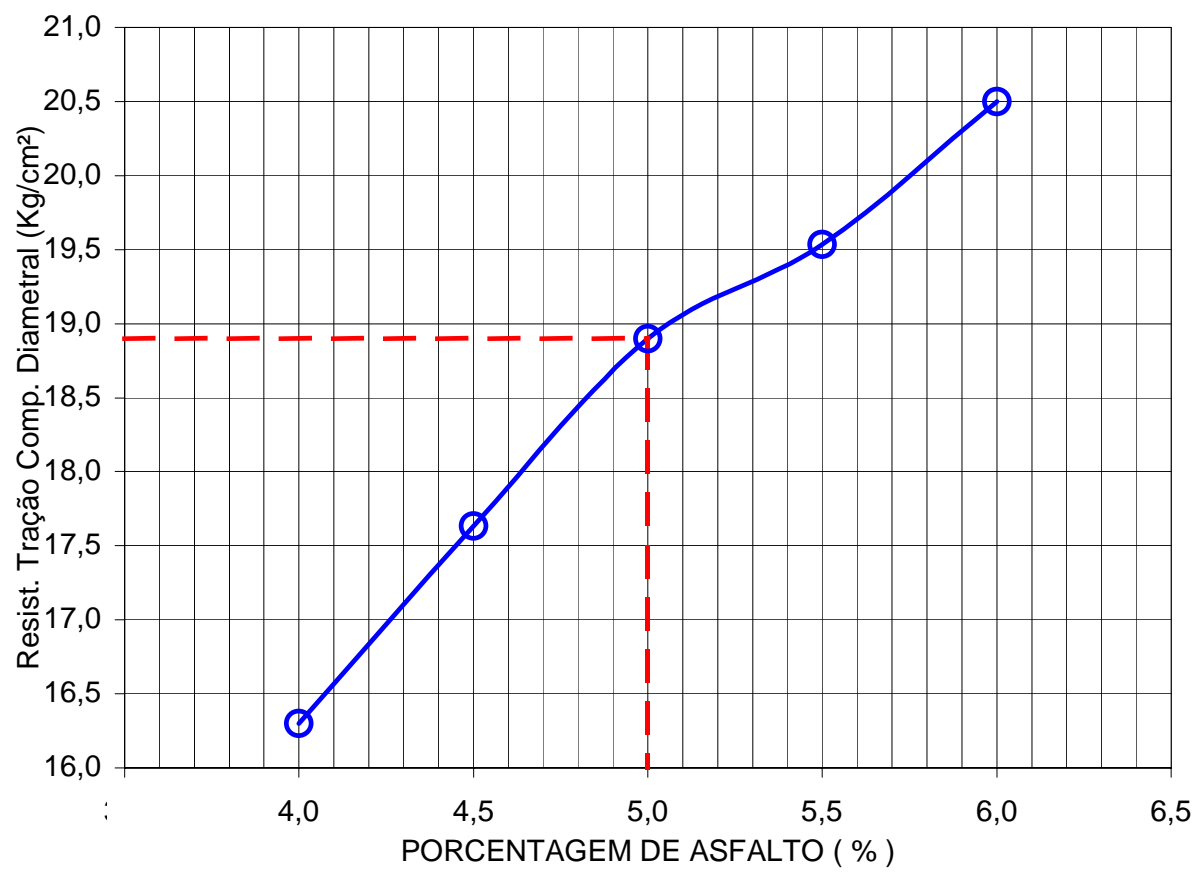

Figura 4.19 - Gráfico de Resistência à Tração x Teor do Asfalto (CAP20+1,5\%RET+0,22\%CAT) 


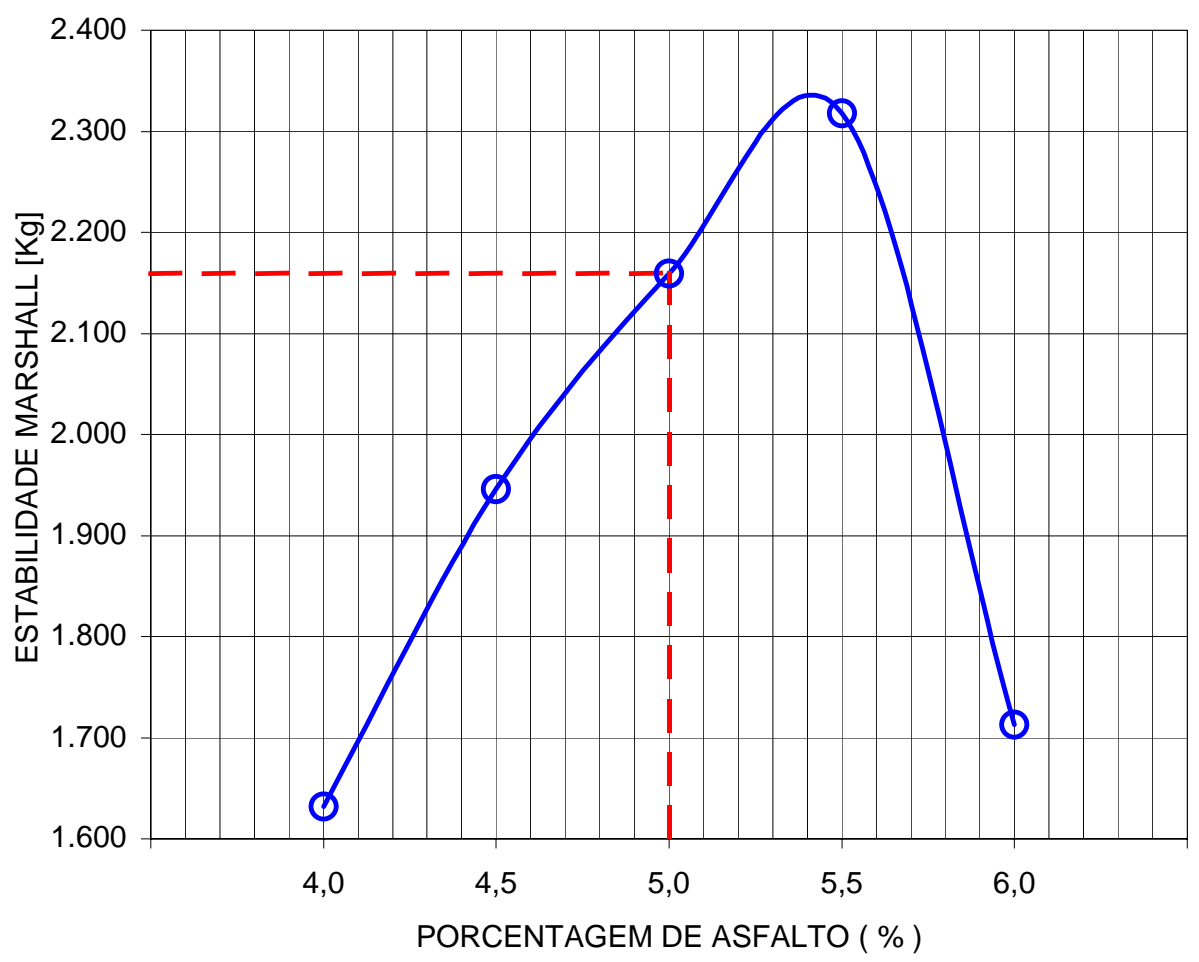

Figura 4.20 - Gráfico de Estabilidade x Teor do Asfalto (CAP20+1,5\%RET $+0,22 \%$ CAT)

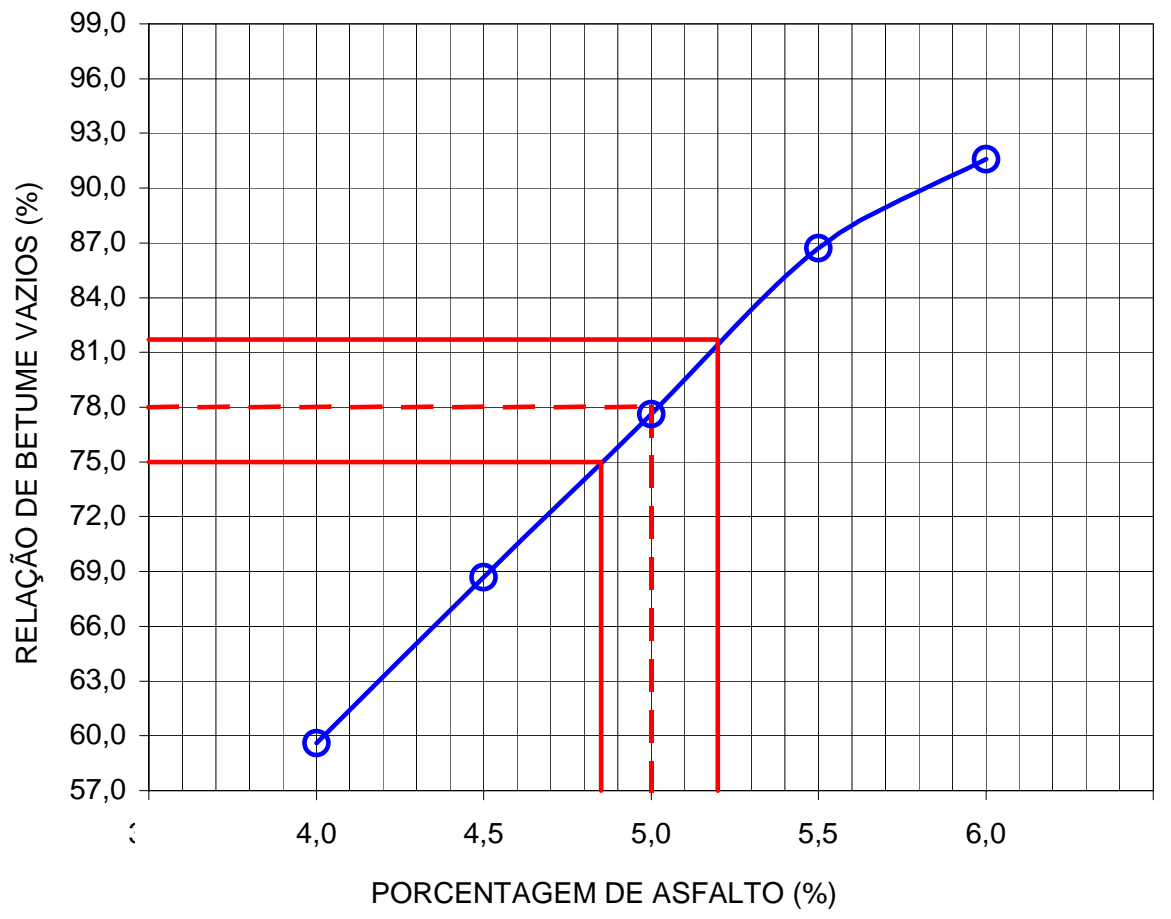

Figura 4.21 - Gráfico de Relação Betume Vazios x Teor do Asfalto (CAP20+1,5\%RET $+0,22 \%$ CAT) 
Apresenta-se na Tabela 4.8 um resumo com os valores médios encontrados para cada um dos parâmetros estudados na determinação do teor ótimo de asfalto para o ligante do tipo CAP20+1,5\%RET+0,22\%CAT, para os estudo em questão foram moldados seis corpos de prova para cada teor.

Tabela 4.8 - Resumo do Projeto de Mistura para o CAP20+1,5\%RET+0,22\%CAT

\begin{tabular}{|l|c|c|}
\hline \multicolumn{1}{|c|}{ Ensaio } & Obtido & $\begin{array}{c}\text { Especificado DERSA } \\
\text { ET-P00/027 }\end{array}$ \\
\hline Teor Ótimo & $5,0 \%$ & $4 \%$ a $6 \%$ \\
\hline Estabilidade & $2.159 \mathrm{Kg}$ & $>770$ \\
\hline Fluência & $16,2\left(1 / 100^{\prime \prime}\right)$ & $8-18(1 / 100 ")$ \\
\hline Densidade & $2,635 \mathrm{~g} / \mathrm{cm}^{3}$ & - \\
\hline Vazios de Ar & $3,7 \%$ & $3 \%-5 \%$ \\
\hline Resistência à Tração Comp. Diametral & $1,89 \mathrm{Mpa}$ & - \\
\hline Relação Betume Vazios & $78 \%$ & $75 \%-82 \%$ \\
\hline
\end{tabular}

Após a conclusão do projeto de mistura para o ligante do tipo CAP20+1,5\%RET $+0,22 \%$ CAT foram moldados oito corpos de prova no teor de ligante de 5\% (Teor ótimo de projeto para o ligante modificado) com o asfalto convencional do tipo CAP20. Constatou-se que devido à semelhança dos resultados encontrados não houve a necessidade da elaboração de um novo projeto de mistura e adotou-se o mesmo teor de asfalto como sendo o teor ótimo para ambos os casos. A Tabela 4.9 apresenta os valores médios encontrados.

Tabela 4.9 - Comparativo dos Resultados (CAP20+1,5\%RET+0,22\%CATxCAP20)

\begin{tabular}{|l|c|c|}
\hline \multicolumn{1}{|c|}{ Ensaio } & $\begin{array}{c}\text { CAP20+1,5\%RET } \\
+\mathbf{0 , 2 2 \% C A T}\end{array}$ & CAP20 \\
\hline Estabilidade & $2.159 \mathrm{Kg}$ & $1.659 \mathrm{~kg}$ \\
\hline Fluência & $16,2\left(1 / 100^{\prime \prime}\right)$ & $15,7(1 / 100 ")$ \\
Densidade & $2,635 \mathrm{~g} / \mathrm{cm}^{3}$ & $2,646 \mathrm{~g} / \mathrm{cm}^{3}$ \\
Vazios de Ar & $3,7 \%$ & $3,81 \%$ \\
\hline Resistência à Tração Comp. Diametral & $1,89 \mathrm{Mpa}$ & $2,02 \mathrm{Mpa}$ \\
\hline Relação Betume Vazios & $78 \%$ & $77,4 \%$ \\
\hline
\end{tabular}


As Figuras 4.22, 4.23, 4.24, 4.25, 4.26 e 4.27 apresentam os gráficos utilizados para a determinação do teor ótimo para o ligante do tipo CAP40+1\%RET+0,22\%CAT. Ressalta-se que as linhas tracejadas indicam o teor ótimo encontrado e a linhas contínuas os limites máximos e/ou mínimos da especificação da DERSA ETP00/027 - FAIXA III.

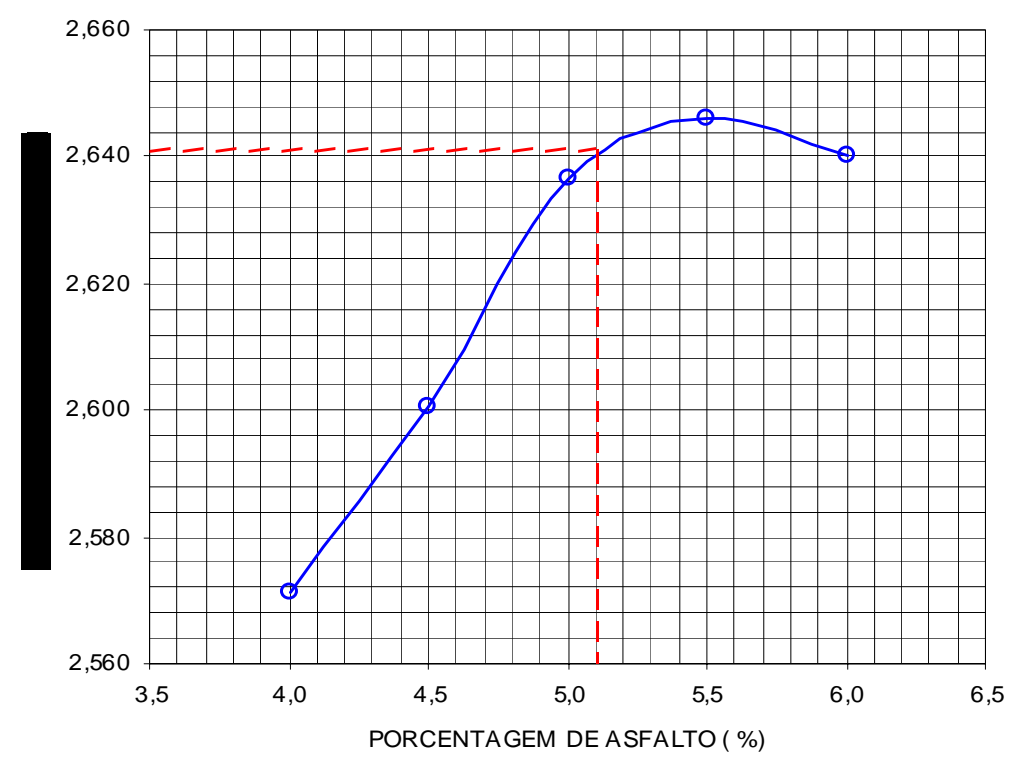

Figura 4.22 - Gráfico de Densidade Aparente Máxima x Teor do Asfalto $(\mathrm{CAP} 40+1 \% \mathrm{RET}+0,22 \% \mathrm{CAT})$

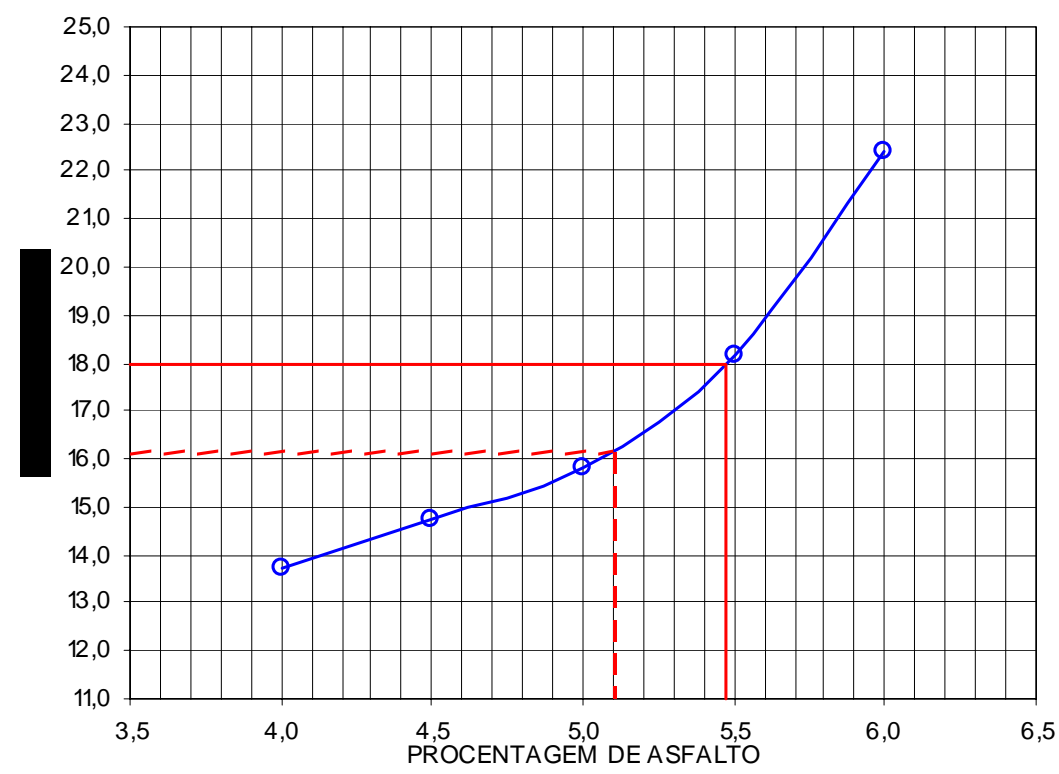

Figura 4.23 - Gráfico de Fluência x Teor do Asfalto (CAP40+1\%RET+0,22\%CAT) 


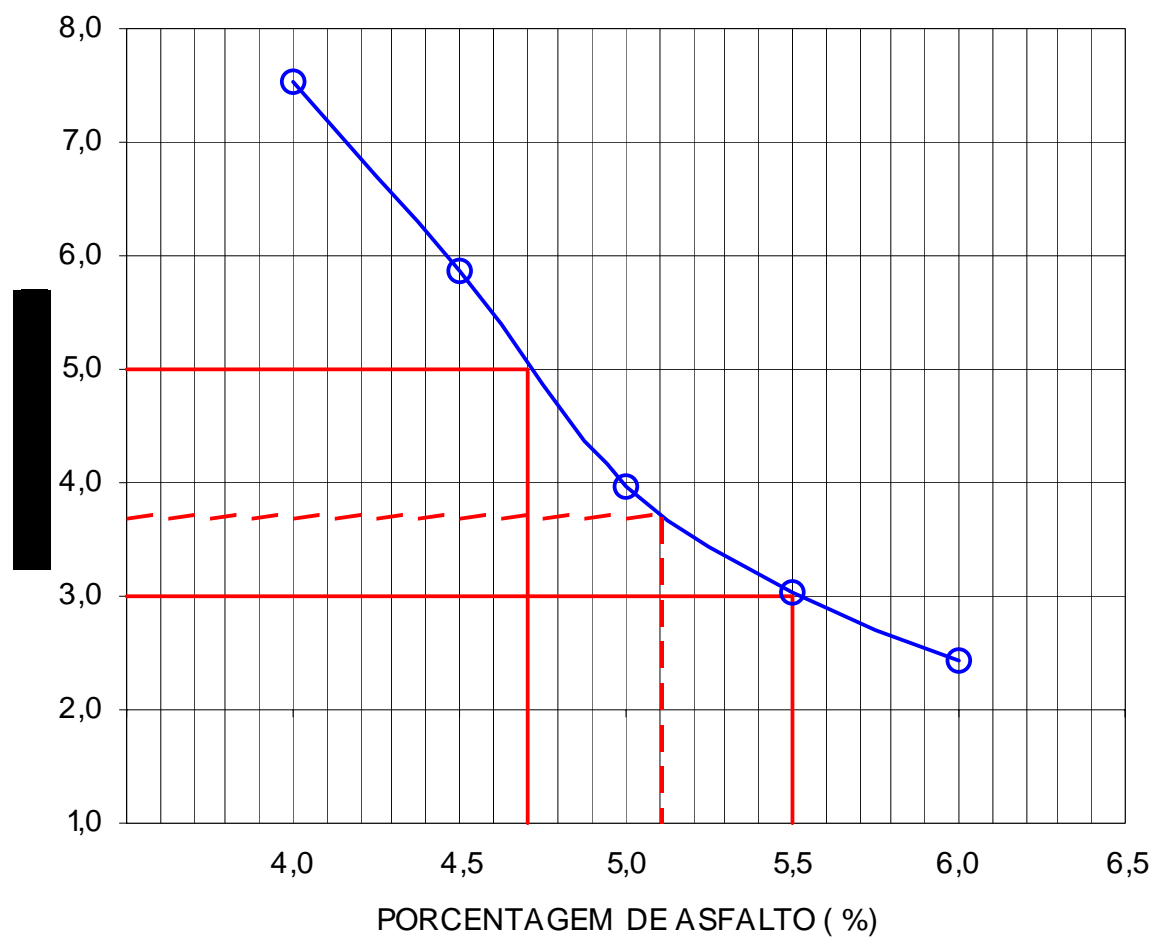

Figura 4.24 - Gráfico de Vazio de Ar x Teor do Asfalto (CAP40+1\%RET+0,22\%CAT)

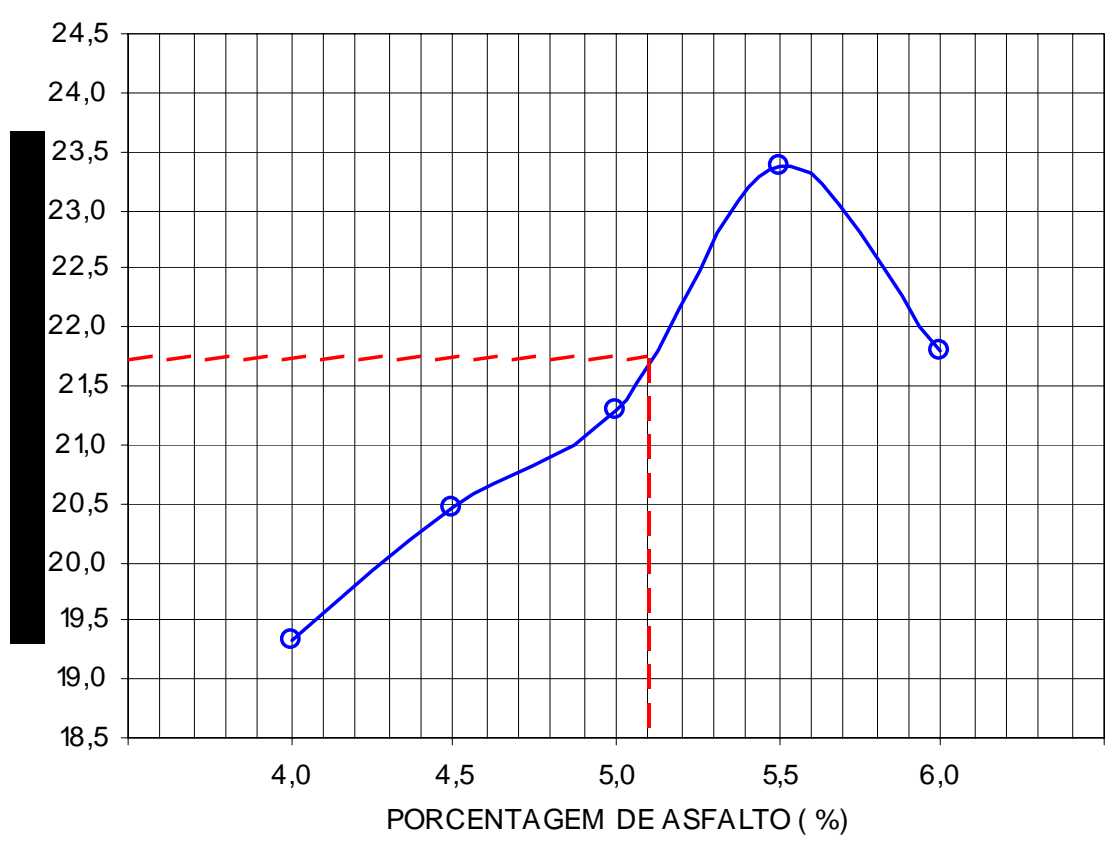

Figura 4.25 - Gráfico de Resistência à Tração x Teor do Asfalto (CAP40+1\%RET+0,22\%CAT) 


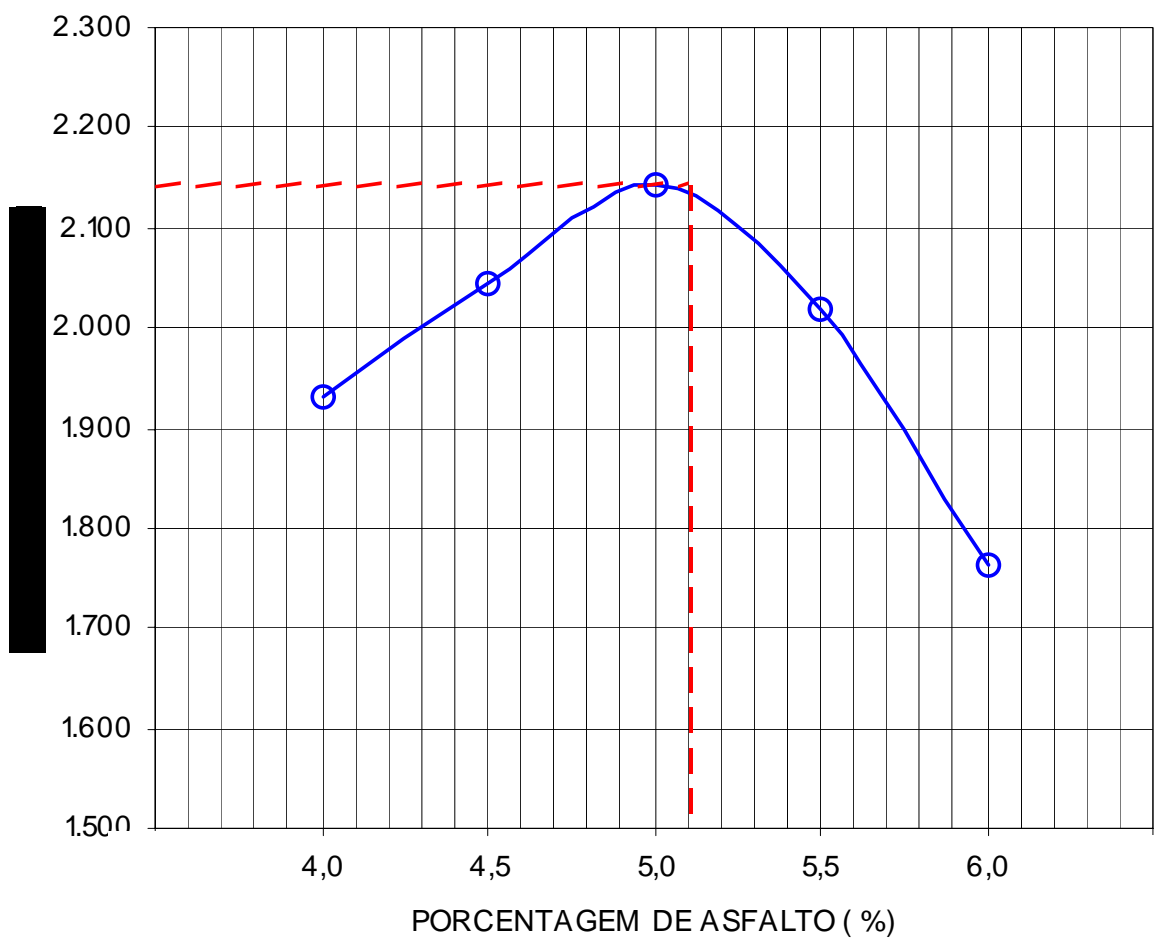

Figura 4.26 - Gráfico de Estabilidade x Teor do Asfalto (CAP40+1\%RET+0,22\%CAT)

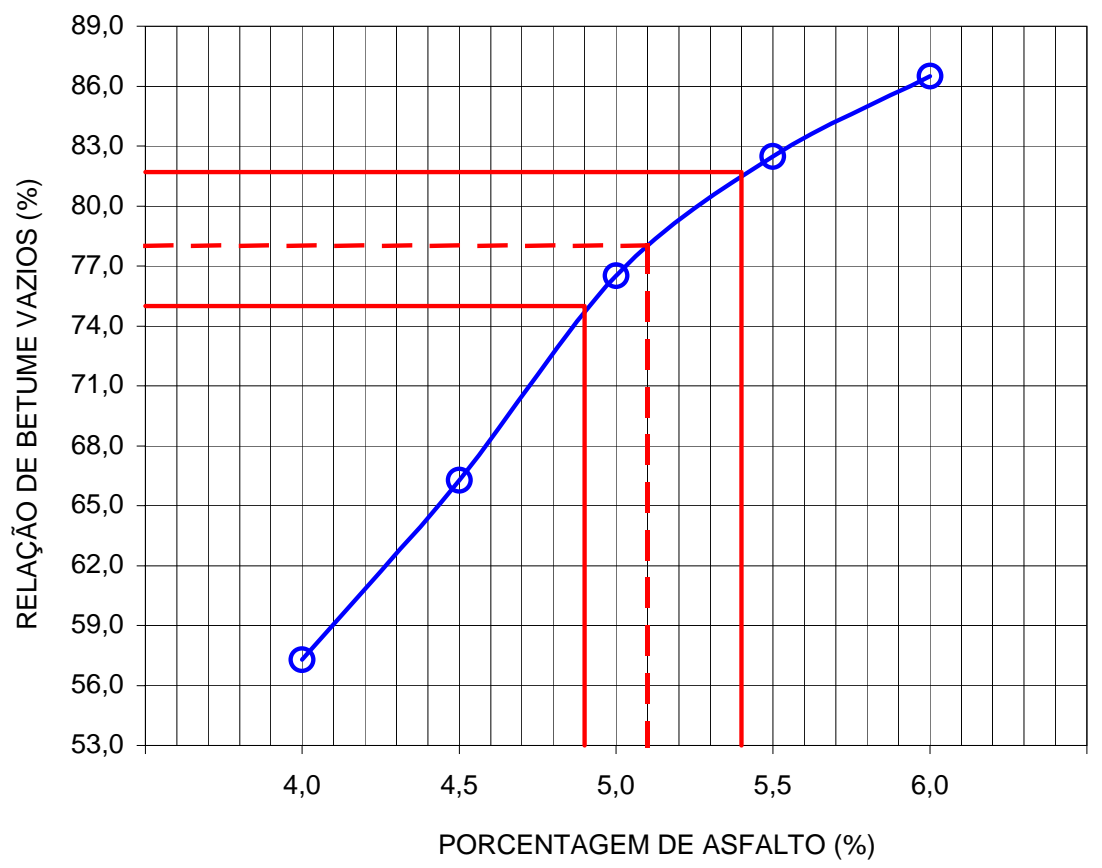

Figura 4.27 - Gráfico de Relação Betume Vazios x Teor do Asfalto (CAP40+10\%RET $+0,22 \%$ CAT) 
Apresenta-se na Tabela 4.10 um resumo com os valores médios encontrados para cada um dos parâmetros estudados na determinação do teor ótimo de asfalto para o ligante do tipo CAP40+1\%RET $+0,22 \% \mathrm{CAT}$, para o estudo em questão foram moldados seis corpos de prova para cada um dos teores.

Tabela 4.10 - Resumo do Projeto de Mistura para o CAP40+1\%RET+0,22\%CAT

\begin{tabular}{|l|c|c|}
\hline \multicolumn{1}{|c|}{ Ensaio } & Obtido & $\begin{array}{c}\text { Especificado DERSA } \\
\text { ET-P00/027 }\end{array}$ \\
\hline Teor Ótimo & $5,1 \%$ & $4 \%$ a $6 \%$ \\
\hline Estabilidade & $2.140 \mathrm{Kg}$ & $>770$ \\
\hline Fluência & $16,3\left(1 / 100^{\prime \prime}\right)$ & $8-18(1 / 100 ")$ \\
\hline Densidade & $2,642 \mathrm{~g} / \mathrm{cm}^{3}$ & - \\
\hline Vazios de Ar & $3,8 \%$ & $3 \%-5 \%$ \\
\hline Resistência à Tração Comp. Diametral & $2,18 \mathrm{MPa}$ & - \\
\hline Relação Betume Vazios & $78 \%$ & $75 \%-82 \%$ \\
\hline
\end{tabular}

Como com o CAP 20, procedeu-se após a conclusão do projeto de mistura para o ligante do tipo CAP40+1\%RET $+0,22 \% \mathrm{CAT}$, a moldagem de oito corpos-de-prova no teor de ligante de 5,1\% (Teor ótimo de projeto para o ligante modificado) com o asfalto convencional do tipo CAP40. Constatou-se que devido à semelhança dos resultados encontrados não houve a necessidade da elaboração de um novo projeto de mistura e adotou-se o mesmo teor de asfalto como sendo o teor ótimo para ambos os casos. A Tabela 4.11 apresenta os valores médios encontrados.

Tabela 4.11 - Comparativo dos Resultados (CAP40+1\%RET +0,22\%CATxCAP40)

\begin{tabular}{|l|c|c|}
\hline \multicolumn{1}{|c|}{ Ensaio } & $\begin{array}{c}\text { CAP40+1\%RET } \\
+\mathbf{0 , 2 2 \% C A T}\end{array}$ & CAP40 \\
\hline Estabilidade & $2.140 \mathrm{Kg}$ & $1.530 \mathrm{~kg}$ \\
\hline Fluência & $16,3\left(1 / 100^{\prime \prime}\right)$ & $13,6(1 / 100 ")$ \\
Densidade & $2,642 \mathrm{~g} / \mathrm{cm}^{3}$ & $2,642 \mathrm{~g} / \mathrm{cm}^{3}$ \\
\hline Vazios de Ar & $3,8 \%$ & $3,96 \%$ \\
\hline Resistência à Tração Comp. Diametral & $2,18 \mathrm{Mpa}$ & $2,30 \mathrm{MPa}$ \\
\hline Relação Betume Vazios & $78 \%$ & $76,6 \%$ \\
\hline
\end{tabular}




\subsubsection{Temperaturas de Usinagem e Compactação}

As temperaturas de usinagem e compactação foram determinadas em função da relação viscosidade $\mathrm{x}$ temperatura. A Tabela 4.12 apresenta um resumo com os valores obtidos.

Tabela 4.12 - Temperaturas de usinagem e compactação

\begin{tabular}{|l|c|c|c|}
\hline \multicolumn{1}{|c|}{ Tipo de Ligante } & \multicolumn{2}{|c|}{$\begin{array}{c}\text { Faixa de Temperatura de } \\
\text { Trabalho }\left({ }^{\circ} \mathrm{C}\right)\end{array}$} & $\begin{array}{c}\text { Densidade da Mistura } \\
\left(\mathrm{g} / \mathrm{cm}^{3}\right)\end{array}$ \\
\hline CAP20 & 151,2 a 157,0 & 139,0 a 144,3 & 2,635 \\
\hline CAP20+1,5\%RET+0,22\%CAT & 168,8 a 173,8 & 168,5 a 163,1 & 2,646 \\
\hline CAP40 & 153,1 a 158,6 & 141,5 a 146,6 & 2,642 \\
\hline CAP40+1\%RET+0,22\%CAT & 166,1 a 171,3 & 155,2 a 160,0 & 2,642 \\
\hline
\end{tabular}

\subsubsection{Desempenho das Misturas Asfálticas}

As misturas asfálticas selecionadas foram submetidas a ensaios de carga repetida em laboratório para determinação das suas propriedades mecânicas e de deformabilidade, objetivando a avaliação das seguintes características:

- $\mathrm{M}_{\mathrm{R}}$ : Módulo de Resiliência das misturas obtido através de ensaio de compressão diametral de cargas repetidas, de acordo com a norma técnica DNER-ME 133/94;

- Rt: Resistência à Tração estática nos ensaios de compressão diametral, em conformidade com a norma ABNT 15087/2004;

- $\mathrm{E}_{\mathrm{p}}$ : deformação permanente avaliada em simulador de tráfego do tipo LPC conforme a especificação francesa NF P 98-253-1 "Déformation Permanente des Mélanges Hydrocarbonés". 


\subsubsection{Módulo de Resiliência $\left(M_{R}\right)$}

Na Tabela 4.13 estão apresentados os resultados médios dos ensaios de Módulo de Resiliência, neste estudo foram ensaiados três corpos de prova para cada tipo de ligante estudado.

Tabela 4.13 - Resultados Médios dos Ensaios de Módulo de Resiliência encontrados

\begin{tabular}{|l|c|}
\multicolumn{1}{c|}{ Ligante } & $\begin{array}{c}\text { Mr } \\
\text { (MPa) }\end{array}$ \\
\hline CAP 20 & 5.961 \\
\hline CAP20+1,5\%RET+0,22\%CAT & 5.900 \\
\hline CAP 40 & 7.672 \\
\hline CAP40+1\%RET $+0,22 \%$ CAT & 7.419 \\
\hline
\end{tabular}

Observa-se que os valores de Módulo de Resiliência encontrados para os corpos de prova confeccionados com asfalto convencional são muito próximos daqueles que utilizaram os asfaltos convencionais, isto sugere que o polímero do tipo RET não altera o comportamento da mistura asfáltica em termos de Módulo de Resiliência.

\subsubsection{Resistência à Tração por Compressão Diametral}

Na Tabela 4.14 abaixo estão apresentados os resultados dos ensaios de Resistência à Tração por Compressão Diametral, neste estudo foram ensaiados três corpos de prova para cada tipo de ligante estudado.

Tabela 4.14 - Resultados Médios dos Ensaios de Resistência à Tração

\begin{tabular}{|l|c|c|}
\hline \multicolumn{2}{|c|}{ Resistência à Tração por Compressão Diametral (MPa) } \\
\hline \multirow{2}{*}{ Ligante } & \multicolumn{2}{|c|}{ Temperatura $\left({ }^{\circ} \mathbf{C}\right)$} \\
\cline { 2 - 3 } & $\mathbf{2 5}$ & $\mathbf{3 5}$ \\
\hline CAP 20 & 1,23 & 0,90 \\
\hline CAP20+1,5\%RET+0,22\%CAT & 1,58 & 1,15 \\
CAP 40 & 1,90 & 1,28 \\
\hline CAP40+1\%RET+0,22\%CAT & 1,88 & 1,29 \\
\hline
\end{tabular}


Observa-se que para o CAP20 houve um incremento de quase 30\% no valor da Resistência à Tração à $25^{\circ} \mathrm{C}$ com o valor passando de 1,23 no asfalto convencional para 1,58 no modificado. Para o CAP40, a Resistência à Tração não foi sensível à modificação e os valores permaneceram praticamente inalterados.

\subsubsection{Deformação Permanente}

O ensaio de deformação permanente foi realizado com os quatro tipos de misturas pré-selecionadas. Foi ensaiada uma placa para cada ligante sendo seguida a especificação francesa NF P 98-253-1 “Déformation Permanente des Mélanges Hydrocarbonés". Os resultados encontram-se sintetizados na Tabela 4.15 e Figuras 4.28 e 4.29 , sendo os gráficos representados na forma sugerida pela norma.

Tabela 4.15 - Resultados do Ensaio de Deformação Permanente em Simulador LPC

\begin{tabular}{|l|c|}
\hline \multicolumn{1}{|c|}{ Tipo de Ligante Asfáltico } & Afundamentos (\%) \\
\hline CAP 20 & 7,44 \\
\hline CAP $20+1,5 \%$ RET $+0,22 \%$ CAT & 3,82 \\
CAP 40 & 6,17 \\
\hline CAP $40+1,0 \%$ RET $+0,22 \%$ CAT & 3,88 \\
\hline
\end{tabular}

Neste estudo foi ensaiada uma placa para cada tipo de ligante estudado. 


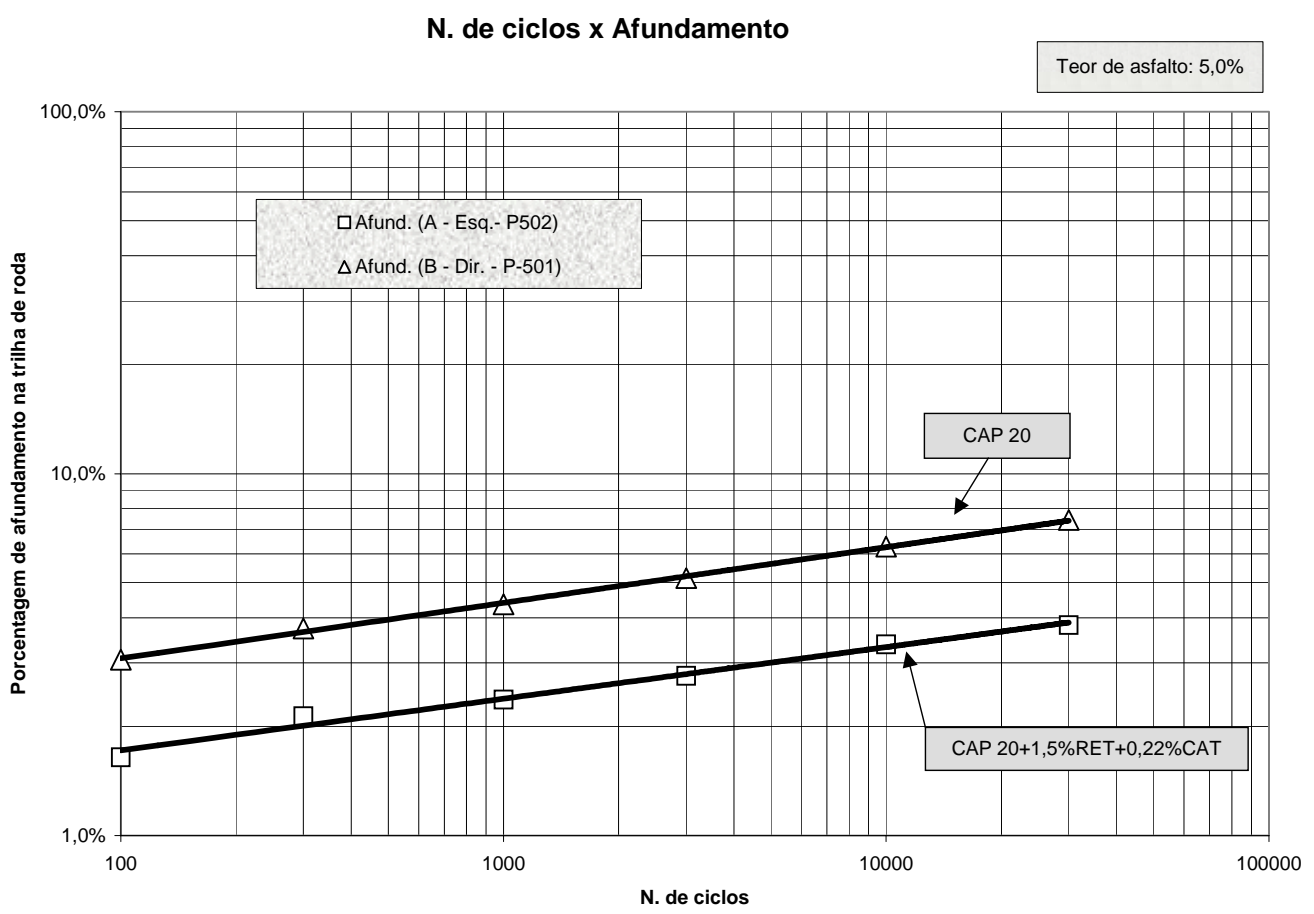

Figura 4.28 - Ensaio de Deformação Permanente em Simulador do tipo LPC (CAP20/CAP20+1,5\%RET+0,22\%RET)

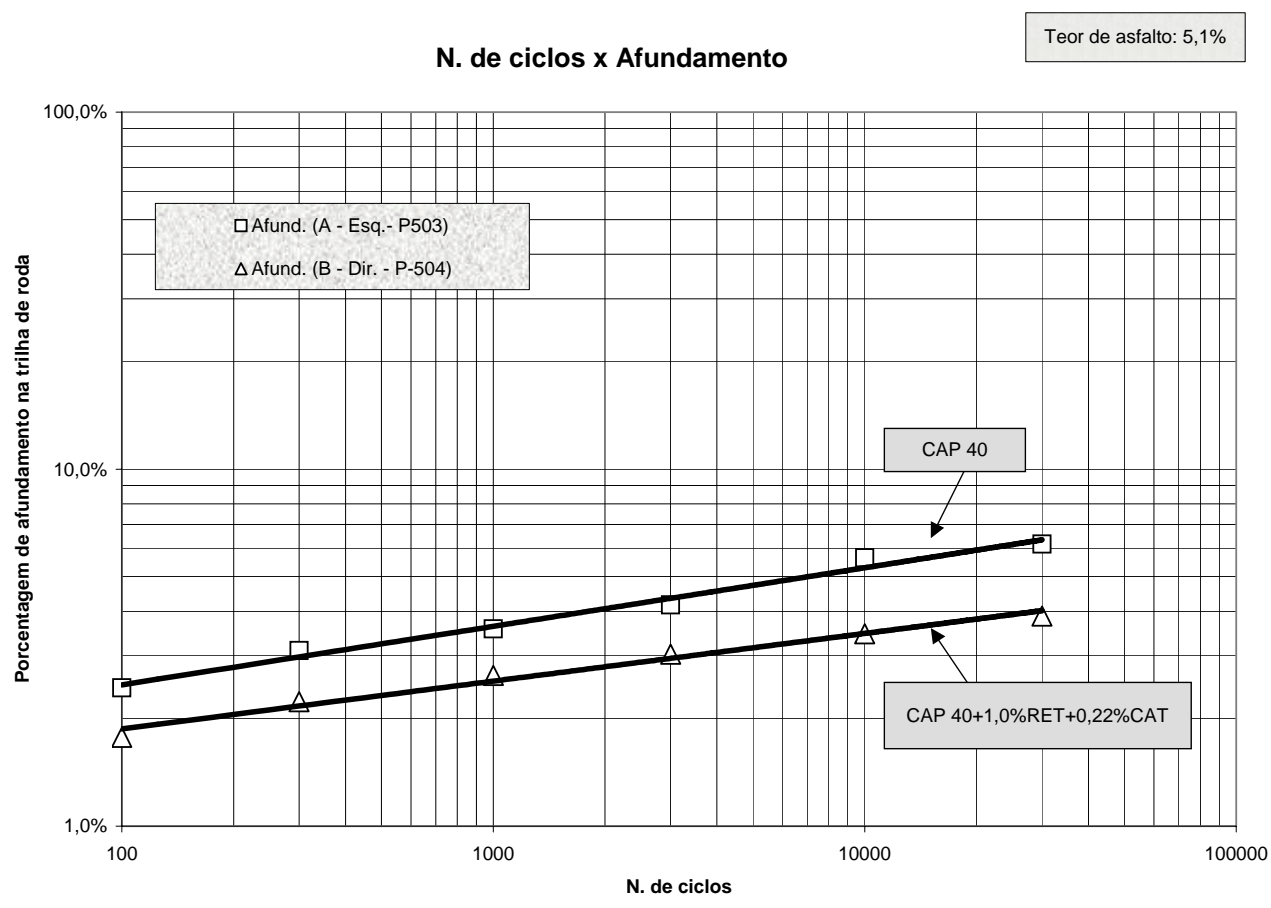

Figura 4.29 - Ensaio de Deformação Permanente em Simulador do tipo LPC (CAP40/CAP40+1\%RET+0,22\%RET) 
As Figuras 4.30, 4.31, 4.32 e 4.33 mostram as placas após 30.000 ciclos de ensaio no simulador de tráfego tipo LPC.

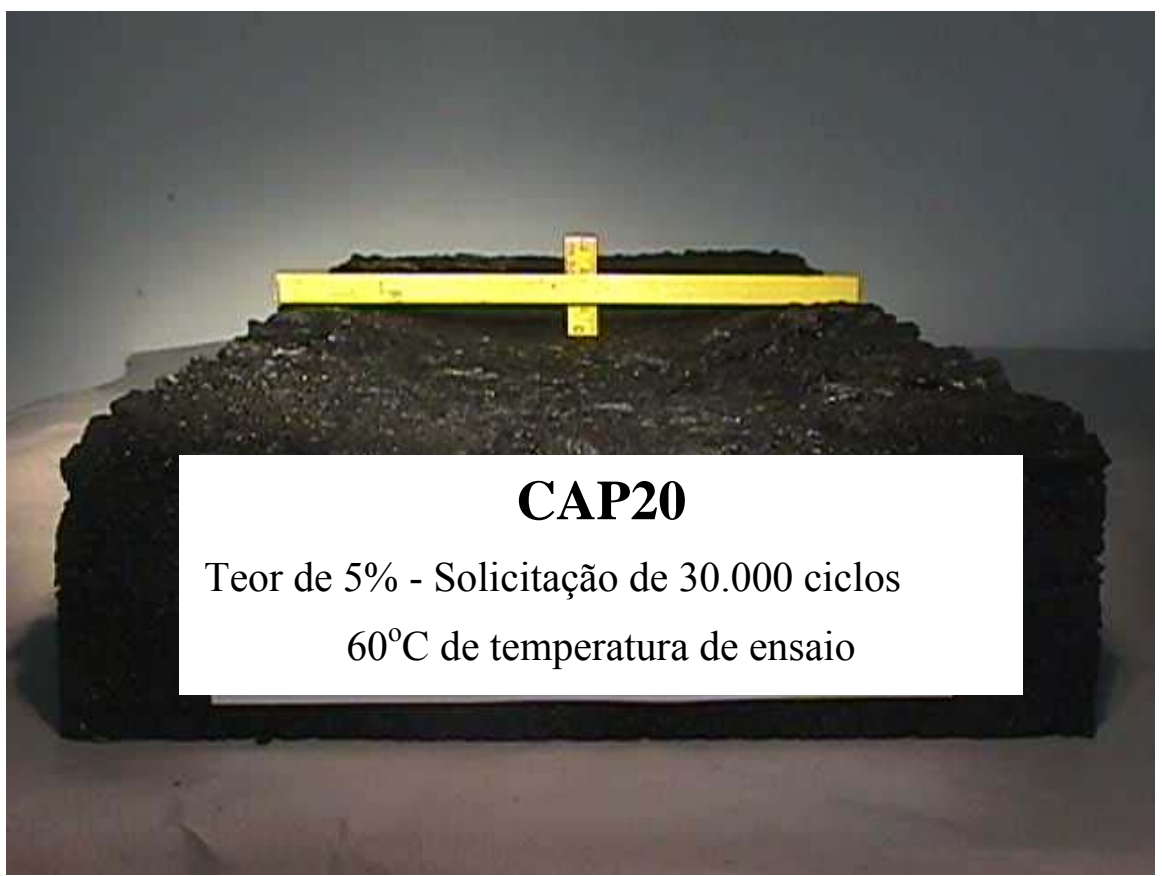

Figura 4.30 - Placa ensaiada após 30.000 ciclos a $60^{\circ} \mathrm{C}$ - CAP20

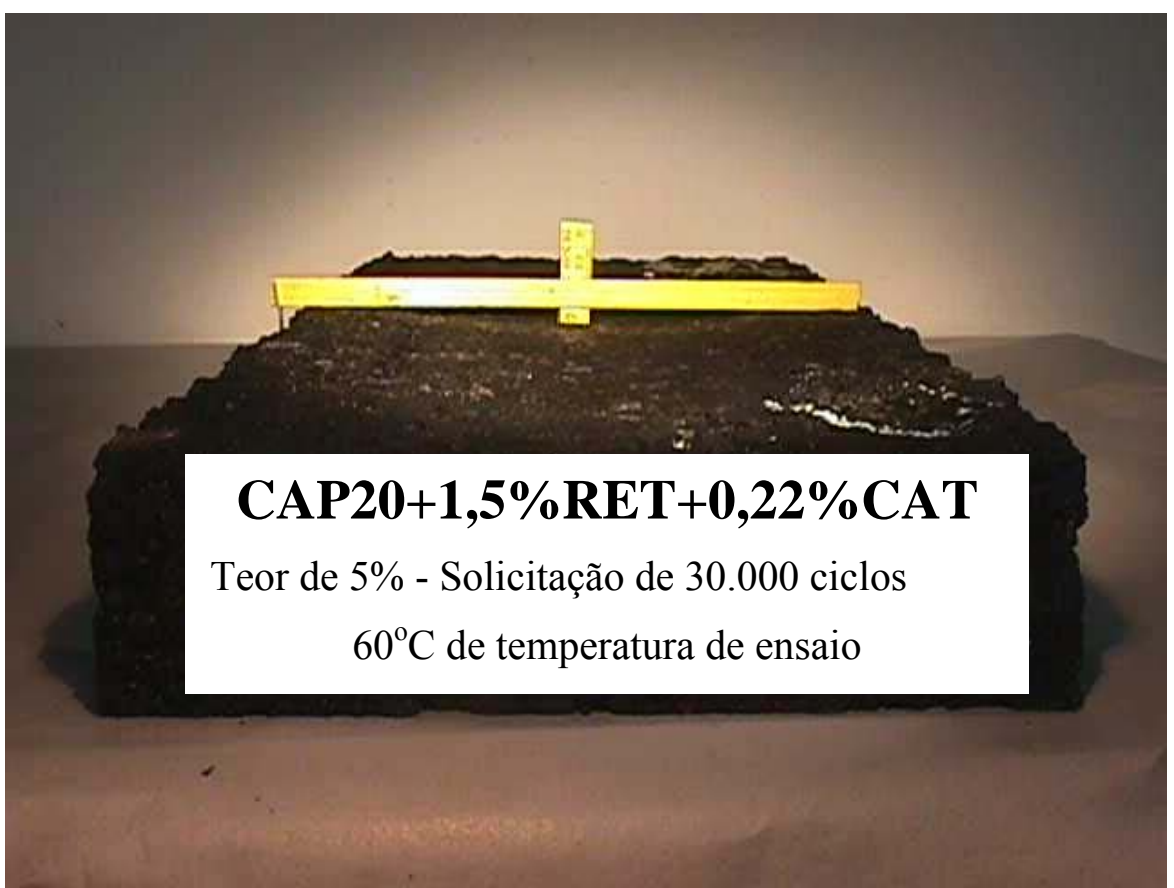

Figura 4.31 - Placa ensaiada após 30.000 ciclos a $60^{\circ} \mathrm{C}-$ CAP $20+1,5 \%$ RET $+0,22 \%$ CAT 


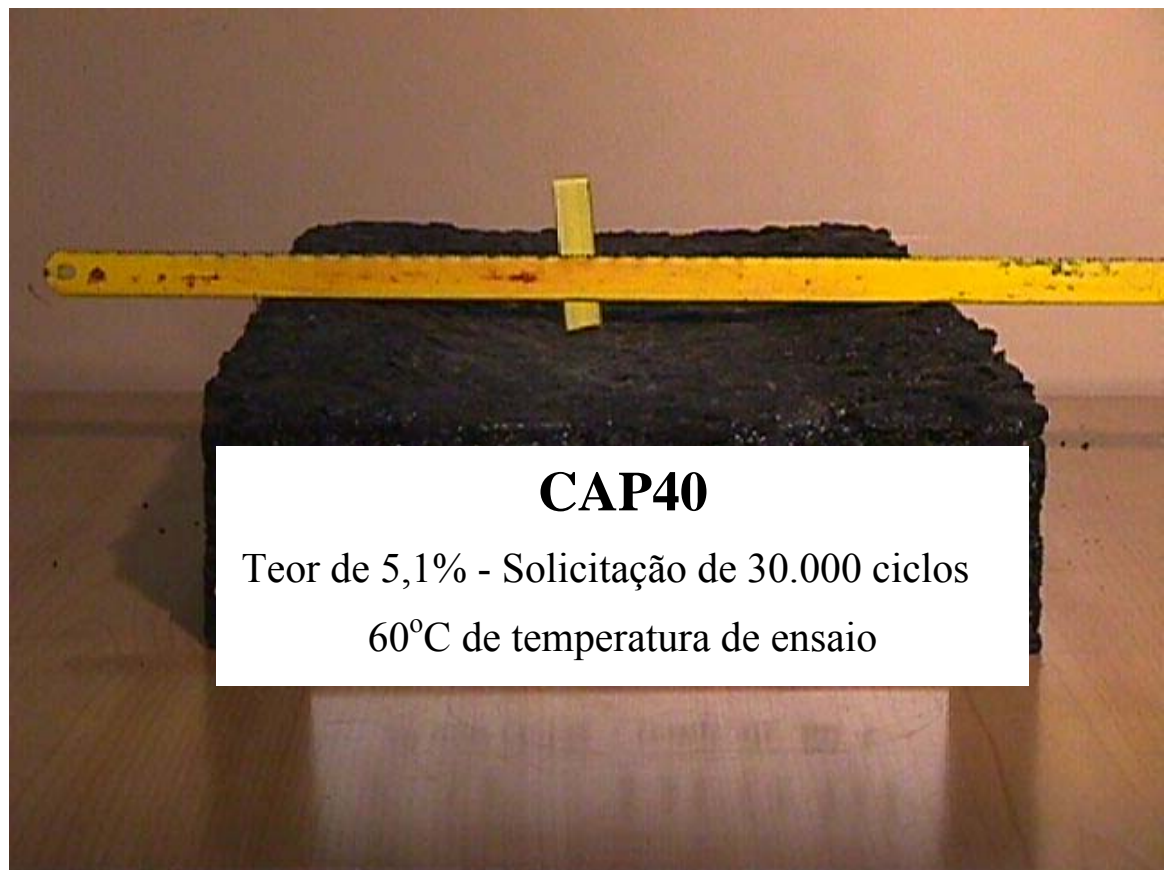

Figura 4.32 - Placa ensaiada após 30.000 ciclos a $60^{\circ} \mathrm{C}-\mathrm{CAP} 40$

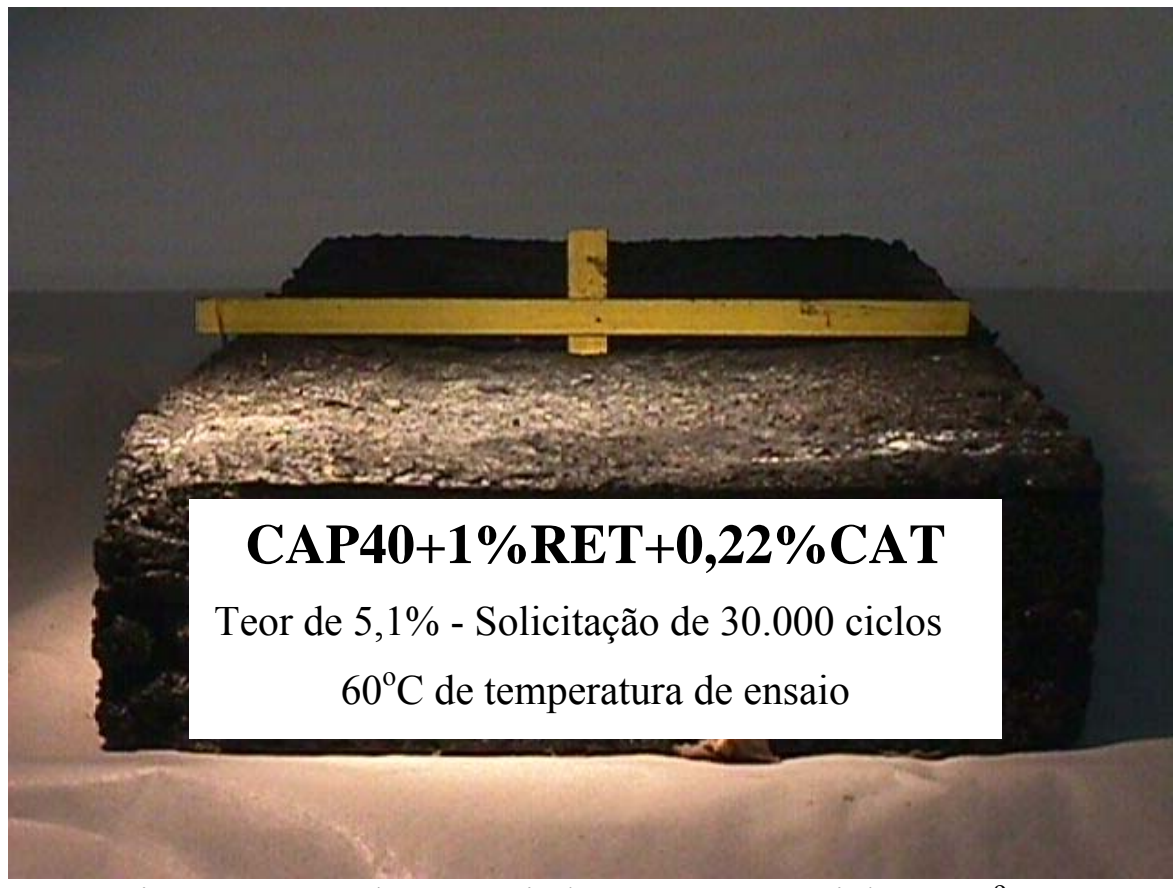

Figura 4.33 - Placa ensaiada após 30.000 ciclos a $60^{\circ} \mathrm{C}-$ CAP $40+1 \%$ RET $+0,22 \%$ CAT

De acordo com a especificação francesa NF P 98-253-1, para elevado volume de tráfego, é requerida deformação permanente inferior a 5\% após 30.000 ciclos no simulador tipo LPC a $60^{\circ} \mathrm{C}$, com a carga e pressão de pneu conforme especificado em norma. Esta especificação é a aconselhada também para camadas asfálticas de módulo elevado. 
Neste aspecto, observa-se que somente as misturas asfálticas modificadas apresentaram valores abaixo do limite máximo permitido, com resultados muito similares e inferiores a $4 \%$. 


\section{ESTUDO DE CASO: TRECHO EXPERIMENTAL DA VIA ANHANGUERA}

O trecho experimental de restauração dos pavimentos empregando-se o ligante modificado por polímero do tipo RET foi executado em março de 2002 entre os quilômetros 79+500 e 81+500 da Pista Norte (sentido São Paulo-Campinas) da Rodovia Anhanguera (SP-330), no estado de São Paulo. A localização da via Anhanguera encontra-se ilustrada na Figura 5.1.

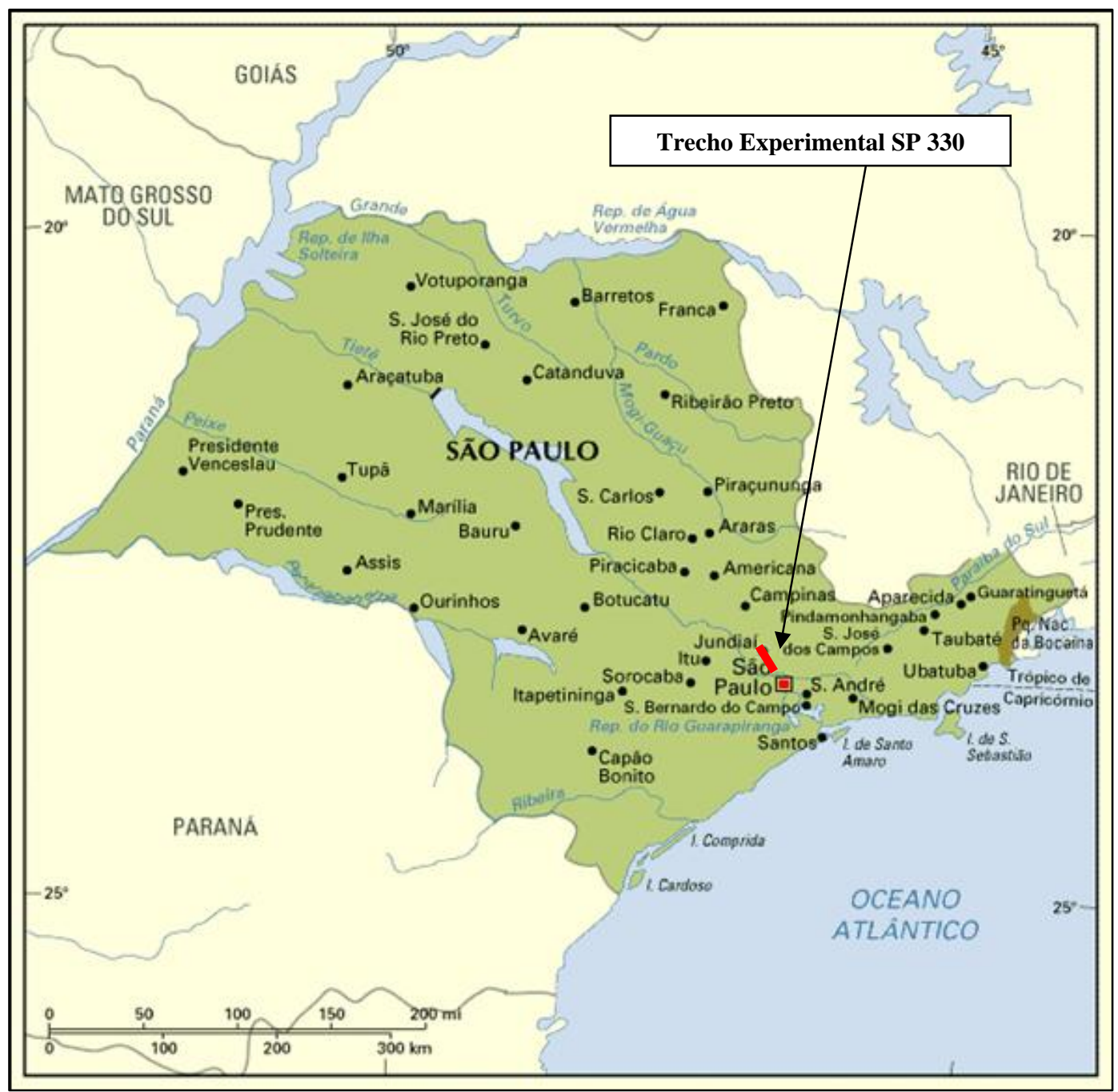

Figura 5.1 - Ilustração da localização da via SP-330, local onde foi executado o trecho experimental 
A seleção do segmento para a execução do trecho experimental com asfalto modificado por polímero do tipo RET na rodovia Anhanguera teve como princípio o atendimento à condição típica de aplicação deste tipo de material: segmentos com deficiência estrutural, que necessitam da aplicação de reforço para adequar os níveis deflectométricos ao tráfego solicitante e alta durabilidade para evitar manutenção prematura. Trata-se de rodovia com grande volume de tráfego pesado neste trecho.

\subsection{CONDIÇÕES ORIGINAIS DO SEGMENTO}

Através dos dados extraídos do projeto de restauração do segmento em questão podese conhecer as condições de geometria, ter-se uma idéia do histórico e da estrutura deste pavimento, verificar a condição do pavimento previamente à sua recuperação e o nível de tráfego solicitante.

\subsubsection{Geometria Histórico e Estrutura}

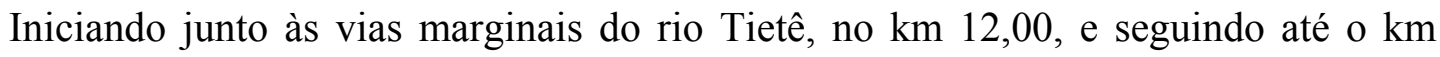
102,440, a Rodovia Anhanguera (SP-330) apresenta seção transversal típica constituída de duas pistas com duas faixas de tráfego por sentido, cada uma com 3,60 $\mathrm{m}$ de largura em média. Já o acostamento e a faixa de segurança apresentam dimensões variáveis.

A rodovia dispõe de canteiro central variável e atravessa uma região cuja topografia pode ser considerada ondulada. Assim, em pontos distintos ao longo do trecho, são presentes terceiras faixas de extensão variáveis, normalmente localizadas nos aclives mais íngremes.

A Rodovia Anhanguera foi duplicada na década de 60 e sofreu, ao longo destes anos, diversas intervenções de conservação e restauração, o que torna a estrutura de seus pavimentos complexa e heterogênea. 
A partir de investigações geotécnicas e estudos anteriormente realizados pela concessionária Autoban, foi obtida a seção para o segmento do km 79,5 ao km 81,5, representado na Figura 5.2.:

\begin{tabular}{cc}
\hline Concreto Betuminoso Usinado a Quente & $6 \mathrm{~cm}$ \\
\cline { 1 - 2 } Binder & $9 \mathrm{~cm}$ \\
\cline { 1 - 2 } & $25 \mathrm{~cm}$ \\
\hline Sub-base granular & $22 \mathrm{~cm}$ \\
\hline Reforço do subleito & Variável
\end{tabular}

Figura 5.2 - Estrutura do Pavimento existente do km 79+500 ao km 81+500

\subsubsection{Condição do Pavimento}

Para a elaboração do projeto de restauração do segmento foram realizadas avaliações das condições estruturais e funcionais do pavimento.

A Tabela 5.1 apresenta um resumo dos dados deflectométricos obtidos para a faixa externa, mais carregada pelo tráfego, as deflexões foram medidas com espaçamento de $40 \mathrm{~m}$ entre as estações de ensaio.

Tabela 5.1 - Dados de deflexão do Projeto de Restauração (Faixa Externa)

\begin{tabular}{|c|c|c|c|c|}
\hline Km inicial & km final & $\begin{array}{c}\text { Extensão } \\
(\mathbf{m})\end{array}$ & $\begin{array}{c}\text { Deflexão Média } \\
\mathbf{( x 0 , 0 1 m m}\end{array}$ & $\begin{array}{c}\text { Deflexão Característica } \\
\mathbf{( x 0 , 0 1 m m}\end{array}$ \\
\hline $79+500$ & $79+750$ & 250 & 44,3 & 50,1 \\
\hline $79+750$ & $80+000$ & 250 & 43,5 & 52,8 \\
\hline $80+000$ & $81+000$ & 1.000 & 59,5 & 72,7 \\
\hline $81+000$ & $81+500$ & 500 & 49,4 & 59,7 \\
\hline
\end{tabular}


A Figura 5.3 apresenta um perfil com os resultados da avaliação da Irregularidade Longitudinal em termos de QI (cont/km) para todas as faixas de tráfego em Fevereiro de 2002.

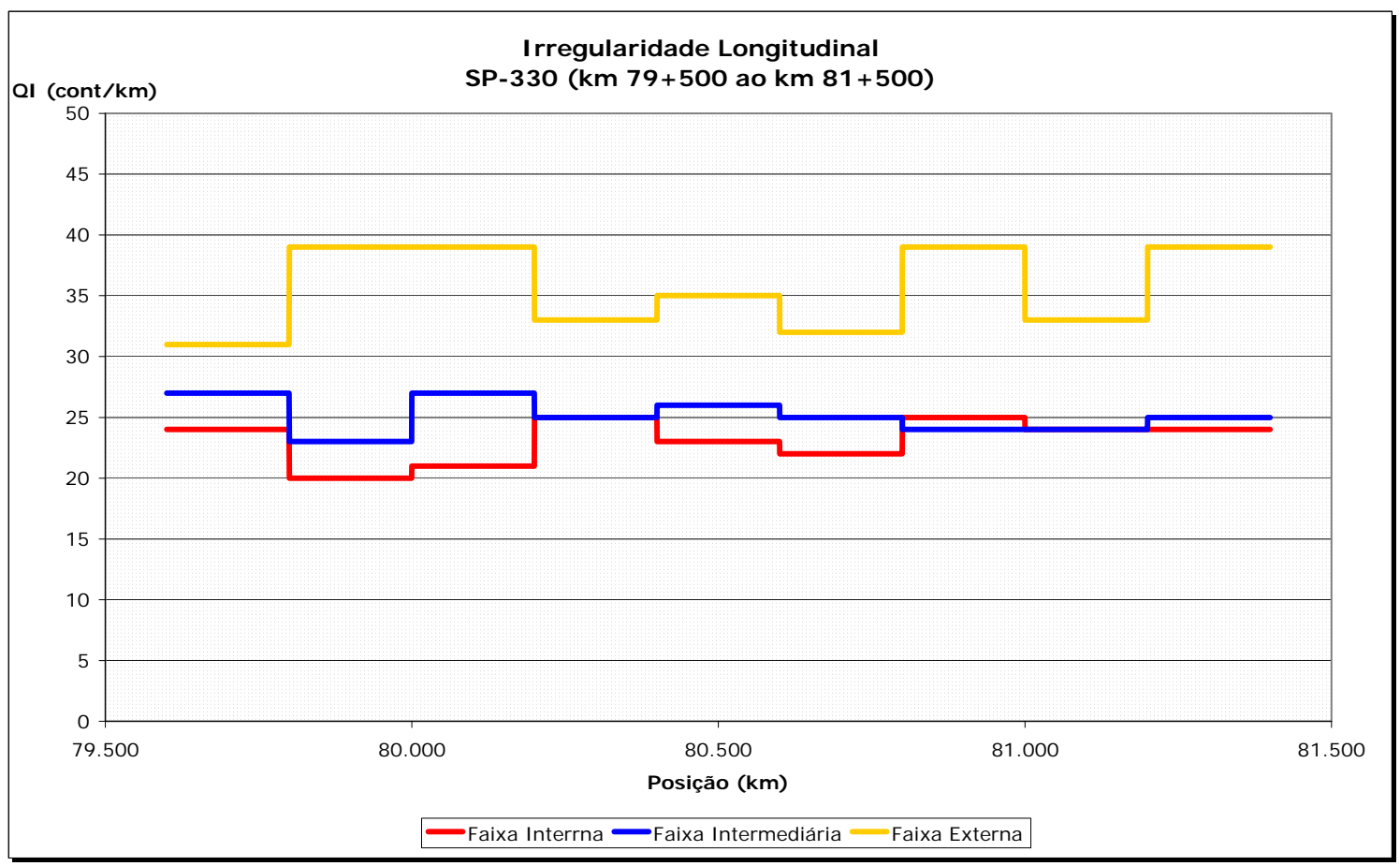

Figura 5.3 - Irregularidade Longitudinal (QI em cont/km) antes da Restauração

A Tabela 5.2 apresenta um resumo de todos os defeitos encontrados no Levantamento Visual Detalhado em Fevereiro de 2002. 
Tabela 5.2 - Resumo dos defeitos cadastrados

\begin{tabular}{|c|c|c|c|c|}
\hline Faixa & Posição Inicial & Tipo de Defeito & $\begin{array}{c}\text { Largura } \\
\text { (m) }\end{array}$ & $\begin{array}{c}\text { Comprimento } \\
\text { (m) }\end{array}$ \\
\hline Externa & $79+580$ & Remendo & 3,6 & 240 \\
\hline Externa & $79+880$ & Trinca do Tipo FC3 & 3,6 & 120 \\
\hline Meio & $79+360$ & Trinca do Tipo FC3 & 3,6 & 200 \\
\hline Externa & $80+000$ & Trinca do Tipo FC3 & 3,6 & 40 \\
\hline Externa & $80+230$ & Trinca do Tipo FC3 & 3,6 & 560 \\
\hline Meio & $80+070$ & Trinca do Tipo FC2 & 2,0 & 7 \\
\hline Meio & $80+140$ & Trinca do Tipo FC2 & 2,0 & 6 \\
\hline Meio & $80+180$ & Trinca do Tipo FC2 & 2,0 & 20 \\
\hline Meio & $80+200$ & Trinca do Tipo FC2 & 3,6 & 10 \\
\hline Meio & $80+240$ & Trinca do Tipo FC2 & 2,0 & 5 \\
\hline Meio & $80+710$ & Trinca do Tipo FC2 & 1,0 & 10 \\
\hline Externa & $81+080$ & Trinca do Tipo FC3 e Exsudação & 3,6 & 360 \\
\hline Externa & $81+584$ & Trinca do Tipo FC3 & 3,6 & 220 \\
\hline Meio & $81+090$ & Trinca do Tipo FC2 & 2,0 & 10 \\
\hline Meio & $81+105$ & Trinca do Tipo FC2 & 2,0 & 3 \\
\hline Meio & $81+140$ & Trinca do Tipo FC2 & 3,6 & 30 \\
\hline Meio & $81+190$ & Trinca do Tipo FC2 & 2,0 & 70 \\
\hline Meio & $81+280$ & Trinca do Tipo FC2 & 3,6 & 10 \\
\hline Meio & $81+300$ & Trinca do Tipo FC2 & 2,0 & 4 \\
\hline Meio & $81+750$ & Trinca do Tipo FC2 & 3,6 & 5 \\
\hline
\end{tabular}




\subsubsection{Tráfego}

O número "N", número equivalente de operações do eixo padrão rodoviário de 8,2 tf, utilizado no projeto de restauração foi baseado nos estudos realizados para a elaboração da Proposta de Concessão.

Para a determinação dos volumes totais de veículos comerciais que trafegariam pelas faixas de projeto dos vários segmentos de tráfego, durante a vida útil prevista, foram considerados os dados obtidos e adotada a seguinte expressão:

$$
V t=365 * V i * \frac{(1+t)^{P}-1}{t}
$$

Onde:

$\mathrm{V}_{\mathrm{t}}=$ volume total acumulado no período, por segmento de tráfego;

$\mathrm{V}_{\mathrm{i}}=$ volume inicial diário no ano $\mathrm{i}$;

$\mathrm{t}=$ taxa de crescimento anual;

$\mathrm{P}=$ período de projeto (10 anos).

As taxas de crescimento anual foram obtidas através da seguinte expressão:

$$
t(\%)=\left[\left(\frac{V}{V i}\right)^{\frac{1}{p}}-1\right]
$$

Onde:

$$
\begin{aligned}
& \mathrm{t}=\text { taxa de crescimento anual; } \\
& \mathrm{V}=\text { volume inicial diário no ano } 2000 \\
& \mathrm{~V}_{\mathrm{i}}=\text { volume inicial diário no ano } \mathrm{i} ; \\
& \mathrm{P}=\text { período de projeto (10 anos). }
\end{aligned}
$$

Os volumes utilizados para o cálculo das taxas foram àqueles obtidos nas planilhas de volumes projetados SAB-CPD (Sistema Anhanguera - Bandeirantes - Companhia Paulista de Desenvolvimento), conforme apresentados na Tabela 5.3 abaixo. 
Tabela 5.3 - VDM do Projeto Original

\begin{tabular}{|c|c|c|c|}
\hline Local & Sentido & $\begin{array}{c}\text { Segmento } \\
\mathbf{k m}\end{array}$ & $\begin{array}{c}\text { VDM - 1996 } \\
\text { (Unidirecional) }\end{array}$ \\
\hline Rodovia Anhanguera & São Paulo - Jundiaí & 59 a 103 & 7.225 \\
\hline
\end{tabular}

Os valores de $\mathrm{V}_{\mathrm{i}}$ adotados para o cálculo do volume total $\mathrm{V}_{\mathrm{t}}$ foram os do Boletim Anual de Estatística da DERSA - 1994 cujos valores encontram-se na Tabela 5.4.

Tabela 5.4 - Dados de Tráfego do Projeto Original

\begin{tabular}{|c|c|c|c|c|c|}
\hline Local & Seg. & Km & $\begin{array}{c}\text { VDM 1994 } \\
\text { (Bidirecional) }\end{array}$ & $\begin{array}{c}\text { \% Veíc. } \\
\text { Comerciais }\end{array}$ & $\mathbf{V}_{\mathbf{i}} \mathbf{1 9 9 4}$ \\
\hline Anhanguera & 8 & 76 a 82 & 13.952 & 35.17 & 3.841 \\
\hline
\end{tabular}

A composição da frota de veículos comerciais em termos de número de eixos originou-se nas contagens efetuadas no pedágio de Valinhos (km 82), na Pista Norte da rodovia.

A distribuição dos diversos tipos de caminhões em função das várias combinações possíveis de eixos simples, tandem duplo e tandem triplo por número de eixos vêm dos dados de pesagem constantes do MD - 9.00.000-P00/001- (DERSA) para a Rodovia dos Bandeirantes.

Também com base nestes relatórios foram determinados os fatores de veículos individuais para os veículos de 2 a 6 eixos, através da metodologia do USACE (U.S. Army Corps of Engineers).

Seguiu-se o cálculo do número $\mathrm{N}$ segundo a metodologia da USACE através da seguinte expressão:

Onde:

$$
\mathrm{N}=\mathrm{V}_{\mathrm{t}} * \mathrm{FV} * \mathrm{D}
$$


$\mathrm{V}_{\mathrm{t}}=$ volume total de veículos comerciais acumulados no período por segmento de tráfego;

$\mathrm{FV}=$ Fator de veículo (USACE), 7,5;

$\mathrm{D}=$ porcentagem do tráfego de veículos comerciais que solicita a faixa mais carregada (Faixa 3 com 70\% dos veículos comerciais).

Como resultado final tem-se um número $\mathrm{N}$ de projeto de 1,9 × $10^{8}$ operações equivalentes do eixo padrão rodoviário para a Rodovia Anhanguera.

\subsubsection{Análise Estrutural}

O projeto de recuperação estrutural do pavimento objetivou a definição das soluções para reforçar a estrutura existente, garantindo sua durabilidade ao longo do período de projeto, face à solicitação prevista do tráfego.

O diagnóstico do comportamento estrutural do pavimento foi realizado através do estudo da deflectometria. As informações das deflexões foram utilizadas no método de dimensionamento Tecnapav, presente na norma rodoviária DNER PRO-269/94.

O método fundamenta-se na comparação entre as deformações solicitantes e as admissíveis pelos materiais, de forma a não ocorrer a "ruptura" dos materiais constituintes.

A necessidade de reforço estrutural, calculada pontualmente, é determinada aplicando-se a norma mencionada, através do cálculo da Deflexão Admissível.

A deflexão admissível é aquela que, imposta ao pavimento, acarretará a ruptura do revestimento betuminoso por processo de fadiga, representada pelo número "N" acumulado e calculada através do seguinte modelo:

$$
\log D_{\text {adm }}=3,148-0,188 \log \mathrm{N}_{\mathrm{p}}
$$

onde: 
$\mathrm{D}_{\mathrm{adm}} \quad$ - Deflexão admissível;

$\mathrm{N}_{\mathrm{p}} \quad$ - Número "N" acumulado de projeto.

Sendo o número N, determinado pelo método da USACE, igual a 1,9 x $10^{8}$ operações equivalentes do eixo padrão rodoviário calculou-se a deflexão admissível para o trecho em questão como sendo $40 \times 10^{-2} \mathrm{~mm}$.

O passo seguinte é o Cálculo da Espessura Efetiva do Revestimento Existente. Conceitualmente, essa espessura representa a condição estrutural da camada betuminosa de revestimento, tendo em vista a estrutura de referência do modelo, quando comparada com uma camada nova em concreto asfáltico (CBUQ).

Deste modo, um pavimento cujo revestimento encontra-se consideravelmente deteriorado (excesso de trincamento), não possui capacidade estrutural compatível com as condições a que foi inicialmente proposto e, por isso, deve ter sua espessura reduzida, para efeito de modelagem estrutural, à semelhança de uma camada nova do mesmo material.

Portanto, a espessura efetiva do revestimento é calculada pela seguinte equação:

$$
h_{e f}=-5,737+\frac{807,961}{D_{c}}+0,972 \cdot I_{1}+4,101 . I_{2}
$$

onde:

$h_{e f} \quad$ - Espessura efetiva de Concreto Asfáltico(cm);

$D_{c} \quad$ - Deflexão característica $\left(\times 10^{-2} \mathrm{~mm}\right)$;

$I_{1}, I_{2}$ - Parâmetros que dependem do tipo de solo.

Os parâmetros $I_{1}, I_{2}$ são determinados em função do tipo de solo existente no subleito, sendo o mesmo classificado conforme mostrado na Tabela 5.5. 
Tabela 5.5 - Tipos de Solo (DNER-PRO 269/94)

\begin{tabular}{|c|c|c|c|}
\hline CBR \% (Índice de & \multicolumn{3}{|c|}{ S\% (Porcentagem de Silte) } \\
\cline { 2 - 4 } Suporte Califórnia) & $\leq 35$ & 35 a 65 & $>65$ \\
\hline$\geq 10$ & I & II & III \\
\hline 6 a 9 & II & II & III \\
2 a 5 & III & III & III \\
\hline
\end{tabular}

Para Subleito do Tipo I, temos: $\quad I_{1}=0 \quad I_{2}=0$

Para Subleito do Tipo II, temos: $\quad I_{1}=1 \quad I_{2}=0$

Para Subleito do Tipo III, temos: $\quad I_{1}=0 \quad I_{2}=1$

Para o projeto em questão o subleito foi considerado como sendo composto por solo do Tipo II e conseqüentemente os parâmetros $I_{1}, I_{2}$ adotados foram 1 e 0 respectivamente.

Cumpre ressaltar que a adoção de valores de espessura efetiva superiores à espessura do revestimento existente buscam atenuar os efeitos das possíveis diferenças entre os módulos de resiliência das estruturas analisadas em comparação com aqueles adotados para a estrutura padrão do modelo.

A equação de definição da espessura de reforço em CBUQ proposta pela norma DNER PRO 269/94 é baseada no conceito de deflexão admissível, ou seja, a espessura de reforço calculada visa reduzir a deflexão medida no pavimento até um nível considerado aceitável, como segue:

$$
H R=-19,015+\frac{238,14}{\sqrt{D_{a d m}}}-1,357 \cdot h_{e f}+1,016 \cdot I_{1}+3,893 \cdot I_{2}
$$

onde:

HR - Espessura de Reforço Calculada (cm);

$D_{a d m}$ - Deflexão Admissível (x $\left.10^{-2} \mathrm{~mm}\right)$;

$h_{e f} \quad$ - Espessura efetiva de Concreto Asfáltico(cm);

$I_{1}, I_{2}$ - Parâmetros que dependem do tipo de solo. 
A Figura 5.4 abaixo apresenta o resultado do dimensionamento realizado pontualmente para a faixa da maior solicitação de tráfego, já que a mesma foi a que apresentou maiores valores de deflexão no ponto de aplicação da carga.

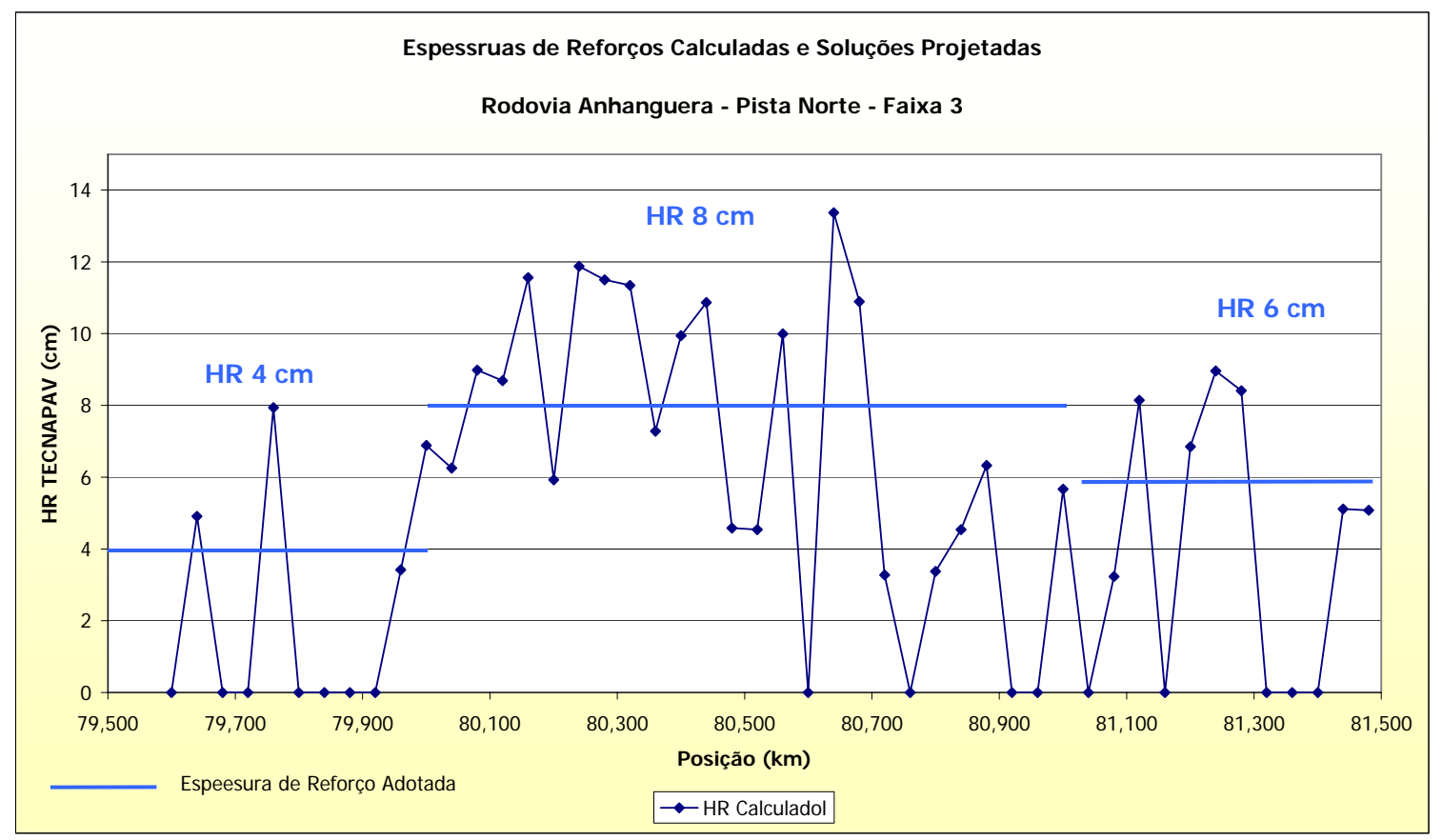

Figura 5.4 - Espessuras de Reforço Dimensionadas

\subsubsection{Análise Funcional}

A irregularidade longitudinal foi avaliada em cada faixa através do Quociente de Irregularidade (QI) e, no presente estudo, objetiva-se atender ao valor exigido pelo Edital de Concessão, que é, para a rodovia principal, de 35 cont $/ \mathrm{km}$.

Tendo em vista as condições do pavimento em questão, dimensionou-se a espessura de concreto asfáltico necessária para a redução do QI para 25 cont $/ \mathrm{km}$, visto que, de acordo com diversos estudos internacionais, esse parâmetro evolui gradualmente ao longo do tempo.

Esse dimensionamento, da espessura de concreto asfáltico necessária para a redução da irregularidade ao patamar proposto, foi realizado pontualmente, com base na 
equação da norma rodoviária denominada DNER-PRO 159/85 - Projeto de Restauração de Pavimentos Semi-rígidos e Flexíveis apresentada:.

$$
H R Q I=\frac{\text { QIantes }-25}{3,612}
$$

onde:

HRQI - Espessura de Reforço Calculada (cm);

QIantes - QI antes da restauração (cont./km);

Os resultados obtidos, por faixa de tráfego, são apresentados na Figura 5.5.

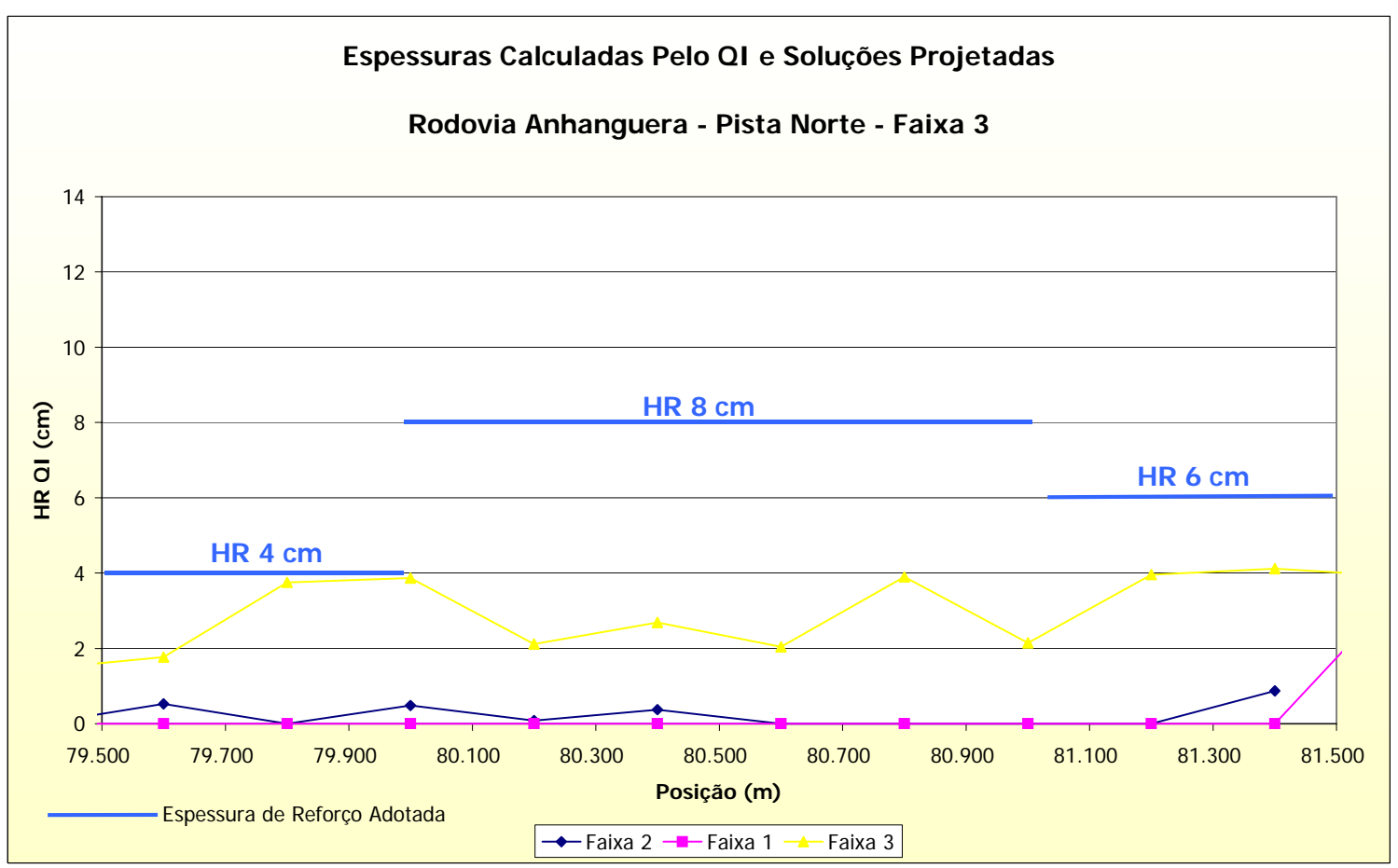

Figura 5.5 - Espessuras de Reforço Calculadas pela Norma DNER-PRO 159/85

\subsubsection{Análise Superficial}

O estudo consistiu na determinação das áreas deterioradas, onde a presença de defeitos é fator de comprometimento da funcionalidade do pavimento, prejudicando a segurança e o conforto ao rolamento do usuário, bem como a preservação da camada sobrejacente a ser executada e a correção de pontos críticos. Assim, para 
cada segmento de projeto, determinou-se a área a reparar, considerando-se a presença de defeitos peculiares aos pavimentos.

Inicialmente, observa-se que a camada de revestimento do pavimento em questão é constituída por camadas de concreto asfáltico com espessura de $15 \mathrm{~cm}$.

Outro parâmetro condicionante à recuperação superficial do pavimento é a determinação de seu estágio atual de deterioração o que pode ser definido a partir dos inventários de superfície realizados.

Dessa forma, partir da observação das fichas de Levantamento Visual Detalhado, propôs-se a execução de reparos ou correções preliminares, pelo processo de fresagem e recomposição, nos trechos em que, de acordo com as informações do LVD, ocorrem defeitos dos tipos "panela", "trincas/jacaré", "remendos" e/ou "afundamentos plásticos", caracterizados como críticos.

\subsubsection{Soluções de Restauração Adotadas}

A partir das análises estruturais, funcionais e superficais descritas anteriormente traçou-se um panorama das necessidades de conservação, revitalização e restauração ao longo do trecho.

Como resultado direto das análises anteriores, a proposição da solução para restauração dos pavimentos, buscou-se adequar suas condições funcionais e atender os critérios estruturais de desempenho e vida útil.

A solução consistiu em realizar os reparos localizados nas áreas deterioradas identificadas no LVD, através da remoção de 6 a $10 \mathrm{~cm}$ de pavimento e recomposição com concreto asfáltico convencional.

Na seqüência, nos trechos que apresentaram deficiência estrutural e/ou funcional, de acordo com a metodologia anteriormente apresentada, foi executado o reforço em 
concreto asfáltico confeccionado com ligante asfáltico do tipo CAP40 convencional e/ou CAP40 modificado com $1,5 \%$ de polímero do Tipo RET e $0,22 \%$ de Catalisador.

A Figura 5.6 apresenta um diagrama unifilar com as soluções adotadas para os trechos em questão distinguindo as atividades de reparos, fresagens e reforço estrutural.

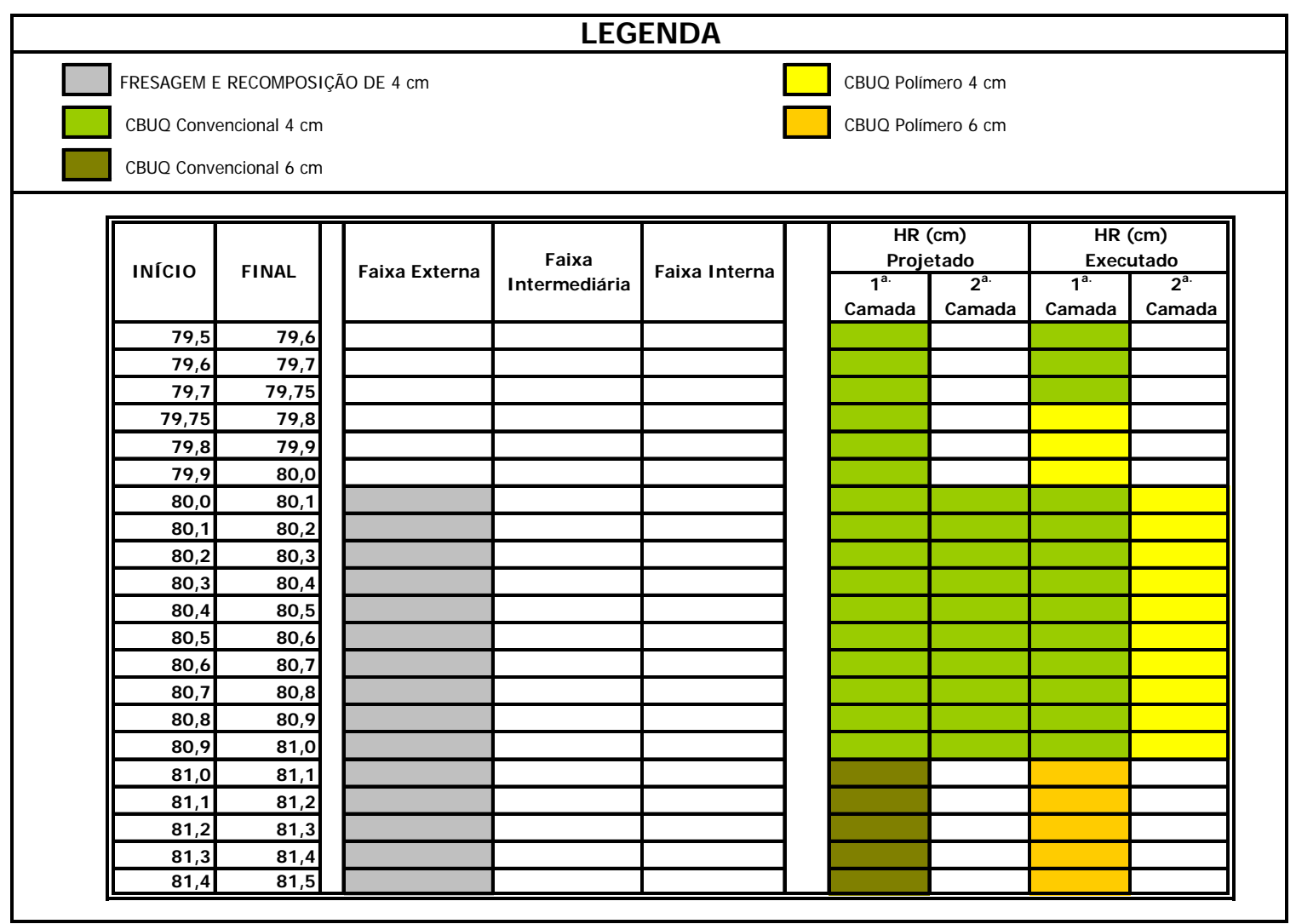

Figura 5.6 - Soluções de Restauração Adotadas

Desta forma o segmento pode ser subdividido em quatro partes, em função da solução de restauração adotada.

1. Do km 79+500 ao km 79+750 (Pista de Referência): Reparos Localizados seguidos de Reforço Estrutural em CBUQ confeccionado com CAP40 convencional na espessura de $4 \mathrm{~cm}$; 
2. Do km 79+750 ao km 80+000 (Comparativo com Trecho de Referência): Reparos Localizados seguidos de Reforço Estrutural em CBUQ confeccionado com CAP40 modificado com 1,5\% de polímero RET e 0,22\% de Catalisador na espessura de $4 \mathrm{~cm}$;

3. Do km 80+000 ao km 81+000 (Segmento com Reforço estrutural calculado de 8cm): Fresagem com Recomposição do revestimento existente na espessura de 4,0cm na faixa externa e aplicação, em toda a plataforma, de Reforço Estrutural em CBUQ confeccionado com CAP40 convencional na espessura de $4 \mathrm{~cm}$ e Reforço Estrutural em CBUQ com 4,0cm confeccionado com CAP40 modificado com $1,5 \%$ de polímero RET e $0,22 \%$ de Catalisador;

4. Do $\mathrm{km} 81+000$ ao $\mathrm{km} \mathrm{81+500} \mathrm{(Segmento} \mathrm{com} \mathrm{Reforço} \mathrm{estrutural} \mathrm{calculado}$ de 6cm): Fresagem com Recomposição do revestimento existente na espessura de $4,0 \mathrm{~cm}$ na faixa externa e aplicação, em toda a plataforma, de Reforço Estrutural em CBUQ com $6,0 \mathrm{~cm}$ confeccionado com CAP40 modificado com $1,5 \%$ de polímero RET e $0,22 \%$ de Catalisador.

\subsection{Projeto da Mistura Aplicada}

Definido o tipo de mistura a ser aplicada (CBUQ na Faixa III DERSA) como solução para a reabilitação do trecho em questão, a partir das características estruturais e funcionais do pavimento, bem como o estudo de tráfego, seguiu-se a elaboração do projeto de mistura pelo método Marshall.

Para o enquadramento na faixa granulométrica foram selecionados materiais pétreos da Pedreira Basalto 6 e cal hidratada, nos teores em peso indicados na Tabela 5.6.

As características das misturas dosadas encontram-se detalhadas na Tabela 5.7, para o teor ótimo determinado pelo método Marshall, para cada um dos ligantes asfálticos em estudo. 
Tabela 5.6 - Composição da Mistura Aplicada

\begin{tabular}{|c|c|c|}
\hline Origem do Material & Material & Porcentagem Seca \\
\hline Pedreira Basalto 6 & BRITA 1 & $20,0 \%$ \\
\hline Pedreira Basalto 6 & PEDRISCO & $17,5 \%$ \\
\hline Pedreira Basalto 6 & PÓ DE PEDRA & $61,0 \%$ \\
\hline Diversos & CAL CH1 & $1,5 \%$ \\
\hline
\end{tabular}

Tabela 5.7 - Características das Misturas Dosadas (Fonte: Consórcio Construban)

\begin{tabular}{|c|c|c|}
\hline \multirow[b]{2}{*}{ ENSAIOS } & \multicolumn{2}{|c|}{ TIPO DE LIGANTE } \\
\hline & CAP40 & $\begin{array}{c}\text { CAP40 + } \\
1,5 \% \mathrm{RET}+ \\
0,22 \% \mathrm{H}_{3} \mathrm{PO}_{4}\end{array}$ \\
\hline Origem do Agregados & Granito & Granito \\
\hline Abrasão Los Angeles (Agregados) & $16 \%$ & $16 \%$ \\
\hline Energia Utilizada (golpes por face) & 75 & 75 \\
\hline Porcentagem de Ligante Adicionado & $5,3 \%$ & $5,9 \%$ \\
\hline Porcentagem de Ligante Efetivo & $5,1 \%$ & $5,7 \%$ \\
\hline Absorção de Ligante & $0,2 \%$ & $0,2 \%$ \\
\hline Massa Específica do Ligante & $1,018 \mathrm{~g} / \mathrm{cm}^{3}$ & $1,019 \mathrm{~g} / \mathrm{cm}^{3}$ \\
\hline Diâmetro Máximo Efetivo do Agregado & $17,1 \mathrm{~mm}$ & $17,1 \mathrm{~mm}$ \\
\hline Massa Esp. Efetiva dos Agregados Combinados & $2,725 \mathrm{~g} / \mathrm{cm}^{3}$ & $2,729 \mathrm{~g} / \mathrm{cm}^{3}$ \\
\hline Massa Específica Máxima Teórica ( $0 \%$ de vazios) & $2,503 \mathrm{~g} / \mathrm{cm}^{3}$ & $2,484 \mathrm{~g} / \mathrm{cm}^{3}$ \\
\hline Densidade Aparente da Mistura & $2,404 \mathrm{~g} / \mathrm{cm}^{3}$ & $2,387 \mathrm{~g} / \mathrm{cm}^{3}$ \\
\hline Resist. `a Tração por Comp. Diametral $(7 \pm 1 \% \mathrm{VV})$ & $1,2 \mathrm{MPa}$ & $1,6 \mathrm{MPa}$ \\
\hline Porcentagem de Vazios (\%VV) & $3,9 \%$ & $3,9 \%$ \\
\hline Vazios do Agregado Mineral (VAM) & $16,1 \%$ & $17,2 \%$ \\
\hline Relação Betume x Vazios (RBV) & $75,6 \%$ & $77,5 \%$ \\
\hline Estabilidade Marshall & $1.444 \mathrm{kgf}$ & $2.073 \mathrm{kgf}$ \\
\hline Fluência & $15,2 \times 0,01 ”$ & $19,9 \times 0,01 "$ \\
\hline Relação Fíler/Betume & 1,4 & 1,3 \\
\hline Cal hidratada $\mathrm{CH}-1$ (\% da mistura total) & $1,4 \%$ & $1,4 \%$ \\
\hline
\end{tabular}




\subsection{EXECUÇÃO E CONTROLE DE QUALIDAdE DA OBRA}

A execução do trecho experimental esteve a cargo da construtora Andrade Gutierrez, contando com o apoio da DuPont do Brasil S/A no fornecimento e incorporação do polímero no ligante e da Construtora Estrutural na confecção e usinagem das misturas asfálticas.

Os segmentos restaurados foram cuidadosamente preparados, sendo os reparos localizados executados previamente à aplicação do reforço estrutural.

Anteriormente à pintura de ligação, aplicada com emulsão RR-2C, o revestimento existente foi varrido mecanicamente para a remoção de qualquer material que pudesse estar solto sobre a pista.

Os equipamentos utilizados na confecção e aplicação da mistura asfáltica foram os seguintes:

- 01 Carregadeira de Pneus Caterpillar CAT 966;

- 01 Usina Drum mixer Barber Greene - $120 \mathrm{t} / \mathrm{h}$;

- 15 Caminhões Basculantes;

- 01 Acabadora de esteiras VÖGELE;

- 02 Rolos de Pneus Dynapac CP-30;

- 01 Rolo Tandem Dynapac CC-43;

- 01 Rolo Tandem Dynapac CG-11.

O processo de compactação adotado, visando atingir os valores definidos no projeto de mistura, foi o seguinte:

- Camadas de CBUQ de $4 \mathrm{~cm}$ :

o Rolo de Pneus (Pressão entre 100 e 120 psi) - 16 passadas

o Rolo Tandem -4 fechadas sendo 2 vibrando

- Camadas de CBUQ de $6 \mathrm{~cm}$ :

o Rolo de Pneus (Pressão entre 100 e 120 psi) - 18 passadas

o Rolo Tandem -4 fechadas sendo 2 vibrando 
As Figuras 5.7 e 5.8 mostram o processo de compactação do trecho.

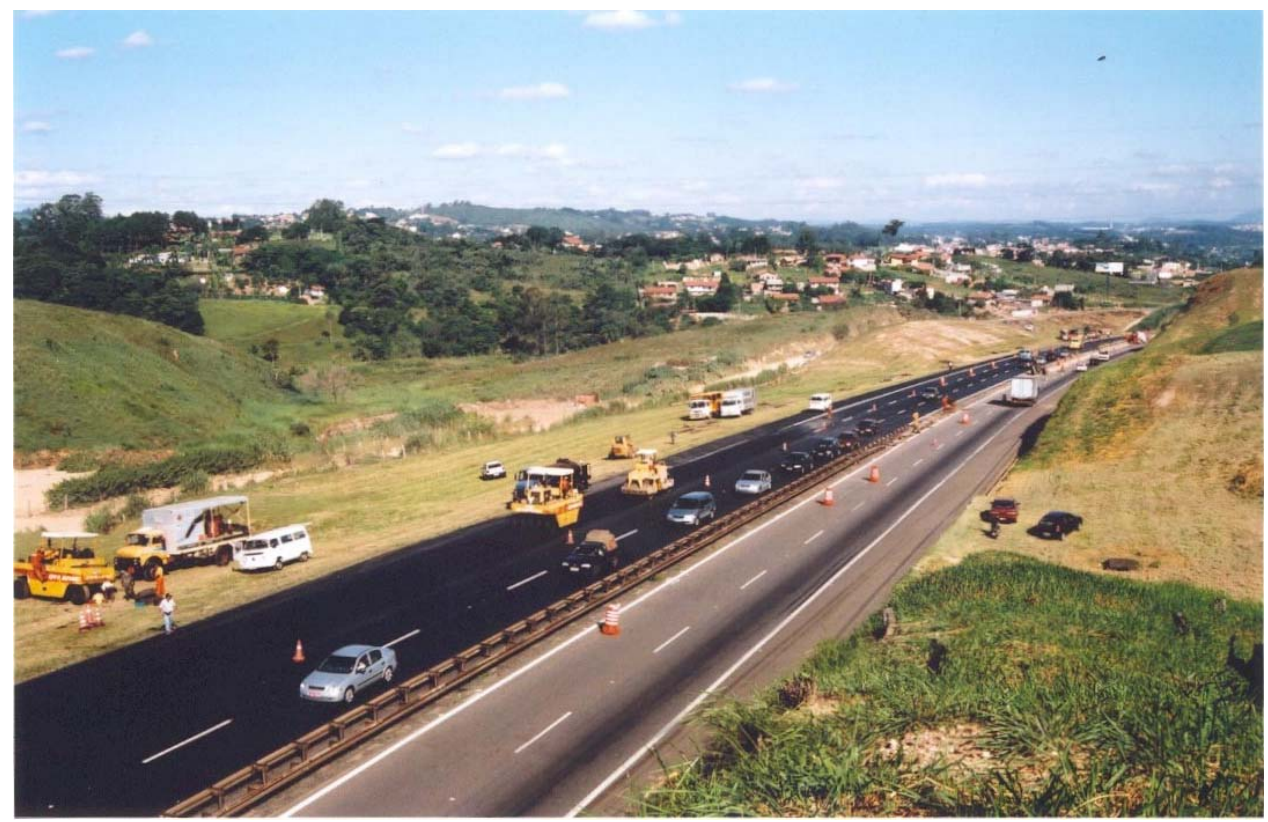

Figura 5.7 - Vista geral do processo de compactação do trecho experimental

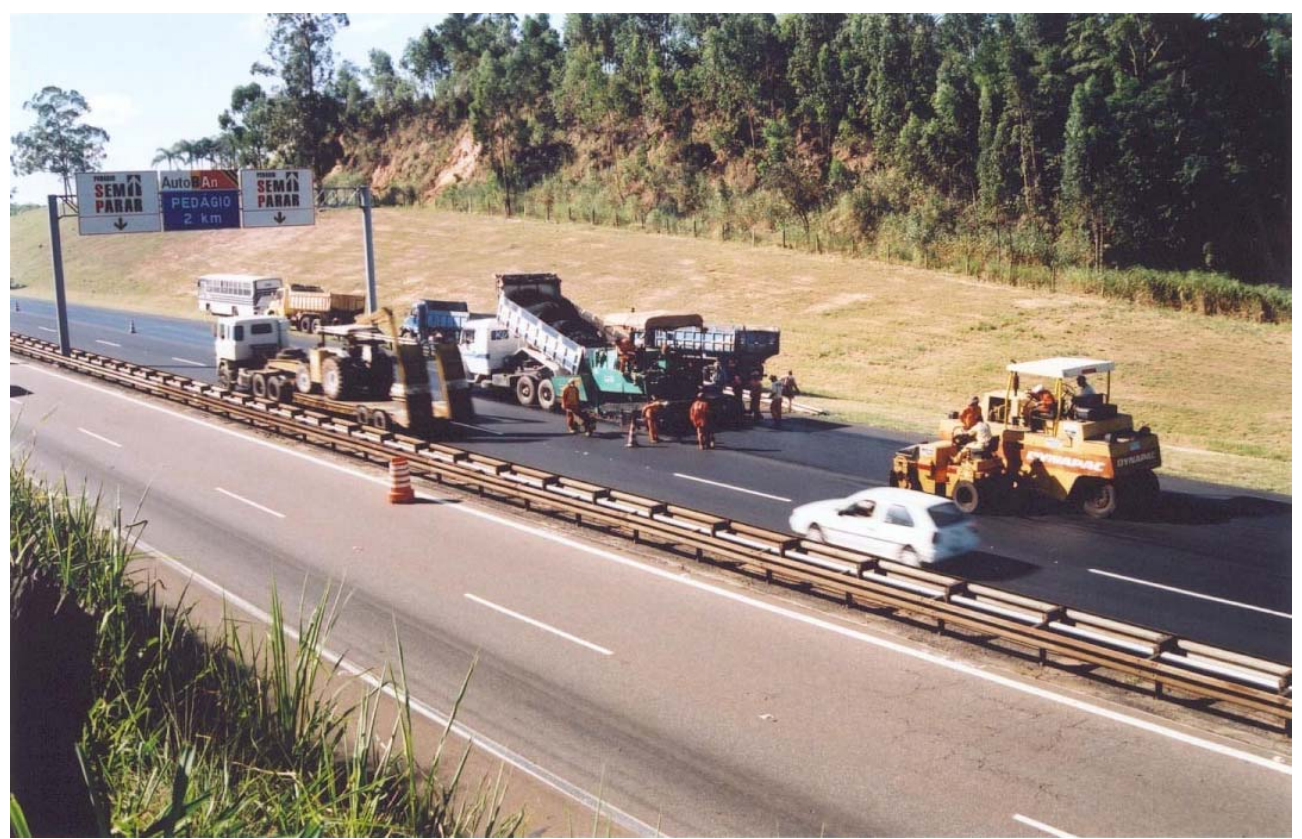

Figura 5.8 - Trecho Experimental sendo executado

A Figura 5.9 mostra a aplicação do Concreto Asfáltico com asfalto modificado por polímero RET. 


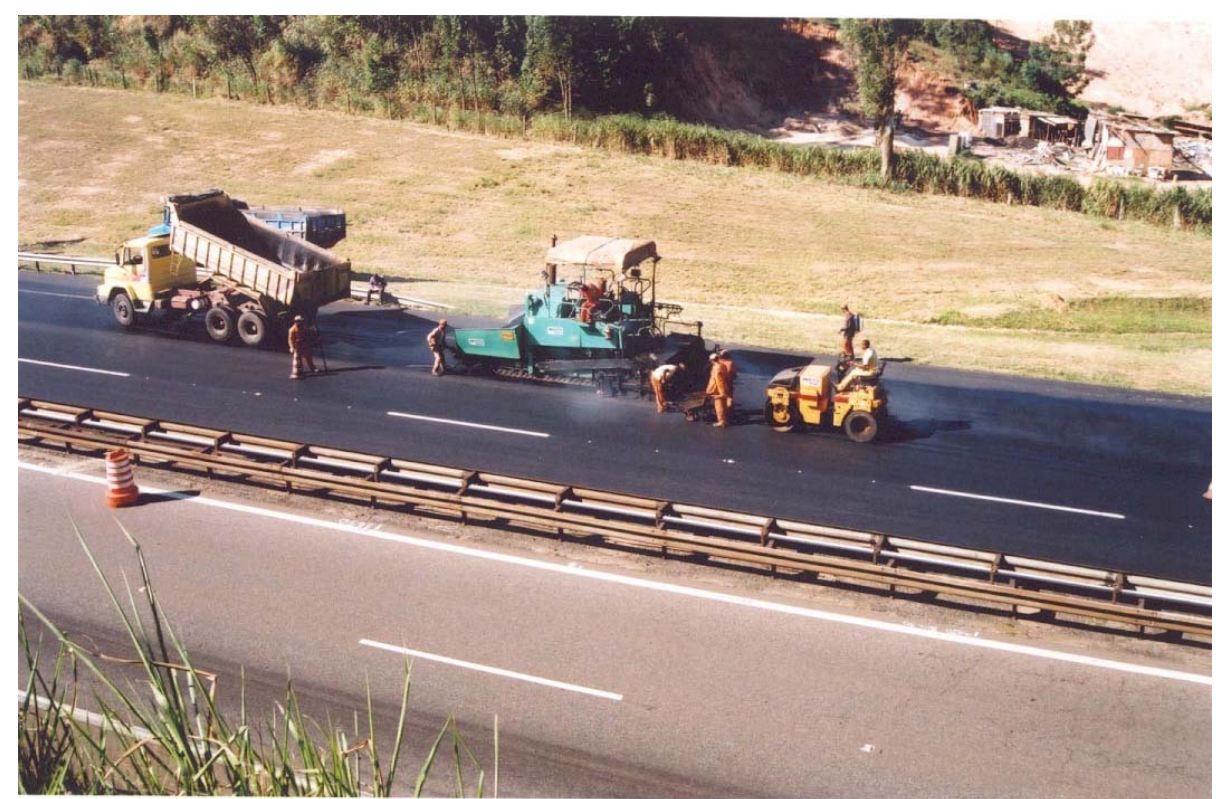

Figura 5.9 - Aplicação do Concreto Asfáltico com Asfalto Modificado por Polímero RET

A aplicação da mistura confeccionada com asfalto modificado teve início no dia 21 de março de 2002 no quilômetro 79+750, com todas as faixas executadas no mesmo dia. A temperatura de mistura na usina variou entre $170^{\circ} \mathrm{C}$ e $185^{\circ} \mathrm{C}$ para garantir uma boa compactação na pista. Durante a aplicação, a temperatura de descarga na acabadora sempre foi superior a $165^{\circ} \mathrm{C}$.

A execução do trecho de referência, entre os $\mathrm{km} \mathrm{79,5} \mathrm{e} \mathrm{79,75} \mathrm{foi} \mathrm{realizada} \mathrm{no} \mathrm{dia} 27$ de março de 2002.

Logo após a execução do segmento, foram extraídos Corpos-de-Prova com a utilização de sonda rotativa. A partir destes Corpos de Prova foram determinados as Densidades, o Grau de Compactação, os Volumes de Vazios, a Espessura e o Teor de Ligante da mistura aplicada. As tabelas 5.8 e 5.9 apresentam os resultados encontrados para as misturas aplicadas com CAP40 e com CAP40 modificado com $1,5 \%$ de polímero RET e $0,22 \%$ de Catalisador, respectivamente. 
Tabela 5.8 - Ensaios realizados nos Corpos de Prova (CAP40)

\begin{tabular}{|c|c|c|c|c|c|c|c|c|}
\hline \multirow[b]{2}{*}{$\mathrm{Km}$} & \multirow[b]{2}{*}{ Faixa } & \multicolumn{3}{|c|}{ Densidade (g/cm3) } & \multirow{2}{*}{$\begin{array}{c}\text { Volume } \\
\text { de } \\
\text { Vazios } \\
(\%)\end{array}$} & \multirow{2}{*}{$\begin{array}{l}\text { Esp. } \\
\text { (cm) }\end{array}$} & \multirow{2}{*}{$\begin{array}{c}\text { Teor de } \\
\text { CAP } \\
\text { Usina } \\
(\%)\end{array}$} & \multirow{2}{*}{$\begin{array}{c}\text { Teor de } \\
\text { Projeto } \\
(\%)\end{array}$} \\
\hline & & Pista & Lab. & $\begin{array}{c}\text { Grau de } \\
\text { Compactação } \\
(\%)\end{array}$ & & & & \\
\hline $79+510$ & 1 & 2,325 & 2,404 & 97 & 7,5 & 4,46 & 5,0 & 5,3 \\
\hline $79+600$ & 1 & 2,326 & 2,404 & 97 & 7,5 & 4,50 & 5,0 & 5,3 \\
\hline $79+740$ & 1 & 2,339 & 2,404 & 97 & 7,0 & 4,37 & 5,0 & 5,3 \\
\hline $79+520$ & 2 & 2,332 & 2,404 & 97 & 7,2 & 4,00 & 5,0 & 5,3 \\
\hline $79+610$ & 2 & 2,319 & 2,404 & 96 & 7,8 & 4,52 & 5,0 & 5,3 \\
\hline $79+730$ & 2 & 2,339 & 2,404 & 97 & 7,0 & 4,21 & 5,0 & 5,3 \\
\hline $79+530$ & 3 & 2,353 & 2,404 & 98 & 6,4 & 4,09 & 5,0 & 5,3 \\
\hline $79+520$ & 3 & 2,309 & 2,404 & 96 & 8,2 & 3,79 & 5,0 & 5,3 \\
\hline $79+710$ & 3 & 2,304 & 2,404 & 96 & 8,4 & 4,43 & 5,0 & 5,3 \\
\hline
\end{tabular}

Tabela 5.9 - Ensaios realizados nos Corpos de Prova (CAP40+1,5\%Polímero)

\begin{tabular}{|c|c|c|c|c|c|c|c|c|}
\hline \multirow[b]{2}{*}{$\mathrm{Km}$} & \multirow[b]{2}{*}{ Faixa } & \multicolumn{3}{|c|}{ Densidade (g/cm3) } & \multirow{2}{*}{$\begin{array}{c}\text { Volume } \\
\text { de } \\
\text { Vazios } \\
(\%)\end{array}$} & \multirow[b]{2}{*}{$\begin{array}{l}\text { Esp. } \\
\text { (cm) }\end{array}$} & \multirow{2}{*}{$\begin{array}{c}\text { Teor de } \\
\text { CAP } \\
\text { Usina }(\%)\end{array}$} & \multirow{2}{*}{$\begin{array}{c}\text { Teor de } \\
\text { Projeto } \\
(\%)\end{array}$} \\
\hline & & Pista & Lab. & $\begin{array}{c}\text { Grau de } \\
\text { Compactação } \\
(\%)\end{array}$ & & & & \\
\hline $79+760$ & 1 & 2,387 & 2,387 & 100 & 4,7 & 3,86 & 5,35 & 5,9 \\
\hline $79+830$ & 1 & 2,357 & 2,387 & 99 & 5,9 & 4,37 & 5,35 & 5,9 \\
\hline $79+896$ & 1 & 2,333 & 2,387 & 98 & 6,8 & 4,09 & 5,35 & 5,9 \\
\hline $79+777$ & 2 & 2,397 & 2,387 & 100 & 4,3 & 4,24 & 5,35 & 5,9 \\
\hline $79+847$ & 2 & 2,357 & 2,387 & 99 & 5,9 & 4,50 & 5,35 & 5,9 \\
\hline $79+913$ & 2 & 2,348 & 2,387 & 98 & 6,2 & 4,51 & 5,35 & 5,9 \\
\hline $79+794$ & 3 & 2,352 & 2,387 & 99 & 6,1 & 3,92 & 5,35 & 5,9 \\
\hline $79+862$ & 3 & 2,357 & 2,387 & 99 & 5,9 & 4,01 & 5,35 & 5,9 \\
\hline $79+930$ & 3 & 2,376 & 2,387 & 100 & 5,1 & 3,88 & 5,35 & 5,9 \\
\hline $80+020$ & 1 & 2,408 & 2,387 & 101 & 3,2 & 4,13 & 5,80 & 5,9 \\
\hline $80+100$ & 1 & 2,356 & 2,387 & 99 & 5,3 & 4,00 & 5,80 & 5,9 \\
\hline $80+180$ & 1 & 2,298 & 2,387 & 96 & 7,6 & 3,87 & 5,80 & 5,9 \\
\hline $80+030$ & 2 & 2,423 & 2,387 & 102 & 2,6 & 4,61 & 5,80 & 5,9 \\
\hline
\end{tabular}


Tabela 5.9 (Cont) - Ensaios realizados nos Corpos de Prova (CAP40+1,5\%Polímero)

\begin{tabular}{|c|c|c|c|c|c|c|c|c|}
\hline \multirow[b]{2}{*}{$\mathrm{Km}$} & \multirow[b]{2}{*}{ Faixa } & \multicolumn{3}{|c|}{ Densidade (g/cm3) } & \multirow{2}{*}{$\begin{array}{c}\begin{array}{c}\text { Volume } \\
\text { de } \\
\text { Vazios } \\
(\%)\end{array}\end{array}$} & \multirow[b]{2}{*}{$\begin{array}{l}\text { Esp. } \\
(\mathrm{cm})\end{array}$} & \multirow{2}{*}{$\begin{array}{c}\text { Teor de } \\
\text { CAP } \\
\text { Usina }(\%)\end{array}$} & \multirow{2}{*}{$\begin{array}{l}\text { Teor de } \\
\text { Projeto } \\
\quad(\%)\end{array}$} \\
\hline & & Pista & Lab. & $\begin{array}{c}\text { Grau de } \\
\text { Compactação } \\
(\%)\end{array}$ & & & & \\
\hline $80+110$ & 2 & 2,39 & 2,387 & 100 & 3,9 & 4,65 & 5,80 & 5,9 \\
\hline $80+180$ & 2 & 2,362 & 2,387 & 99 & 5,0 & 4,62 & 5,80 & 5,9 \\
\hline $80+010$ & 3 & 2,354 & 2,387 & 99 & 5,3 & 3,69 & 5,80 & 5,9 \\
\hline $80+100$ & 3 & 2,384 & 2,387 & 100 & 4,1 & 4,05 & 5,80 & 5,9 \\
\hline $80+170$ & 3 & 2,326 & 2,387 & 97 & 6,5 & 4,32 & 5,80 & 5,9 \\
\hline $80+250$ & 1 & 2,307 & 2,387 & 97 & 7,5 & 3,76 & 5,65 & 5,9 \\
\hline $80+400$ & 1 & 2,405 & 2,387 & 101 & 3,5 & 4,56 & 5,65 & 5,9 \\
\hline $80+550$ & 1 & 2,338 & 2,387 & 98 & 6,2 & 3,96 & 5,65 & 5,9 \\
\hline $80+270$ & 2 & 2,389 & 2,387 & 100 & $4,2 \%$ & 4,69 & 5,65 & 5,9 \\
\hline $80+420$ & 2 & 2,339 & 2,387 & 98 & $6,2 \%$ & 4,11 & 5,65 & 5,9 \\
\hline $80+570$ & 2 & 2,405 & 2,387 & 101 & $3,5 \%$ & 4,46 & 5,65 & 5,9 \\
\hline $80+230$ & 3 & 2,383 & 2,387 & 100 & $4,4 \%$ & 4,70 & 5,65 & 5,9 \\
\hline $80+380$ & 3 & 2,37 & 2,387 & 99 & 4,9 & 4,05 & 5,65 & 5,9 \\
\hline $80+530$ & 3 & 2,380 & 2,387 & 100 & 4,5 & 4,63 & 5,65 & 5,9 \\
\hline $80+650$ & 1 & 2,319 & 2,387 & 97 & 6,4 & 4,55 & 6,05 & 5,9 \\
\hline $80+800$ & 1 & 2,398 & 2,387 & 100 & 3,2 & 6,58 & 6,05 & 5,9 \\
\hline $80+950$ & 1 & 2,338 & 2,387 & 98 & 5,6 & 6,76 & 6,05 & 5,9 \\
\hline $80+630$ & 2 & 2,318 & 2,387 & 97 & 6,4 & 4,68 & 6,05 & 5,9 \\
\hline $80+780$ & 2 & 2,377 & 2,387 & 100 & 4,0 & 6,03 & 6,05 & 5,9 \\
\hline $80+930$ & 2 & 2,359 & 2,387 & 99 & 4,8 & 5,95 & 6,05 & 5,9 \\
\hline $80+670$ & 3 & 2,399 & 2,387 & 101 & 3,1 & 4,40 & 6,05 & 5,9 \\
\hline $80+820$ & 3 & 2,415 & 2,387 & 101 & 2,5 & 5,78 & 6,05 & 5,9 \\
\hline $80+960$ & 3 & 2,39 & 2,387 & 100 & 3,5 & 5,99 & 6,05 & 5,9 \\
\hline $80+993$ & 1 & 2,372 & 2,387 & 99 & 3,7 & 5,50 & 6,40 & 5,9 \\
\hline $81+193$ & 1 & 2,419 & 2,387 & 101 & 1,8 & 5,92 & 6,40 & 5,9 \\
\hline $81+260$ & 1 & 2,415 & 2,387 & 101 & 2,0 & 6,17 & 6,40 & 5,9 \\
\hline $80+990$ & 2 & 2,411 & 2,387 & 101 & 2,2 & 6,25 & 6,40 & 5,9 \\
\hline
\end{tabular}


Tabela 5.9 (Cont) - Ensaios realizados nos Corpos de Prova (CAP40+1,5\%Polímero)

\begin{tabular}{|c|c|c|c|c|c|c|c|c|}
\hline \multirow[b]{2}{*}{$\mathrm{Km}$} & \multirow[b]{2}{*}{ Faixa } & \multicolumn{3}{|c|}{ Densidade $(\mathrm{g} / \mathrm{cm} 3)$} & \multirow{2}{*}{$\begin{array}{c}\text { Volume } \\
\text { de } \\
\text { Vazios } \\
(\%)\end{array}$} & \multirow[b]{2}{*}{$\begin{array}{l}\text { Esp. } \\
(\mathrm{cm})\end{array}$} & \multirow{2}{*}{$\begin{array}{c}\text { Teor de } \\
\text { CAP } \\
\text { Usina }(\%)\end{array}$} & \multirow{2}{*}{$\begin{array}{c}\text { Teor de } \\
\text { Projeto } \\
\quad(\%)\end{array}$} \\
\hline & & Pista & Lab. & $\begin{array}{c}\text { Grau de } \\
\text { Compactação } \\
(\%)\end{array}$ & & & & \\
\hline $81+190$ & 2 & 2,383 & 2,387 & 100 & 3,3 & 5,89 & 6,40 & 5,9 \\
\hline $81+257$ & 2 & 2,401 & 2,387 & 101 & 2,6 & 6,14 & 6,40 & 5,9 \\
\hline $80+989$ & 3 & 2,322 & 2,387 & 97 & 5,8 & 6,02 & 6,40 & 5,9 \\
\hline $81+189$ & 3 & 2,363 & 2,387 & 99 & 4,1 & 6,16 & 6,40 & 5,9 \\
\hline $81+260$ & 3 & 2,356 & 2,387 & 99 & 4,4 & 5,49 & 6,40 & 5,9 \\
\hline $81+280$ & 1 & 2,407 & 2,387 & 101 & 2,8 & 6,08 & 6,10 & 5,9 \\
\hline $81+390$ & 1 & 2,383 & 2,387 & 100 & 3,8 & 6,15 & 6,10 & 5,9 \\
\hline $81+480$ & 1 & 2,361 & 2,387 & 99 & 4,6 & 6,11 & 6,10 & 5,9 \\
\hline $81+280$ & 2 & 2,325 & 2,387 & 97 & 6,1 & 6,19 & 6,10 & 5,9 \\
\hline $81+380$ & 2 & 2,357 & 2,387 & 99 & 4,8 & 6,44 & 6,10 & 5,9 \\
\hline $81+485$ & 2 & 2,376 & 2,387 & 100 & 4,0 & 6,17 & 6,10 & 5,9 \\
\hline $81+285$ & 3 & 2,316 & 2,387 & 97 & 6,5 & 5,68 & 6,10 & 5,9 \\
\hline $81+385$ & 3 & 2,341 & 2,387 & 98 & 5,5 & 6,36 & 6,10 & 5,9 \\
\hline $81+480$ & 3 & 2,346 & 2,387 & 98 & 5,3 & 5,65 & 6,10 & 5,9 \\
\hline
\end{tabular}

\subsection{Monitoramento}

Para uma análise objetiva do desempenho da camada aplicada tem sido realizado o monitoramento periódico das condições estruturais, superficiais, funcionais e de segurança do pavimento, através da realização de ensaios não destrutivos in situ.

\subsubsection{Deflectometria}

As Figuras 5.10, 5.11 e 5.12 apresentadas na seqüência mostram as deflexões máximas obtidas na faixa de maior solicitação de tráfego (faixa 3) na avaliação com o FWD nas três etapas de levantamento realizadas: A Figura 5.10 mostra os levantamentos de novembro de 2001 e em janeiro de 2002, sendo as duas primeiras 
campanhas antes da execução das obras. A Figura 5.11, a campanha de maio de 2004, mais de dois anos depois da execução da obra e a Figura 5.12, os dados de janeiro de 2006 para verificar a evolução dos níveis defectométricos.

Os dados deflectométricos utilizados para o dimensionamento das espessuras de reforço estrutural foram os levantados em novembro de 2001, época da elaboração do projeto de restauração. O levantamento de janeiro de 2002 foi realizado em decorrência das intensas chuvas que ocorreram no final de 2001. Observa-se, que em termos gerais, houve uma evolução significativa nos níveis deflectométricos, provavelmente decorrentes da saturação das camadas subjacentes, em um curto período de tempo.

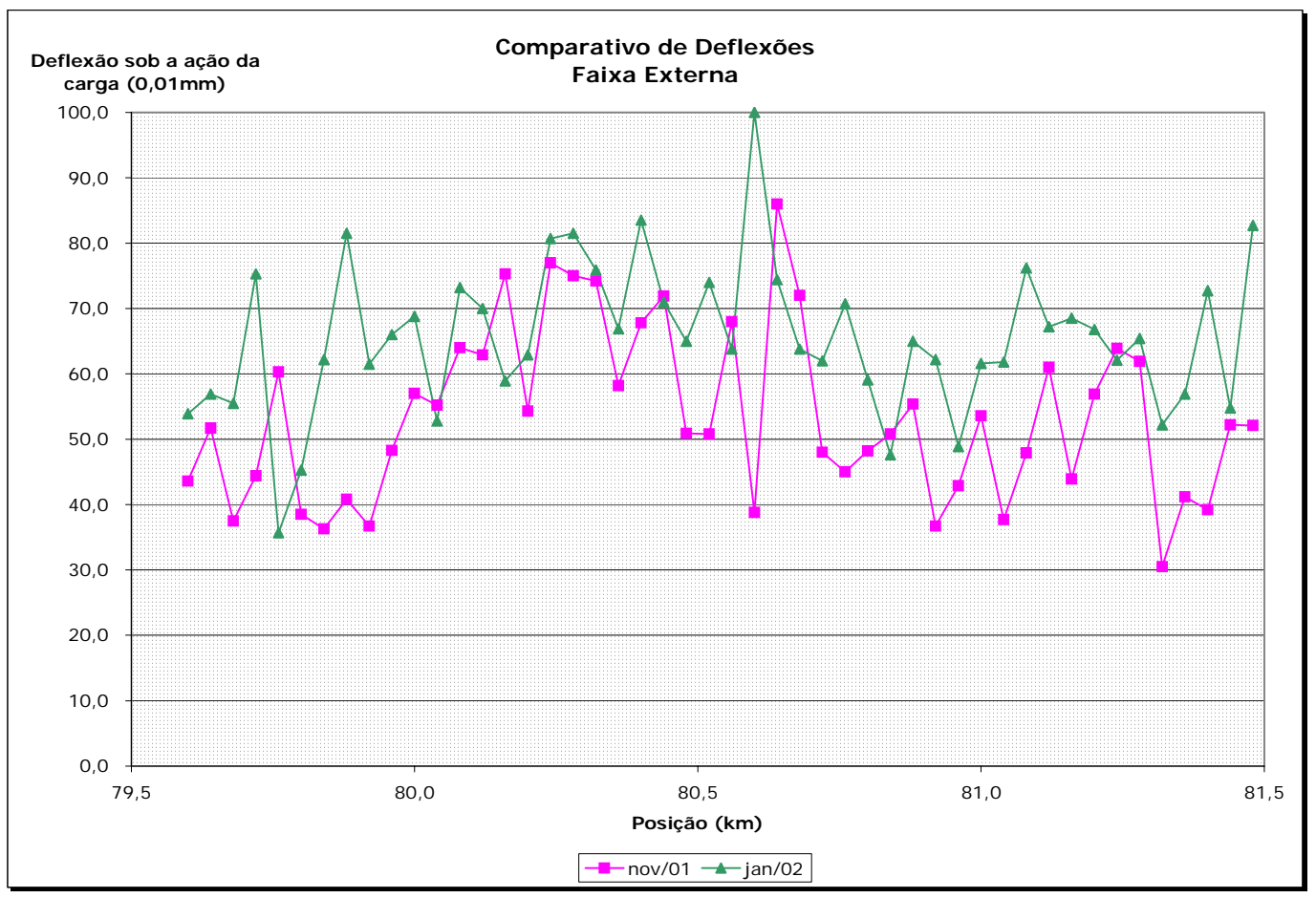

Figura 5.10 - Deflexões medidas antes da Restauração 


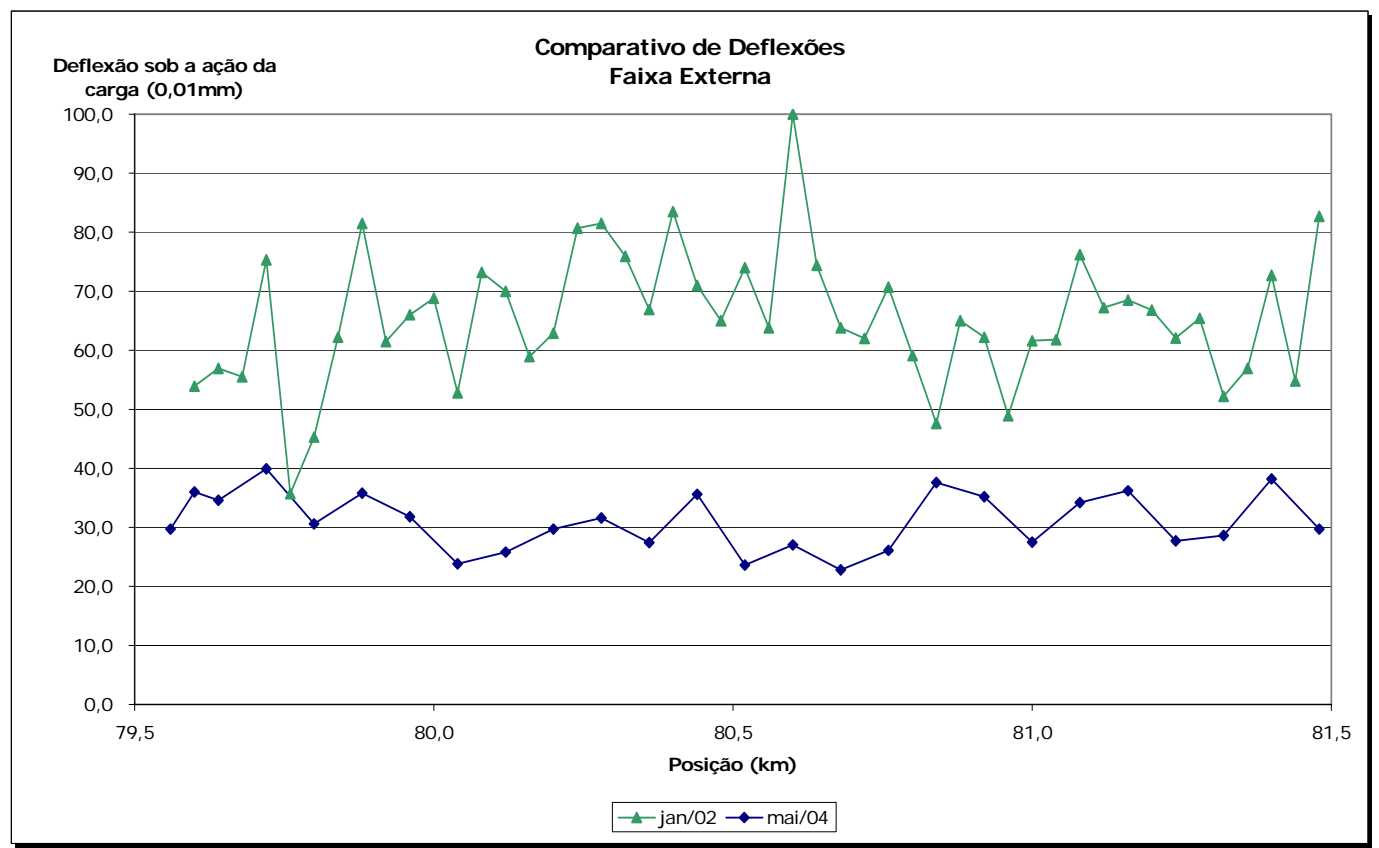

Figura 5.11 - Comparativo entre a Deflexão Medida antes da restauração e após

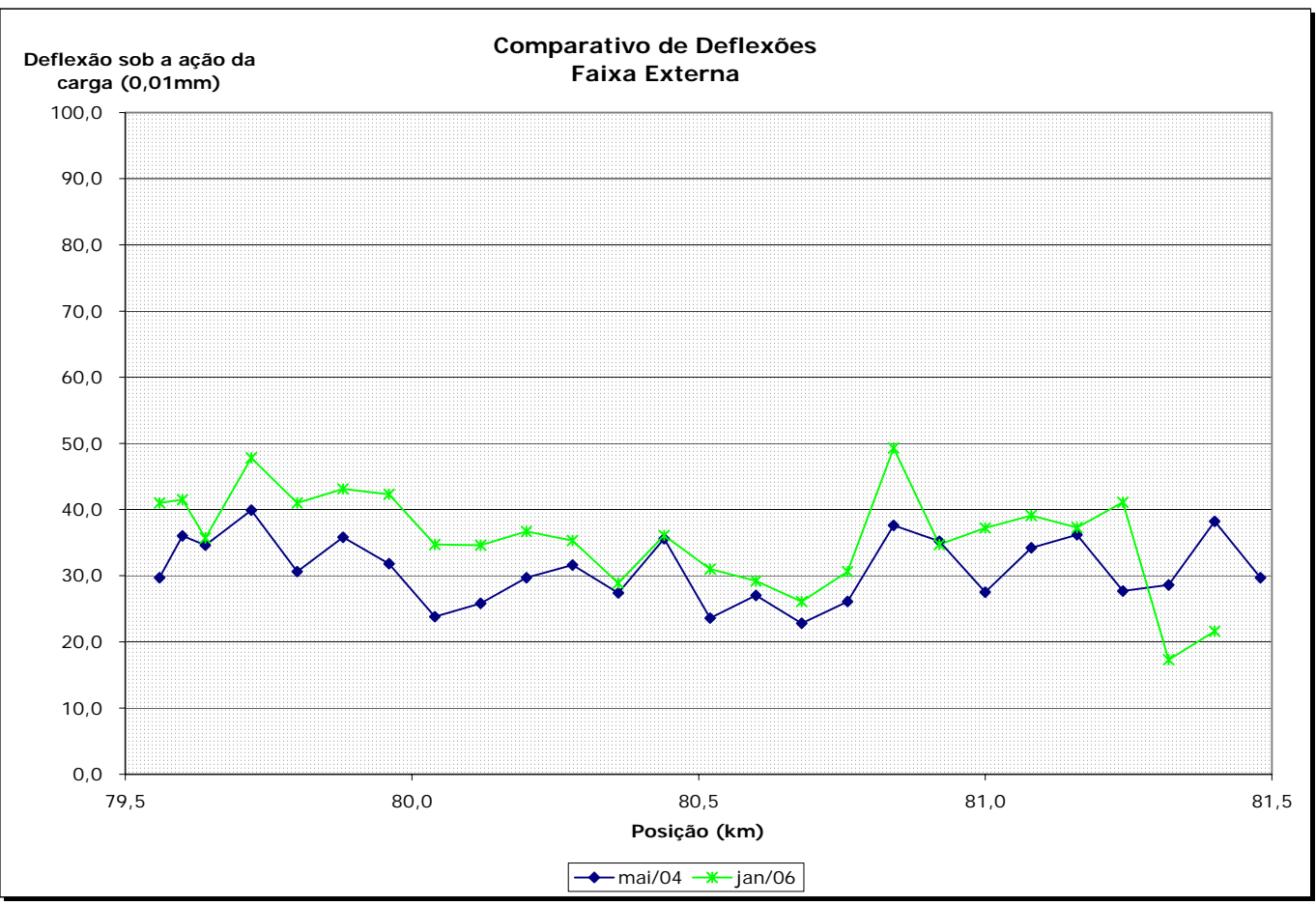

Figura 5.12 - Comparativo - Deflexão Medida em Maio de 2004 e Janeiro de 2006

Verificam-se, através dos resultados obtidos, condições estruturais bastante homogêneas após a execução das obras e níveis deflectométricos compatíveis com o 
nível de tráfego e tipo de estrutura existente após dois anos e meio de solicitação de tráfego, ou seja, as deflexões sob a ação da carga se mostraram inferiores a $40 \times 10^{-2}$ mm após a restauração.

A tabela 5.10 apresenta o resumo dos resultados médios e característicos (média acrescida de um desvio padrão) obtidos em cada campanha de monitoramento em questão.

Tabela 5.10 - Resultados Deflectométricos da SP-330

\begin{tabular}{|c|c|c|c|c|c|c|c|c|c|}
\hline \multirow{3}{*}{$\underset{\text { inicial }}{\mathbf{k m}}$} & \multirow{3}{*}{$\begin{array}{l}\text { Km } \\
\text { final }\end{array}$} & \multicolumn{2}{|c|}{ nov/01 } & \multicolumn{2}{|c|}{ jan/02 } & \multicolumn{2}{|c|}{ mai/04 } & \multicolumn{2}{|c|}{ jan/06 } \\
\hline & & Df1 & Dc & Df1 & Dc & Df1 & Dc & Df1 & Dc \\
\hline & & \multicolumn{8}{|c|}{$(\mathrm{x} 0,01 \mathrm{~mm})$} \\
\hline $79+500$ & $79+750$ & 44,3 & 50,1 & 60,4 & 70,4 & 35,1 & 39,3 & 41,5 & 46,5 \\
\hline $79+750$ & $80+000$ & 43,5 & 52,8 & 60,1 & 75,4 & 32,7 & 35,5 & 42,1 & 43,2 \\
\hline $80+000$ & $81+000$ & 59,5 & 72,7 & 67,8 & 79,3 & 28,7 & 33,6 & 33,9 & 39,8 \\
\hline $81+000$ & $81+500$ & 49,4 & 59,7 & 65,6 & 74,5 & 32,4 & 36,8 & 32,3 & 42,4 \\
\hline
\end{tabular}

Para o caso em questão, observa-se que a redução da deflexão característica nos dois primeiros segmentos, onde a solução de restauração teve a mesma espessura de reforço dimensionada, foi superior entre os quilômetros $79+750$ e $80+000$ onde se utilizou o Ligante Asfáltico modificado por polímero RET (Redução de 44\% na deflexão característica no segmento confeccionado com ligante convencional e de $55 \%$ no segmento confeccionado com ligante modificado por polímero do tipo RET).

Constata-se também que entre maio de 2004 e janeiro de 2006 houve um incremento pouco significativo nos valores deflectométricos de todas as quatro seções, já tendo decorrido quatro anos desde a execução do reforço.

\subsubsection{Irregularidade}


$\mathrm{Na}$ presente pesquisa foram coletados os dados de irregularidade longitudinal disponíveis em estudos realizados no trecho desde 2002 a fim de ilustrar a evolução da condição do pavimento após a execução dos serviços de restauração, conforme listado a seguir:

- Monitoramento da Irregularidade Longitudinal realizado pela Concessionária Autoban em Fevereiro de 2002, anterior à restauração;

- Monitoramento da Irregularidade Longitudinal realizado pela Concessionária Autoban em Março de 2003, um ano após a restauração;

- Monitoramento da Irregularidade Longitudinal realizado pela Concessionária Autoban em Maio de 2004, mais de dois anos após a restauração;

As Figuras 5.13, 5.14 e 5.15 a seguir ilustram o perfil com os três levantamentos realizados. 


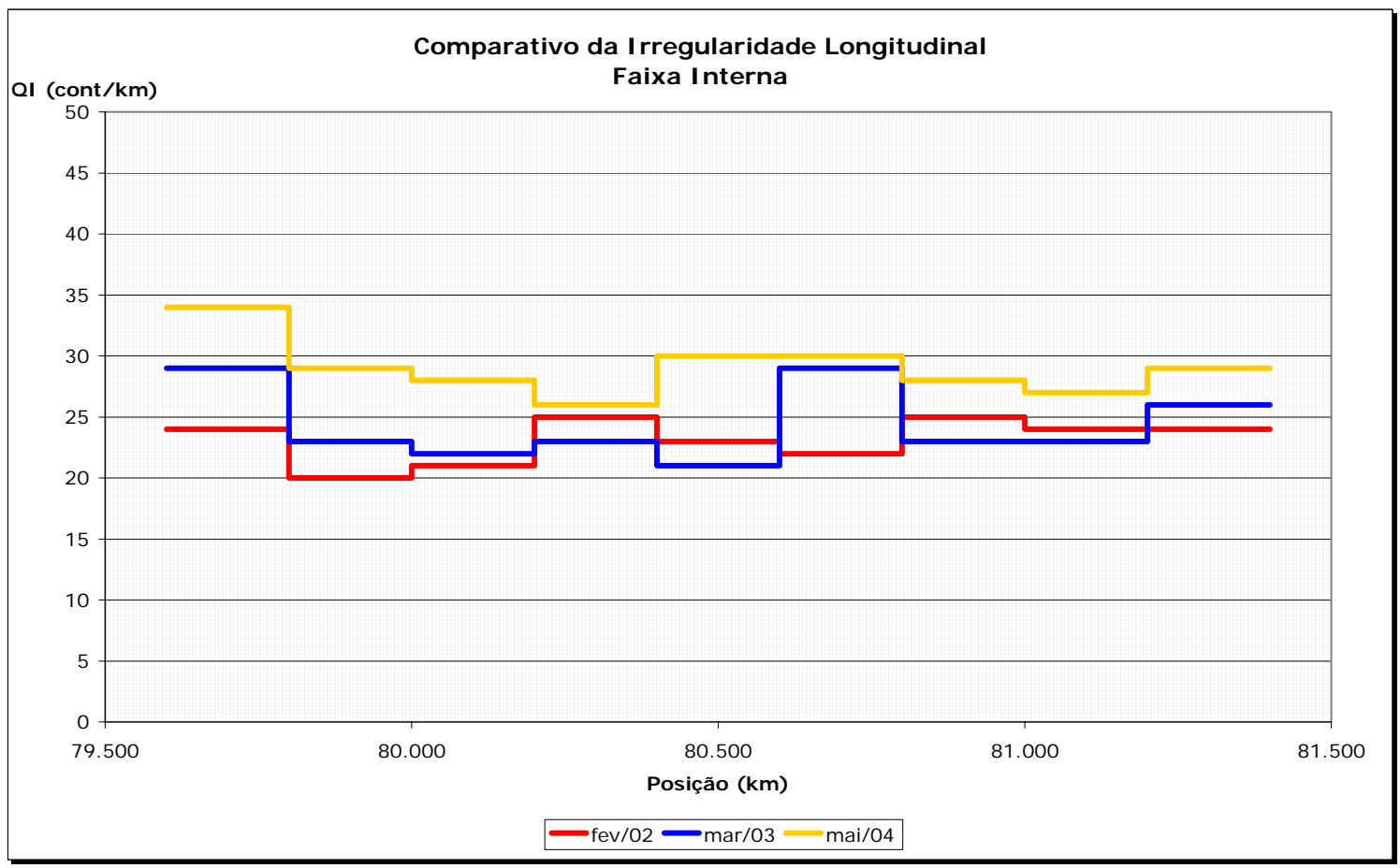

Figura 5.13 - Comparativo das Irregularidades Longitudinais - Faixa. Interna

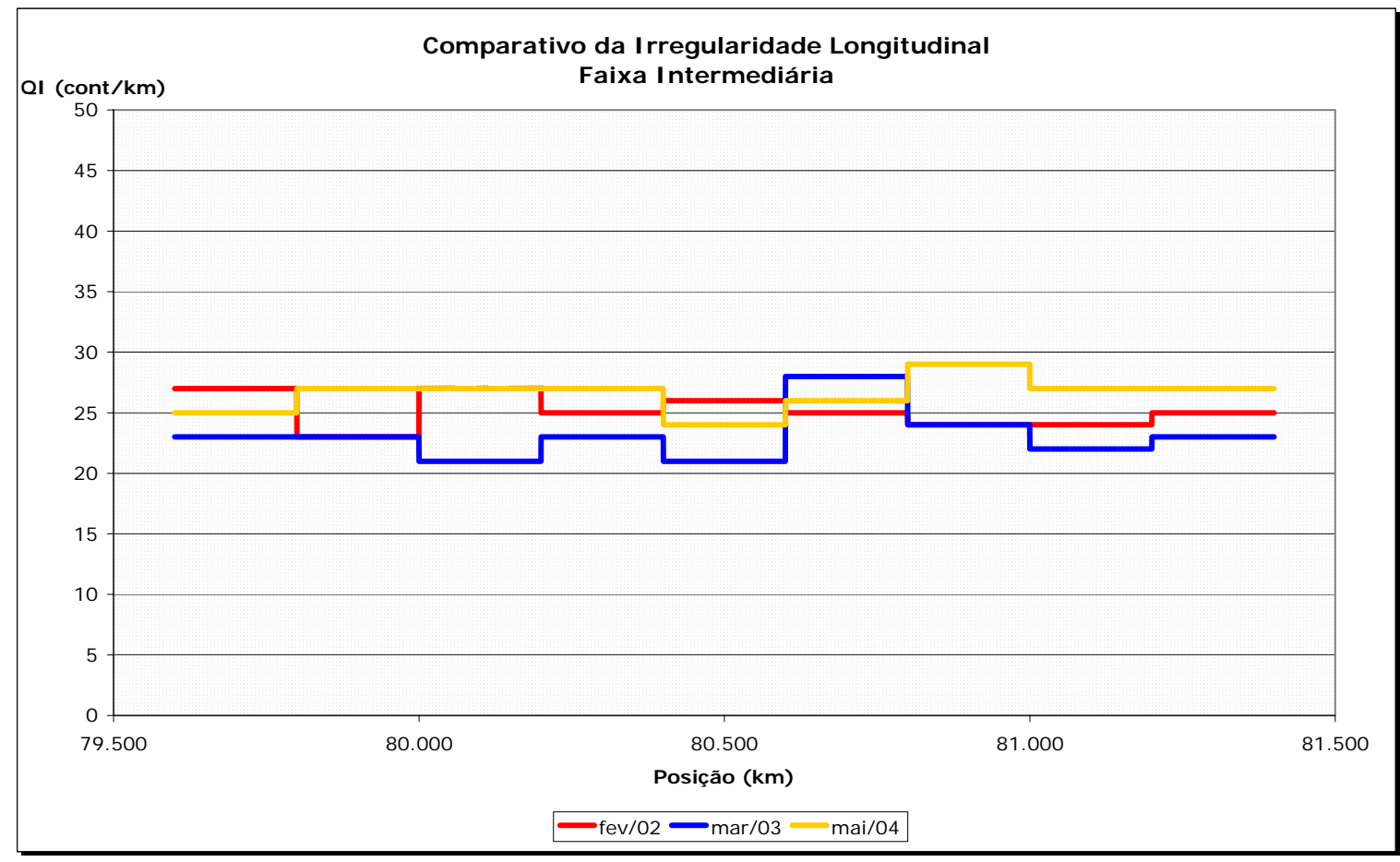

Figura 5.14 - Comparativo das Irregularidades Longitudinais - Faixa.Intermediária 


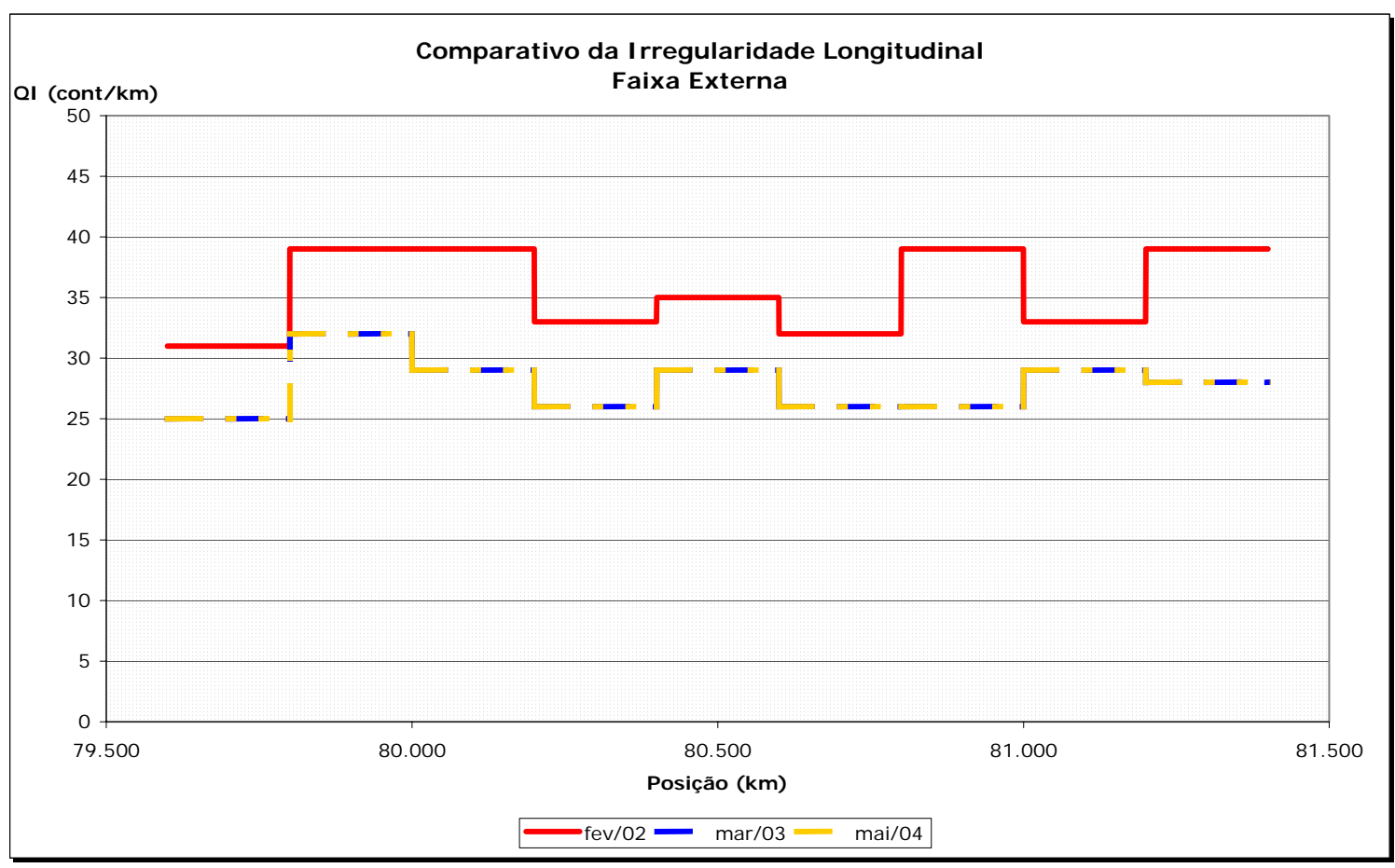

Figura 5.15 - Comparativo das Irregularidades Longitudinais - Faixa Externa

Em termos de Irregularidade Longitudinal observa-se um decréscimo significativo com a restauração da Faixa Externa, observa-se também para esta faixa que os níveis de Irregularidade não sofreram evolução entre as duas últimas campanhas de levantamento.

Nas Faixas Interna e Intermediária os níveis de Irregularidade eram bastante baixos antes mesmo da restauração com valores inferiores a $27 \mathrm{cont} / \mathrm{km}$ na Faixa Intermediária e a $25 \mathrm{cont} / \mathrm{km}$ na faixa Interna. Estes níveis permaneceram baixos após um ano da restauração e sofreram uma elevação na faixa interna após dois anos de restauração.

\subsubsection{Inventário de Superfície}

A fim de se quantificar com maior precisão as áreas deterioradas existentes ao longo da via e, assim, determinar o percentual de cada uma das ocorrências em relação à área total, realizaram-se para o presente estudo, duas campanhas de Levantamento Visual Detalhado (LVD), a primeira em Fevereiro de 2002, antes da restauração e a segunda em Janeiro de 2006, quase quatro anos depois. Tais resultados serão apresentados nas Figuras 5.26 a 5.21 e discutidos adiante. 
Este levantamento tem o objetivo de analisar a condição de superfície dos pavimentos (pista de rolamento e acostamento) de maneira detalhada, sendo realizado por técnicos que locam e caracterizam os defeitos existentes no pavimento da pista e do acostamento em ficha específica, determinando as áreas com presença de trincamentos, remendos, panelas, erosões, afundamentos, etc., ou seja, cadastrando as áreas em que há necessidade de intervenção, subsidiando a definição de soluções de recuperação e manutenção.

Desta forma, uma ficha de campo representa um quilômetro de pista e os defeitos são locados e descritos na tabela abaixo do croqui. 


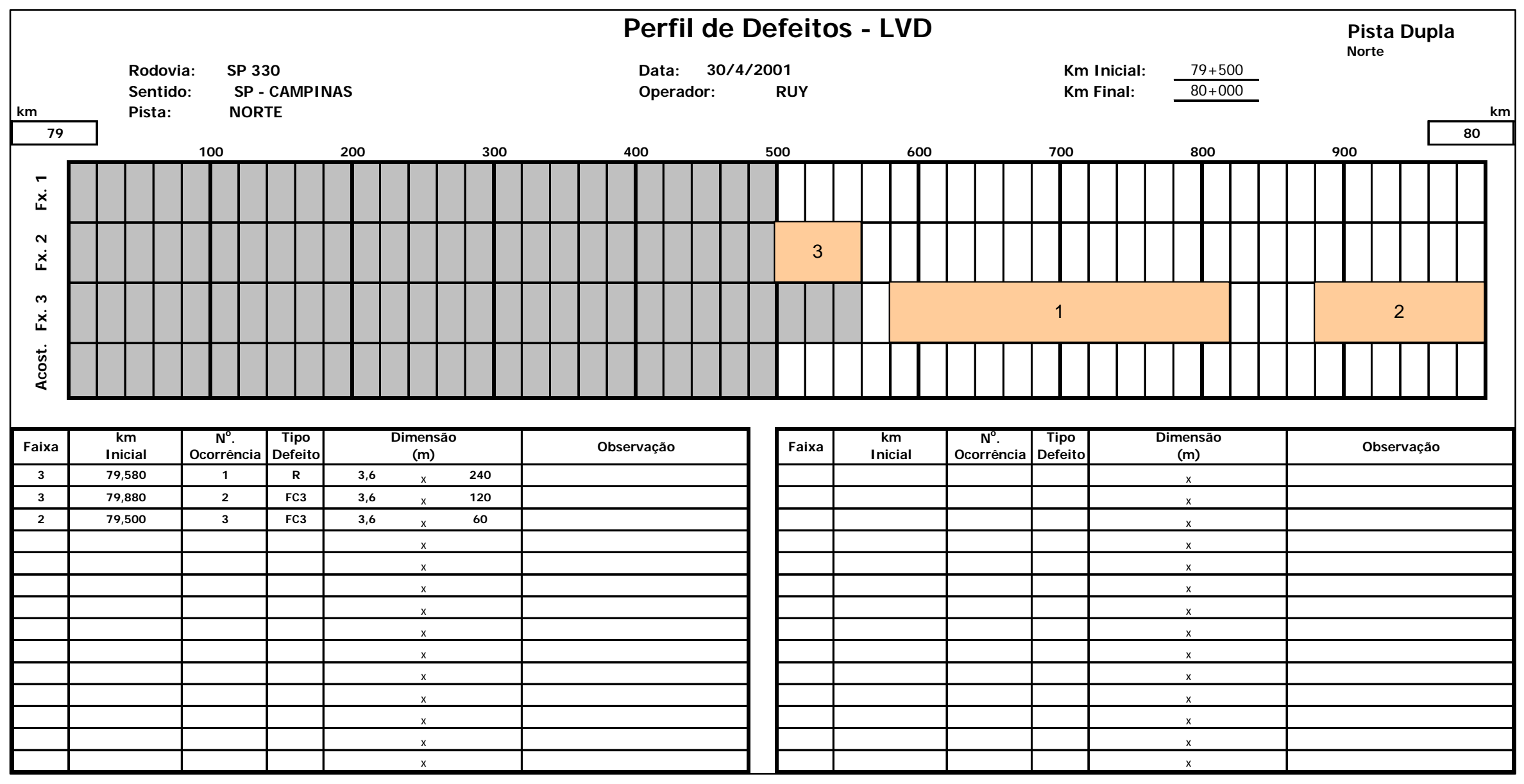

Figura 5.16 - LVD - Fevereiro de $2002-\mathrm{km} \mathrm{79+500} \mathrm{ao} \mathrm{km} \mathrm{80+000}$ 


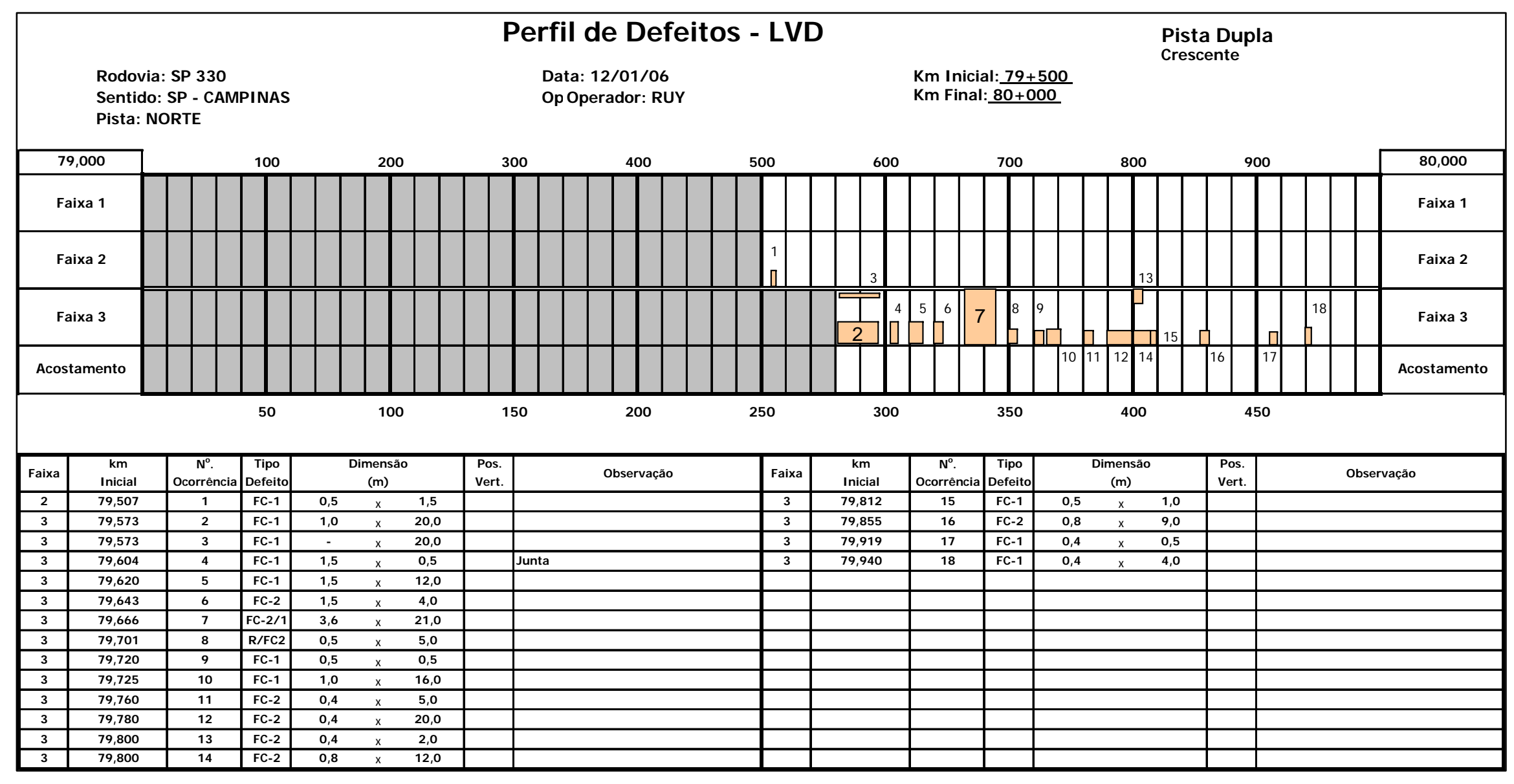

Figura 5.17 - LVD - Janeiro de 2006 - km 79+500 ao km 80+000 


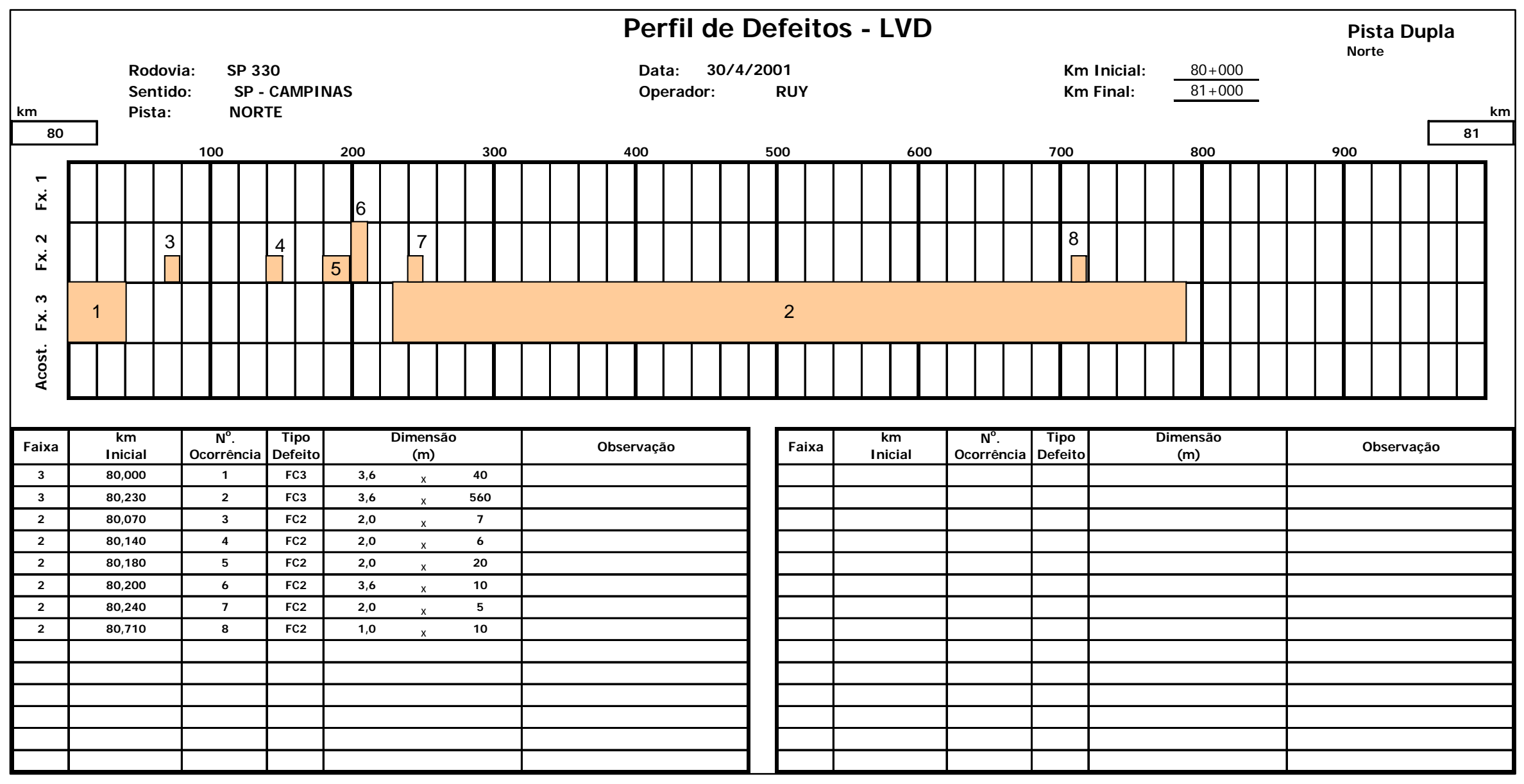

Figura 5.18 - LVD - Fevereiro de 2002 - km 80+000 ao km 81+000 


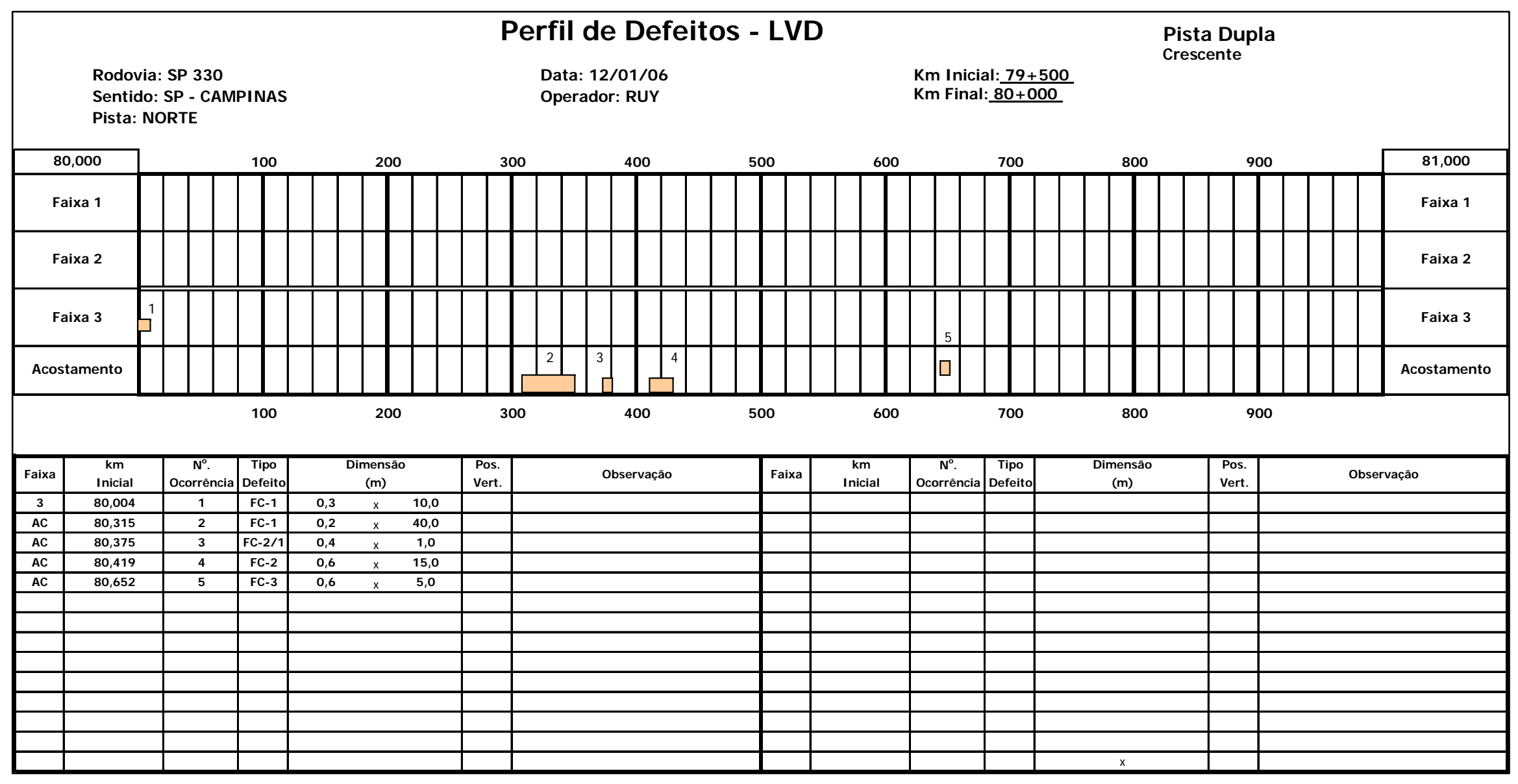

Figura 5.19 - LVD - Janeiro de $2006-\mathrm{km} \mathrm{80+000} \mathrm{ao} \mathrm{km} \mathrm{81+000}$ 


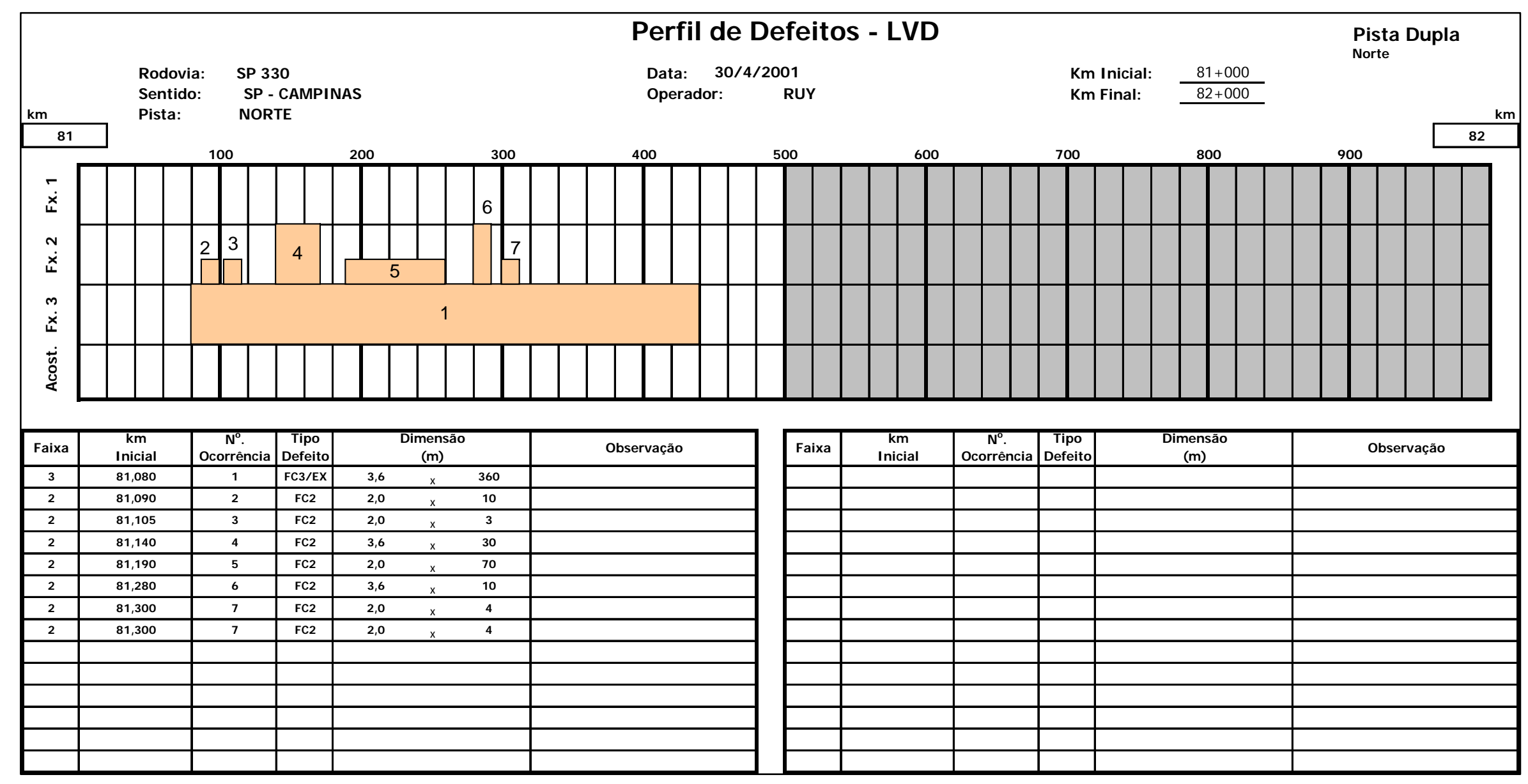

Figura 5.20 - LVD - Fevereiro de $2002-\mathrm{km} 81+000$ ao km 81+500 
Perfil de Defeitos - LVD

Data: 12/ 01/ 06

Operador: RUY
Pista Dupla

Crescente

Rodovia: SP 330

Sentido: SP - CAMPI NAS

Operador: RUY

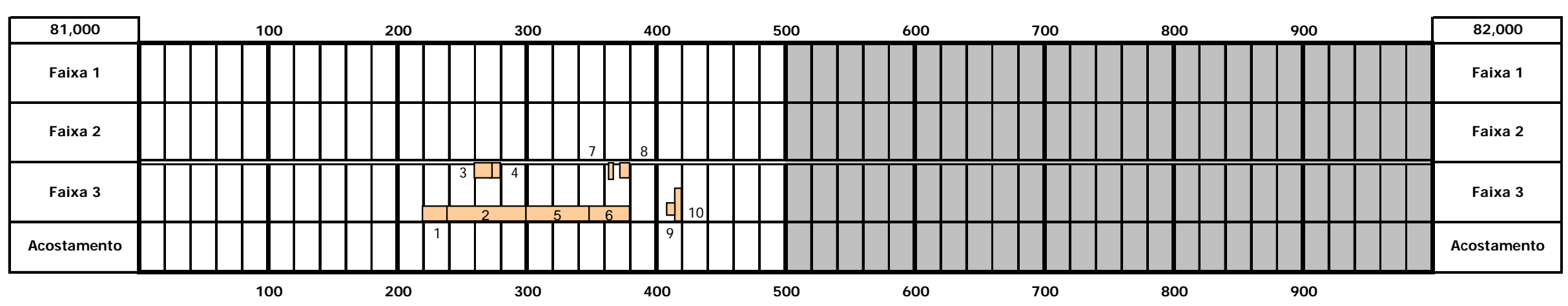

\begin{tabular}{|c|c|c|c|c|c|c|c|c|c|c|c|c|c|c|c|}
\hline \multirow{2}{*}{$\begin{array}{c}\text { Faixa } \\
3\end{array}$} & \multirow{2}{*}{ 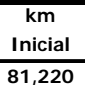 } & \multirow{2}{*}{$\begin{array}{c}\mathrm{N}^{0} . \\
\text { Ocorrência } \\
1\end{array}$} & \multirow{2}{*}{\begin{tabular}{|c|} 
Tipo \\
Defeito \\
FC-2 \\
\end{tabular}} & \multicolumn{3}{|c|}{$\begin{array}{c}\text { Dimensão } \\
(\mathrm{m})\end{array}$} & \multirow[t]{2}{*}{$\begin{array}{l}\text { Pos. } \\
\text { Vert. }\end{array}$} & \multirow[t]{2}{*}{ Observação } & \multirow[t]{2}{*}{ Faixa } & \multirow[t]{2}{*}{$\begin{array}{c}\mathbf{k m} \\
\text { Inicial }\end{array}$} & \multirow[t]{2}{*}{$\begin{array}{c}\mathbf{N}^{0} \\
\text { Ocorrência }\end{array}$} & \multirow[t]{2}{*}{\begin{tabular}{|c|} 
Tipo \\
Defeito
\end{tabular}} & \multirow[t]{2}{*}{$\begin{array}{c}\text { Dimensão } \\
(\mathrm{m})\end{array}$} & \multirow[t]{2}{*}{$\begin{array}{l}\text { Pos. } \\
\text { Vert. }\end{array}$} & \multirow[t]{2}{*}{ Observação } \\
\hline & & & & 1,0 & $\mathrm{x}$ & 15,0 & & & & & & & & & \\
\hline 3 & 81,235 & 2 & $\mathbf{R}$ & 0,8 & $\mathrm{x}$ & 65,0 & & & & & & & & & \\
\hline 3 & 81,260 & 3 & FC-2 & 1,0 & $\mathrm{x}$ & 15,0 & & & & & & & & & \\
\hline 3 & 81,275 & 4 & $\mathbf{R}$ & 0,8 & $\hat{x}$ & 5,0 & & & & & & & & & \\
\hline 3 & 81,300 & 5 & FC-1/2 & 0,8 & $\frac{1}{x}$ & 49,0 & & & & & & & & & \\
\hline 3 & 81,349 & 6 & $\mathbf{R}$ & 0,8 & $\mathrm{x}$ & 27,0 & & & & & & & & & \\
\hline 3 & 81,352 & 7 & FC-1 & 0,5 & $\hat{x}$ & 3,0 & & & & & & & & & \\
\hline 3 & 81,364 & 8 & $\mathbf{R}$ & 0,8 & $\mathrm{x}$ & 11,0 & & & & & & & & & \\
\hline 3 & 81,412 & 9 & $\begin{array}{ll}\text { FC-1 } \\
\end{array}$ & 0,3 & $\frac{\hat{x}}{x}$ & 3,0 & & & & & & & & & \\
\hline 3 & 81,415 & 10 & $\mathbf{R}$ & 1,5 & $\bar{x}$ & 5,0 & & & & & & & & & \\
\hline & & & & & & & & & & & & & & & \\
\hline & & & & & & & & & & & & & & & \\
\hline & & & & & & & & & & & & & & & \\
\hline & & & & & & & & & & & & & & & \\
\hline
\end{tabular}

Figura 5.21 - LVD - Janeiro de $2006-\mathrm{km} 81+000$ ao km 81+500 
A tabela 5.11 apresenta a porcentagem da área trincada dos segmentos 1 e 2 (Trecho de Referência e Comparativo com Trecho de Referência), calculada a partir das fichas de campo do LVD. Ressalta-se que o remendo encontrado no levantamento de 2006 foi considerado como área trincada, já que informações obtidas na Concessionária Autoban confirmaram que este remendo foi executado para correção de um trincamento existente.

Tabela 5.11 - Nível de Trincamento entre 2002 e 2006

\begin{tabular}{|c|c|c|}
\hline ANO & $\begin{array}{c}\text { Km 79+560 ao km 79+750 } \\
\text { (4cm de CBUQ CAP40) }\end{array}$ & $\begin{array}{c}\text { Km 79+750 ao km 80+000 } \\
\text { (4cm de CBUQ CAP40+pol) }\end{array}$ \\
\hline 2002 & - & $48 \%$ \\
\hline 2006 & $20,3 \%$ & $3,7 \%$ \\
\hline
\end{tabular}

Observa-se que o nível de trincamento no Trecho de Referência, executado com ligante do tipo CAP40 convencional é muito superior ao Trecho Comparativo do Trecho de Referência, executado com Ligante do tipo CAP40 modificado com 1,5\% de polímero do tipo RET e $0,22 \%$ de Catalizador em janeiro de 2006. Além disso, os trechos se encontravam em condições diferentes antes da restauração, sendo que cerca de metade do trecho que recebeu recapeamento com asfalto modificado por polímero RET estava trincado, contra um trecho sem trincamento que recebeu na restauração CAP convencional.

\subsubsection{Aderência}

Os Valores de Resistência à Derrapagem (VRD) e de Profundidade Média de Areia (HS), medidos com o Pêndulo Britânico e com o ensaio de Mancha de Areia, respectivamente, em janeiro de 2006, quase quatro anos após a recuperação do segmento, são apresentados na tabela 5.12. 
Tabela 5.12 - Valores de Resistência à Derrapagem (VRD) e de Profundidade Média de Mancha de Areia (HS) de Janeiro de 2006

\begin{tabular}{|c|c|c|c|c|c|}
\hline $\begin{array}{c}\text { Estação de } \\
\text { Ensaio }\end{array}$ & $\begin{array}{c}\text { Posição } \\
\mathbf{( k m )}\end{array}$ & VRD & $\begin{array}{c}\text { Classificação } \\
\text { microtextura }\end{array}$ & $\begin{array}{c}\text { HS } \\
\mathbf{( m m})\end{array}$ & $\begin{array}{c}\text { Classificação } \\
\text { macrotextura }\end{array}$ \\
\hline 01 & $79+700$ & 43 & Insuficientemente Lisa & 0,7 & Média \\
\hline 02 & $79+720$ & 43 & Insuficientemente Lisa & 0,5 & Média \\
\hline 04 & $80+000$ & 43 & Insuficientemente Lisa & 0,6 & Média \\
\hline 05 & $80+200$ & 44 & Insuficientemente Lisa & 0,4 & Média \\
\hline 11 & $80+400$ & 44 & Insuficientemente Lisa & 0,4 & Média \\
\hline 06 & $80+600$ & 45 & Insuficientemente Lisa & 0,5 & Média \\
\hline 08 & $80+800$ & 43 & Insuficientemente Lisa & 0,5 & Média \\
\hline
\end{tabular}

Os valores encontrados para a Resistência à Derrapagem classificaram a superfície do pavimento como Insuficientemente Lisa ou Medianamente Rugosa, sendo os valores encontrados muito próximos ao limite entre as duas classificações. Em termos de Profundidade Média de Mancha de Areia, a classificação da macrotextura para todos os pontos foi como Média. Os valores encontrados para ambos os casos são condizentes com o tipo de mistura asfáltica aplicada na restauração do segmento em questão. 


\section{CONCLUSÕES E RECOMENDAÇÕES}

\subsection{CONCLUSÕES}

\subsubsection{Estudo de Ligantes em Laboratório}

- Houve uma redução no resultado do ensaio de Penetração para asfaltos modificados por polímero RET em comparação aos ligantes convencionais. No CAP 20 , com a adição de $1,0 \%$ de polímero RET, a penetração foi de $60 \times 0,1 \mathrm{~mm}$ (ligante puro) para 49x0,1mm (ligante modificado), nas modificações subseqüentes, com adição de $1,5 \%$ e 2,0\%, a penetração foi para $47 x 0,1 \mathrm{~mm}$ e 42x0,1mm, respectivamente. Para o CAP 40, a adição de 1,0\% de RET não alterou a Penetração, já as modificações com 1,5\% e 2\% representaram uma redução de $32 \times 0,1 \mathrm{~mm}$ para $17 \times 0,1 \mathrm{~mm}$ e $25 \times 0,1 \mathrm{~mm}$, respectivamente;

- Em ambos os asfaltos estudados (CAP 20 e CAP 40), quanto maior o teor de polímero adicionado, maior foi o Ponto de Amolecimento encontrado, parâmetro este, diretamente relacionado à resistência à deformação permanente da mistura, ou seja, quanto maior o Ponto de Amolecimento maior a resistência à deformação permanente;

- O Ponto de Fulgor de qualquer um dos asfaltos estudados é superior a $240^{\circ} \mathrm{C}$, ou seja, todos apresentam características adequadas de segurança em relação ao aquecimento a que este asfalto deve ser submetido em seu manuseio;

- Todos os asfaltos modificados por polímero do tipo RET tiveram uma redução no valor da Ductilidade quando comparados com os asfaltos convencionais. Para o CAP 20, houve uma maior redução desta propriedade quando foi adicionado $1,0 \%$ de polímero. Nas modificações subseqüentes $(1,5 \%$ e $2 \%)$, as reduções foram menores, embora o valor tenha permanecido quase estável. Embora a 
perda de ductilidade possa denotar perda de trabalhabilidade, este resultado aponta que a viscosidade aumentou e que as propriedades reológicas estão alteradas, principalmente de forma positiva, como o retorno elástico: com adição de RET, o ligante passa a ser mais elástico;

- Os ligantes estudados sofreram aumento de sua viscosidade com a adição do polímero RET, principalmente para temperaturas mais baixas. No caso do CAP 20 a viscosidade a $135^{\circ} \mathrm{C}$ passou de $408 \mathrm{cP}$ para $920 \mathrm{cP}$, ou seja, um aumento superior a $100 \%$, com a adição de apenas $1,0 \%$ de polímero. No CAP 40 , com o mesmo $1,0 \%$, o acréscimo foi de quase $90 \%$ com a viscosidade passando de $458 \mathrm{cP}$ para $860 \mathrm{cP}$;

- O Retorno Elástico encontrado para os asfaltos modificados oscilou entre $60 \% \mathrm{e}$ $80 \%$, dependendo da quantidade de polímero e do tipo de asfalto estudado. Estes resultados representam uma melhora no comportamento reológico em relação ao ligante convencional, que apresenta Retorno Elástico desprezível, indicando uma melhora da flexibilidade e da elasticidade dos asfaltos estudados;

- Verifica-se que, mesmo com o aumento do teor de polímero no CAP 40 de 1,5\% para $2,0 \%$ houve uma redução no valor do retorno elástico de $70 \%$ para $65 \%$.Esta redução pode ter ocorrido devido à saturação dos asfaltenos disponíveis para reagir quimicamente com o polímero RET;

- Todos os ligantes estudados apresentaram valores adequados de perda de massa e variação da penetração durante o ensaio, que simula o efeito do calor e do ar no processo de usinagem da mistura asfáltica.

\subsubsection{Estudo de Mistura Asfáltica em Laboratório}

- Houve um acréscimo de aproximadamente $15^{\circ} \mathrm{C}$ nas temperaturas de usinagem e compactação, quando comparamos os resultados encontrados para as misturas elaboradas com os asfaltos convencionais àquelas com asfaltos modificados, devido ao aumento da viscosidade por adição do RET e catalisador;

- Os valores de Módulo de Resiliência encontrados para os corpos de prova confeccionados com asfalto convencional são muito próximos daqueles que 
utilizaram os asfaltos convencionais. Isto sugere que o polímero do tipo RET não altera o comportamento da mistura asfáltica em termos de Módulo de Resiliência;

- Nos corpos-de-prova ensaiados, para a mistura com ligante do tipo CAP 20, houve um incremento de quase $30 \%$ no valor da Resistência à Tração à $25^{\circ} \mathrm{C}$, com o valor passando de $12,3 \mathrm{kgf} / \mathrm{cm}^{2}$ no asfalto convencional para $15,8 \mathrm{kgf} / \mathrm{cm}^{2}$ no modificado. Para o CAP40, a Resistência à Tração não foi sensível à modificação e os valores permaneceram praticamente inalterados;

- As misturas confeccionadas com asfalto modificado por polímero do tipo RET apresentaram uma elevada resistência à deformação permanente quando comparadas com as misturas confeccionadas com asfaltos convencionais em ensaio realizado no simulador francês do tipo LPC. Os resultados mostraram que a deformação permanente é praticamente a metade com as misturas com asfalto modificado. Para tráfego pesado, apenas as misturas com asfalto modificado atenderam ao limite das diretrizes européias para deformação permanente.

\subsubsection{Estudo do Trecho Experimental}

- As condições estruturais dos pavimentos do segmento experimental foram bastante homogêneas após a execução das obras de restauração e os níveis deflectométricos ficaram compatíveis com o nível de tráfego e tipo de estrutura existente após dois anos e meio de solicitação de tráfego, ou seja, as deflexões sob a ação da carga se mostraram inferiores a $40 \times 10^{-2} \mathrm{~mm}$ após a restauração;

- Houve redução da deflexão característica nos dois primeiros segmentos executados (do km 79+500 ao km 79+750, e do km 79+750 ao km 80+000), em que a solução de restauração teve a mesma espessura de reforço dimensionada. Entre os quilômetros $79+750$ e $80+000$, onde se utilizou o ligante asfáltico modificado por polímero RET, a deflexão característica caiu de $75,4 \mathrm{~mm}^{-2}$ para $35,4 \mathrm{~mm}^{-2}$ (Redução de 55\%). No segmento do $\mathrm{km} 79+500$ ao $\mathrm{km} 79+750$, confeccionado com ligante convencional, a deflexão característica foi de $70,4 \mathrm{~mm}^{-2}$ para $39,3 \mathrm{~mm}^{-2}$ (Redução de $44 \%$ );

- O nível de trincamento no Trecho de Referência (0\% em 2002 e 20,3\% em 2006), executado com ligante do tipo CAP40 convencional é muito superior ao 
Trecho Comparativo do Trecho de Referência (48\% em 2002 e 3,7\% em 2006), executado com ligante do tipo CAP40 modificado com 1,5\% de polímero do tipo RET e 0,22\% de Catalizador, em janeiro de 2006. Além disso, os trechos se encontravam em condições diferentes antes da restauração, sendo que cerca de metade do trecho que recebeu recapeamento com asfalto modificado por polímero RET estava trincado, contra um trecho sem trincamento que recebeu na restauração CAP convencional.

- Os valores encontrados para a Resistência à Derrapagem classificaram a superfície do pavimento como Insuficientemente Lisa ou Medianamente Rugosa, sendo os valores encontrados muito próximos ao limite entre as duas classificações. Em termos de Profundidade Média de Mancha de Areia, a classificação da macrotextura para todos os pontos foi como Média. Os valores encontrados para ambos os casos são condizentes com o tipo de graduação das misturas asfálticas aplicadas na restauração do segmento em questão.

\subsection{RECOMENDAÇÕES E SUGESTÕES DE CONTINUIDADE DE PESQUISA}

- Pesquisar outros tipos de misturas elaboradas com asfaltos modificados por Polímero de tipo RET como, por exemplo, o SMA Stone Matrix Asphalt e a CPA Camada Porosa de Atrito;

- Complementar o estudo do Trecho Experimental com a remoção de placas e corpos-de-prova através de sondas rotativas para a realização de ensaios laboratoriais nas misturas que já estão sob a ação do Tráfego;

- Dar continuidade ao monitoramento do Trecho Experimental e verificar a evolução das condições de trincamento e irregularidade longitudinal para eventual calibração das constantes k1 a k5 das equações do HDM para os tipos de misturas estudadas;

- Realizar pesquisa com o simulador de trágefo do tipo "Heavy Veicule Simulator" (HVS) para verificar o comportamento da mistura aplicada no trecho experimental de forma acelerada. 
- Estudar a química do asfalto modificado polímero RET para entender o processo de saturação dos asfaltenos para os asfaltos brasileiros; 


\section{REFERÊNCIAS BIBLIOGRÁFICAS}

ABNT NBR 7208 - Associação Brasileira de Normas Técnicas. Materiais Betuminosos para Pavimentação. Rio de Janeiro, 1998

Amaral, S.C., Estudo de Misturas Asfálticas Densas com Agregados do Estado do Pará, Utilizando Asfalto Convencional (CAP 40) e Asfalto Modificado por Polímero SBS (Betuflex 65/60). Tese de Mestrado, USP. São Paulo, 2000

ASTM E 303-93. - Standart Test Method for Measuring Surfacing Frictional Properties Using the British Pendulum Tester, West Conshohocken, 1998

Brulé B. el Laval C. - Etude Experimentale de La Compatibilité de Resin Epoxydes avec lê Bitume, Rapport de Recherche n ${ }^{\circ}$ 40, Paris LCPC, 1974

CNT - Confederação Nacional do Transporte. http://www.cnt.org.br, 2006

Desmazes, C., Lesueur, D., Phillips, M. - A Protocol for Reliable Measurement of Zero-Shear-Viscosity in Order to Evaluate the Anti-Rutting Performance of Binders - In: Proceedings of $2^{\text {nd }}$ Eurasphalt \& Eurobitumie Congress, Vol 1, 0073, p. 203211. Barcelona, 2000

DNER - Departamento Nacional de Estradas de Rodagem. Pesquisa de Asfaltos Modificados por Polímeros - Relatório Final. Ministério dos Transportes. Diretoria de Desenvolvimento Tecnológico. Tomos I, II e III. Brasília, 1998

DNER/IPR - Coletânea de Normas - Asfaltos Modificados por Polímeros. Rio de Janeiro, 1998

DNER-PRO 011/79 - Departamento Nacional de Estradas de Rodagem. Avaliação Estrutural dos Pavimentos Flexíveis. Rio de Janeiro, 1979 
DNER-PRO 159/85 - Departamento Nacional de Estradas de Rodagem. Projeto de Restauração de Pavimentos Flexíveis e Semi-rígidos. Rio de Janeiro, 1985

DNER-PRO 164/94 - Departamento Nacional de Estradas de Rodagem. Calibração e Controle de Sistemas de Medidores de Irregularidade de Superfície de Pavimento (Sistemas Integradores IPR/USP e Maysmeter). Rio de Janeiro, 1994

DNER-PRO 182/94 - Departamento Nacional de Estradas de Rodagem. Medição de Irregularidade de Superfície de Pavimento com Sistemas Integradores IPR/USP e Maysmeter. Rio de Janeiro, 1994

DNER-PRO 269/94 - Departamento Nacional de Estradas de Rodagem. Projeto de Restauração de Pavimentos Flexíveis - TECNAPAV. Rio de Janeiro, 1994

DNER-PRO 273/96 - Departamento Nacional de Estradas de Rodagem. Determinação das Deflexões Utilizando o Deflectômetro de Impacto Tipo "Falling Weight Deflectometer". Rio de Janeiro, 1996

DNIT - Departamento Nacional de Infra-estrutura Terrestre . http://www.dnit.gov.br, 2006

DYNATEST INC. - Dynatest 8000 FWD Test System Owner's Manual Technical Description. Starke, 1995

FHWA - Federal Highway Administration - Understanding the Performance of Modified Asphalt Binders in Mixtures: Evaluation of Moisture Sensitivity - FHWARD-02-029. Washington, 2001

Freiras, F.J.S. - Asfalto Modificado com EVA. Anais da $30^{\mathrm{a}}$ Reunião Anual de Pavimentação, v. 1, p. 61-74. Salvador, 1996 
GEIPOT - Grupo de Estudos para Integração da Política de Transportes . http://www.geipot.gov.br, 2006

Guarçoni, Dilma dos S. - Petróleo, Refino e Fracionamento Químico de Asfalto, DNER. Rio de Janeiro, 1994

Hilde, S. \& Bernard, E. - Fatigue Testing of Bituminous Binders with a Dynamic Shear Rheometer. In: Proceedings of 2nd Eurasphalt \& Eurobitumie Congress, Vol. 1, 209, pp. 827-834. Barcelona, 2000

Hir, Y.H., Anderson, A.D. et al. - Rheological Characterization of Bituminous Binder to Predict Pavement Rutting. In: Proceedings of 6th RILEM Symposium, pp. 117-123. Zurique, 2003

IBP, Informações Básicas sobre Materiais Asfálticos. $7^{\text {a }}$ ed., IBP/Comissão do Asfalto. Rio de Janeiro, 1999

Instituto de Asfalto, Tradução do Manual de Asfalto. Série do Manual no 4 (MS-4). Rio de Janeiro, 1999

Leite, L.F.M., Estudo de Preparo e Caracterização de Asfaltos Modificados por Polímeros. Tese de D.Sc., COPPE/UFRJ. Rio de Janeiro, 1999

Lu, X., Isacsson, U., Ekblad, J. Rheological Properties of SEBS, EVA and EBA Polymer Modified Bitumens. Materials and Structures, V. 32, p. 131-139, 1999

Macêdo, J. A. G. - Interpretação de Ensaios Deflectométricos Para a Avaliação Estrutural de Pavimentos Flexíveis. 1996. 456p. Tese (Doutorado) - Coordenação dos Programas de Pós-graduação de Engenharia, Universidade Federal do Rio de Janeiro. Rio de Janeiro, 1996

Mano, Eloisa B. - Introdução a Polímeros, Edgard Blucher Ltda. São Paulo, 1986 
Ministério dos Transportes - http://www.transportes.com.br ,2006

Motta, L. M. G., Sá, M. F. P., Oliveira, P. M. F., Souza, A. M. O Ensaio de Creep Estático e Dinâmico na Avaliação das Misturas Asfálticas. 30ª Reunião Anual de Pavimentação, p.115-135. Salvador, 1996

Negrão, D. P., Preussler, E. S et al. Asfalto Modificado com o Terpolímero Elastomérico Reativo (RET) - Congresso Ibero-Latinoamericano del Asfalto. San Jose, 2005

Paterson, W. D. O. - The Highway Design and Maintenance Standards Model. Baltimore / London: The World Bank, The Johns Hopkins University Press, 1987

Planche, J. P., Anderson, D.A. et al., Evaluation of Fatigue Properties of Bituminous Binders. In: Proceedings of 6th RILEM Symposium, pp. 111-116. Zurique, 2003

Pinto, S. Estudo do Comportamento à Fadiga de Misturas Betuminosas e Aplicação na Avaliação Estrutural de Pavimentos. Tese de Doutorado - Universidade Federal do Rio de Janeiro UFRJ. Rio de Janeiro, 1991

Pinto, S. Materiais Betuminosos (Conceituação, especificações e utilização). Instituto Militar de Engenharia. Rio de Janeiro, 1998

Ramos C. R., Guarçoni, D. S., Martinho F. G. - Curso de Química de Asfalto - IBP. Rio de Janeiro, 1995

Scullion, T. - Integrating GPR and FWD technologies in pavement evaluation. In: INTERNATION SYMPOSIUM ON NONDESTRUCTIVE TESTING OF PAVEMENTES AND BACKCALCULATION OF MODULI, 3., 1999, USA. Texas Transportation Institute, 1999 
SHRP - SHRP-LTPP Manual for FWD Testing Operational Guideline: V. 1. 0, operational guide, 1989 ( $\mathrm{n}^{\circ}$ SHRP-LTPP-OG 002)

Souza, A. M., Ramos, C. R., Motta, L. M. G., et al., Curso de técnicas de laboratório em ligantes e misturas asfálticas. IBP, Rio de Janeiro, 1995

Vanelstraete, A. \& Teugels, W., Perfomance Evaluation System for Bituminous Binders. In: Proceedings of 6th RILEM Symposium, pp. 81-87. Zurique, 2003

Yen, T. F., Asphaltene/Resin plus Oil Interconversion: an Investigation into Colloidal Model of Asphaltenes. Proceedings of Workshop - The chemical components and structures of asphaltic materials. Roma, 1984. 